UNIVERSIDADE DE SÃO PAULO

ESCOLA DE COMUNICAÇÃO E ARTES

WILLIAN EDUARDO RIGHINI DE SOUZA

SANTA ROSA DE VITERBO: MEDIAÇÕES PARA UMA DISCUSSÃO SOBRE A IDEIA DE PATRIMÔNIO CULTURAL 
WILLIAN EDUARDO RIGHINI DE SOUZA

\section{SANTA ROSA DE VITERBO: MEDIAÇÕES PARA UMA DISCUSSÃO SOBRE A IDEIA DE PATRIMÔNIO CULTURAL}

Dissertação apresentada à Escola de Comunicação e Artes da Universidade de São Paulo para a obtenção do título de Mestre em Ciência da Informação.

Área de Concentração: Cultura e Informação

Orientadora: Prof $f^{\mathrm{a}}$. Dr ${ }^{\mathrm{a}}$. Giulia Crippa 
Autorizo a reprodução e divulgação total ou parcial deste trabalho, por qualquer meio convencional ou eletrônico, para fins de estudo e pesquisa desde que citada a fonte.

\section{Catalogação na publicação Serviço de Biblioteca e Documentação \\ Escola de Comunicações e Artes da Universidade de São Paulo}

Souza, Willian Eduardo Righini de

Santa Rosa de Viterbo : mediações para uma discussão sobre a idéia de patrimônio cultural / Willian Eduardo Righini de Souza - São Paulo : W. E. R. Souza, 2011.

167 p. : il.

Dissertação (Mestrado) - Escola de Comunicações e Artes / Universidade de São Paulo.

Orientador: $\operatorname{Prof}^{\mathrm{a}} \mathrm{Dr}^{\mathrm{a}}$ Giulia Crippa

1. Patrimônio cultural 2. Patrimônio local 3. Memória social 4. Mediação cultural

CDD 21.ed. -363.69 
Nome: SOUZA, Willian Eduardo Righini de

Título: Santa Rosa de Viterbo: mediações para uma discussão sobre a ideia de patrimônio cultural

Dissertação apresentada à Escola de Comunicação e Artes da Universidade de São Paulo para a obtenção do título de Mestre em Ciência da Informação.

Aprovado em:

Banca Examinadora

Prof. Dr. Instituição:

Julgamento: Assinatura:

Prof. Dr. Instituição:

Julgamento: Assinatura:

Prof. Dr. Instituição:

Julgamento: Assinatura: 


\section{AGRADECIMENTOS}

Agradeço à Prof ${ }^{\mathrm{a}}$. Dr ${ }^{\mathrm{a}}$. Giulia Crippa pelos dois anos e meio de diálogo contínuo que permitiram a elaboração desta dissertação. Se não fosse o seu apoio, paciência e disponibilidade, não teríamos conseguido desenvolver uma parceria que tem se mantido desde os tempos da graduação e produzido sempre novos e diferentes resultados.

Agradeço aos membros da banca, Prof ${ }^{\mathrm{a}}$. Dr ${ }^{\mathrm{a}}$. Maria Celeste Mira e Prof. Dr. Marco Antônio de Almeida, pelas observações e sugestões que tanto contribuíram para o desenvolvimento deste trabalho.

Agradeço aos trezes participantes entrevistados, que sempre se mostraram dispostos a colaborar e compartilhar suas experiências e memórias.

Agradeço à minha família e amigos que me acompanharam e me incentivaram ao longo deste período tanto nos momentos de dificuldades como de conquistas. 
Onde o mapa demarca, o relato faz uma travessia. Michel de Certeau 


\section{RESUMO}

SOUZA, Willian Eduardo Righini de. Santa Rosa de Viterbo: mediações para uma discussão sobre a ideia de patrimônio cultural. 2011. 167 f. Dissertação (Mestrado em Ciência da Informação) - Escola de Comunicação e Artes, Universidade de São Paulo, 2011.

Pretende-se analisar a formação e apropriação de patrimônios culturais na cidade de Santa Rosa de Viterbo - SP por meio dos discursos e ações de seus moradores. Observa-se que no Brasil as políticas patrimoniais privilegiaram a escala nacional e os critérios de técnicos e especialistas para definir o que é um patrimônio cultural. Desta forma, questionamos essa abordagem para desenvolver uma reflexão sobre o patrimônio local através dos seus usos pela sociedade. Propomos um modelo de intervenção que destaca as percepções e representações dos habitantes da cidade para definir os bens que são valorizados como símbolos de identidade e memória. A partir da história oral e trabalhos sobre mediação cultural, definimos métodos, como a realização de entrevistas e o retorno do material produzido, para promover uma relação com um grupo de moradores, registrando suas opiniões sobre o município e os bens que eles identificam como culturalmente relevantes. Com as transcrições das entrevistas e revisão bibliográfica, discutimos a história do município, privilegiando seus aspectos culturais e econômicos, e, por meio de quatro exemplos, que foram; a Banda Sinfônica de Santa Rosa, a Semana Universitária Santa-rosense, a Fazenda Amália e a Folia de Reis, analisamos os valores atribuídos a esses bens que nos permite classificá-los como patrimoniais. Como resultado, revisamos a ideia de divisão dos patrimônios em materiais e imateriais por compreendermos que todo bem cultural possui ambos os atributos.

Palavras-chave: Patrimônio cultural. Patrimônio local. Memória social. Mediação cultural. 


\begin{abstract}
SOUZA, Willian Eduardo Righini de. Santa Rosa de Viterbo: mediations for a discussion of the cultural heritage idea. 2011. 167 f. Dissertação (Mestrado em Ciência da Informação) Escola de Comunicação e Artes, Universidade de São Paulo, 2011.

It is intended to analyze the formation and appropriation of cultural heritage in the town of Santa Rosa de Viterbo - SP through the speeches and actions of its residents. It is noted that in Brazil the heritage policies have concentrated on the national scale and in the criteria of technicians and experts to define what a cultural heritage is. Thus, we questioned this approach to develop a reflection on the local heritage through its uses by society. We proposed an intervention model that highlights the perceptions and representations of town residents to define the assets that are valued as symbols of identity and memory. Through oral history and cultural mediation works, we defined methods such as interviews and the return of the material produced to promote a relationship with a group of residents, recording their opinions about the town and the assets that they identify as culturally relevant. With transcripts of interviews and a literature review, we discussed the history of the town, emphasizing its cultural and economic aspects, and through four examples, which were the Symphonic Band of Santa Rosa, Santa Rosa University Week, Amália Farm and Folia de Reis; we analyzed the values assigned to these assets that allow us to classify them as heritage. As a result, we reviewed the idea of division of cultural heritage into material and immaterial because we realized that all assets have both attributes.
\end{abstract}

Keywords: Cultural heritage. Local heritage. Social memory. Cultural mediation. 


\section{LISTA DE FIGURAS}

FIGURA 1: Santa Rosa de Viterbo no Estado de São Paulo.....................................................10

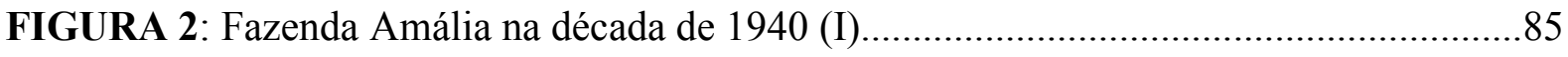

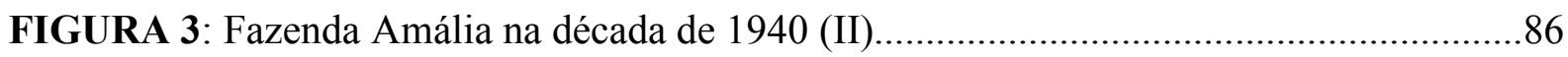

FIGURA 4: Panorama parcial da cidade com a Igreja Matriz ao centro...............................92

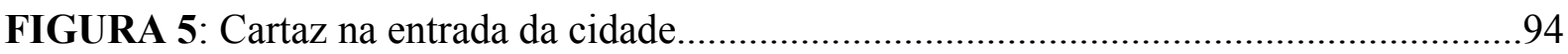

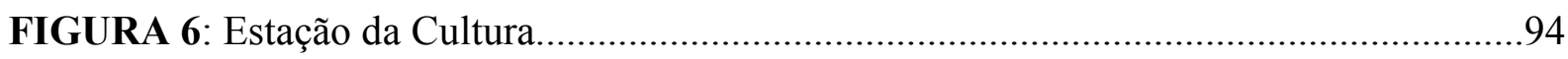

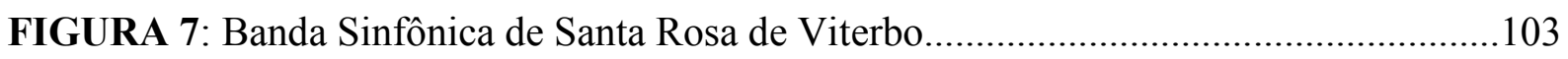

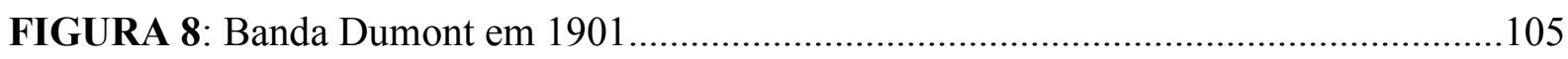

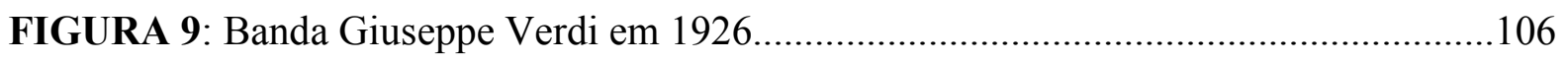

FIGURA 10: Fazenda Amália no início do século XX......................................................117

FIGURA 11: Sede da Fundação Cultural com a inscrição "Posto Policial" na fachada.......129

FIGURA 12: Área externa da sede da Fundação Cultural..................................................129 


\section{SUMÁRIO}

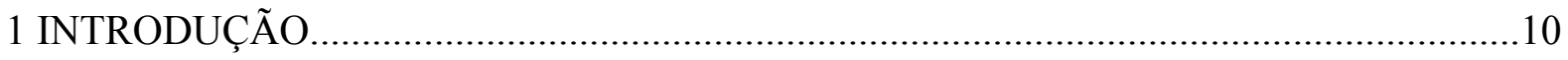

2 O PATRIMÔNIO CULTURAL BRASILEIRO: SUA INVENÇÃO E DESENVOLVIMENTO EM DISCURSOS E AÇÕES....................................................17

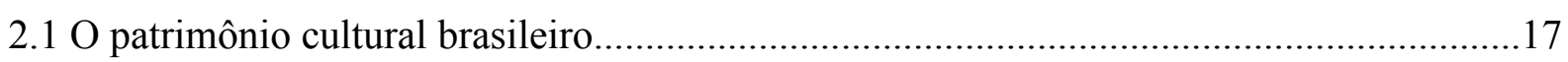

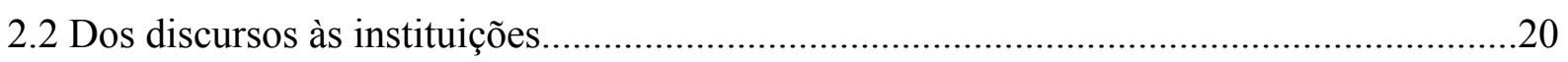

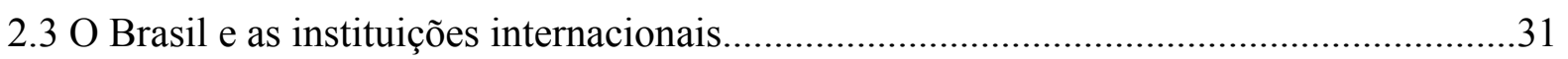

3 A CIDADE COMO LUGAR DE MEMÓRIA: MEDIAÇÕES PARA A APROPRIAÇÃO SIMBÓLICA E O PROTAGONISMO CULTURAL EM SANTA ROSA DE

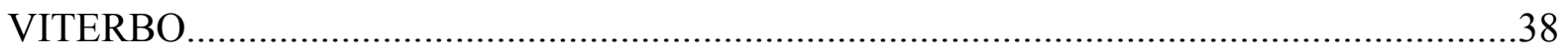

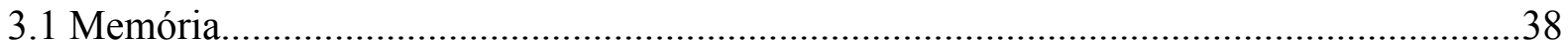

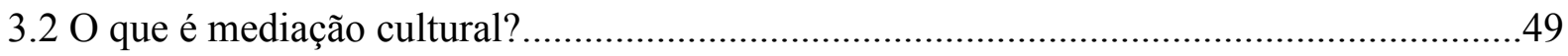

3.3 Um Diálogo entre a Ciência da Informação e a História Oral............................................56

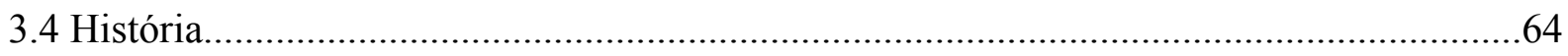

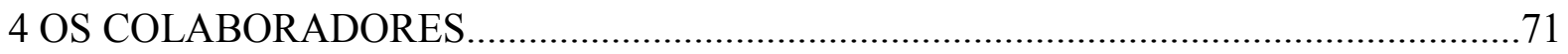

5 MEMÓRIA E HISTÓRIA DOS USOS DA CIDADE E DE SEUS BENS

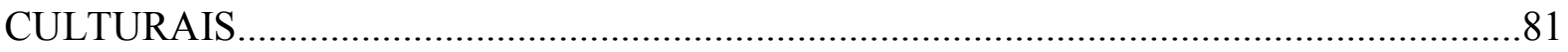

5.1 FAZENDA GRANDE, CIDADE PEQUENA: RELAÇÕES ENTRE ECONOMIA E CULTURA EM UM MUNICÍPIO DO INTERIOR DO ESTADO DE SÃO

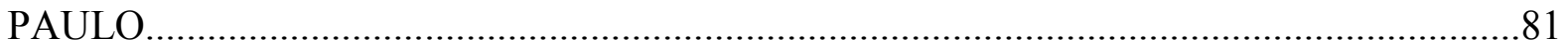

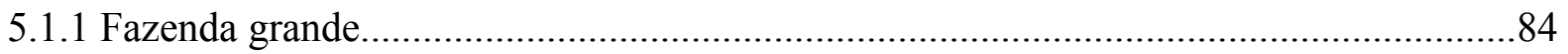

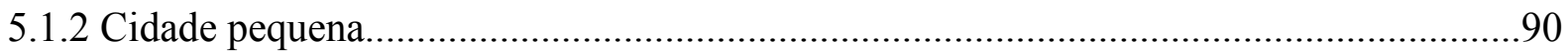

5.2 A CIDADE E SEUS SÍMBOLOS: A FORMAÇÃO DE PATRIMÔNIOS CULTURAIS

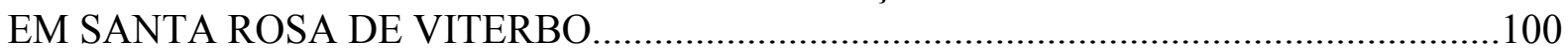

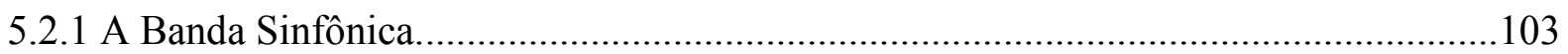

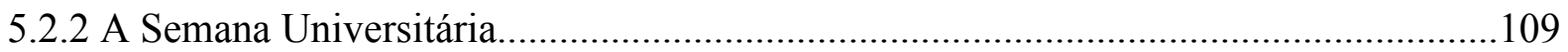

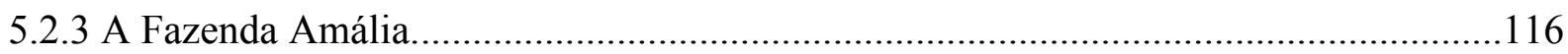

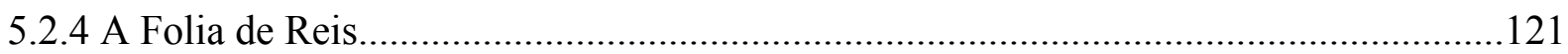

5.2.5 A Banda, a Semana, a Fazenda e a Folia: a junção de valores e sentidos na formação de patrimônios.

6 O PATRIMÔNIO CULTURAL COMO PROCESSO: POR UMA IDEIA QUE SUPERA A OPOSIÇÃO MATERIAL-IMATERIAL ........................................................................... 131

6.1 A ideia de patrimônio. 
7 CONSIDERAÇÕES FINAIS: UM OLHAR SOBRE AS ESCALAS..

144

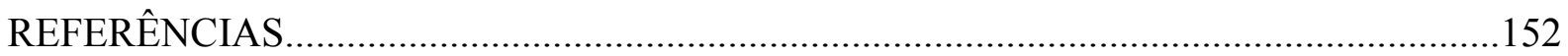




\section{INTRODUÇÃO}

A dissertação a seguir é resultado de um estudo realizado na cidade de Santa Rosa de Viterbo, localizada no nordeste do Estado de São Paulo, a trezentos e dez quilômetros da capital, entre os anos de 2009 a 2011, com o objetivo de analisar a formação e apropriação de patrimônios culturais locais a partir de discursos e práticas sociais.

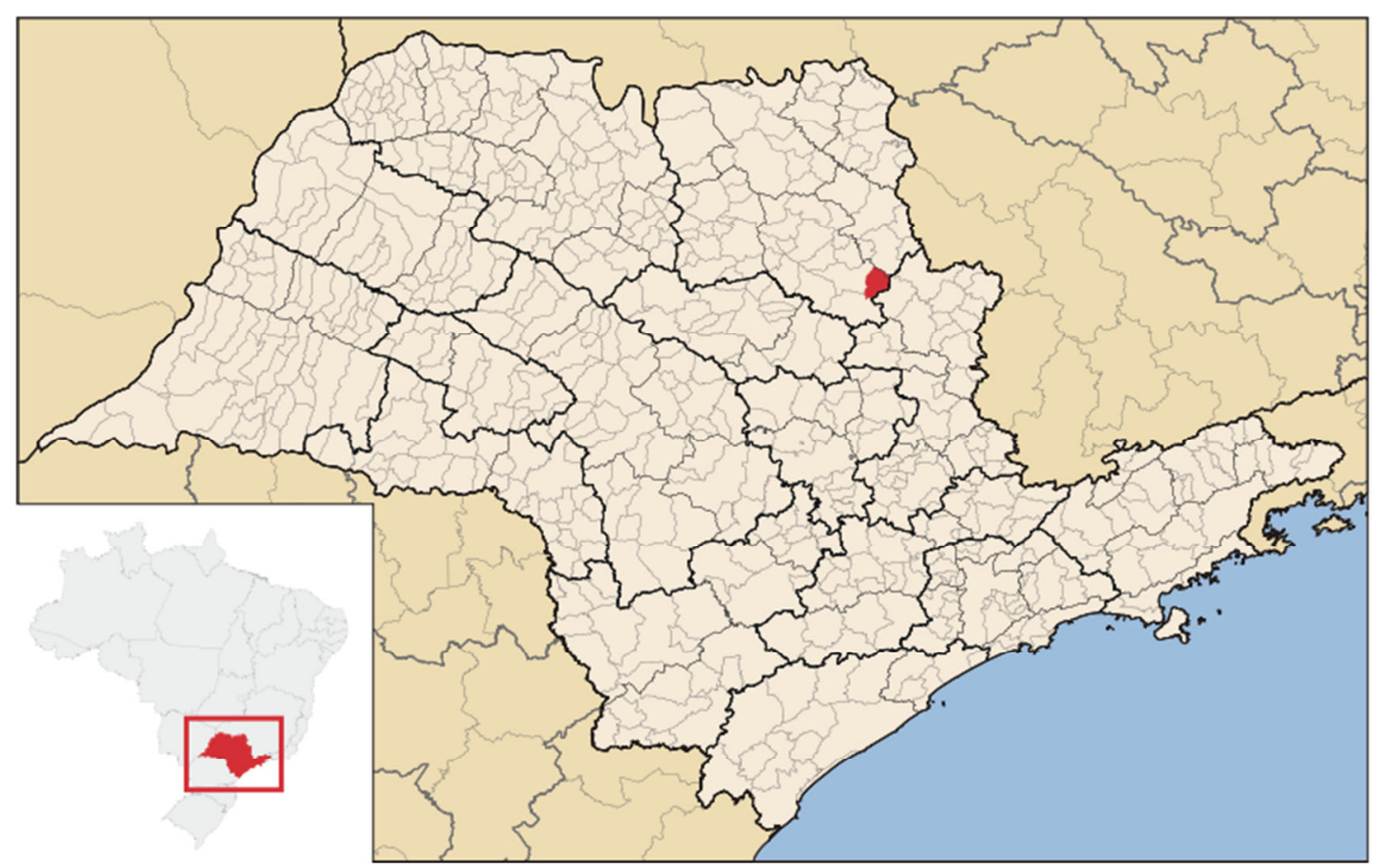

Fig. 1: Santa Rosa de Viterbo no Estado de São Paulo

Pertencente à região de Ribeirão Preto, Santa Rosa é uma pequena cidade do interior com pouco mais de vinte e três mil habitantes, segundo dados de $2010^{1}$. Até 1910, o futuro município ainda era parte do território de São Simão, hoje cidade vizinha, como ocorreu com Ribeirão Preto, que se tornou independente em 1871. O povoamento desta área iniciou-se no final do século XVII com o desenvolvimento da atividade mineradora no interior do país, quando paulistas em direção a Goiás criaram a trilha que posteriormente ficou conhecida como o Caminho do Anhanguera, estabelecendo fazendas que permitiriam a formação de cidades (BRIOSCHI, 1999a).

\footnotetext{
${ }^{1}$ Outras informações podem ser verificadas na homepage da prefeitura municipal: http://santarosa.sp.gov.br/
} 
No entanto, foi apenas no século XIX que a região começou a adquirir o formato atual. Com a ascensão da cultura cafeeira no Centro-Sul do país em detrimento da produção de cana-de-açúcar e algodão no Nordeste, uma grande massa populacional migrou para esta região que se expandia rapidamente, substituindo a criação de gado e gêneros de subsistência pela monocultura (BRIOSCHI, 1999b, p. 57-77). Favorecida pela existência da "terra roxa", ou seja, um solo avermelhado devido a rochas basálticas propícias para o desenvolvimento da agricultura (ROSSINI; OLIVEIRA, 1999), grandes fazendas transformaram o nordeste paulista em um dos lugares mais prósperos do Brasil, com Ribeirão Preto, uma das vilas mais recentes, recebendo o título de "capital do café" e a região o nome de "Alta Mogiana", em referência a Estrada de Ferro Mogiana fundada em 1872.

Nela localizada, Santa Rosa de Viterbo se beneficiou de todo esse crescimento econômico, recebendo imigrantes, principalmente italianos, para trabalhar na lavoura. $\mathrm{Na}$ década de 30 do século $\mathrm{XX}$, um fato marcaria a história do município até os dias atuais: a família Matarazzo comprou a principal fazenda da cidade $^{2}$, denominada Sociedade Agrícola Fazenda Amália ${ }^{3}$, na qual a maior parte dos habitantes do município viveria até os anos de 1960.

Ao contrário da maioria das fazendas do nordeste paulista, a Fazenda Amália se especializou no plantio de cana-de-açúcar, implementada pelo seu antigo proprietário, Henrique dos Santos Dumont ${ }^{4}$, antes mesmo da crise de 1929, se inserindo na expansão da agroindústria açucareira no Estado de São Paulo (SILVA, 2007, p. 21).

Apesar de concorrer com outras fazendas da família, nela foi construída toda a estrutura de uma pequena cidade, com hospital, escola, igreja, comércio, etc., além de um palacete onde os Matarazzo permaneciam quando a visitavam. Para se ter uma ideia, personalidades como Nelson Rockefeller, Dom Pedro de Orleans e Bragança e Juscelino Kubitschek foram recebidas no palacete da família em Santa Rosa (SILVA, 2007). Desta

\footnotetext{
${ }^{2}$ Apesar da sede da Fazenda Amália estar localizada na cidade de Santa Rosa de Viterbo e a maioria dos seus moradores serem santa-rosenses, a propriedade, na sua fase inicial, englobava terras dos atuais municípios de Cajuru, Santa Cruz da Esperança, São Simão, Serra Azul e Tambaú, além, é claro, de Santa Rosa (SILVA, 2007, p. 2). Segundo Silva (2007, p. 13), a fazenda chegou a ter uma dimensão de onze mil alqueires de terras (26.400 hectares).

${ }^{3}$ Nos referimos apenas a compra da totalidade das terras pela família Matarazzo, pois, em 1920, esta já a tinha comprado em sociedade com outros dois grandes empreendedores, o Conde Alexandre Siciliano e o Coronel Francisco Schmidt.

${ }^{4}$ Foi Henrique Santos Dumont, irmão de Santos Dumont, inventor do avião, que, em 1908, construiu um ramal ferroviário ligando a Fazenda Amália ao tronco da Companhia Mogiana de Estradas de Ferro. Em seu trajeto, este ramal, denominado pela Companhia de Ramal Santos Dumont, passava por Santa Rosa de Viterbo e se encerrava na sede da fazenda. O seu último trecho foi fechado em 1967.
} 
forma, a família, uma das mais importantes do país na época, passou a exercer grande controle sobre a vida dos moradores e a administração da cidade.

Esta influência não foi apenas econômica e política, mas também simbólica. O Conde Francisco Matarazzo Júnior, o Conde Chiquinho, filho de Francesco Matarazzo e administrador das indústrias da família após a morte de seu pai em 1937, foi o maior empresário latino-americano por mais de três décadas (COUTO, 2004a, p. 26). Filho do italiano mais rico do mundo em 1920 (COUTO, 2004a, p. 30), o sobrenome Matarazzo tornou-se sinônimo de industrialização no Brasil, que acrescido de títulos nobiliários, permitiu a sua mitificação. Como afirma Couto (2004b, p. 101), "no imaginário popular, Matarazzo podia quase tudo", não sendo diferente em Santa Rosa. O que se verifica é uma grande admiração pelos membros desta família, suavizando os conflitos trabalhistas que existiram na Fazenda Amália e contribuíram para o endividamento dos proprietários ${ }^{5}$. Inclusive, a atual (2011) presidente das Indústrias Reunidas Francesco Matarazzo, Maria Pia, filha caçula do Conde Chiquinho, ainda frequenta e se hospeda no palacete construído na fazenda, pois, entre outros motivos, um dos seus filhos é morador da cidade.

Desta maneira, devemos considerar que a Fazenda Amália é uma referência para a maioria da população santa-rosense, mesmo após o êxodo rural da década de 1960 decorrente de uma greve e posterior expulsão dos seus moradores. Isto ficará claro nos capítulos da dissertação que trata mais especificamente da constituição desse município, abrangendo o seu papel na valorização de determinados bens como símbolos culturais locais.

De qualquer modo, nossa pesquisa não está focada apenas na fazenda, mesmo com sua representatividade, mas na construção e apropriação de patrimônios culturais em todo o espaço municipal. A fazenda se destaca, pois é a origem de grande parte dos moradores da cidade, enquanto a zona urbana, apesar de existir concomitantemente à fazenda ao longo do século XX, somente atingiu o contorno atual no final da década de 1960, quando os moradores da fazenda começaram a migrar. Com mais moradores, Santa Rosa ampliou a sua infraestrutura, diversificou a economia e desenvolveu novas práticas culturais.

Nesta nova configuração, na década de 1980 ocorreram as primeiras medidas para a institucionalização do setor cultural no município. Em 1984, com a Lei no 1.166 , foi criada a Fundação Cultural de Santa Rosa de Viterbo ${ }^{6}$, com o objetivo de desenvolver uma política artístico-cultural para a cidade. Embora também receba recursos privados para a sua

\footnotetext{
${ }^{5}$ Segundo informações apresentadas por Silva (2007, p. 108), quando Maria Pia assumiu os negócios da família em 1977, ela teve que administrar uma dívida calculada em quatrocentos milhões de dólares.

${ }^{6}$ A Fundação Cultural iniciou suas atividades no ano de 1985, quando a lei do ano anterior foi sancionada pelo prefeito municipal. Santa Rosa não possui uma Secretaria da Cultura, mas a Fundação exerce esta função.
} 
manutenção, como característico de uma fundação ${ }^{7}$, pode-se considerar que ela assumiu, desde o seu início, o papel de secretaria da cultura, sendo a responsável pelas políticas públicas culturais de Santa Rosa.

Pela Fundação são realizadas atividades comuns à maioria dos municípios brasileiros, como o desfile cívico no aniversário da cidade, o carnaval de rua, a festa do Réveillon, eventos comemorativos, apresentações públicas, entre outros, além de eventos locais típicos, como o Encontro Anual de Folia de Reis, a Semana Universitária Santa-rosense (SUSA) e apresentações das bandas e fanfarras. Ainda se destacam participações do município em projetos regionais e estaduais, como o Encontro Regional de Dança, Encontro Regional de Corais e Mapa Cultural Paulista ${ }^{8}$.

A Fundação Cultural, portanto, ao longo de mais de vinte e cinco anos, foi a responsável pela organização de eventos e manutenção de projetos culturais, como os relacionados a musica, sua principal "frente de trabalho". Esta continuidade deve-se a duas personalidades da cidade, o ex-prefeito, já falecido, Nagib Moussa (administração 19831988), que, junto com seu filho e futuro prefeito Omar Nagib (administração 1993-1996), sempre apoiou a criação da Estação da Cultura $^{9}$ em 1985, primeira sede da Fundação Cultural $^{10}$, e Maurílio de Oliveira Júnior, músico ribeirão-pretano na época, que a convite do então prefeito, mudou-se para Santa Rosa para dirigir a banda sinfônica e assumiu diversos projetos existentes até hoje. Basicamente, todas as atividades culturais já realizadas ou foram criadas por essas pessoas ou passaram pela sua aprovação.

Devido à importância da Estação para a existência e atividades da fundação e pela importância histórica que a ferrovia possui para a cidade, em 1992, a Fundação Cultural solicitou ao Ministério Público Estadual o tombamento das Estações Ferroviárias de Santa Rosa de Viterbo, Nhumirim (pertencente ao município) e os leitos das ferrovias. Com uma Ação Civil Pública favorável, a área foi destinada para preservação em 2008 e, hoje, existem projetos para revitalizá-la.

\footnotetext{
${ }^{7}$ Por exemplos, alguns instrumentos musicais da Banda Sinfônica de Santa Rosa de Viterbo foram doações de empresas da cidade e região.

${ }^{8}$ O Mapa Cultural Paulista é um projeto do Governo do Estado de São Paulo, criado em 1995, para fomentar e divulgar a produção cultural estadual, principalmente a produzida no interior. Por meio de exposições e apresentações, artistas divulgam seus trabalhos, que podem estar relacionados a musica, literatura, fotografia, teatro, entre outros, primeira na sua cidade de origem, depois na região e, finalmente, na capital paulista.

${ }^{9}$ A Estação da Cultura é a estação do ramal ferroviário da Companhia Mogiana construída no século XX e restaurada para abrigar a escola de música da cidade e a sede da Fundação Cultural.

${ }^{10}$ Quando criada, a Estação da Cultura congregava a sede da Fundação Cultural e a Escola de Música Plácido Bertocco, responsável pela Banda Sinfônica de Santa Rosa de Viterbo. Em 2000, com um novo prédio para a Fundação Cultural, a Escola de Música passou a ser a única ocupante do espaço.
} 
Como parte dessa iniciativa, no ano de 2006, foi criado, por meio da Lei $\mathrm{n}^{\mathrm{o}} 3054$, o Conselho Municipal de Preservação do Patrimônio Histórico, Artístico, Paisagístico e Cultural, com o intuito de garantir a manutenção e valorização dessas construções já reconhecidas como de grande importância para a cidade e identificar outras. Contudo, segundo informações do maestro e diretor cultural Maurílio de Oliveira Júnior, depois de sua criação, os membros do Conselho não conseguiram desenvolver uma agenda para a questão patrimonial no município, com o grupo se dissipando. $\mathrm{O}$ seu intuito, portanto, no cargo que exerce, é conseguir que novas reuniões sejam realizadas para que o Conselho se fortaleça, novos membros sejam selecionados e outros projetos possam surgir. Desta forma, mesmo se entendermos que as atividades já realizadas, como desfiles e apresentações, são práticas de valorização e preservação de um patrimônio local, pois são manifestações de uma cultura, não foi essa a abordagem que as sustentaram ao longo desses anos, mas, principalmente, o interesse da população em frequentar atividades de lazer e recreação.

Sem uma política específica para o patrimônio cultural, com exceção das estações ferroviárias, não seria possível realizarmos uma pesquisa sobre as obras que são classificadas como patrimoniais pelo poder público, pois elas praticamente não existem. Utilizando, todavia, concepções, como as adotadas por Gonçalves (2007), buscamos analisar quais bens culturais são entendidos como símbolos de identidade, memória e cultura pela população local. De acordo com Gonçalves (2007), todo grupo humano seleciona, coleciona e valoriza um conjunto de objetos/ obras como uma referência comum/ compartilhada, acrescentando ao seu valor de uso funções simbólicas que garantem a sua continuidade. Neste sentido, o autor acredita que antes de um conceito formulado no século XVIII durante a formação dos Estados Nacionais, a ideia de patrimônio é uma "categoria de pensamento".

Partindo deste pressuposto, os patrimônios culturais que apresentamos neste trabalho são aqueles bens que apresentam as características simbólicas que os permitem serem vistos desta maneira pelos santa-rosenses. Não são bens que, necessariamente, são reconhecidos pelo poder público como parte da identidade local, mas são construídos e apropriados com tais pela população.

Assim como em Silva (2001, p. 79), entendemos que

o real de uma cidade não são só a sua economia, a sua planificação física ou os seus conflitos sociais mas também as imagens imaginadas construídas a partir de tais fenômenos, e também as imaginações construídas por fora deles, como exercício fabulatório, em qualidade de representação de seus espaços e de suas escrituras. 
Desta maneira, não discutiremos, ao longo da dissertação, apenas as resoluções oficiais sobre o tema, mas também as representações sociais que permitem atribuir a um bem, pela ótica dos grupos sociais, o papel de patrimônio cultural. Pretendemos identificar e analisar os valores que são atribuídos aos diferentes bens espalhados pela cidade, destacando aqueles que concentram as características que permitem sua preservação e valorização como símbolos locais. Assim sendo, discorreremos sobre os usos sociais do patrimônio, reavaliando o seu conceito nas interseções entre a literatura e o senso comum, e as representações sociais que legitimam a classificação de determinados bens como representativos da memória social.

Como a nossa pesquisa se baseia na percepção dos moradores da cidade, estabelecemos mecanismos para a participação dos mesmos em algumas etapas da produção da dissertação, como na revisão dos textos que utilizaram transcrições de entrevistas. Por conseguinte, foi possível, entre aqueles que mantiveram o contato estabelecido inicialmente, o acompanhamento de algumas das discussões elaboradas durante os mais de dois anos de escrita da dissertação, incentivando-os a refletir sobre as imagens produzidas sobre a cidade e seus bens culturais.

Para tanto, elaboramos, a partir de referências bibliográficas sobre história oral e mediação cultural, pressupostos para a participação dos entrevistados na pesquisa, desde o tipo de relação a ser incentivada entre pesquisador e colaborador às formas de intervenção deste na dissertação. Em seguida, transcorremos sobre a possibilidade dos participantes, enquanto seres sociais, serem capazes de produzir uma análise reflexiva do passado, principalmente a partir de suas experiências, ou se apenas reproduzem convenções sociais.

Acreditamos, todavia, que, inicialmente, fosse importante apresentar a formação de uma ideia de patrimônio cultural nacional, refletindo sobre os conceitos e práticas existentes no Brasil ao longo do século XX e que influenciam a nossa percepção e ação de classificar algo como um patrimônio cultural. Nesse sentido, no Capítulo 2, produzimos uma revisão de literatura para situar o surgimento e o desenvolvimento de um patrimônio cultural brasileiro, sejam em leis e decretos como nos discursos das políticas culturais.

Somente após essa revisão, que apresenta um quadro dos discursos nacionais sobre o tema, que passamos a analisar a formação de patrimônios culturais locais em Santa Rosa de Viterbo, considerando os predicados sociais que determinados bens culturais da cidade adquiriram. Com a aplicação de entrevistas, abordamos alguns dos valores que os habitantes atribuem a quatro bens locais, a Banda Sinfônica de Santa Rosa, a Semana Universitária 
Santa-rosense (SUSA), Fazenda Amália e a Folia de Reis, que, pela quantidade de citações e importância apresentada pelos participantes, utilizamos como casos exemplares.

Como toda pesquisa de campo que depende de um conjunto de interlocutores para a sua realização, algumas dificuldades surgiram para a manutenção do contato e participação dos entrevistados. Nem todos aqueles com quem conversamos foram solícitos durante todo o período de produção da dissertação, impossibilitando o cumprimento de todos os pressupostos visados por uma pesquisa colaborativa. No entanto, outros sempre se mostraram disponíveis para discussões e revisões, auxiliando-nos para as conclusões apresentadas. De qualquer modo, as questões metodológicas desenvolvidas neste trabalho não se resumem à sua aplicação aos treze entrevistados deste projeto, mas servem como referências para outras ações que busquem um diálogo com a sociedade, principalmente naquelas que utilizam entrevistas e anseiam por um maior protagonismo das pessoas envolvidas.

Como um dos resultados, utilizamos tanto as opiniões dos moradores como documentos internacionais, sobretudo resoluções da United Nations Educational, Scientific and Cultural Organization (UNESCO), para defendermos a necessidade de se analisar o patrimônio como um processo. Deste modo, procuramos rever a concepção que considera o patrimônio cultural somente como um objeto ou evento e propor que esses bens são símbolos, alegorias de um processo mais amplo. Portanto, tão importante quanto compreender o valor de um bem, é reconstruir o percurso social que permite uma obra ser vista como uma herança que deve ser preservada e reconhecida. 


\section{O PATRIMÔNIO CULTURAL BRASILEIRO: SUA INVENÇÃO E DESENVOLVIMENTO EM DISCURSOS E AÇÕES}

\subsection{O patrimônio cultural brasileiro}

Discutir a constituição de um patrimônio cultural brasileiro, seja em seu nível discursivo como prático, requer conhecer o contexto no qual surgiram alguns questionamentos sobre a identidade nacional, as características que supostamente nos definem e diferenciam como nação. No Brasil, esta preocupação torna-se evidente com o Movimento Modernista, da arte de Tarsila do Amaral, Portinari à literatura de Oswald de Andrade, Manuel Bandeira e principalmente, na conjuntura deste capítulo, Mário de Andrade (BOSI, 2007, p. 331-379), apesar de anteriormente outros intelectuais também terem buscado símbolos de "brasilidade" em suas obras, como Euclides da Cunha, Lima Barreto, analisados por Sevcenko (2003), e Monteiro Lobato (2008).

Para uma análise que melhor explicite o movimento, Lafetá (2000, p. 20) o divide, de forma operatória, em um período que prevaleceu o projeto estético (década de 1920) e outro o ideológico (década de 1930). O projeto estético se caracterizava pela crítica à velha linguagem, oficial, acadêmica, ao mesmo tempo em que incentivava a experimentação, o uso de novas linguagens, incorporando usos populares e regionais. Já a partir da década de 1930, com o aumento da industrialização, imigração e urbanização, a crítica ao Brasil arcaico tornou-se mais acentuada, e o perfil ideológico do movimento mais claro ao discutir "a função da literatura, o papel do escritor, as ligações da ideologia com a arte” (LAFETÁ, 2000, p. 28).

Até os anos de 1920, a noção de um país novo, tropical e mestiçado era tratada em forma de constrangimento pelos nossos escritores, que para se aproximar da cultura europeia privilegiava uma abordagem idealista ou civilizatória. O Modernismo supera esta perspectiva e o que era visto como nossas deficiências, símbolos do atraso, transformam-se em nossas superioridades (CÂNDIDO, 2008, p. 127).

Não se precisaria mais dizer e escrever, como no tempo de Bilac ou do conde Afonso Celso, que tudo aqui é belo e risonho: acentuam-se a rudeza, os perigos, os obstáculos da natureza tropical. O mulato e o negro são definitivamente 
incorporados como temas de estudo, inspiração, exemplo. O primitivismo é agora fonte de beleza e não mais empecilho à elaboração da cultura. Isso na literatura, na pintura, na música, nas ciências do homem (CÂNDIDO, 2008, p. 127).

No contato com as vanguardas europeias, estes intelectuais, interessados pelo futurismo, dadaísmo e surrealismo entenderam que um rompimento com o passado só teria sentido em um país que apresentasse uma continuidade, tradição. Deste modo, a modernização artística foi acompanhada de discursos políticos e nacionalistas que pretendiam revisar e reinventar as representações brasileiras. Uma posição, portanto, que ao mesmo tempo em que negava a história construída, buscava reescrevê-la em uma perspectiva antropofágica (FONSECA, 2005, p. 90).

Mesmo considerando as nações europeias ocidentais "mais maduras" e "mais civilizadas" (GONÇALVES, 2002, p. 46), "um certo número de escritores se aplica a mostrar como somos diferentes da Europa e como, por isso, devemos ver e exprimir diversamente as coisas" (CÂNDIDO, 2008, p. 129). Esta diferença, principalmente no que se refere ao patrimônio cultural, começou a ser elaborada nas viagens destes intelectuais a Minas Gerais.

São eles que denunciaram o abandono das cidades históricas do Estado e começaram a pensar em iniciativas para a preservação dos monumentos. Na década de 1920, depois das visitas de Rodrigo Melo Franco de Andrade, Lúcio Costa, Mário de Andrade, Minas Gerais passou a ser considerada "o berço de uma civilização brasileira” (FONSECA, 2005, p. 92).

O interesse por Minas Gerais deve-se ao fato de ser a região onde se concentrava uma grande quantidade de obras arquitetônicas do barroco brasileiro, considerado símbolo da "redescoberta" do Brasil pelos modernistas. Segundo Gonçalves (2002, p. 68-69), de 1937 a 1979, a maioria das obras consideradas patrimônio cultural era representante do barroco e, em 1982, 70 \% do patrimônio cultural brasileiro estava localizado em Minas Gerais. "Nesse sentido, a assim chamada "preservação" deve ser pensada como trabalho transformador e seletivo de reconstrução e destruição do passado, que é realizado no presente e nos termos do presente" (ARANTES, 1984, p.9).

O interesse pelo barroco mineiro como símbolo de brasilidade pode ser entendido como uma invenção de tradição, que no discurso de continuidade tenta estabelecer um vínculo com um determinado passado histórico. "Por 'tradição inventada' entende-se um conjunto de práticas, normalmente reguladas por regras tácita ou abertamente aceitas; tais práticas, de natureza ritual ou simbólica, visam inculcar certos valores e normas de comportamento através da repetição (...)” (HOBSBAWN; RANGER, 2008, p. 9). 
Como uma das principais figuras do Modernismo, Mário de Andrade se destaca. Em 1924, viaja a Minas Gerais na "Viagem de descoberta do Brasil". Em 1927, 1928 e 1929, percorre o norte e nordeste do país em suas "Viagens etnográficas". E ao ir ao encontro do "Brasil autêntico, dos lugares de memória nacional", começa a inventariar o patrimônio cultural brasileiro (NOGUEIRA, 2005, p. 65).

Para Mário, o Brasil se tornaria civilizado quanto mais se afastasse da imitação do modelo europeu, principalmente francês, e criasse sua própria identidade, estabelecesse seus ideais. Desta maneira, seu olhar se volta para o interior do país, menos ou nada contaminado pelo espírito da Belle Époque, tão presente em cidades como a capital Rio de Janeiro, analisada por Needell (1993).

Nos registros de sua viagem por Minas Gerais, o poeta expressa a preocupação de preservar aquela arquitetura do século XVIII, em grande parte religiosa católica. Ainda, ao não reconhecer na população das pequenas cidades visitadas condições para identificar e dialogar com este patrimônio descoberto, reafirma o papel dos intelectuais modernistas pela guarda da memória nacional (NOGUEIRA, 2005, p. 89).

Esta posição em relação às populações interioranas não é resultado de um desinteresse por elas, muito pelo contrário. Durante suas viagens etnográficas, uma das maiores preocupações de Mário é "colher e registrar, diretamente da fala do povo, os elementos constitutivos da brasilidade procurada" (NOGUEIRA, 2005, p. 113). Isto revela uma das características que perpassa toda a obra do autor e sua história política: a preocupação com a cultura popular, mesmo que sua concepção de popular esteja, muitas vezes, mais próxima da noção de folclore do que a abrangência com que a compreendemos hoje.

Para colher e registrar as expressões culturais, a fotografia torna-se um dos seus principais instrumentos de trabalho, inclusive na chefia do Departamento de Cultura de São Paulo e na assistência técnica do Serviço do Patrimônio Histórico e Artístico Nacional (SPHAN). Sua metodologia consistia em preservar pela captura da imagem o que era transitório ou que pela ação do tempo poderia desaparecer. Além disto, acrescentava a cada fotografia anotações como data, local e nome das pessoas presentes, o que demonstra o detalhamento técnico que permite até os dias atuais a utilização do seu acervo como importante fonte de pesquisa (NOGUEIRA, 2005, p.134-136).

À luz do observador, a construção de um projeto nacional modernista pelo inventário do patrimônio cultural, instituiu um novo marco cronológico da História da Cultura Brasileira. Nesse processo, falas, sons, melodias, ritmos, cores, aromas, sabores, saberes, superstições e festas são sentidos físicos e simbólicos do Brasil. 
Dar uma alma ao Brasil é viajar pelo interior em busca de seu sentido (NOGUEIRA, 2005, p. 175).

\subsection{Dos discursos às instituições}

Se a década de 1920 se caracterizou por uma Revolução Intelectual, o decênio seguinte foi marcado por reformas políticas que influenciaram diretamente a temática do patrimônio nacional. Em 1932, aconteceu em São Paulo o movimento revolucionário que dissolveu o Congresso Nacional e pôs fim à vigência da Constituição de 1891. Desta data até 1937, somente medidas isoladas trataram do patrimônio cultural. Como exemplo, em 1933 foi tombado o conjunto urbanístico de Ouro Preto, em 1934 foi aprovado um novo regulamento para o Museu Histórico Nacional e, no mesmo ano, promulgada a Constituição Federal de 1934, que em seus artigos se referia à necessidade de proteção, pelo Estado, dos objetos de interesse histórico e do patrimônio artístico do país (GONÇALVES, 2007, p. 28).

Em 1937, um golpe de Estado estabeleceu o Estado Novo, um regime autoritário que novamente fechou o Congresso Nacional assim como os partidos políticos. Em meio à censura e perseguições, o então ministro da Educação e da Saúde, Gustavo Capanema, assume a missão de criar instituições culturais e educacionais (GONÇALVES, 2002, p. 4041). Nesta conjuntura de mudanças iniciadas em 1932, são criadas instituições como a Universidade de São Paulo (1934), o Departamento de Cultura de São Paulo (1935), o Instituto do Livro (1937), o Museu Nacional de Belas Artes (1937), entre outros.

Na crise política, intelectuais como Mário de Andrade, Paulo Duarte e Sérgio Millet se filiam ao Partido Democrático. Entre outras propostas, "elegem as questões culturais como solução para os problemas enfrentados pela elite na condução do Brasil moderno" (NOGUEIRA, 2005, p. 200). O envolvimento destes intelectuais com a imprensa e a administração pública e federal permite então que o problema da preservação do patrimônio nacional se transformasse em leis e projetos.

No governo Vargas, com a reorganização do Estado, os intelectuais começam a participar da "construção da nação". Em 1936, o então ministro Gustavo Capanema recorre a Mário de Andrade para a elaboração de um anteprojeto para a proteção das obras nacionais. A concepção do autor era ampla. A partir da categoria de "arte", cria oito subcategorias para abranger todos os bens patrimoniais: arqueológica, ameríndia, popular, histórica, erudita nacional, erudita estrangeira, aplicada nacional, aplicada estrangeira (CHAGAS, 2003, p. 
100). Como se vê, a noção de patrimônio de Mário buscava abranger toda a heterogeneidade brasileira, todas as classes e raças.

No mesmo ano, o anteprojeto foi entregue e aprovado por Gustavo Capanema, mas que para transformá-lo em projeto, junto com Rodrigo Melo Franco de Andrade, indicado por Mário, e equipe, desenvolveu uma nova versão a ser enviada ao Parlamento (CHAGAS, 2003, p. 99). O projeto de lei suprimia concepções do anteprojeto, tornava menos abrangente a noção de patrimônio e estabelecia sua forma de proteção, o tombamento. Em 1936, o Serviço do Patrimônio Histórico e Artístico Nacional (SPHAN) começa a funcionar experimentalmente e em 30 de novembro de 1937, pelo Decreto-Lei 25 promulgado pelo presidente Getúlio Vargas, passa a integrar o Ministério da Educação e Saúde (FONSECA, 2005, p. 97).

Na definição do Decreto-Lei, o patrimônio histórico e artístico nacional é o

(...) conjunto dos bens móveis e imóveis existentes no país e cuja conservação seja de interesse público, quer por sua vinculação a fatos memoráveis da história do Brasil, quer por seu excepcional valor arqueológico ou etnográfico, bibliográfico ou artístico (BRASIL, 1937).

No que se refere à preservação dos bens móveis e imóveis, o decreto estabeleceu quatro Livros do Tombo (Arqueológico, Etnográfico e Paisagístico; Histórico; Belas Artes; Artes Aplicadas), nos quais as obras consideradas patrimônio nacional deveriam ser registradas e resguardadas para que não fossem, sem a prévia autorização do SPHAN, destruídas, demolidas, mutiladas, reparadas, pintadas ou restauradas (BRASIL, 1937).

O decreto tinha como característica uma solução para o direito de propriedade, que até o momento era um dos fatores que limitavam a preservação do patrimônio, com recusas de diversos projetos pelo Congresso Nacional. Ao contrário da desapropriação, o tombamento manteria a posse do bem pelo proprietário, apenas limitando o seu uso (GONÇALVES, 2007, p. 35).

Deste modo, os recursos operacionais são o que caracterizam o decreto e o aspecto conceitual e organizacional é a maior contribuição do anteprojeto. Para "viabilizar a proteção legal era necessário referir-se a coisas ('bens móveis e imóveis')”, o que levou o SPHAN a trabalhar principalmente com o patrimônio arquitetônico, enquanto outras manifestações 
culturais, como as folclóricas, por exemplo, não cabiam na noção de patrimônio (FONSECA, 2005, p. 105).

Devemos considerar que, na época de criação do SPHAN, apenas as obras de origem e influência europeia eram vistas como dignas de preservação, inclusive pela sociedade, pois, apesar das discussões produzidas pelos modernistas, manifestações indígenas e africanas eram ainda marginalizadas e sequer consideradas como um símbolo de brasilidade. Assim sendo, as políticas adotadas nos primeiros anos do SPHAN não devem ser entendidas apenas como uma negação de outras formas de expressão da cultura nacional, mas como um reflexo do que era definido como cultura nas primeiras décadas do século XX no Brasil.

Segundo Chagas (2003, p. 102-103), a concepção de tombamento adotada pelo SPHAN não era a defendida por Mário de Andrade. Para o poeta, a reprodução da obra folclórica (provérbios, receitas culinárias, músicas, etc.), sua descrição geral e o registro por filmagem e fotografia também seria uma forma de tombamento, que, ao verificarmos a política da instituição, não foi utilizada.

Esta abordagem pode ser comparada com o que Buckland (1991) diz a respeito das obras, objetos e práticas que não podem ser preservados em si em museus, bibliotecas, arquivos ou outras instituições culturais. Para ele, seja o intangível, como crenças, danças e festas, quanto obras imóveis, podem ser representadas por documentos/ objetos que os descrevem. Portanto, toda informação pode ser "uma coisa" passível de ser registrada, organizada e acessada pela população. O importante é que esta "coisa" seja informativa daquilo a que se refere, pois através desta representação o observador se aproxima do que quer conhecer. O registro torna-se uma representação de um objeto ou prática, que ao ser classificado como patrimônio também é uma representação de valores selecionados.

No entanto, o trabalho da instituição privilegiou a arquitetura religiosa dos séculos XVI, XVII e XVIII, primordialmente barroca e mineira. Foi através desta prática que se formularam os critérios para as futuras decisões sobre tombamentos e trabalhos de restauração (FONSECA, 2005, p. 110), o que causava transtornos aos técnicos quando as obras a serem restauradas não se enquadravam nos limites usuais, como apresentado por Gonçalves (2007) ao discutir a restauração arquitetônica no Estado de São Paulo dirigida pelo SPHAN.

Não é a toa que a concepção de patrimônio cultural nas primeiras décadas do SPHAN é denominada como a de "pedra e cal": 


\begin{abstract}
A imagem que a expressão "patrimônio histórico e artístico" evoca entre as pessoas é a de um conjunto de monumentos antigos que devemos preservar, ou porque constituem obras de arte excepcionais, ou por terem sido palco de eventos marcantes, referidos em documentos e em narrativas dos historiadores. Entretanto, é forçoso reconhecer que essa imagem, construída pela política de patrimônio conduzida pelo Estado por mais de sessenta anos, está longe de refletir a diversidade, assim como as tensões e os conflitos que caracterizam a produção cultural do Brasil, sobretudo a atual, mas também a do passado (FONSECA, 2003, p. 56).
\end{abstract}

De 1936 a 1967, o SPHAN foi dirigido por Rodrigo Melo Franco de Andrade, período hoje denominado de "fase heroica" devido ao caráter inovador da instituição, o desconhecimento da maior parte da população sobre as questões patrimoniais e a luta de seu diretor, com grande prestígio entre intelectuais e funcionários, para uma maior divulgação e sucesso do trabalho realizado.

Nos seus discursos, ele narra o que chama de "uma obra de civilização" para o Brasil. Como um país novo, o país necessitaria evoluir de um estágio "mais primitivo" para o "mais avançado", condizente com sua ideia de civilização, ou seja, a civilização europeia ocidental. Este retrato, ao contrário do que possa parecer, não era visto como negativo por Rodrigo M. F. de Andrade. Para ele, este era apenas um processo pelo qual um país novo deveria passar, que seria superado quando os brasileiros assumissem e defendessem nossa cultura ou tradição. Desta forma, propõe registrar tudo o que envolve o patrimônio histórico e artístico nacional (GONÇALVES, 2002, p. 43-46).

$\mathrm{Na}$ fase "heroica", a decisão sobre o que deveria ser tombado era quase exclusivamente dos funcionários da instituição e seus colaboradores. Como já dissemos, a maior parte da população desconhecia o Serviço e os intelectuais assumiram uma postura de autoridade perante o patrimônio que intimidava interferências externas. Como previsto, o foco das ações foi dirigido para a arquitetura religiosa de Minas Gerais, barroca e católica. Segundo Fonseca (2005, p. 113), “foram tombados, até o ano de 1969, 803 bens, sendo 368 de arquitetura religiosa, 289 de arquitetura civil, 43 de arquitetura militar, 46 conjuntos, 36 bens imóveis, seis bens arqueológicos e quinze bens naturais".

Para Rodrigo M. F. de Andrade, apropriar-se do patrimônio era apropriar-se do passado, passado este que representaria toda a nação e não somente algumas regiões do país, o que na realidade não aconteceu. Outra preocupação é o que ele considerava o processo de desaparecimento do patrimônio histórico e artístico nacional, resultado, para ele, da indiferença tanto das massas como das classes mais favorecidas para a necessidade de preservação. Deste modo, a ênfase no seu discurso recai sobre a tarefa de "educar" a 
população sobre a identidade nacional representada pelo patrimônio (GONÇALVES, 2002, p. 93), apesar de muitos funcionários se afastarem dos canais de difusão do Estado por acreditarem que esta não era uma função da Instituição, reduzindo a visibilidade dos trabalhos apenas aos meios mais intelectualizados (FONSECA, 2005, p. 125).

Observa-se neste período que os requisitos para o tombamento restringiram-se a informações técnicas, na maioria arquitetônicas, deixando pouco espaço para uma análise da função social destas obras. Junto a isto, a pouca divulgação do SPHAN e a posição dos técnicos amplamente especializados não permitiram que se pensasse a importância do patrimônio para a sociedade, que de alguma forma também atribui valores aos elementos da cidade.

Em 1967, Rodrigo M. F. de Andrade se aposenta e é sucedido pelo arquiteto Renato Soeiro, simbolizando o fim da fase "heroica". Ao contrário do antigo diretor, Renato Soeiro não goza do mesmo prestígio e tem maiores dificuldades para resolver entraves burocráticos. Esta situação demonstra o quanto até o momento o órgão era dependente de uma figura carismática, com bom relacionamento entre autoridades e intelectuais. No entanto, no plano executivo, Renato Soeiro manteve a política de Rodrigo e sua direção é marcada pela continuidade do trabalho anterior (FONSECA, 2005, p. 141).

Se a instauração de um governo democrático em 1945 não afetou a política de preservação no Brasil, que manteve sua orientação até quase o final da década de 1960, o decênio seguinte previa maiores mudanças. Desde os anos de 1950, a política de desenvolvimento deu novo impulso para a industrialização, urbanização e interiorização do país, como na construção de Brasília. A valorização do solo urbano e o crescimento das cidades começaram a criar tensões com a preservação da malha urbana e neste ambiente de questionamentos, novas propostas receberam estímulo (FONSECA, 2005, p. 141).

Em 1965, o SPHAN recorreu a UNESCO para rever sua atuação. Nos anos seguintes, se intensificaram os discursos que citavam o valor econômico dos bens, buscando conciliar o desenvolvimento do país com as políticas de preservação. Neste ambiente, no ano de 1975, foi criado por Aloísio Magalhães e equipe o Centro Nacional de Referência Cultural (CNRC), com a proposta de estudar uma nova política para o patrimônio cultural condizente com a realidade brasileira. Como resultado, projetos culturais foram elaborados em quatro áreas ainda pouco exploradas no âmbito federal: artesanato; levantamentos socioculturais; história da tecnologia e da ciência no Brasil; levantamento de documentação sobre o Brasil (GONÇALVES, 2002, p. 74). Apesar de seu sucesso ter sido maior no campo discursivo do 
que em ações concretas, as propostas do CNRC foram incorporadas à nova política do SPHAN em 1979, no mesmo ano em que Aloísio Magalhães assume sua direção.

Para Fonseca (2005, p. 144), o CNRC, com o objetivo de atualizar a reflexão sobre a realidade brasileira, se aproximou das preocupações da Semana de 22. Formado por professores da Universidade de Brasília, o grupo ia além das finalidades do SPHAN, de eleger os símbolos da nação, buscando "indicadores para a elaboração de um modelo de desenvolvimento apropriado às necessidades nacionais". Com esse caráter inovador, os conceitos formulados pelo órgão contribuíram, na década de 1980, para a política da Secretaria de Cultura do MEC e as questões patrimoniais na Constituição Federal de 1988.

Nesta atmosfera de mudanças, Aloísio Magalhães se opõe aos discursos de Rodrigo M. F. de Andrade. Inicialmente, prefere utilizar a expressão "bens culturais", mais abrangente, do que "patrimônio histórico e artístico". Dá maior ênfase aos valores do presente do que aos do passado e assinala a importância de um maior contato com as populações locais. Além disso, elege a diversidade cultural do Brasil como cerne de seus discursos, em uma tentativa de ampliar a noção de patrimônio até o momento utilizada. Deste modo, podese considerar que Aloísio Magalhães, quatro décadas depois, se aproxima mais das ideias do anteprojeto de Mário de Andrade do que de Rodrigo em sua política. "Em oposição ao enredo da narrativa de Rodrigo, articulado pelas ideias de "civilização" e "tradição", a estória narrada por Aloísio é articulada pelas noções de "desenvolvimento" e "diversidade cultural" (GONÇALVES, 2002, p. 51).

Ao contrário de Rodrigo M. F. de Andrade, ele não vê a cultura africana e ameríndia em um estágio de evolução inferior à europeia. Baseado na ideia de diversidade, classifica todas como atuais, em processo contínuo de transformação. Ao conceber a cultura brasileira no plural, utiliza as categorias de "povo", "segmentos sociais", "comunidades", destacando a heterogeneidade da população. Outra contribuição sua foi superar a barreira dos bens móveis e imóveis e pensar as práticas sociais também como patrimônios. Para estas, bastaria a liberdade de expressão e os recursos necessários para continuar a existirem. Desta forma, podemos observar nos discursos de Aloísio Magalhães uma preocupação, ainda não sistematizada em forma de leis e projetos, com o que hoje é denominado patrimônio intangível. Neste contexto discursivo, a indiferença da população com o patrimônio não se deve ao fato dela não conhecer os valores das obras consideradas excepcionais, como Rodrigo pensava, mas a falta de representatividade desta nas obras tombadas, vinculadas apenas às elites e não a toda nação (GONÇALVES, 2002, p, 53-93). Como observa Durham (1984, p. 
32) ao analisar as relações entre cultura, patrimônio e preservação, "as classes dominantes dirigem a produção material e cultural coletiva, da qual se apropriam privilegiamente".

Entretanto, destacamos que estas concepções de Aloísio Magalhães referem-se ao campo discursivo, pois muitas de suas opiniões não se concretizaram na prática, ou seja, em leis, projetos e ações. Acreditamos ser este um dos pontos centrais quando se discute o patrimônio cultural no Brasil, pois há uma enorme distância entre o que foi dito e o que foi feito. As ações ainda estão muito aquém do que foi defendido por ele e Mário de Andrade em seu anteprojeto.

Contudo, no contexto dos anos 80 e com a atmosfera de renovação trazida por Aloísio Magalhães, as ideias apresentadas simbolizaram uma nova fase para os discursos patrimoniais no Brasil. Esta mudança de perspectiva, iniciada com o CNRC, culmina em uma nova definição de patrimônio cultural pela Constituição Federal de 1988. Para a Constituição, Artigo 216, constituem patrimônio cultural brasileiro

os bens de natureza material e imaterial, tomados individualmente ou em conjunto, portadores de referência à identidade, à ação, à memória dos diferentes grupos formadores da sociedade brasileira, nos quais se incluem:

I. as formas de expressão;

II. os modos de criar, fazer e viver;

III. as criações científicas, artísticas e tecnológicas;

IV. as obras, objetos, documentos, edificações e demais espaços destinados às manifestações artístico-culturais;

V. os conjuntos urbanos e sítios de valor histórico, paisagístico, artístico, arqueológico, paleontológico, ecológico e científico (BRASIL, 1988).

Verifica-se nesta definição que, ao contrário de exigir um caráter excepcional ao bem a ser tombado, como no Decreto-Lei de 1937, a Constituição privilegia o valor que este representa para os grupos sociais. Portanto, mais importante que as características físicas do bem é o seu significado para a sociedade, que constantemente lhe atribui sentidos. É estudar as relações sociais que permitem a seleção de um bem como representativo para a identidade, memória e ação das diferentes camadas sociais. Nesta concepção, discutir o patrimônio requer conhecer a cultura daqueles que atribuíram este valor, pois como aponta García Canclini (2007, p. 41), "a cultura abarca o conjunto de processos sociais de produção, circulação e consumo da significação na vida social".

Outro ponto de mudança é que enquanto em 1937 o patrimônio está dividido em bens móveis e imóveis, agora abrange os bens de natureza material e imaterial. Deste modo, ir 
além do patrimônio de "pedra e cal" abre um caminho para discutir a valorização e preservação de práticas culturais, como festas, culinária, lendas e outros fazeres e saberes, e examinar se o tombamento, como até então era feito, seria a melhor forma de preservá-las. No entanto, como já apontamos ao longo do texto que devemos dividir os discursos das ações quando se refere ao patrimônio cultural, não foi isto o que aconteceu.

Segundo Fonseca (2003, p. 60), o legislador atribui o tombamento apenas aos incisos IV e $\mathrm{V}$ do texto constitucional, pois são os únicos que permitem a proteção da integridade física das obras. Desta forma, "o que deveria ser uma das modalidades de formação desse patrimônio terminou por ser, durante mais de sessenta anos, a única disponível”. Apesar da citação de outros bens passiveis de classificação como patrimônio cultural brasileiro, as ações desenvolvidas ao longo dos anos pelo SPHAN apreendiam somente os bens móveis e imóveis, o que pouco mudou depois da Constituição de 1988.

Podemos considerar que a partir da década de 70 e, principalmente, 80, a política do patrimônio cultural começou a ser criticada e passar por um período de transição. Transformações também são percebidas em relação às solicitações de tombamentos. Se antes eram feitas essencialmente pelos funcionários da instituição, deste momento em diante ocorre um aumento substancial de solicitações da sociedade civil, demonstrando uma abertura do SPHAN, apesar das decisões continuarem no âmbito dos técnicos (FONSECA, 2005, p. 183217).

Os tipos de bens tombados se ampliam. Além da arquitetura religiosa e militar, aumenta o número de conjuntos, áreas industriais, construções em estilos arquitetônicos como o eclético, antes renegado pelos intelectuais, e obras referentes a grupos até então marginalizados como imigrantes e grupos religiosos africanos. Um exemplo é o terreiro de candomblé Casa Branca, em Salvador. O Conselho do SPHAN estava dividido sobre o tombamento do terreiro pelo local não apresentar um valor excepcional ou artístico, segundo a perspectiva até então adotada, que justificasse tal resolução. O que alguns conselheiros não admitiam era o valor social deste bem, como representante da cultura afro-brasileira há mais de cento e cinquenta anos. O sucesso do tombamento na época, 1984, representou uma mudança em relação ao patrimônio até então privilegiado, o luso-brasileiro (VELHO, 2006, p. 237-239).

Entretanto, o fim prático desta política, o modo de se proteger e preservar, não sofreu reformulações. "Os instrumentos de proteção continuam praticamente os mesmos: o tombamento para bens imóveis e os museus para a guarda dos bens móveis" (FONSECA, 
2005, p. 217), o que demonstra a necessidade de novas pesquisas para propor e examinar outras formas de proteção.

Novas discussões podem surgir com uma maior participação dos municípios nas questões patrimoniais. Apesar da formação de Superintendências Regionais do SPHAN ser uma realidade desde sua criação, com o intuito de inventariar as obras de todos os cantos do país (GONÇALVES, 2007, p. 43-44), pouco ainda foi feito no âmbito local. Mesmo com exemplos como o Departamento de Cultura de São Paulo dirigido por Mário de Andrade, como já citado, a preocupação das médias e pequenas cidades com o seu patrimônio cultural ainda é incipiente, senão inexistente. Para Monnet (1996, p. 220), há não mais de trinta anos que a proteção do patrimônio cultural tornou-se um instrumento de gestão urbana, com aparatos legais e sociais.

Losnak (2004, p.190) explica, por exemplo, que somente a partir da Lei $\mathrm{n}^{\circ} 9.205$, de 28 de dezembro de 1965, se instituiu a obrigatoriedade de um Plano Diretor para as cidades do Estado de São Paulo que solicitassem o direito de auxílio financeiro ou empréstimo, e que são nestes planos que encontramos algumas das primeiras iniciativas municipais em relação ao patrimônio urbano. Em Ribeirão Preto, uma cidade do Estado com uma população atual em torno de meio milhão de habitantes, o Conselho de Defesa do Patrimônio Histórico e Cultural do município foi criado apenas em 1971 (RIBEIRÃO PRETO, c2004). Já em Santa Rosa de Viterbo, que pertence à mesma região, o Conselho Municipal de Preservação do Patrimônio Histórico, Artístico, Paisagístico e Cultural foi criado no ano de 2006 (SANTA ROSA DE VITERBO, 2006). E não é de se espantar que muitas cidades do país não apresentem sequer uma política em relação ao seu patrimônio cultural local. O que se vê é que o tombamento federal continua sendo o de maior prestigio e o que efetivamente garante a proteção de um bem.

Acreditamos que pensar em discursos e ações além do atual Instituto do Patrimônio Histórico e Artístico Nacional (IPHAN) permitirá uma maior reflexão sobre o valor de excepcionalidade, valor nacional, estadual e local, incentivará medidas de proteção que superem o vigente conceito de tombamento e incluirá na categoria dos bens culturais expressões regionais de extrema importância para pequenos grupos sociais que nelas se identificam, mas que não são consideradas quando apenas valorizamos a escala nacional.

Outro aspecto positivo é que, com a maior participação dos municípios na valorização e preservação do patrimônio cultural, a população estará mais próxima do cerne das decisões, o que pode aumentar o interesse e participação social nestas discussões. Como diz Marilena Chauí (1992, p. 45), 
O Estado não pode colocar-se como centro de onde se define e se irradia a memória, pois ao fazê-lo destrói a dinâmica e a diferenciação interna da memória social e política; não pode ser produtor da memória nem o definidor do que pode e deve ser preservado. O Estado deve comportar-se como serviço público aos cidadãos (...).

Entretanto, apesar de muito ainda estar por ser feito, no que se refere ao patrimônio imaterial ou intangível, citado na Constituição Federal de 1988, observa-se a partir do final dos anos 90 no Brasil iniciativas para que sua preservação fosse realmente discutida e aplicada. Em novembro de 1997, aconteceu em Fortaleza o Seminário "Patrimônio Imaterial: Estratégias e Formas de Proteção”, que ao final produziu a Carta de Fortaleza com recomendações sobre o tema.

Entre as propostas do documento estão: "que o IPHAN promova o aprofundamento da reflexão sobre o conceito de bem cultural de natureza imaterial”; "que seja constituído um banco de dados acerca das manifestações culturais passíveis de proteção, tomando a difusão e o intercâmbio das informações ágil e acessível”; "desenvolvido um Programa Nacional de Educação Patrimonial”; “estabelecida uma Política Nacional de Preservação do Patrimônio Cultural com objetivos e metas claramente definidos", entre outras (IPHAN, 1997).

Esta preocupação com o patrimônio intangível culminou no Decreto $n^{\circ} 3.551$, de 4 de agosto de 2000, que criou o programa nacional do patrimônio imaterial e instituiu o registro dos bens culturais de natureza imaterial. Apesar de não abranger todas as recomendações da Carta de Fortaleza, o Decreto pode ser considerado um marco desta política, pois cria instrumentos legais para a preservação do patrimônio intangível.

Para isto, institui quatro livros de registros: dos Saberes; das Celebrações; das Formas de Expressão; dos Lugares, este último referente a espaços onde se concentram e reproduzem práticas culturais coletivas, e não a construções arquitetônicas em si. Para ser registrado, o bem deve apresentar praticamente as mesmas características definidas pela Constituição de 1988, "relevância nacional para a memória, a identidade e a formação da sociedade brasileira". Ainda, o título recebido passa por uma revalidação a cada dez anos, e caso não seja mais considerado Patrimônio Cultural do Brasil deverá ser mantido apenas o registro como referência do seu tempo (BRASIL, 2000).

A partir deste Decreto, novos bens começam a ser considerados patrimônios culturais brasileiros, o que incentiva novas discussões. Em 2002, a pintura corporal e arte gráfica Kusiwa dos índios wajãpi do Amapá torna-se o primeiro bem a ser registrado no Livro dos 
Saberes. Abreu (2003b), ao analisar os "patrimônios emergentes", aponta o patrimônio genético, que compreenderia desde a conservação da biodiversidade, os processos de clonagem e projetos do genoma, como um tema a ser examinado. Músicas, festas, pratos regionais, linguagens, ofícios, entre outros passam a ser analisados pelo IPHAN para futuros registros e o campo do patrimônio cultural se amplia. Portanto, esta abrangência vem a demonstrar que a noção de patrimônio intangível não se restringe somente ao folclore e a cultura popular, apesar de estarem entre os mais beneficiados com esta nova postura patrimonial.

Segundo Sant'anna (2003, p. 48-49), a experiência de países subdesenvolvidos, em desenvolvimento e asiáticos em relação aos seus patrimônios aponta para práticas de preservação que, ao invés de se preocuparem somente com a materialidade, valorizam os conhecimentos e processos que permitem a existência de seus bens culturais.

Nos países mais pobres, esta concepção deve-se ao valor atribuído às criações populares, que revelam sua importância mais pelos seus fazeres e saberes do que por construções materiais. Já no mundo oriental, esta preocupação emerge das maneiras com estas culturas interagem com suas tradições. Para Sant'anna (2003, p. 49), "a permanência no tempo das expressões materiais dessas tradições não é o aspecto mais importante, e sim o conhecimento necessário para reproduzi-las". Assim sendo, mais relevante que preservar um objeto é elaborar condições para transmitir o saber que o produz para as gerações presentes e futuras.

Argan (2005, p. 13), ao refletir sobre obras de arte, contribui para esta discussão. Para ele:

\footnotetext{
Uma vez que as obras de arte são coisas às quais está relacionado um valor, há duas maneiras de tratá-las. Pode-se ter preocupação pelas coisas: procurá-las, identificálas, classificá-las, conservá-las, restaurá-las, exibi-las, comprá-las, vendê-las; ou, então, pode-se ter em mente o valor: pesquisar em que ele consiste, como se gera e se transmite, se reconhece e se usufrui.
}

Tais iniciativas em relação ao patrimônio imaterial podem ser verificadas já na metade do século XX. Em 1950, o governo japonês concedeu a indivíduos detentores de conhecimentos e técnicas considerados importantes para o país o título de "Tesouros humanos vivos". Posteriormente, o governo também passou a considerar patrimônio cultural do Japão grupos com um saber-fazer, o que foi seguido por países como a República da Coréia, em 1964, Filipinas, em 1973 e Tailândia em 1985 (ABREU, 2003a, p. 83-84). 
Um exemplo bem sucedido no mundo ocidental é a França. Em 1994, o Ministério da Cultura deste país concedeu o título de "Tesouros humanos vivos" a quase vinte pessoas, consideradas "mestres da arte". A estes mestres, para a preservação dos saberes, caberia "transmitir sua técnica a um aluno escolhido, na busca de perenização do seu ofício" (ABREU, 2003a, p. 85). Segundo a autora, os detentores deste "saber-fazer" podem ser chapeleiros, costureiros, restauradores, desde que a preservação de suas competências, muitas delas desenvolvidas ao longo de séculos, seja de interesse da nação francesa. E pelo o que se pode perceber do projeto, a transmissão do conhecimento é a melhor forma de preservação (ABREU, 2003a, p. 86-87).

Deste modo, retornando à realidade brasileira, podemos observar a preocupação com as manifestações e expressões culturais já no anteprojeto de Mário de Andrade, reformulado para a criação do Decreto-Lei n ${ }^{0} 25$ de 1937, nos discursos de Aloísio Magalhães e na Constituição Federal de 1988; porém, dos discursos para as práticas, encontramos mudanças principalmente após o Decreto $\mathrm{n}^{\mathrm{o}} 3.551$ de 2000, referente ao patrimônio imaterial, o que implica enfatizar a necessidade, seja pelo pouco tempo destas transformações quanto pela manutenção de instrumentos insuficientes, de novas pesquisas e ações para que o patrimônio cultural brasileiro, móvel ou imóvel, material ou imaterial, melhor preserve, transmita e represente a diversidade cultural do país.

\subsection{O Brasil e as instituições internacionais}

Como vimos nos exemplos provenientes do mundo asiático, uma revisão do conceito de patrimônio não foi uma exclusividade do Brasil. Ela se insere em um conjunto de discussões que se iniciaram com a criação da UNESCO em 1945 e que ganharam força na década de 1970. Desta forma, reconhecemos que, apesar de terem sido importantes, as mudanças políticas e sociais no Brasil ao longo do século XX não foram as únicas razões pelas quais a concepção de patrimônio adotada por Aloísio Magalhães se opôs a da Rodrigo M. F. de Andrade, mas também as transformações nas instituições culturais internacionais, que buscavam formas de valorizar as expressões culturais dos países em desenvolvimento e subdesenvolvidos sem deixar de atender os interesses dos países desenvolvidos, que até então privilegiavam uma política patrimonial voltada para a arquitetura.

Foi na França pós-Revolução que o sentido de patrimônio como construção física começou a se estabelecer institucionalmente. Em 1837, na primeira Comissão dos Monumentos Históricos, as obras foram dividas em três grandes categorias: remanescentes da 
Antiguidade, edifícios religiosos da Idade Média e castelos (CHOAY, 2006, p.12). Depois disto, ao longo do século XIX e parte do XX, período marcado por uma grande preocupação com a preservação e restauração, o que se verificou foi apenas uma ampliação dos bens passíveis de serem considerados patrimoniais, enquanto o próprio conceito não foi questionado.

Um exemplo é a Carta de Veneza de 1964. Utilizada como um parâmetro para as políticas nacionais durante o século $\mathrm{XX}$, o documento apenas lista um conjunto de construções que são consideradas monumentos históricos, enquanto a expressão "significação cultural", citada no texto, não é desenvolvida ou explicada. Para a Carta, o conceito de monumento histórico compreenderia “a criação arquitetônica isolada, bem como o sítio urbano ou rural que dá testemunho de uma civilização particular, de uma evolução significativa ou de um acontecimento histórico" (ICOMOS, 1964 p. 1-2). Um avanço em relação às resoluções anteriores foi excluir o requisito de grandiosidade para um bem ser preservado, abrangendo para a possibilidade de incluir o que ela denomina de "obras modestas"; entretanto, uma problematização sobre como uma obra se transforma em um testemunho histórico e adquire determinados sentidos para uma sociedade não ocorre, mas reforçam-se as preocupações com a conservação e restauração da construção em si, recomendando, no máximo, que os relatórios produzidos pelos técnicos fossem publicados para a consulta por pesquisadores.

Segundo Smith (2008, p. 11), os documentos, comissões, relatórios, cartas elaborados desde a Revolução Francesa produziram o que ela identifica como o "discurso patrimonial autorizado", que consiste em privilegiar a monumentalidade, ancianidade, materialidade, os valores históricos, artísticos, técnicos/ científicos e o consenso nacional de uma obra.

O resultado foi a produção de narrativas nacionais baseadas nos valores dos grupos dominantes, que se legitimam, por um lado, pela grandiosidade, permanência/ materialidade e erudição de suas construções e, por outro, pela dificuldade dos grupos subalternos em valorizar e divulgar outros critérios de reconhecimento de um bem além daqueles já sedimentados pela história oficial e técnicos autorizados. Deste modo, não é difícil encontrarmos os considerados patrimônios de um país como um reflexo da cultura de determinado grupo, enquanto os demais são esquecidos e negligenciados. No Brasil, como discutimos neste capítulo, o que se viu foi a descrição de um país herdeiro da cultura 
europeia, católico e branco, empenhado para que os demais estratos sociais fossem educados para conhecer e compreender a nossa identidade ${ }^{11}$.

A partir da evidência, verificável nas listas patrimoniais, de que os critérios utilizados favoreciam a produção cultural de determinados países, principalmente europeus, em detrimento daqueles vistos como subdesenvolvidos e pós-coloniais, além da preocupação cada vez maior com os efeitos da globalização sobre manifestações locais, regionais e mesmo nacionais, alguns países começaram a questionar e sugerir, com maior ênfase a partir da década de 1970, mudanças nas concepções dominantes até então adotadas pela UNESCO. A Bolívia, por exemplo, em 1973, solicitou à instituição que o folclore também fosse protegido por copyright, o que não foi aceito por não ter sido considerado o instrumento adequado ${ }^{12}$ (AIKAWA, 2004).

O surgimento de novas tecnologias de informação e comunicação nas últimas décadas aliado à desregulamentação de alguns mercados nacionais fortaleceu as indústrias culturais dos países ricos e aumentou a demanda por produtos desses mercados, como o fonográfico e cinematográfico. Com receio de uma homogeneização e padronização cultural provocada pelo aumento do consumo de bens estrangeiros em substituição às produções locais, nações da América Latina, Ásia e África insistiram com maior frequência pelo estabelecimento da ideia de diversidade cultural (ALVES, 2009, p. 174).

Como fruto dessas discussões que questionavam o desequilíbrio das políticas patrimoniais, em 1972 a UNESCO publicou a Recomendação de Paris sobre a Proteção do Patrimônio Mundial, Cultural e Natural. No documento, ao contrário da escala nacional, o que se destaca é a importância que uma obra pode ter além das fronteiras de um país, sugerindo ser uma necessidade os Estados se empenharem para proteger o patrimônio cultural até mesmo das nações que não possuem todos os recursos e condições suficientes para preserválo. Ainda, apresenta uma definição de patrimônio natural e defende sua preservação, permitindo o envio de recursos para a manutenção de formações físicas e geológicas, muitas delas presentes em locais sem grandes construções arquitetônicas ou obras de arte. De acordo com Sant'anna (2003, p. 50), nesse ambiente de reformulação, logo após a aprovação da Convenção, países subdesenvolvidos solicitaram a realização de estudos para a elaboração, no

\footnotetext{
${ }^{11}$ Como citado anteriormente, os países asiáticos nunca utilizaram esses critérios para a seleção de seus patrimônios culturais. Pelo contrário, em países com Japão, Coréia e Filipinas, o valorizado é a transmissão de um saber e não os seus objetos e construções. No entanto, essa concepção não foi considerada no Ocidente até a década de 1970, não influenciando nas políticas inclusive do Brasil.

${ }^{12} \mathrm{Na}$ década de 1950, discussões multilaterais já consideravam a idéia do copyright para o folclore e a cultura tradicional. O objetivo era garantir a continuidade de determinadas manifestações e destinar recursos financeiros para os seus criadores/praticantes (KURIN, 2004, p. 67).
} 
âmbito internacional, de um instrumento de proteção das manifestações populares de valor cultural, o que foi possível somente em 1989.

Nesse ano, publicou-se a Recomendação de Paris sobre a Salvaguarda da Cultura Tradicional e Popular ${ }^{13}$, antevendo uma concepção de patrimônio que também valoriza as produções de grupos populares, mesmo as que dependem da tradição oral e correm riscos de desaparecer. Como mecanismo de conservação, institui a documentação dessas tradições, depositando os registros em museus, arquivos e bibliotecas que os divulgariam. Outro meio de difusão seria incluir nos programas de ensino escolar o estudo desses grupos e sua cultura, dando ênfase para a diversidade cultural e as diferentes visões de mundo, "especialmente as que não participem da cultura dominante" (UNESCO, 1989, p. 4).

Nesse momento, novamente encontramos a divisão entre discurso e ação aqui apresentada. Apesar de ampliar a categoria de bens que poderiam ser preservados e valorizados nacionalmente, incluindo, de certa forma, o que posteriormente seria denominado patrimônio intangível, pouca coisa foi feita e por poucos países (KURIN, 2004, p. 68). O texto é apenas uma recomendação, sem o compromisso dos países em realizar alguma mudança em suas políticas, o que realmente não aconteceu.

O Brasil foi um dos poucos que instituiu uma legislação específica que garantia a proteção desses bens. Influenciado por discussões lideradas por Aloísio Magalhães desde a década de 1970, a atual Constituição Federal e alguns congressos, em 2000 publicou o Decreto $\mathrm{n}^{\mathrm{o}} 3.551$, que criou o programa nacional do patrimônio imaterial e instituiu o registro dos bens culturais de natureza imaterial. Segundo Fonseca (2004, p. 172), podemos considerar o Brasil como um pioneiro nas questões patrimoniais, pois foi o primeiro país latinoamericano a estabelecer uma legislação para a proteção do patrimônio histórico e artístico em 1937 e um dos primeiros, se considerarmos apenas o mundo ocidental, em criar instrumentos para a preservação do seu patrimônio intangível.

No âmbito mundial, um comprometimento com o patrimônio intangível foi alcançado apenas em 2003, quando foi aprovada a Convenção para a Salvaguarda do Patrimônio Cultural Imaterial. A partir de então, a UNESCO não somente recomendou uma política, mas

\footnotetext{
${ }^{13}$ Segundo a Recomendação (1989, p. 2), “A cultura tradicional e popular é o conjunto de criações que emanam de uma comunidade cultural fundadas na tradição, expressas por um grupo ou por indivíduos e que reconhecidamente respondem às expectativas da comunidade enquanto expressão de sua identidade cultural e social; as normas e os valores se transmitem oralmente, por limitação ou de outras maneiras. Suas formas compreendem, entre outras, a língua, a literatura, a música, a dança, os jogos, a mitologia, os rituais, os costumes, o artesanato, a arquitetura e outras artes".
} 
os países signatários deveriam se esforçar para cumprir o texto aprovado e destinar regularmente recursos para um "Fundo para a Salvaguarda do Patrimônio Cultural Imaterial".

O acordo para sua aprovação resultou de anos de discussões sobre o tema. Em 1992, a UNESCO já tinha criado um programa chamado "Patrimônio Cultural Intangível” para o desenvolvimento de um novo conceito de patrimônio, permitindo que, em 1993, fosse lançado o projeto "Tesouros Humanos Vivos"; em 1997, a Proclamação das Obras Primas do Patrimônio Oral e Intangível da Humanidade, com sua primeira lista publicada em 2001; mesmo ano da Declaração Universal Sobre a Diversidade Cultural (AIKAWA, 2004).

A maior preocupação de especialistas e teóricos desde 1989 e, principalmente 1992, era com o conceito de patrimônio intangível. Apesar de considerarem a Recomendação de 1989 insuficiente por privilegiar a documentação e preservação de registros de tradições em perigo ao invés de focar na promoção e continuidade destas pelos seus praticantes (KIRSHENBLATT-GIMBLETT, 2004, p. 53), o maior empecilho para o sucesso de determinadas ações parece ter sido definir esse tipo de patrimônio.

O observado é que a noção de patrimônio imaterial está muito próxima da de tradições populares (ALVES, 2009, p. 189). Por um lado, porque os objetos provenientes dessas tradições não se enquadram nas exigências e requisitos do discurso patrimonial autorizado, privilegiando a proteção somente daquilo que é visto como intangível. Depois, porque essa nova ideia de patrimônio está fortemente influenciada por um viés antropológico, que trabalha com uma concepção ampla de diversidade e cultura, favorecendo a inclusão dessas práticas no debate patrimonial.

De acordo com Kurin (2004, p. 67), em um contexto internacional, encontram-se expressões como folclore, patrimônio oral, cultura tradicional, cultura expressiva, modo de vida, folklife, cultura etnográfica, comunidade baseada na cultura, costumes, patrimônio cultural vivo e cultura popular para expressar, muitas vezes, a mesma coisa. Deste modo, para a Convenção de 2003, considerou-se uma pesquisa realizada pela UNESCO no início da década de 1990 que pretendeu levantar as diferentes definições de patrimônio cultural intangível utilizadas pelos Estados membros, organizações governamentais e nãogovernamentais (AIKAWA, 2004, p. 142).

Segundo a Convenção,

Entende-se por "patrimônio cultural imaterial" as práticas, representações, expressões, conhecimentos e técnicas - junto com os instrumentos, objetos, artefatos e lugares que lhes são associados - que as comunidades, os grupos e, em alguns casos os indivíduos reconhecem como parte integrante de seu patrimônio cultural. 
Esse patrimônio cultural imaterial, que se transmite de geração em geração, é constantemente recriado pelas comunidades e grupos em função de seu ambiente, de sua interação com a natureza e de sua história, gerando um sentimento de identidade e continuidade, contribuindo assim para promover o respeito à diversidade cultural $\mathrm{e}$ à criatividade humana (UNESCO, 2003, p. 2-3).

Abrangente, a Convenção não se caracteriza por um conjunto de regras rígidas, mas permite sua aplicação de acordo com as especificidades de cada país (BEDJAOUI, 2004, p. 151). De modo inclusivo, estimula que a salvaguarda do patrimônio intangível seja integrada com outras intervenções estatais, como planos de desenvolvimento, pesquisas científicas, instituições e leis locais, além de cooperação internacional. Tal concepção existe, pois para a Convenção não é a UNESCO ou o Estado que deve determinar como proteger os bens intangíveis, em uma decisão unilateral, de cima para baixo, mas são os praticantes os principais responsáveis pela sua continuidade, em parceria com essas instituições (KURIN, 2004, p. 72-73).

Desta forma, a Convenção renova e acrescenta informações à Recomendação de 1989. Para Aikawa (2004, p. 146), ela compreende o patrimônio como um processo e não seus produtos; o reconhece como fonte de identidade, diversidade e transmissão de um conhecimento; solicita a participação de seus praticantes/criadores na sua salvaguarda e o considera, para as políticas adotadas, a partir de seu ambiente e sociedade que o pratica/realiza.

Nesse sentido, ao longo das quatro últimas décadas, a UNESCO e alguns países, inclusive o Brasil, tem feito esforços para ampliar a noção de patrimônio cultural, mas que ainda são incipientes devido ao pouco tempo de algumas resoluções e pela dificuldade em superar o sentido dominante de patrimônio como uma coisa, que se auto-explicaria em sua materialidade, utilizado por alguns técnicos e fortemente enraizado no senso comum.

Portanto, nesta dissertação, defenderemos uma ideia ampla de patrimônio cultural, na tentativa de não reproduzir discursos dominantes que foram sustentados ao longo da história e que garantem a identificação, preservação, valorização e promoção de apenas um conjunto de bens.

Consideramos importante mostrar esse quadro histórico, pois é a partir dele que entendemos as discussões atuais sobre o patrimônio cultural, as justificativas de preservação e os valores atribuídos a uma obra considerada relevante para a memória e identidade de 
determinados grupos ou mesmo de toda a nação. Especificamente nesta pesquisa, o nosso objetivo foi compreender como ocorre a apropriação do patrimônio cultural em uma escala diferente do nacional, no caso, em uma pequena cidade do interior do Estado de São Paulo, Santa Rosa de Viterbo. Para tanto, realizamos encontros com moradores da cidade, principalmente com os que se interessam ou estão envolvidos com a área cultural, para a produção de textos que abordam diferentes visões sobre o município e seus possíveis patrimônios. Com isso, esperamos que a população participante refletisse sobre a cidade e seus bens culturais, auxiliada por uma metodologia de aproximação entre as políticas oficiais e percepções cotidianas, discussões teóricas e vida prática, o global e o local. Posteriormente, além de apontar o que parte dos moradores entende por patrimônio cultural, analisaremos como ele é construído discursivamente, contribuindo tanto para novas abordagens sobre os usos do patrimônio como para um maior protagonismo dos habitantes relacionados ao projeto nas questões que envolvem a cultura de sua cidade. 


\section{A CIDADE COMO LUGAR DE MEMÓRIA: MEDIAÇÕES PARA A APROPRIAÇÃO SIMBÓLICA E O PROTAGONISMO CULTURAL EM SANTA ROSA DE VITERBO}

Neste capítulo, pretendemos apresentar os referenciais teóricos e empíricos que utilizamos para a aplicação de entrevistas e sua posterior discussão por meio das transcrições realizadas. Nesse momento, nosso intuito foi estabelecer critérios para o estabelecimento de uma relação com os entrevistados que possibilitasse um estado de confiança mútua e a manutenção do contato inicial, permitindo uma efetiva participação desses moradores no processo de elaboração da dissertação. Ao mesmo tempo, questionamos a possibilidade de autonomia interpretativa do indivíduo na análise da cidade a partir de sua memória individual e compartilhada, não apenas reproduzindo quadros sociais legitimados que restringiriam sua capacidade de crítica e apropriação do patrimônio cultural local.

\subsection{Memória}

Ao pedirmos para alguém falar sobre sua trajetória de vida, de uma sociedade, do lugar onde cresceu, ela recorre à memória para temporalizar os eventos e significá-los segundo suas emoções e sentimentos. Porém, essa memória não é resultado apenas de experiências individuais, mas do meio social no qual ela se desenvolveu, participando de uma rede de disputas que pode ou não ser reconhecida por este e outros grupos.

Podemos dizer que ela é fortemente marcada pelas relações sociais e grupos nos quais nos inserimos. Provavelmente, foi essa a maior contribuição de Maurice Halbwachs (2004, p. 58) ao defender que "um homem, para evocar seu próprio passado, tem frequentemente necessidade de fazer apelo às lembranças dos outros", e, portanto, ao pedirmos para alguém falar do passado, também damos voz à comunidade na qual essa pessoa vive, que interfere na sua construção do social (BOSI, 2003, p. 54).

Para Gondar e Dodebei (2005, p. 17), além de uma construção individual, a lembrança é uma montagem da sociedade que a produziu e daquelas nas quais continuou a existir. Assim sendo, uma interpretação é que parte das nossas lembranças já existiria antes mesmo do nosso nascimento, o que, à primeira vista, nos transmite a ideia de ausência de autonomia. 
Ainda, quando as memórias analisadas são aquelas estimuladas por uma entrevista, também devemos considerar possíveis limitações de espontaneidade, pois para cada interlocutor/ ouvinte, o entrevistado assume um discurso com o objetivo de transmitir determinada mensagem, de acordo com o que ela considera correto, isento, imparcial, culto, etc. Ao levarmos em conta esta situação, quando instauramos um diálogo com a intenção de recolher relatos para uma pesquisa, devemos considerar que o que foi dito pelo entrevistado foi em um contexto não natural, no qual ele sabe que não ficará restrito apenas àquele momento, mas que é passível de ser divulgado e ouvido/ lido por pessoas que ele nem mesmo conhece, ou seja, de fora do seu círculo de confiança e intimidade.

Desta forma, algumas perguntas são relevantes na tentativa de entender quais os possíveis efeitos desse diálogo instituído com o entrevistado: aquele que conta pode tirar algum proveito da ação de questionar o passado a partir do presente? Em que medida, enquanto ser social, ele é autônomo em suas opiniões? Será que ele apenas reproduz representações de uma coletividade?

Para alguns autores, fazer parte do social não significa reduzir o indivíduo apenas em reflexo do coletivo. O indivíduo é membro dessa negociação de sentidos, e ao mesmo tempo em que reproduz, também é criador. Como observa Certeau (2004), se há uma disciplina, uma ordem, coexistem maneiras de fazer que impossibilitam a homogeneidade.

Analisando as teorias de William Wordsworth e Sigmund Freud, Assmann (2007, p. 115) destaca, entre outras coisas, que a memória não é somente um ato de registrar-conservarrecuperar. Ela é sempre uma nova criação e, por conseguinte, o recordar é um processo ativo que permite uma nova percepção.

Marcuse que, junto com outros teóricos da Escola de Frankfurt, como Adorno e Horkheimer, apontou a alienação e perda de autonomia do indivíduo perante a sociedade de massa, acreditava que a memória é capaz de ultrapassar a repressão, pois a interpretava como uma condição inerente ao sujeito, enquanto o social seria apenas um tipo de construção da memória, diferente, por exemplo, dos impulsos da infância que não foram rompidos pela esfera coletiva (SANTOS, 2009, p. 93-113).

Não enfatizar esse processo de individualização é a principal crítica à teoria de Halbwachs. Apesar de perceber que cada indivíduo utiliza a memória de maneiras diferentes, ele a explica por quadros sociais, estruturas que o antecedem, negando, por exemplo, o papel dos sentimentos, julgamentos e experiências pessoais. Segundo sua teoria, as memórias individuais seriam apenas combinações aleatórias de memórias coletivas (SANTOS, 2002, p. 151-155). Deste modo, por negar a existência de atores sociais, como salienta Ricoeur (2010, 
p. 132), e consciência individual, ou seja, a capacidade de percepção e julgamento do mundo interior e exterior, recorremos também a autores como Walter Benjamin, que apresentam outros caminhos para pensar a memória.

Ao contrário de Halbwachs, as pesquisas que utilizam entrevistas, como a nossa, reforçam o papel do indivíduo, que mesmo inserido no coletivo, não se dissolve nele. Para Portelli (1998, p. 127), "se toda memória fosse coletiva, bastaria uma testemunha para uma cultura inteira". Portanto, é necessário dar ênfase às maneiras pelas quais cada indivíduo organiza e dá sentido a essas memórias coletivas e à sua própria história. Nesta perspectiva, a memória continua social, mas reconhecemos que ela só "se materializa nas reminiscências e discursos individuais" (PORTELLI, 1998, p. 127).

De modo geral, nessas pesquisas, não se objetiva mostrar a percepção do coletivo, como uma síntese, uma voz única, mas expor as semelhanças individuais que reforçam a ideia de traços comuns, a vida inserida no social, sem negar o característico do singular. Por isso a importância de transcrever, inserir no texto e dar nomes a cada entrevistado, porque

o que se chama de "grupal", "cultural", "social" ou "coletivo" [...] é o resultado de experiências que vinculam umas pessoas às outras, segundo pressupostos articuladores de construção de identidades decorrentes de suas memórias expressadas em termos comunitários (MEIHY; HOLANDA, 2007, p. 27).

Uma das explicações para essa individualização é as nossas emoções. Como sabemos, a memória é seletiva. Ela não é um depósito no qual podemos preservar todas as nossas experiências e recuperá-las quando desejarmos. Entre todos os estímulos que recebemos, apenas alguns se transformarão, por meio dos nossos sentimentos e afetividade, em traços mnemônicos capazes de interferir em nossa visão do passado (GONDAR, 2000, p. 36).

Segundo Markowitsch (2009), possuímos cinco principais sistemas de memória de longo prazo: memória de procedimento, mais comumente chamada de memória-hábito; memória implícita, referente à capacidade de reconhecer informações previamente percebidas; memória perceptiva, para o reconhecimento de estímulos; memória semântica, referente ao conhecimento e, por fim, memória episódica, que garante, por meio das emoções, destacar momentos vividos perante todos os demais. É partir dela que construímos nossa biografia, determinamos nossa personalidade e nos diferenciamos como indivíduos.

Mesmo todo indivíduo sendo membro e influenciado pela sociedade, sua capacidade de crítica e reflexão continua a existir pela própria instabilidade do social. Não há uma 
memória coletiva que nos unifica e organiza. O que existe são memórias compartilhadas que estão a todo o tempo em conflito, movimento e modificação em resposta a atitudes singulares. Assim, se o social pode ser coercivo, a confrontação de diferentes memórias permite questionamentos e escolhas, mostrando o indivíduo como parte do coletivo e não como seu resultado.

Ao considerarmos, portanto, que a memória não se explica apenas pela oposição entre quadros sociais e autonomia individual, mas por interseções que se apresentam em diferentes níveis, a diferenciação entre memória voluntária e involuntária contribui para melhor compreender as características do ato de lembrar na e em sociedade. Walter Benjamin observa que, enquanto a memória voluntária é aquela que resulta de uma ação intencional de quem lembra, a involuntária é espontânea, natural, sem uma ação planejada, prevista. Deste modo, esses dois tipos de memória, que também podem ser denominados de lembrança (voluntária) e reminiscência (involuntária), nos mostram duas possibilidades de compreensão do mundo (SANTOS, 2009, p. 141-144).

Nesta dualidade, seria possível afirmar que estamos em constante contato com o passado, pois, mesmo se não desejamos, existe a memória involuntária que não permitiria quebrar esse vínculo com os acontecimentos anteriores. Ainda, indo um pouco mais longe, a ideia de que uma pesquisa baseada em relatos orais contribui para que seus participantes entrevistados façam uma reflexão sobre o passado seria apenas mais uma possibilidade, pois sempre poderíamos defrontá-lo pela presença de estímulos involuntários.

Porém, tanto Walter Benjamin como Hannah Arendt acreditam que a memória involuntária ou espontânea, na modernidade, só é possível em um estado de exceção. Para Arendt (2007, p. 54), revoluções, como a Francesa e Industrial, catástrofes, como as duas Grandes Guerras, entre outras condições do período, levaram a uma quebra entre o passado e o futuro que deixou a sociedade sem uma referência para compreender a nossa herança. Assim, sem memória involuntária ou, nas palavras de Arendt, sem tradição, o passado não teria mais sentido.

O testamento, dizendo ao herdeiro o que será seu de direito, lega posses de um passado para um futuro. Sem testamento, ou, resolvendo a metáfora, sem tradição que selecione e nomeie, que transmita e preserve, que indique onde se encontram os tesouros e qual o seu valor - parece não haver nenhuma continuidade consciente no tempo, e portanto, humanamente falando, nem passado nem futuro, mas tão-somente e sempiterna mudança do mundo e o ciclo biológico das criaturas que nele vivem (ARENDT, 2007, p. 31). 
Benjamin é da mesma opinião de Arendt ao dizer que, na cidade moderna, a memória não é mais capaz de trazer conhecimento, explicar nossas experiências e dar um significado à vida. Para ele, reduzidos apenas a uma memória voluntária fragmentada, somos incapazes de alcançar o que não está latente, tornando-nos reféns do mercado e das relações de poder, restringindo ou mesmo anulando nossa liberdade e capacidade de crítica (SANTOS, 2009, p. 144).

A memória involuntária continuaria a existir, mas apenas excepcionalmente e por meios artificiais, como mostrou Proust em sua obra "Em busca do tempo perdido", analisada por Benjamin (2008). Na passagem mais conhecida do clássico francês, o protagonista Marcel, que praticamente não preservava lembranças de sua cidade natal, Combray, recordase de sua infância ao experimentar o doce madeleine:

\begin{abstract}
E de súbito a lembrança me apareceu. Aquele gosto era o do pedaço de madalena que nos domingos de manhã em Combray (pois nos domingos eu não saía antes da hora da missa) minha tinha Léonie me oferecia, depois de o ter mergulhado em seu chá da Índia ou tília, quando ia cumprimentá-la em seu quarto. O simples fato de ver a madalena não me havia evocado coisa alguma antes que a provasse; talvez porque, como depois tinha visto muitas, sem as comer, nas confeitarias, sua imagem deixara aqueles dias de Combray para se ligar a outros mais recentes; talvez porque, daquelas lembranças abandonadas por tanto tempo fora da memória, nada sobrevivia, tudo se desagregara; as formas - e também a daquela conchinha de pastelaria, tão generosamente sensual sob sua plissagem severa e devota - se haviam anulado ou então, adormecidas tinham perdido a força de expansão que lhes permitiria alcançar a consciência (PROUST, 2007, p. 73).
\end{abstract}

Portanto, de acordo com concepções de Benjamin e Arendt, restar-nos-ia apenas a memória voluntária? Nem isso. Sem tradição e perdidos no que hoje chamamos de Sociedade da Informação, qualquer capacidade de interpretar o passado ficaria comprometida. Agora, quando nossa olhar se dirige a ele, não contaríamos mais com pontos fixos para nos situarmos, mas sempre precisaríamos criar uma nova imagem, o que, como mostrou Arendt (2007, p. 56), também tem seu lado positivo, pela possibilidade de uma "visada direta", não obstruída por nenhuma autoridade.

Foi nessa perspectiva que Nora $(1993$, p.7) afirmou que "fala-se tanto de memória porque ela não existe mais". Para ele, a construção de lugares de memória é uma tentativa de dar um sentido de continuidade onde só há ruptura. Assim, só nos restaria aquilo que chamamos de patrimônio cultural em uma perspectiva negativa, ou seja, vestígios que tentam reconciliar passado e presente sem sucesso, pois a vida do homem perdeu o seu sentido. 
Como Benjamin (2008, p. 115) questiona, (...) "qual o valor de todo o nosso patrimônio cultural, se a experiência não mais o vincula a nós?"14.

Isolado, sem referências para agir na cidade moderna, o homem só possuiria a memória de sua própria vivência (erlebnis), podendo falar apenas dos acontecimentos que presenciou, diferente daquele que, inserido em uma comunidade, acumula saberes que percorrem gerações (erfahrung) (BENJAMIN, 2008).

A erlebnis é caracterizada pela provisoriedade, pela necessidade de estar vivo quando um evento acontece, expondo a fragilidade da ligação entre passado e presente. Contar apenas com a erlebnis impossibilita de recorrer à tradição, restringindo o nosso conhecimento somente ao que é fugaz, à avalanche de informações que recebemos diariamente, as quais, descontextualizadas, não adquirem sentidos que ultrapassam o imediato (MEINERZ, 2008, p. 17-18).

Já a erfahrung, ao contrário, é adquirida pela vida em comunidade, na qual entre cada geração encontramos continuidade. Assim, não aprendemos apenas quando estamos presentes, pois os conhecimentos se acumulam e influenciam no dia-a-dia daqueles que estão vinculados a um passado compartilhado. Podemos dizer que a erfahrung é o que permite uma memória de longa duração.

Sem essa memória, o homem moderno teria perdido a capacidade de contar histórias. O que se diz hoje não duraria mais que uma geração, pois na seguinte, o que foi transmitido não é mais compartilhado entre transmissor e receptor, pela inexistência de traços comuns que garantem o interesse e utilidade do foi contado. Para Benjamin (2008, p. 119), ficamos pobres de experiência. "Abandonamos uma depois da outra todas as peças do patrimônio humano, tivemos que empenhá-las muitas vezes a um centésimo do seu valor para recebermos em troca a moeda miúda do 'atual' ".

Também segundo Benjamin (2008), ser um narrador não é transmitir uma informação explicando-a, como um jornalista imparcial, mas saber imergir na sua experiência e na alheia para dar um conselho, um ensinamento, que ao invés de explicar algo, é útil para a vida. Deste modo, sua crítica recai sobre o excesso de informações no mundo moderno, que, ao se dirigir a todos e ninguém ao mesmo tempo, não carrega os sentimentos que garantem a sua reprodução.

\footnotetext{
${ }^{14}$ Segundo Hartog (2006), o patrimônio é uma maneira de viver o tempo de crise, um desejo de desenvolver vínculos ao mesmo tempo em que é um sinal de perda. Desta forma, toda a corrida pela "patrimonialização" demonstraria uma preocupação com o futuro, pois ele se apresenta como ameaça quando vivemos em uma época de amnésia.
} 
Seu pensamento tenta mostrar o fim da vida em comunidade, que, para Halbwachs (2004), é o que sustenta a memória coletiva. Enquanto para este autor a nossa memória se constituiu no convívio com o grupo no qual pertencemos espacial e temporalmente, para Benjamin (2008), o destino do homem moderno é o isolamento, ao esfacelarem-se as relações que garantiam nossa identidade perante as transformações mundanas. Assim, "todas as três comunidades de memória (nação, grupo étnico e família) são afetadas pelo crescimento da diferenciação da sociedade, globalização do mundo e pelo desenvolvimento dos novos meios de comunicação" (MISZTAL, 2007, p. 388, tradução nossa).

Nesta leitura, concluiríamos que a utilização de entrevistas para uma análise da memória social seria limitada e restrita, pela incapacidade de ultrapassar as experiências da nossa geração e lembrar além do pouco que nos restou. No entanto, nossa concepção se baseia não no fim da memória, mas na existência de diferentes vivências sociais que possibilitam novas relações espaços-temporais. Esse é o intuito, por exemplo, de Landsberg (2004), na tentativa de mostrar a importância de experiências e memórias "inautênticas", como as originárias da cultura de massa.

Valendo-se de filmes, museus, livros, Landsberg (2004) questiona os limites tradicionalmente aceitos para a existência de memórias e afirma que hoje é representativa a sua formação além de contextos sociais vividos. Para o autor, ao contrário de produzir uma amnésia coletiva, a cultura de massa estimula o desenvolvimento de memórias artificiais e protéticas (prosthetic memory). Desta forma, construiríamos laços fortes com um passado distante mesmo quando ele não foi presenciado pela nossa geração. É o reconhecimento de comunidades imaginadas que ao compartilharem os mesmos produtos culturais estabelecem pontos de contato entre distantes (ANDERSON, 2008). Assim, as memórias protéticas nunca se restringem a uma única pessoa, mas há uma grande probabilidade de milhares assistirem ao mesmo filme, lerem o mesmo livro, etc.

Possivelmente, Benjamin defenderia que essas memórias não são autênticas, como reconhece Landsberg, e podem ser utilizadas como um instrumento de poder. Por outro lado, elas também revelam que comunidades e compartilhamentos continuam a existir. Ainda, como citamos anteriormente, os indivíduos não recebem essas memórias, necessariamente, de forma passiva, podendo ressignificá-las de acordo com os seus interesses e contextos, ao contrário de levar à alienação. Neste quadro, o passado segue a despertar interesse das pessoas e mesmo que não seja mais alcançado como tradição, ainda é uma referência para as nossas ações no presente. É por isso que acreditamos que as pessoas ainda têm o que contar e que há conexões entre o que elas dizem. As mudanças apontadas por Benjamin e Arendt são 
esclarecedoras, entretanto não significam o fim do testemunho, mas uma transformação que deve ser considerada.

Ao narrar sua vida inserida no social, o entrevistado a ordena para dar a ela um sentido. Sua história adquire uma unidade, que mesmo ilusória, proporciona-lhe parâmetros para a reflexão e ação. Organizando suas experiências pela narrativa e elaborando o que deseja transmitir aos outros, o entrevistado alcança condições para a crítica do que na realidade é complexo e transitório.

(...) essa é precisamente a qualidade da narrativa, que opera, performativamente, na construção de algo que como tal não existe em outra parte fora do relato: a distância insalvável entre a "vida" - como amontoado de experiências heteróclitas, temporalidades disjuntas, sensações, pulsões, memórias - e a organização forçada que impõe o discurso, tomado este em sua mais ampla acepção (ARFUCH, 2009, p. 117).

A partir dessa unidade, constitui-se uma identidade narrativa. Ao contar e compartilhar algo com alguém que escuta, questiona, confirma ou nega, o indivíduo se insere em uma temporalidade própria, na qual ele se localiza e se reconhece. Mais consciente do seu papel e da importância que atribui ao que ocorre ao seu entorno, aumenta a sua capacidade de discernimento, permitindo um estado de maior autonomia. Assim, narrar, principalmente na autobiografia, se configura em uma busca constante de conhecimento sobre o eu, o outro e a sociedade (STRAUB, 2009, p. 83-84).

Entendemos que os indivíduos participam dos conflitos e embates pela formação de uma memória coletiva, mas que nunca será alcançada devido à impossibilidade de um consenso ou dominação total. Mesmo compartilhando ideias, suas memórias, carregadas de emoções, sempre serão, ao mesmo tempo, singulares e inter-relacionadas. Portanto, ao dar voz para uma pessoa se expressar, permitimos não somente que ela apresente as percepções e representações dos grupos aos quais ela se insere, mas também como ela interpreta e utiliza essas referências e interferências do social em sua experiência particular.

Ao invés de sustentar a concepção de um isolamento do homem moderno, que sem tradição perderia os laços com o passado, acreditamos que a modernidade permitiu o surgimento de novas experiências, e, por meio delas, a possibilidade de se conectar com diferentes "passados imaginados". Diante de tantas opções, falar sobre a nossa biografia, o que pensamos ter acontecido e como vemos o mundo nos auxilia a ordenar e pensar sobre 
essas reconstruções e determinar o que consideramos merecedor de valorização, questionamento ou esquecimento.

Bauman (2005) utiliza a metáfora de um quebra-cabeça para exemplificar sua concepção de identidade na "modernidade líquida". Para o autor, a identidade é como um conjunto de peças de montar incompleto ou infinito, até porque, para garantir a nossa liberdade de escolha, nunca queremos finalizá-lo e fechar a porta para outras possibilidades de montagens. Desta maneira, sempre estamos mexendo nesse conjunto, juntando e tirando peças, trocando outras de lugar, o que mostraria o caráter transitório e movente de nossa identidade no tempo presente.

Valendo-se dessa metáfora, em vez de defendermos que instigar uma reflexão sobre o passado reforça a nossa identidade e sentimento de pertencimento, sugerimos que esse ato permite que alguns conjuntos sejam visualizados e discutidos, o que não muda nem o número de peças nem as alternativas para outras combinações, mas nos deixa mais conscientes de nossas escolhas e capazes para a crítica e ação na sociedade.

Somos seres sociais e nossa memória se constitui no convívio em sociedade. No entanto, é necessário complementar que o coletivo não é uma entidade pré-existente, mas um recurso teórico para mostrar os compartilhamentos entre indivíduos singulares. Porém, a recorrência constante ao que é comum reforça a ilusão de inexistência da diferença, mascarando as experiências pessoais que garantem o poder de criação e questionamento a cada um.

Convencidos disto, acreditamos que ao falar sobre suas opiniões e trajetória de vida, o entrevistado não apenas reproduz o que é legitimado socialmente, mas se vê diante de uma oportunidade para refletir sobre as suas percepções, representações e sentimentos. Além disso, o ato de contar permite a constituição de uma identidade narrativa, ordenando os eventos que por natureza são sobrepostos. Assim, mais fácil será saber, defender ou rever quem somos, o que pensamos e queremos, reconhecendo, inclusive, o papel exercido por uma memória cultural de longa duração.

A partir do entendimento de que o indivíduo pode contribuir com uma abordagem crítica e reflexiva, desenvolvemos a ideia de uma pesquisa participativa, na qual, no nosso caso, os entrevistados acompanharam e puderam interferir no andamento do projeto. Aqueles com quem conversamos não foram vistos como informantes passivos, mas como sujeitos que podiam contribuir para a nossa reflexão, sugerindo mudanças e questionando as nossas análises e descrições. Para isto, uma das principais técnicas utilizadas foi a do retorno do material produzido. Sempre que transcrevemos uma entrevista ou produzimos um texto a 
partir das opiniões dos colaboradores, lhes enviamos o trabalho, explicitando a liberdade para sugestões e críticas.

Nesse sentido, o que instituímos se aproxima da metodologia conhecida como pesquisa-ação ou pesquisa participante ${ }^{15}$, que se configura, entre outras coisas, pelo "envolvimento das pessoas em causas ou problemas sociais" e pela redução da "distância entre o pesquisador e a sociedade" (SOMMER; AMICK, 2003, p. 2). Considerando que os nossos entrevistados são pessoas que se interessam ou estão envolvidas com a cultura local, acreditamos que seria positivo criarmos mecanismos que facilitassem a comunicação entre as partes, permitindo a interferência quando desejada. Por exemplo, Romeu Antunes, um dos entrevistados, além de suas opiniões sobre a cidade, cedeu-nos algumas fotografias e corrigiu dados equivocados.

Deste modo, persistimos na possibilidade de contribuição da pesquisa para as indagações e interesses dos colaboradores, até porque lidam com esses temas cotidianamente. O próprio Romeu, em um dos nossos primeiros encontros, relatou-nos que algumas crianças e adolescentes, na produção de trabalhos escolares, já o procuraram perguntando o que era patrimônio cultural e quais os existentes em Santa Rosa, o que nem sempre era possível ser respondido com clareza devido ao pouco material disponível para a população. Nesta perspectiva, a discussão incentivada pela nossa pesquisa pode contribuir para ampliar o conhecimento e interesse do tema entre os participantes, apesar de reconhecermos que esta não é uma garantia de uma dissertação de mestrado, que como característica principal produz uma reflexão teórica.

Ao compreendermos desta maneira, são necessários alguns esclarecimentos sobre a nossa utilização dos pressupostos da pesquisa-ação/ participante. Apesar de a literatura em geral entender que esta metodologia é vista e aplicada de diferentes formas, produzindo trabalhos que muitas vezes se contrapõem dentro do próprio campo (BRANDÃO, 2001) e admitindo a sua aplicação em uma diversidade de tipos de pesquisas (WHYTE, 1989), a concepção dominante é a de que sua função é aprimorar ou modificar uma prática (TRIPP, 2005), beneficiando as classes subalternas, principalmente no modelo latino-americano

\footnotetext{
${ }^{15}$ Ao contrário de outros autores, Thiollent $(2001$, p. 83) propõe uma diferença entre pesquisa participante e pesquisa-ação. A pesquisa participante se preocuparia apenas com a valorização e participação dos colaboradores na pesquisa, desenvolvendo uma relação de confiança, enquanto a pesquisa-ação seria centrada na ação, no agir. Deste modo, a pesquisa-ação seria um tipo de pesquisa participante, mas com características particulares. Como nosso trabalho não se resume a uma proposta típica de pesquisa participante ou pesquisaação como definida pela teoria, mas apenas utiliza seus referenciais para pensar a relação pesquisador/entrevistados, essas diferenciações não se tornam determinantes em nosso projeto. Inclusive, poderíamos utilizar outra terminologia sem esvaziar o sentido do que desejamos desenvolver, como a expressão pesquisa compartilhada, citada por Brandão (2001, p. 251).
} 
desenvolvido entre as décadas de 60 e 80 do século XX, influenciado pela teologia da libertação, o marxismo e a educação popular de Paulo Freire. Assim sendo, observamos que a nossa proposta não se adéqua completamente a esta compreensão. Primeiro, porque não privilegiamos uma classe subalterna; alguns dos nossos entrevistados são pessoas reconhecidas socialmente e que podem implementar mudanças culturais na cidade. Depois, porque por mais que tenhamos o desejo de beneficiar os participantes de alguma forma com a ampliação do debate sobre o assunto, o compromisso principal é com a produção de uma discussão e análise teórica sobre o patrimônio cultural da cidade, enquanto os efeitos sociais são colocados como uma possibilidade e intenção planejada. Mesmo concordando com Demo (2001) de que teoria e prática não se dissociam, é recorrente a afirmação que "o objetivo último da pesquisa[-ação] é a transformação da realidade social e a melhora do nível de vida das pessoas que estão imersas nessa realidade" (GABARRÓN; LANDA, 2006, p. 113), enquanto a adequação à linguagem acadêmica, a publicação dos resultados em revistas especializadas e a participação em eventos são considerados secundários e dispensáveis, o que não é exatamente o nosso caso.

Apesar de ser importante a compreensão do texto pelos participantes, não acreditamos que fosse necessário colocar as discussões em uma linguagem dita popular, pois os leitores envolvidos eram universitários e profissionais qualificados, com meios para interpretar o conteúdo da dissertação. Ainda, ao sermos vinculados a um programa de pós-graduação que se enquadra naquilo que alguns pesquisadores participantes chamam de "modelo tradicional", optar por tal caminho seria romper com os compromissos estabelecidos e a proposta inicial da pesquisa.

O que estabelecemos foi a não rigidez da separação entre sujeito e "objeto", como se os entrevistados fossem apenas fontes de informação a serem analisadas posteriormente por um pesquisador autorizado. Permitimos e solicitamos que estes também opinassem, questionassem e pedissem mudanças se não concordassem com as nossas considerações sobre as representações da cidade, seus moradores e bens culturais. Portanto, a apresentação dos seus perfis, os trechos das entrevistas inclusos na dissertação e a própria analise desenvolvida só foram possíveis devido à disponibilidade dos participantes em compartilhar suas experiências, depois revisá-las e finalmente concordar com sua publicação no formato atual.

Buscamos a possibilidade de se instituir um meio de trocas e comunicação entre o conhecimento produzido por estes moradores, a partir de suas vivências na cidade, e as discussões teóricas provenientes da academia. Assim, desenvolve-se uma reflexão sobre o cotidiano, as memórias e as experiências individuais desses moradores por uma pesquisa 
universitária, ao mesmo tempo em que o uso desta perspectiva pode instigar e contribuir para responder as dúvidas dos entrevistados sobre esse tema e servir de uma fonte de informação nas decisões sobre o patrimônio cultural em Santa Rosa.

Em suma, acreditamos no que na Ciência da Informação é chamado de mediação, ou seja, a aproximação entre duas partes/ grupos/ indivíduos que estão distantes e não se comunicam, estabelecendo uma relação de diálogo, de revisão, de partilha que beneficia ambos. Porém, antes de afirmar que foi feita uma mediação cultural é importante discutir esta expressão, que se apresenta em diferentes contextos seja na Ciência da Informação como em áreas afins. Torna-se necessário esclarecer as diversas concepções existentes sobre o que é e como se faz uma mediação cultural, assim como suas possibilidades e limites. Posteriormente, já com um quadro teórico de referência, discutiremos a noção de mediação cultural que foi aplicada nesta pesquisa a partir de um diálogo com a história oral.

\section{$3.2 \mathrm{O}$ que é mediação cultural?}

No senso comum, o termo mediação sugere a existência de um conflito a ser mediado, resolvido. No judiciário, juízes e advogados exercem a função de mediar interesses de partes em oposição na tentativa de um acordo, resolução. Segundo Davallon (2007), não é este o significado de mediação encontrado na Ciência da Informação. Na Ciência da Informação (CI), o termo, geralmente adjetivado de cultural, é utilizado quando há somente "uma falta, um desvio", que pode ser compensado com a intervenção de um mediador. De maneira geral, a mediação cultural constituiria em um processo que

\footnotetext{
visa aceder um público a obras (ou saberes) e a sua ação consiste em construir uma interface entre esses dois universos estranhos um ao outro (o do público e o, digamos, do objeto cultural) com o fim precisamente de permitir uma apropriação do segundo pelo primeiro (DAVALLON, 2007, p.3-4, grifo nosso).
}

No entanto, nossa dúvida, que também parece ser do autor, é como, na prática isto é possível? Em quais situações a mediação cultural é justificável? Quem deve ser este mediador? Ele é suficiente para uma mediação? Mesmo se não exista uma resposta para todas estas indagações, o simples questionamento já é um começo para melhor entender esta noção. 
Frequentemente, a expressão mediação cultural é usada como sinônimo de mediação da informação. Em alguns casos, como em Perrotti e Pieruccini (2007), esclarece-se que toda mediação da informação também é cultural, pois envolvem produção de significados, linguagens, discursos. Entretanto, em outros trabalhos, esta relação não é explícita. Na bibliografia disponível consultada, observa-se que a utilização da expressão mediação da informação está muito próxima de mediação cultural, seja nas suas definições como nos questionamentos suscitados. Parece que a escolha de um ou de outro está intrinsecamente relacionada ao ambiente onde se realiza esta mediação. Quando o ambiente é uma biblioteca e o mediador o bibliotecário prefere-se utilizar mediação da informação. Já quando se discute a mediação de obras de museu e do patrimônio cultural é mais comum encontrarmos a preferência pela expressão mediação cultural. De modo geral, observa-se que não há uma discussão das diferenças e similaridades entre as duas utilizações, e a escolha de cada uma está mais relacionada ao ambiente onde se realizará a mediação do que suas pretensões. Deste modo, acreditamos que ainda está por ser feita uma melhor delimitação do uso de cada termo.

Almeida Júnior (2008) busca uma conceituação para mediação da informação ao perceber as diversas propostas existentes. De início, defende que a mediação da informação está presente em todas as ações do profissional da informação, e não somente naquelas diretas e intencionais, como faz o bibliotecário no serviço de referência e o monitor em uma exposição. Para ele, o objetivo de qualquer trabalho realizado pelo profissional da informação é estabelecer uma mediação, pois a define como

toda ação de interferência - realizada pelo profissional da informação -, direta ou indireta; consciente ou inconsciente; singular ou plural; individual ou coletiva; que propicia a apropriação da informação que satisfaça, plena ou parcialmente, uma necessidade informacional (ALMEIDA JÚNIOR, 2008, p. 3, grifo nosso).

Embasado por esta definição, Almeida Júnior (2008) estabelece um raciocínio sobre o objeto da CI. Diz que é comumente aceito que o objeto do campo é a informação registrada, porém, na sua visão, esta premissa deve ser revista. Para o autor, em primeiro lugar a informação registrada não é permanente, e para exemplificar esta afirmação utiliza o exemplo das informações na Internet, e em segundo, uma informação só existe na medida em que o usuário a reconhece como informação. 
(...) a informação é efêmera e se concretiza apenas no momento em que se dá a relação do usuário com o suporte que torna possível a existência dela, informação. Assim, ela não existe a priori, ela não existe antes da relação usuário/ suporte, o que redunda em defendermos que o profissional da informação trabalha com uma informação latente, uma "quase-informação". Preferimos chamá-la de "protoinformação" uma vez que ela não é, ainda, uma informação (ALMEIDA JÚNIOR, 2008, p. 10).

Deste modo, defende que o real objeto da CI não é a informação, mas a sua mediação, pois o objetivo de qualquer trabalho realizado pelo profissional da informação seria permitir que o usuário a utilize e aproprie. Tudo é realizado pensando na mediação e não na informação em si, como algo isolado, pré-estabelecido, até porque ela "não existe" sem o usuário.

Na Ciência da Informação, uma das definições mais utilizadas de mediação é a da ação de servir de intermediário ou de ser o que serve de intermediário entre dois níveis diferentes, que por fim permitirá um estado mais satisfatório (DAVALLON, 2007, p. 6). Portanto, há uma ideia que este mediador possui uma legitimidade, autoridade, algo que pode ser transmitido ou ensinado para um outro que não possui seu conhecimento. É o bibliotecário que precisa auxiliar o usuário, o profissional especializado que explica uma obra para o visitante do museu, o arquivista que orienta o pesquisador, etc.

A nosso ver, entender a mediação como transmissão de informação de um polo que sabe para o outro que deve ser ensinado apresenta o risco de colocar a mediação como um processo unidirecional e não dialógico, não considerando o destinatário da mediação tão protagonista quanto o mediador. Compreender a mediação como uma relação entre dois níveis diferentes não significa que um nível seja superior ao outro, mas que apenas não são iguais. Assim sendo, acreditamos e enfatizamos ser mais promissor considerar que quem exerce o papel do mediador, em certa medida, também é destinatário da mediação e vice-versa.

Um exemplo de mediação apresentado por Davallon (2007) é a mediação midiática. Ao contrário da mediação face a face, esta mediação só existe por intermédio de um meio. Neste caso, o mediador pode ser o jornalista, que em um debate, discussão, exerce o papel de intermediário com o público. Desta forma, além de permitir a comunicação, o jornalista processa a informação para transmiti-la ao público, que mais facilmente a assimila e apropria.

No entanto, mesmo aplicada em diferentes contextos, Davallon (2007, p. 9-10) enumera algumas características que aparecem na maioria das definições de mediação. De modo geral, “esta ação produz sempre, em maior ou menor grau, um 'efeito' sobre o 
destinatário da comunicação: ele vai aceder, aprender, passar, etc."; a ação "tem sempre um impacto sobre o ambiente (mais frequentemente o ambiente social) no qual ela se situa a mediação", e a comunicação pressupõe a interação entre dois sujeitos, permitindo, pela comunicação, a transferência de informação.

Uma interessante abordagem dentro da CI encontra-se em Pieruccini (2007) quando analisa a mediação cultural em uma biblioteca escolar. Ao contrário de inúmeros trabalhos que priorizam apenas a relação do bibliotecário com o usuário da biblioteca, a autora aponta a necessidade de considerar todo o ambiente na mediação, que na sua expressão, permite uma “ordem informacional dialógica". Deste modo, a mediação não se realiza apenas na interação entre humanos, mas também com dispositivos.

Sua concepção de dispositivo é de "um local social de interação e de cooperação", seja em sua dimensão material como simbólica. O que a autora sublinha é que além dos indivíduos, os objetos, artefatos, ferramentas e tudo mais que não é humano também possui significação, o que os configuram como instrumentos de mediação. Para ela, os dispositivos ordenam, organizam, dizem, narram, interferindo na apropriação da informação. Por isto, além da relação entre as pessoas, Pieruccini destaca o papel da arquitetura, da organização dos espaços, dos materiais utilizados, a ordem dos livros, as classificações utilizadas e tudo mais que influencia neste processo de comunicação.

\begin{abstract}
Desta forma, a ordem discursiva dos dispositivos constitui instância de mediação, que atua nas relações entre o sujeito e o universo simbólico, razão pela qual sua configuração deve ser entendida como mecanismo portador de significados que pode tanto atuar de modo definitivo nos processos de apropriação de informações ou apenas como dispositivos voltados à oferta/ acesso a informações, contribuindo, implicitamente, para formar recepetores-consumidores-culturais (PIERUCCINI, 2007).
\end{abstract}

De qualquer modo, a autora não deixa de mencionar o papel dos mediadores humanos, que, no ambiente de seu estudo, são os professores e profissionais da informação, principalmente o bibliotecário. Para estes, também denominados infoeducadores, é necessário o domínio de dois campos do saber, a educação e a informação. Novamente, retornamos ao questionamento inicial das possibilidades de mediação cultural entre dois sujeitos. No entanto, na pesquisa de Pieruccini, esta relação só pode ser realizada se existir uma ordem informacional dialógica, ou seja, o ambiente também se configurar como um sistema dirigido de significação. 
A relevância da pesquisa de Pieruccini, em nossa opinião, consiste em situar-se em um ambiente tradicional, a biblioteca escolar, em que na maioria das vezes a mediação é tratada como uma relação de autoridade, entre alguém que sabe e outro que deve aprender, mas que neste caso, foi abordada em uma perspectiva ampla, em que o ambiente também é mediador. É claro que isto não exclui as indagações sobre a figura do mediador, porém demonstra que esta interação é mais complexa do que geralmente é apresentada.

Junto com Perrotti (2007), Pieruccini ainda desenvolve a noção de apropriação, que é o objetivo final da mediação. Para ambos, a apropriação consiste em tornar próprio alguma coisa, ou seja, adaptá-la, torná-la sua, uma expressão de si (PERROTTI; PIEURUCCINI, 2007, p. 73). Isto significa diferenciar a noção de apropriação de assimilação, pois exige não somente um entendimento de algo, mas sua transformação, a produção de significados.

Quando o indivíduo se apropria da informação, ele deixa de ser mero usuário ou consumidor, mas torna-se um "protagonista cultural", "produtor e criador de significados e sentidos", com domínio sobre processos simbólicos e "participação ativa e afirmativa na vida cultural" ${ }^{16}$ (PERROTI; PIERUCCINI, 2007, p. 57). Portanto, a mediação cultural não se limita apenas à transferência de informação, mas cria condições para que os indivíduos possam discernir, refletir, questionar e transformar todo o universo cultural que os rodeia. Ao invés de pensar o mediador apenas como um intermediário, uma "ponte" entre a informação, a cultura e o indivíduo, parece ser mais promissor pensar o mediador como alguém que oferece condições para que os sujeitos desenvolvam seus próprios fins.

Nesta perspectiva mais ampla, o mediador não precisa, necessariamente, estar em contato direto com o destinatário da mediação, mas pode auxiliá-lo, por exemplo, oferecendo um serviço que facilite a apropriação cultural. No caso anterior da biblioteca escolar estudada por Pieruccini, aqueles que idealizaram toda a organização dos dispositivos também podem ser considerados mediadores, mesmo se quando os alunos utilizam a biblioteca eles não estejam presentes.

Com este quadro de reflexões, observa-se como a noção de mediação cultural está longe de uma definição unívoca e simples. Isto não é necessariamente ruim, mas a princípio, apenas demonstra a abrangência de um termo, utilizado em diferentes áreas do conhecimento

\footnotetext{
${ }^{16}$ Tais concepções provêm de uma área de estudos desenvolvidas pelos próprios pesquisadores, que a denominaram "Infoeducação", que como o próprio nome diz, é um campo de intersecção entre a Educação e a Ciência da Informação. Segundo os autores, a Infoeducação é uma "área de estudo, situada nos desvãos das Ciências da Informação e da Educação, voltada à compreensão das conexões existentes entre apropriação simbólica e dispositivos culturais, como condição à sistematização de referências teóricas e metodológicas necessárias ao desenvolvimento dinâmico e articulado de aprendizagens e de dispositivos informacionais, compatíveis com demandas crescentes de protagonismo cultural, bem como de produção científica, constituída sob novas óticas, nas chamadas Sociedades do Conhecimento" (PERROTTI; PIERUCCINI, 2007, p. 92).
} 
com diferentes finalidades, como na Filosofia, Educação, Sociologia, até chegar à Ciência da Informação.

Almeida (2007), em um trabalho que aponta para as relações existentes entre a concepção de mediação cultural utilizada na CI com a Sociologia, principalmente os estudos culturais ingleses, sintetiza esta amplitude da expressão:

\begin{abstract}
A ideia de mediação acaba por cobrir coisas tão diferentes entre si, que vão das velhas concepções de "atendimento ao usuário" à atividade de um agente cultural em uma dada instituição - museu, biblioteca, arquivo, centro cultural -, à construção de produtos destinados a introduzir o público num determinado universo de informação e vivências (arte, educação, ecologia, por exemplo), à elaboração de políticas de capacitação ou acesso às tecnologias de informação e comunicação, etc. Desse modo, uma definição consensual de mediação parece impraticável: sempre contextualizada, torna-se um conceito plástico que estende suas fronteiras para dar conta de realidades muito diferentes entre si (ALMEIDA, 2007).
\end{abstract}

Ao considerarmos estas possibilidades, a mediação pode ser pensada em diferentes contextos e pesquisas, mesmo quando ela não está explícita ou é o tema central. Uma interessante reflexão é a de Latour (2000) quando discute o papel de laboratórios, bibliotecas e coleções ao transformar o mundo em inscrições. Para ele, estes "centros de cálculo" servem, nas suas palavras, "de intérprete, de intermediário, de encruzilhada, de distribuidor, de central telefônica, de dispatcher, a fim de regular as relações múltiplas entre o trabalho de redução e o trabalho de amplificação" (LATOUR, 2000, p. 26).

Quadros, objetos selecionados, animais empalhados, textos, fotografias realizam uma operação de seleção, extração e redução do mundo ao sintetizar informações de um lugar. Ao mesmo tempo, quando estas inscrições estão expostas em um museu, biblioteca, arquivo, ao alcance do público ou pesquisador, ou seja, submetidas ao movimento da amplificação, é possível a relatividade, a comparação, uma coerência ótica entre informações que estariam dispersas se não tivessem passado por estas operações. O que é isto? Uma mediação que permite uma melhor compreensão do mundo. Os mediadores: pintores, fotógrafos, escritores, bibliotecários, cartógrafos e todos os outros profissionais que possibilitam esta relação entre dois lugares, uma "periferia", de onde se extrai estes registros, e um “centro", onde é possível reuni-los com propósitos determinados (LATOUR, 2000).

Em se tratando de mediação cultural, não podemos deixar de citar as colocações de Teixeira Coelho, pois foi um dos primeiros autores a pensar a mediação e ação cultural no âmbito da Ciência da Informação no Brasil. Primeiro, Teixeira Coelho trabalha o conceito de 
ação cultural - diferente de fabricação e animação cultural - explicando que sua função é fornecer todos os meios para que as pessoas inventem seus próprios fins no universo cultural (COELHO NETTO, 1986).

De forma sucinta, diz que ação cultural é uma intervenção sociocultural não continuada (COELHO NETTO, 1986, p. 18), e, com base em seus trabalhos, concluímos que a mediação cultural é uma forma de ação cultural. Na sua definição, mediação cultural é:

\begin{abstract}
Processos de diferente natureza cuja meta é promover a aproximação entre indivíduos ou coletividades e obras de cultura e arte. Esta aproximação é feita com o objetivo de facilitar a compreensão da obra, seu reconhecimento sensível e intelectual - com o que se desenvolvem apreciadores ou espectadores, na busca de formação de públicos para a cultura ou de iniciar esses indivíduos e coletividades na prática efetiva de uma determinada atividade cultural (COELHO NETTO, 1997, p. 248).
\end{abstract}

Para Almeida (2007), o pensamento de Teixeira Coelho permite um diálogo com o movimento da década de 1980, verificável na produção de pesquisadores brasileiros e latinos americanos, de ver a cultura como processo de construção da hegemonia, como apresentado por Gramsci. Como exemplo, o autor (2007) cita o XI Congresso Brasileiro de Biblioteconomia e Documentação ocorrido em 1982 em João Pessoa, Paraíba, quando Paulo Freire fez uma apresentação relacionando algumas ideias gramscianas. Desta forma, a discussão de Almeida (2007) mostra um caminho para pensar a contribuição dos Cultural Studies na formulação de uma noção de mediação cultural na CI.

Ainda em sua conceituação, Teixeira Coelho apresenta outra interface da mediação, a tecnologia, principalmente os meios de comunicação. Segundo Teixeira Coelho (1997, p. 248), “diz-se ainda que os meios de comunicação, sendo por um lado eles mesmos produtos culturais acabados que se apresentam como fins em si, operam uma mediação entre os diversos segmentos e modos culturais da sociedade”. Davallon (2007, p. 9) também reconhece esta utilização do termo e sublinha que a mediação não é apenas técnica, mas social, pois ao mesmo tempo em que envolve a "tecnicização do processo de comunicação" é "intervenção da dimensão subjetiva nas práticas de comunicação". No entanto, se há uma discussão desta perspectiva na Ciência da Informação, foi na Comunicação que ela mais se desenvolveu.

Martin-Barbero (1997), ao considerar os meios de comunicação (desde o folhetim à televisão) como mediadores, destaca o papel destes meios em um processo de transformação cultural. Os meios de comunicação produzem uma circulação de significados que é uma 
mediação da cultura, um lugar de relações entre "o Estado e as massas, entre o rural e o urbano, entre as tradições e a modernidade” (MARTIN-BARBERO, 1997, p. 249).

Apesar de não dialogar com este autor em suas referências, o mesmo parece ser a visão de Silverstone (2002). Para ele, devemos pensar a mídia como um processo de mediação que possibilita a criação e circulação de significados, uma interpretação do mundo. Silverstone (2002) utiliza a ideia de tradução para explicar a mediação como um processo incompleto e insatisfatório, mas sempre transformativo. Ao participarmos deste processo todos nós somos mediadores, personagens ativos nesta produção de significados que nunca se fecha, mas sempre está em constante movimento.

Portanto, ao pensarmos a influência crescente destas tecnologias na mediação é necessário irmos além da relação entre emissor e receptor, mesmo se ambos são ativos e troquem de posição constantemente, e refletir as mudanças sociais, econômicas e políticas que permitiram ou até mesmo solicitaram novas formas de disponibilizar, tornar acessível e utilizar informações. Somente desta forma teremos uma melhor noção do papel das tecnologias, especialmente os meios de comunicação, na mediação cultural.

Mais complementares do que divergentes, cada abordagem mostra uma maneira de pensar a mediação, a figura do mediador, o ambiente no qual ela ocorre, os dispositivos, com destaque para as tecnologias. Seguindo nosso raciocínio, um ponto que ainda merece ser explorado é como este destinatário, receptor, usuário, que participa da mediação, é visto pelo chamado mediador e vice-versa, e como a relação entre ambos possibilita a eficácia da mediação. Como vimos, autores que conseguiram problematizar a mediação cultural recorreram a estudos da Educação, Comunicação e Sociologia, que pelas discussões existentes mostraram intersecções que podem ser úteis para a Ciência da Informação.

\subsection{Um Diálogo entre a Ciência da Informação e a História Oral}

Especificamente em nossa pesquisa, visamos discutir com moradores de Santa Rosa de Viterbo a atribuição de predicados a elementos culturais da cidade, permitindo a sua valorização como patrimônios pela população. Para isto, realizamos encontros em que foram abordadas as suas percepções sobre os eventos, os lugares históricos, de lazer, de trabalho, existentes neste espaço urbano. Um dos intuitos destas interações foi permitir que os participantes também se beneficiassem dos nossos questionamentos, a ponto de refletir sobre aspectos da cidade que geralmente são ignorados sem o início de um processo que objetive esse fim. Estimular uma reflexão sobre a cidade permite tornar explícita para o participante 
suas percepções sobre o lugar, as suas representações e o que ele acredita ser as dos outros, que de uma forma mais ampla também o capacita para a ação social, se ele desejar, no convívio com os familiares, amigos, conhecidos.

Procuramos discutir maneiras pelas quais o habitante também pudesse ser um participante ativo e colaborador da pesquisa e as condições para que ele também se beneficiasse destas interações. Para tanto, encontramos referências no campo de conhecimento conhecido como história oral ${ }^{17}$, que relacionadas com o que levantamos sobre mediação cultural, contribuíram para o desenvolvimento de nossa relação com os entrevistados.

Esclarecemos que o nosso objetivo não foi realizar um trabalho de história oral, mas, a partir de métodos elaborados por este campo do conhecimento, desenvolver uma mediação com os moradores da cidade com o intuito de estimular o protagonismo cultural a partir da apropriação simbólica dos lugares e seus atores, algo que tem se revelado importante para a Ciência da Informação, como demonstram os estudos em Infoeducação.

$\mathrm{O}$ ponto de encontro entre estas duas áreas em nosso projeto foi a realização de entrevistas, muito utilizadas e discutidas em história oral, para estabelecer uma mediação cultural, tema de estudos na CI. Acreditamos neste diálogo, pois enquanto a história oral se preocupa com a produção de registros por meio de entrevistas e o acesso à informação (no nosso caso, as transcrições e outros documentos produzidos foram enviados aos participantes), a CI, especialmente a Infoeducação e as pesquisas em ação e mediação cultural, priorizam a apropriação da informação, que em nossa proposta visa uma maior reflexão, discernimento e conhecimento dos patrimônios culturais de Santa Rosa de Viterbo.

Ressaltamos ainda a relevância da pesquisa ao verificar que a cidade não possui um arquivo público com profissionais qualificados que poderiam permitir o acesso e utilização de documentação sobre o local. Deste modo, a população não dispõe de instrumentos e registros para pesquisar, conhecer, discutir e questionar a história e a cultura em Santa Rosa, a não ser que se disponha a um exaustivo trabalho geralmente realizado por profissionais

\footnotetext{
${ }^{17}$ De modo amplo, podemos definir a história oral como a história que dá grande ênfase à consulta de fontes orais, essencialmente entrevistas transcritas, que junto com fontes mais tradicionais, como correspondências, leis, jornais, etc., auxiliarão na análise de um tema/ problema. A peculiaridade de utilizar fontes orais em uma pesquisa é que geralmente elas não existem a priori, mas devem ser produzidas durante o projeto, seja pelo próprio pesquisador ou, em trabalhos de grande abrangência, por uma equipe dirigida por ele. Assim, o pesquisador deve ir a campo, se relacionar com a comunidade que deseja compreender, estabelecer um contato que permita a realização de entrevistas e os demais processos de produção destas transcrições a serem utilizadas.
} 
especializados, como ir à Câmara Municipal, Prefeitura e outras instituições na tentativa de encontrar sozinho algo relevante em arquivos dispersos ${ }^{18}$.

Conscientes dessas limitações, apresentamos os princípios que consideramos para a realização das entrevistas e que permitiram a produção dos capítulos seguintes, que como referencial teórico utiliza tanto discussões próprias da CI, como de disciplinas, que na nossa compreensão, podem colaborar para o seu desenvolvimento nas Ciências Humanas.

Segundo Davallon (2007, p. 10), um dos pressupostos para a realização da mediação é a valorização do destinatário/ entrevistado como sujeito, respeitado, e não instrumentalizado. A mediação só é possível quando o mediador acredita na capacidade do destinatário em entender, aprender, passar, estabelecendo uma relação dialógica e não unidirecional. Desta forma, ao perceber seu papel na pesquisa, o entrevistado deixa de ser apenas um meio para a concretização de objetivos de terceiros, mas entende que também pode se beneficiar dela, tirar algum proveito.

Thompson (2002, p. 33), um reconhecido historiador oral norte-americano, apresenta uma destas possibilidades de valorização dos indivíduos e intervenção social. Em projetos que preveem o encontro de pessoas com características em comum, como provenientes de uma mesma região, de uma mesma classe profissional, entre outros, existe uma grande oportunidade de indivíduos com interesses similares se conhecerem, fazerem amizades e até mesmo se organizarem para conseguir realizar seus planos. O interessante da história oral é que estas possibilidades não são tratadas como um benefício "extra" da pesquisa, como algo que talvez possa acontecer, mas são inseridas no projeto, primeiro como fonte de estudo, depois como retorno para a sociedade que colaborou na realização da pesquisa. $\mathrm{O}$ planejamento não se limita à obtenção de informações necessárias para o projeto, mas também no impacto social que ele possibilita. Assim sendo, no ponto de vista adotado, estabelecer uma relação dialógica em que ambas as partes pudessem se beneficiar da problematização de elementos culturais foi uma maneira de estabelecer uma mediação.

No entanto, a simples intenção de que a mediação ocorra muitas vezes não é suficiente. Novamente, a história oral desenvolveu discussões sobre o ambiente e as características do entrevistador/ entrevistado para que uma interação se estabeleça. Primeiro, deve-se pensar sobre quem entrevista quem. Em uma pesquisa sobre violência contra as mulheres, uma mulher pode adquirir mais confiança de uma entrevistada do que um homem; para discutir preconceitos raciais, um entrevistador negro pode ser mais apropriado para

\footnotetext{
${ }^{18}$ A instalação de um Centro de Memória nas dependências da Biblioteca Municipal com o objetivo de organizar, preservar e divulgar a documentação existente pode mudar esse quadro nos próximos anos.
} 
entrevistar um negro do que um branco, etc. Tudo isto parece simples com exemplos extremos, mas na maioria das pesquisas, em que antagonismos não são tão explícitos, esquecemos de questionar esta relação. Entretanto, como mostra Thompson $(2002,159)$, pesquisas já demonstraram que as mesmas pessoas para as mesmas perguntas respondem de maneiras diferentes dependendo das características do entrevistador.

Portelli (1998; 2004), um dos principais historiadores orais italianos, ao realizar pesquisas com pessoas envolvidas direta ou indiretamente com a Segunda Guerra Mundial, nos mostra como a visão construída sobre o entrevistador pode influenciar no estabelecimento de um diálogo. Encontramos em seus trabalhos a preocupação dos entrevistados em saber quem são os pesquisadores para determinar o que dirão, e, neste caso, compartilhar uma posição política e ideológica foi essencial para que algumas entrevistas obtivessem uma maior participação.

Especificamente em nossa pesquisa, encontramos maior resistência de participação de moradores quanto mais próximos eles estavam da administração municipal. Possuir um cargo público ou ser responsável por projetos fez com que alguns entrevistados ficassem receosos da exposição que a pesquisa poderia conseguir, o que reforça a necessidade de negociação para estabelecer uma relação de confiança.

Retornando à Ciência da Informação, estes problemas podem contribuir ao discutir, por exemplo, quem pode ser e as necessidades de um mediador em um museu do holocausto, como o existente em Washington, nos Estados Unidos, ou em um museu da cultura africana, como o Museu Afro Brasil, em São Paulo. Não queremos dizer que um profissional proveniente destes grupos seja o melhor para trabalhar nestes locais, mas que é importante estudos sobre como estes profissionais são vistos pelos públicos, usuários, para compreender as possibilidades e níveis de interação. Não existe um modelo a ser seguido. Cada perfil apresenta vantagens e desvantagens na mediação. No nosso caso, no qual pretendemos discutir as percepções sociais dos habitantes sobre determinada cidade, se o entrevistador também é um morador, uma das vantagens é um maior conhecimento sobre o lugar e seus moradores, o que auxilia na identificação dos problemas a serem discutidos; por outro lado, o fato de compartilhar um ambiente comum, pode inibir o entrevistado a emitir opiniões polêmicas, em que o pesquisador pode ser um dos interessados, exatamente por participar do dia-a-dia da cidade. Outras vantagens e desvantagens ocorreriam se o entrevistador fosse alguém de um lugar distante. O importante, e o que sublinhamos, é refletir sobre o perfil, as características, as expectativas e representações do entrevistado em relação ao entrevistador e vice-versa, ou mais amplamente, entre o mediador e o destinatário da mediação. 
Deve-se salientar que não é necessariamente verdade que um entrevistador do mesmo sexo, classe ou raça obtenha informações mais precisas. Se a relação social numa entrevista é, desde o início, ou passa a ser um vínculo social, aumenta o perigo na direção da conformidade social das respostas. Como também maior intimidade nem sempre acarreta menor inibição. É notável, por exemplo, como muitas pessoas, quando abordadas anonimamente na rua por pesquisadores de opinião e perguntadas a respeito de sexo, se dispõem a responder com uma franqueza que não é comum na entrevista mais reservada feita em casa (THOMPSON, 2002, p. 160-161).

Com estas premissas, um dos aspectos a ser considerado na mediação cultural é como as características, reais e imaginadas, do mediador e do destinatário da mediação influenciam nessa interação, como aproveitar e quais as vantagens de cada perfil, e como lidar com as desvantagens de uma compreensão do "outro" que dificulta essa comunicação.

Outro ponto a ser pensado é onde esta mediação ocorre. Na Ciência da Informação encontramos discussões sobre mediações que acontecem em museus, bibliotecas, arquivos, centros culturais, sem que uma abordagem seja feita sobre como o ambiente da mediação a influencia. Até o momento, trabalhos deste tipo ainda aparecem no âmbito da exceção, como os já citados em Perrotti e Pieruccini (2007).

Apesar da necessidade de um ambiente que permita alguma privacidade e boas condições de gravação, a definição dos locais onde ocorrerão as entrevistas em história oral é geralmente decidido pelos entrevistados, pois acredita-se que ele se sentirá mais confortável em conversar em um local que já conhece e se sente bem (MEIHY, HOLANDA, 2007, p. 16). Caso o pesquisador pense que o local não é apropriado por algum motivo, estabelece-se uma negociação para que o local seja o melhor possível para ambos. No nosso caso, entrevistas ocorreram tanto nas casas quanto no trabalho dos participantes.

Isto acontece, pois em história oral o ambiente onde acontecem essas interações é determinante para o tipo de fonte a ser produzida e também para o envolvimento dos sujeitos nas discussões. Thompson (2002, p. 163) explica como cada lugar estimula um comportamento a partir das convenções sociais: em um bar, o clima é mais descontraído, as pessoas se tornam mais desinibidas em falar o que pensam, mas ao mesmo tempo, o risco de atrevimentos, de conceber a entrevista como uma brincadeira é maior; no local de trabalho, o tom tende a ser mais formal; na sua casa, é provável que o entrevistado se sinta mais confortável, por outro lado, os demais moradores, exatamente por estarem em sua residência, muitas vezes não se incomodam em interromper a entrevista. Estas considerações são ainda 
relevantes, pois, para a história, conhecer as condições de produção de uma fonte é essencial para a sua crítica. No entanto, acreditamos que a Ciência da Informação também pode se beneficiar desta preocupação e questionar alguns dos seus ambientes tradicionais onde projetos de mediação usualmente são aplicados.

Frequentemente, quando se fala em mediação cultural na Ciência da Informação o ambiente é a biblioteca, o museu ou o arquivo. Tal é a ocorrência destes ambientes que eles acabam por se naturalizarem, como se não influenciassem na mediação. Apesar de abranger uma discussão mais ampla, que inclui a família, a educação e a classe social, Bourdieu e Darbel (2003) nos mostra como a visão construída sobre estes lugares influencia o nosso comportamento e disponibilidade para com o que estas instituições oferecem. Portanto, compreender o imaginário social sobre o museu, a biblioteca e o arquivo é uma vantagem do profissional mediador para lidar com diferentes sujeitos/ públicos, pois as chances da eficácia da mediação aumentam se conhecermos minimamente as possibilidades e riscos das interações em cada ambiente.

Nossa proposta de pesquisa constituiu em encontros individuais com habitantes selecionados da cidade em locais determinados por estes. O intuito foi a formação de um pequeno grupo que discutisse aspectos culturais de Santa Rosa, principalmente no que se refere aos seus patrimônios. A definição de uma quantidade não muito grande de pessoas deveu-se aos objetivos qualitativos da pesquisa, que não planejou identificar amostragens numericamente significativas de opiniões. Mais importante que a incidência de uma opinião na sociedade foi a profundidade das discussões com os habitantes escolhidos.

Uma noção muito utilizada em história oral é a de singularidade. Interagir com pessoas dispostas a discutir, que tem algo a contar é considerado mais representativo do que apenas conseguir um número elevado de pessoas para participar. Deste modo, ao contrário de procurar um quadro de experiências comuns, pretendeu-se entender "um campo de possibilidades compartilhadas, reais ou imaginárias" (PORTELLI, 1996).

Estas possibilidades se apresentam pelas formas como os indivíduos interpretam o passado e o presente por meio de suas experiências subjetivas (CRUIKSHANK, 1998, p. 156). Através da memória, eles podem repensar suas representações ao longo do tempo, como compreendem o espaço urbano e quais são suas expectativas. No entanto, estas reflexões não são espontâneas, porque na maioria das vezes não termos consciência das imagens sociais que compartilhamos e como elas foram construídas. É exatamente aí que surge a necessidade da mediação. Estimular uma reflexão não garante que as pessoas compreenderão determinadas representações, mas permite ao menos que elas percebam sua participação no imaginário 
social, se perguntem sobre o que pensam, questionem se as outras pessoas também pensam desta forma, enfim, ficam mais próximos de um "protagonismo cultural" na cidade, recorrendo à terminologia utilizada por Perrotti e Pieruccini (2007).

\begin{abstract}
Por memória podemos compreender reminiscências, através das quais nos encontramos com o passado, repetição de atitudes e sentimentos dos quais raramente nos damos conta, construção e reconstrução de nossas identidades ao longo de nossas vidas, e até mesmo o inexplicável saber. Estes são, no entanto, aspectos da memória que só podem coexistir e serem criticamente analisados numa orientação que considere que eles não só se transformam ao longo do tempo, como também transformam o presente à medida que reinterpretam o passado (SANTOS, 2002, p. 146).
\end{abstract}

Como nosso projeto previu encontros e entrevistas, incentivamos uma relação permanente com os moradores entrevistados para que efetivamente fossem inseridos nas discussões levantadas. Para isto, o contato foi dividido em etapas que se complementaram. Primeiro, explicamos a finalidade da pesquisa para cada habitante selecionado. Posteriormente, realizamos uma entrevista gravada que discutia a cultura na cidade. Quando necessário, outras contatos foram realizados para uma maior compreensão dos assuntos abordados. Como é comum que os participantes exerçam atividades como estudo, trabalho, entre outros, limitando sua disponibilidade de tempo para a pesquisa, e o fato de algumas questões/ dúvidas que surgiram durante esse período serem de fácil elucidação, também utilizamos telefonemas, e-mails, mensagens de texto, etc., para garantir o contato e participação dos entrevistados, até porque, como defende Pierre Levy (1999), não podemos ignorar a diversidade dos meios de comunicação e interação do mundo contemporâneo.

Depois de cada entrevista, a transcrevemos corrigindo pequenos erros de português, suprimindo trechos repetitivos, algumas interjeições, com o intuito de tornar o texto mais legível. A crítica mais comum a este procedimento é que não se está reproduzindo a entrevista como ela aconteceu, mas criando uma falsificação. A nosso ver, mesmo se transcrevêssemos tudo o que foi dito, o leitor ainda não seria capaz de recuperar toda a integridade do momento da entrevista, pois é impossível reviver uma situação localizada em um determinado espaço e período de tempo. Com diz Tourtier-Bonazzi (1998, p. 239), “toda transcrição, mesmo bem feita, é uma interpretação, uma recriação, pois nenhum sistema de escrita é capaz de reproduzir o discurso com absoluta fidelidade; de certa maneira, é uma traição à palavra". 
Assim sendo, como o pesquisador garante, mesmo com algumas mudanças, que a transcrição respeitou a opinião do entrevistado? O texto produzido foi enviado a ele para que o lesse, inserisse e retirasse trechos que preferiria não ver divulgado, reconhecendo sua autenticidade. Quando as intervenções feitas pelo entrevistado modificaram as ideias expressas no momento da entrevista, coube uma negociação para encontrar um ponto comum entre o que foi dito nas entrevistas e o que ele permitiu que fosse publicado. Deste modo, garantiu-se a legitimidade da fonte.

Para Meihy e Holanda (2007, p. 120), esta etapa da história oral constitui uma relação de colaboração e cooperação entre as partes. Para Thompson (2002, 297), ela apresenta benefícios e inconvenientes. Por um lado, facilita encontrar erros nas transcrições, além de incentivar o envio de novas informações. De outro, muitas vezes o entrevistado deseja reformular toda a transcrição, produzindo um outro texto, o que não deve ser permitido pelo entrevistador.

Enquanto para a história este processo garante a autenticidade e legitimidade da fonte, a Ciência da Informação pode enxergar uma possibilidade de mediação. Ao retornar ao entrevistado um texto com suas opiniões e pedir que ele o avalie, repense, corrija, institui-se uma forma de estimulá-lo a refletir sobre suas próprias ideias. Ele se coloca no lugar do outro, do ouvinte, para analisar a sua própria história. Assim, o participante torna-se um personagem ativo desta discussão, pois se envolve na produção de um produto sobre suas representações em relação à cidade.

Além do mais, quando o habitante se mostra interessado, outros textos produzidos a partir de suas experiências lhe são enviados, permitindo que durante todo o trabalho reveja seus posicionamentos sobre a cidade, sua relação com os dos outros, e discuta estas análises com sua rede social. Temos consciência que esta mediação só obtém sucesso quando o habitante está disposto a participar, no entanto, estes procedimentos possibilitam o início de um processo com esta finalidade de interação. Como demonstraram Rosenzweig e Thelen (1998), é comum em projetos que envolvem entrevistas a recusa ou a participação apenas parcial de alguns contatados. Porém, o contrário também ocorre, e para outras pessoas participar deste tipo de pesquisa é uma oportunidade, senão a única, de publicar suas opiniões e expressar o que pensam sobre determinado assunto.

Um dos objetivos finais foi refletir e compreender como os elementos culturais da cidade, principalmente os seus patrimônios, são percebidos e interpretados pela população. Este conjunto de possibilidades é capaz de mostrar em que medida o imaginário social é um dispositivo de controle e conflitos sociais na vida coletiva, como afirmou Baczko (1985, p. 
309-310). Por último, o habitante, mais consciente do lugar que ocupa e do tempo em que vive, é estimulado a ser um cidadão mais participativo, interessado pelo papel que a cidade ocupa em sua vida.

\footnotetext{
A cidade é objeto da produção de imagens e discursos que se colocam no lugar da materialidade e do social e os representam. Assim, a cidade é um fenômeno que se revela pela percepção de emoções e sentimentos dados pelo viver urbano e também pela expressão de utopias, de esperanças, de desejos e medos, individuais e coletivos, que esse habitar em proximidade propicia (PESAVENTO, 2007, p.14).
}

Por isso, acreditamos nos benefícios de dialogar com outros campos do conhecimento. As perspectivas da história oral nos mostram como áreas das Ciências Humanas, com a Sociologia, Antropologia, Psicologia, entre outras, podem contribuir para um estudo sobre a noção de mediação e, principalmente neste caso, como fazer uma mediação. Devemos ter consciência de que estas disciplinas têm um longo histórico de pesquisas de campo, métodos de comunicação com grupos sociais que permitem a Ciência da Informação utilizá-los na interação com os seus públicos, seja a nível individual como coletivo.

\subsection{História}

Até agora, discutimos como a memória possibilita ordenar o passado e questioná-lo reflexivamente. Porém, outro estágio dos projetos baseados em lembranças pessoais deve ser analisado: a produção de um texto que apresenta as conclusões sobre os diversos relatos colhidos.

Neste momento, cabe ao pesquisador colocar em evidência as contradições e relações entre os testemunhos, indo além das visões parciais de cada entrevistado. Para tanto, ele institui um diálogo entre as diferentes perspectivas encontradas para compreender e discutir a representatividade das rememorações. A partir disto, nossa atenção recai sobre como é produzida essa narrativa e como ela é recebida pelo entrevistado/ leitor.

A historiografia já contribuiu com importantes discussões sobre a escrita da história, apresentando tópicos que devem ser considerados quando desejamos entender as características que determinam a forma e a recepção desse tipo de pesquisa. Certeau (2008), por exemplo, problematiza a história ao situá-la entre dois termos aparentemente paradoxos, o real e o discurso, questionando o seu fazer entre a busca pela verdade e o reconhecimento da 
interpretação/ ficção. Ao contrário, Ginzburg (2002a) defende que retórica e prova não são antagônicas, mas que as provas constituem o núcleo fundamental da retórica, e as fontes, inclusive as orais, não são nem evidentes nem impenetráveis, exigindo uma análise que situe o que foi transmitido em seu contexto e intencionalidade.

Deste modo, seu posicionamento se contrapõe a Veyne (2008) quando aborda a natureza lacunar da história. Para este último, o conhecimento não trata daquilo que foi, ocorreu, mas do que está disponível, em sentido restrito, nas fontes existentes. Assim, quando propõe preencher as lacunas, o pesquisador apenas suporia os acontecimentos ocorridos e "o número de páginas concedidas pelo autor aos diferentes momentos e aos diversos aspectos do passado é uma média entre a importância que estes aspectos têm a seus olhos e a abundância da documentação" (VEYNE, 2008, p. 27).

O que Veyne nega é o percurso apresentado por Ginzburg para a análise das fontes, como se não fosse possível um critério rigoroso, mas somente uma submissão à disponibilidade de documentos sobre o assunto pesquisado. No entanto, Ginzburg visualiza o documento como monumento, como faz Le Goff (2003), desconstruindo-o, contextualizandoo e analisando suas condições de produção.

Nesta perspectiva, documentos que foram produzidos pela e para a classe dominante podem explicar a cultura popular; uma crítica a determinada pessoa pode revelar suas qualidades, e assim por diante, desde que se faça uma leitura não positivista das fontes. Como diz Ginzburg (2009, p. 16), “o fato de uma fonte não ser 'objetiva’ (mas nem mesmo um inventário é 'objetivo') não significa que seja inutilizável. Uma crônica hostil pode fornecer testemunhos preciosos sobre o comportamento de uma comunidade camponesa em revolta".

Ginzburg reconhece que o pesquisador lida todo o tempo com o erro, mas acredita na possibilidade de eliminá-lo ao assumir e explicar as lacunas documentais por meio do entrelaçamento/ comparação das fontes e estudo do contexto (LIMA, 2007, p. 109). Mesmo admitindo os limites da investigação, o historiador italiano defende a existência de procedimentos que permitem ao pesquisador alcançar o conhecimento histórico, como não excluir da análise aquilo que é fugaz e transitório, pois são indícios, sinais para ler os documentos além do que é intencional, aparentemente evidente (LIMA, 2007; GINZBURG, 2002b).

Outra crítica de Veyne (2008) e principalmente de Certeau (2008) é que, para transmitir um sentido de objetividade, a história supre do seu discurso o lugar de onde ela se enuncia. Para Certeau (2008, p. 66), “toda pesquisa historiográfica se articula com um lugar 
de produção socioeconômico, político e cultural", mas que negado, impede uma explicação dos métodos, documentos e questões a partir desse lugar.

Estes apontamentos sobre a relação entre prova e retórica, o caráter lacunar da história, a crítica documental e o discurso histórico são temas recorrentes na historiografia, porém situá-los no contexto de nossa pesquisa, ou seja, em uma investigação que se fundamenta em transcrições de entrevistas, permite expressá-los de uma forma não generalizada, e, consequentemente, introduzir novos olhares sobre os limites e oportunidades da história oral.

Como esse campo do conhecimento desenvolveu suas próprias metodologias, um dos nossos interesses foi discutir em que medida seus métodos e procedimentos reforçam ou refutam algumas dessas características da história apresentadas por Certeau, Veyne e Ginzburg, como influenciam a relação com os entrevistados e a produção de um texto final.

Um dos aspectos citados é que o pesquisador não expõe o lugar de onde ele se enuncia, impedindo que o leitor questione o discurso em relação à posição social do autor. Concordamos que em qualquer texto há proibições e silenciamentos, no entanto, na história oral, uma das obrigações do pesquisador é exatamente se dispor a dialogar e inserir no texto as diferentes interpretações dos entrevistados a partir de uma autoridade compartilhada ou história colaborativa ${ }^{19}$, realizando e explicitando a comparação entre as fontes dentro da própria escrita. Assim, o leitor tem acesso ao processo de argumentação, às contradições que se transformam em indícios e às evidências que se sustentam inclusive nessas diferenças, pois são através delas que o autor poderá comparar, questionar e, retoricamente, apresentar os caminhos do provável. Nesse sentido, ao contrário da crítica de Veyne (2008, p. 27) de que "as lacunas da história se fecham espontaneamente a nossos olhos e que só as discernimos como esforço", elas se transformam em um recurso para alcançarmos o saber. É verdade que isso não resolve o problema, mas não negar a existência de exclusões, esquecimentos e a impossibilidade de um discurso totalizante reforça a disponibilidade dessa metodologia para questionar os seus lugares de enunciação.

Ao invés de revelar a fragilidade e inconsistência da história oral, explicar os procedimentos de coleta de dados e análise a partir do meio de sua elaboração não exclui a concepção de que a história tem critérios e regras, mas obriga o pesquisador a expô-los e justificá-los, reforçando a ideia de que retórica e prova não são antagônicas.

\footnotetext{
${ }^{19}$ Segundo Rouverol (2003, p. 62-63, tradução nossa), "história oral colaborativa (...) envolve engajar nossos entrevistados na análise das entrevistas que produzimos e/ ou na criação de quaisquer produtos provenientes dessas entrevistas. Pesquisa colaborativa é baseada na premissa que autoridade não permanece exclusivamente nas mãos do pesquisador".
} 
A identificação da prova como núcleo racional da retórica, defendida por Aristóteles, se contrapõe, decididamente, à versão auto-referencial da retórica hoje difundida, baseada na incompatibilidade entre retórica e prova. Como foi possível remover, tão radicalmente, a tese central de um dos textos fundamentais da nossa tradição intelectual? Como foi possível dar por certa a ideia, profundamente ingênua, de que a noção de prova é uma ilusão positivista? (GINZBURG, 2002a, p. 74).

Ao trabalhar com entrevistas gravadas, o pesquisador seleciona trechos e os compara, sincrônica e diacronicamente, no próprio texto para desenvolver uma argumentação. Entretanto, tanto para o leitor como para aquele que cedeu a entrevista, não se oblitera que o que se insere das transcrições é apenas um fragmento entre tudo o que foi colhido, devido ao recorte temático e espaço-temporal do projeto. Se pesquisamos o que a população entende e classifica como patrimônio cultural, os intervalos selecionados serão aqueles que tratam desse assunto no período abrangido. Desta forma, ao contrário de induzir o entrevistado/ leitor a aceitar tal conclusão, ele é convidado a refletir e questionar as evidências e indícios apresentados. Assim sendo, a ideia de colaboração, tão citada na história oral, não se realiza apenas na produção da fonte, mas também na iniciativa do projeto de instigá-lo à crítica durante a leitura do texto final.

Um julgamento é que, ao receber o texto produzido pelo pesquisador, o entrevistado não se sentirá confortável para a crítica e muito menos para solicitar mudanças ao perceber o aspecto acabado, finalizado e conclusivo do documento. É por isso que em projetos que priorizam a participação e a mediação torna-se necessário sempre a valorização do interlocutor, demonstrando o seu papel e importância para o sucesso da pesquisa. Além disso, por mais que o colaborador atribua uma autoridade ao pesquisador, sua leitura sempre estará ligada às suas experiências e aos grupos aos quais ele pertence, o que desmistifica uma ideia de dominação e homogeneização interpretativa e enfatiza as diferentes formas de recepção, como faz Barbero (1983) ao discutir as relações entre a cultura de massa e popular.

Com este pressuposto, buscamos um diálogo contínuo com os participantes da pesquisa, sempre considerando os meios de contato e a linguagem a ser utilizada com cada pessoa e em cada momento. Desde o primeiro encontros, explicamos os nossos objetivos e a importância da colaboração para que eles fossem alcançados. Do mesmo modo, por sabermos que uma autoridade compartilhada também impossibilita que o pesquisador tenha controle de todos os desdobramentos do projeto, ainda discutimos os limites de cada intervenção, para que não houvesse dúvidas sobre as possibilidades de mudanças nos textos produzidos. 
Certeau (2008, p. 249) também observa que as citações (notas, remetimentos, inserções) estabelecem a falsa ideia de um "saber do outro", pois, ao serem recortadas e inseridas em contextos diferentes, perdem o seu significado primário. Para ele, desdobrando a história em discursos que não foram elaborados pelo pesquisador, o relato torna-se verossímil, produz credibilidade e reforça a autoridade daquele que os cita. Assim, "nesta posição na qual não tem mais nada de próprio, [a citação] permanece susceptível de trazer; como em sonho, uma estranheza inquietante: poder sub-reptício e alterador do recalcado" (CERTEAU, 2008, p. 249).

É verdade que em história oral esse risco é ainda maior por colocar a citação das entrevistas como o cerne do conhecimento, reforçando a ideia do outro. Em contrapartida, ao permitir que o entrevistado participe e leia os textos elaborados, ele é o primeiro a perceber como a sua fala é fragmentada e reempregada na escrita e, portanto, torna-se capaz de exigir mudanças que ao menos respeitem suas opiniões. Em nossa pesquisa, por exemplo, em um dos encontros com os participantes, uma entrevistada, Badra, expôs que percebera que um trecho de sua entrevista utilizado no texto não expressava bem o seu pensamento. Desta forma, pediu para reler e modificar algumas partes, o que foi incentivado. Porém, depois de uma nova leitura, a mesma disse que deixaria a transcrição como estava, pois concluiu que o parágrafo anterior escrito pelo pesquisador complementava e explicava o que ela desejou expressar no momento da entrevista. Logo, nesse percurso, a participante repensou as maneiras como as suas falas foram utilizadas no texto, as prioridades estabelecidas, e mais do que aquele trecho dizia, analisou os sentidos que ele adquiriu ao ser vinculado e comparado com outros discursos, seja dos colaboradores como do pesquisador.

Confortáveis para participar, os entrevistados expressaram suas impressões sobre os escritos produzidos, reclamaram por reformulações e inseriram correções, demonstrando disposição para rever seus argumentos e mesmo refletir sobre como a história estava sendo contada. Alguns dos participantes, como André, até solicitaram mudanças em suas transcrições não porque discordavam do que haviam dito, mas por acreditarem que o leitor poderia entender de uma forma não desejada o que eles queriam dizer. Assim sendo, além de divulgar suas opiniões, os entrevistados também questionaram as maneiras como cada texto poderia ser interpretado, mostrando-se atentos com o que gostariam ou não de ver publicado. Se isso significa que em alguns momentos eles evitaram entrar em temas polêmicos e constrangedores, por outro lado fez com que refletissem sobre as diferentes recepções dessa narrativa e, consequentemente, pensassem sobre como cada assunto abordado nas entrevistas era visto pela sociedade. 
Outro ponto é a natureza lacunar da história, reforçando a ideia de que ela é apenas uma interpretação subjetiva ou uma ficção que pode ser escrita de várias maneiras. Concordamos que a linguagem permite a apresentação da história em mais de uma forma e que um mesmo período pode ser abordado a partir de diferentes acontecimentos, mas não porque ela é incapaz de superar o relato, e sim pela necessidade de selecionar o que será estudado em um recorte espaço-temporal. $\mathrm{Na}$ história oral, especificamente, um conjunto de entrevistas nunca poderá ser visto como a síntese do social, uma explicação totalizante, mas respostas para perguntas desenvolvidas no presente. Como mostra Bloch (2001, p. 75), “o passado é, por definição, um dado que nada mais modificará. Mas o conhecimento do passado é uma coisa em progresso, que incessantemente se transforma e aperfeiçoa”.

O conhecimento histórico é produzido sob o olhar dos entrevistados, que, por não se distanciarem de sua produção, não são induzidos a pensar que os textos elaborados são a única forma de contar a história. Em nossa pesquisa, ao perceberem que a escrita privilegia certos assuntos e linguagem, os participantes não se intimidarem em solicitar mudanças ou revisões, pois sabiam que por trás de cada trecho podia haver interesses (da pesquisa, do pesquisador, da universidade, etc.) que muitas vezes não eram os deles ${ }^{20}$.

E por fim, ao questionarmos a possibilidade do entrevistado ser um produtor/ autor consciente de seu discurso ou apenas um reprodutor de convenções e representações sociais, concluímos que nossa posição não se encontra em nenhuma das extremidades, mas na capacidade de crítica e reflexão do indivíduo, ou seja, uma característica de autonomia, sem se desvincular, o que consideramos impossível, do meio no qual ele se situa, que o influencia. Ginzburg (2009, p. 10), por exemplo, utiliza as relações entre as classes dominantes e subalternas para defender a noção de "circularidade", emprestada de Mikhail Bakhtin. Para ele, não há nem dominação nem autonomia absoluta entre essas classes, e as criações culturais se desenvolvem em um sistema de trocas que permite um equilíbrio das forças. No nosso caso, recorremos à noção de circularidade para pensar a relação entre o individual e o social, e ao invés de privilegiar apenas um aspecto da memória, como muitas vezes se fez ao pensá-la somente por quadros coletivos, também discutimos a sociedade por meio de discursos individualizados. Ao mesmo tempo, a escrita dos textos se fundamentou em uma relação dialógica, de contato contínuo, na qual pesquisador e entrevistados negociavam o que era de

\footnotetext{
${ }^{20}$ Para Certeau (2008, p. 76-77), "antes de saber o que a história diz de uma sociedade, é necessário saber como funciona dentro dela. Esta instituição se inscreve num complexo que lhe permite apenas um tipo de produção e lhe proíbe outros. Tal é a dupla função do lugar. Ele torna possiveis certas pesquisas em função de conjunturas e problemáticas comuns. Mas torna outras impossiveis; exclui do discurso aquilo que é sua condição num momento dado; representa o papel de uma censura com relação aos postulados presentes (sociais, econômicos, políticos) na análise".
} 
interesse tanto para a pesquisa como para aqueles que se dispunham a defender e publicar suas opiniões, fazendo das fontes orais não somente um material de consulta, mas um instrumento para provocar reflexões. 


\section{OS COLABORADORES}

Antes de iniciarmos uma discussão sobre a cidade de Santa Rosa é necessário apresentar o percurso realizado até a seleção da amostragem que possibilitou as entrevistas utilizadas na dissertação. É por meio desta explicação que o leitor adquirirá as informações para melhor entender o que foi desenvolvido em cada um dos dois capítulos seguintes.

Considerando os aspectos qualitativos da pesquisa, nossa prioridade foi estabelecer um diálogo tanto com os atuais responsáveis pela área cultural da cidade (dirigentes do Departamento de Cultura, Fundação Cultural, entre outros), assim como com pessoas que estão mais distantes desse círculo administrativo, mas que também manifestam ou já manifestaram interesse e preocupação pela cultura local.

Inicialmente, acreditamos que a Sociedade de Amigos da Cultura Santa-Rosense (SACS), criada em 1995 com a intenção de apoiar e auxiliar as instituições culturais da cidade a conseguir convênios, doações em dinheiro ou obras, além de prestar serviços para a realização de eventos, seria o lugar ideal para encontrarmos pessoas interessadas em discutir os temas da dissertação ${ }^{21}$. No entanto, a partir de informações sobre os presentes na lista de participantes e pela Sociedade já ter sido extinta, verificamos que muitos dos citados eram pessoas que estavam muito distantes de nossas preocupações e das discussões culturais da cidade. Desta forma, seria importante ampliarmos o quadro de indivíduos e nos encontrarmos com pessoas que são referências para o tema não somente no passado, mas principalmente no presente e possivelmente no futuro.

Com os nomes e informações sobre os participantes da Sociedade de Amigos da Cultura Santa-Rosense, verificamos que Boniperti Pádua Cota, 34 anos, além de ter participado desta Sociedade, foi integrante da Banda Sinfônica, presidente da comissão organizadora da Semana Universitária Santa-Rosense (SUSA) em 1998, e atual professor e diretor de uma escola de Santa Rosa, se qualificando como um dos possíveis participantes do projeto.

${ }^{21}$ Pelas Atas das reuniões disponíveis na Fundação Cultural, observamos que a Associação não conseguiu realizar, plenamente, os fins presentes em seu Estatuto. Deste modo, em 30 de junho de 2003, decidiu-se pelo encerramento de seus trabalhos, pois, segundo seu presidente, Maurílio de Oliveira Júnior, "em razão da burocracia existente nos órgãos públicos, da dificuldade de encontrar voluntários para administrar a mesma, e ainda, da dificuldade de angariar recursos para sua manutenção, perdeu-se o objetivo de manter a entidade em atividade". 
Até os seis anos de idade, Boniperti viveu na Fazenda Amália, frequentando o grupo escolar na primeira série do ensino fundamental. No início da década de 80, seus pais migraram para a zona urbana, onde vivem até hoje. Aos 14 anos, Boniperti, sem os pais, se mudou para a cidade de Mococa, onde foi estudar. Posteriormente, foi para Campinas, onde cursou Pedagogia na universidade estadual da cidade, UNICAMP. Mesmo longe, retornava todos os finais de semana para Santa Rosa, pois era integrante da Banda Sinfônica, na qual permaneceu por dezenove anos. Segundo seu relato, a banda sempre foi seu vínculo com Santa Rosa, permitindo manter os laços de amizade estabelecidos anteriormente e participar da vida social da cidade. Depois de retornar e se estabelecer novamente em Santa Rosa, Boniperti saiu da banda e assumiu alguns cargos administrativos e políticos, como assessor de cultura e diretor de educação. Hoje, como dissemos, é diretor e professor de uma das escolas da rede particular de Santa Rosa, e apesar de não exercer nenhum cargo político, acompanha e mantêm relações com aqueles que administram o setor cultural.

Ainda, em visita às instituições culturais de Santa Rosa, conhecemos o projeto do Estado de São Paulo, Acessa SP, dirigido por Suzana Bassi Fukushima, 21 anos, nas dependências da biblioteca municipal e que tem chamado a atenção de jovens para o acesso à informação na Internet. Concomitantemente, a mesma, na época das visitas, estava se preparando para assumir o Centro de Memória de Santa Rosa, também a ser instalado na biblioteca.

Suzana nasceu em Santa Rosa, filha de santa-rosenses, e, como muitos outros jovens da cidade, só se mudou quando, aos 18 anos, passou no vestibular em Ribeirão Preto, cidade próxima, e foi cursar licenciatura em Química. Nesse ano, morou um semestre nessa cidade, quando desistiu do curso. Retornou para Santa Rosa, foi aprovada em um concurso municipal, assumindo o projeto Acessa SP nas dependências da biblioteca, que constitui no oferecimento de acesso gratuito à Internet para a população de baixa renda, além de estimular o desenvolvimento de projetos relacionados à inclusão digital. A partir desse momento, Suzana começou a se envolver com os administradores culturais da cidade, pois além de ser subordinado à prefeitura, seu trabalho está diretamente relacionado com as áreas de educação e cultura. Em 2007, depois de prestar vestibular novamente, ingressou no curso de Ciências da Informação e Documentação, também em Ribeirão Preto, onde está até hoje. No entanto, por possuir um trabalho na cidade, Suzana optou por viajar diariamente para Ribeirão Preto nos ônibus destinados aos estudantes, como faz a maioria dos jovens da cidade nesta situação.

Por cursar uma graduação que discute a organização de documentos, foi convidada, em 2009, para assumir o Centro de Memória, que está em fase de implementação e que 
pretende organizar e oferecer ao público documentos históricos sobre a cidade. Entretanto, a sua função no projeto Acessa SP foi mantida, cabendo a conciliação das duas atividades. Aliás, no ano de 2010, o Governo do Estado de São Paulo escolheu Suzana como a idealizadora do segundo melhor projeto ativo do Acessa SP, o Acessa Cinema, que consistiu na exibição de filmes sobre tecnologia para usuários do posto local, que discutem e publicam suas opiniões sobre o evento em um blog criado por Suzana.

Portanto, como ponto zero de nossas entrevistas, acreditamos que estas duas pessoas poderiam se mostrar interessadas em discutir a cultura na cidade e, ao mesmo tempo, apresentar informações relevantes para a pesquisa. Para isto, marcamos uma entrevista individual com cada uma para posteriormente rever os passos tomados até aquele momento e selecionar os demais a serem contatados.

Logo nessas duas primeiras entrevistas, observamos que os entrevistados, sem qualquer solicitação, citavam e justificavam o encontro com outras pessoas da cidade, apresentando os motivos para que entrássemos em contato e fizéssemos as mesmas perguntas. Analisando esses nomes, constatamos que alguns deles condiziam com o perfil desejado pelo projeto e que poderiam trazer alguma contribuição. Seguindo as indicações destes dois primeiros entrevistados, selecionamos mais três pessoas e demos continuidade à pesquisa, sendo duas citadas pelos dois primeiros, Romeu e Daniela, e uma pessoa de fora dessa rede, Cheyenne.

Daniela de Souza Santos, 20 anos, assim como Suzana, sempre viveu em Santa Rosa, apesar dos seus parentes mais próximos viverem na cidade vizinha de Cajuru, onde seu pai nasceu em uma fazenda e seus avôs paternos residem. Já sua mãe nasceu no Estado de Minas Gerais, pois, segundo Daniela, seus "avôs maternos já fizeram um trajeto de vida pior, aquele que viaja mais". Assim sendo, é comum Daniela passar os finais de semana na cidade vizinha. No ano de 2008, ela ingressou no Curso de Ciências da Informação e Documentação em Ribeirão Preto, no qual conheceu e se aproximou de Suzana, que viaja com ela no ônibus de estudantes. Na época da entrevista, Daniela estava trabalhando no Acessa SP na biblioteca municipal, enquanto Suzana se preparava para assumir o Centro de Memória. Apesar de nunca ter vivido fora de Santa Rosa, Daniela revelou certo "estranhamento" em relação à cidade, pois como não tem uma história familiar relacionada ao local, só conhece alguns fatos referentes à Santa Rosa através dos relatos de outros moradores. A maior contribuição do perfil de Daniela para a pesquisa é que, como uma jovem universitária, uma das suas maiores preocupações no momento da entrevista era o tema do emprego, planejando, inclusive, se mudar para Ribeirão Preto por acreditar que encontraria melhores oportunidades profissionais. 
Outro entrevistado foi Romeu José Antunes, 59 anos. Natural de Santa Rosa e com pais que passaram toda a vida na cidade, Romeu presenciou os acontecimentos que transformaram a zona urbana de Santa Rosa principalmente a partir da década de 1960. Durante sua vida, passou apenas alguns períodos vivendo em Ribeirão Preto e Campinas, totalizando em torno de três anos. Morador do centro, Romeu manteve e mantém contatos com as primeiras e mais tradicionais famílias da cidade, apresentando um percurso diferente daqueles que viviam na Fazenda Amália e estabeleceram suas relações sociais a partir desse lugar. Jornalista, sempre se preocupou com a história da cidade, preservando em seu acervo particular, jornais, documentos, fotografias e entrevistas sobre Santa Rosa e seus moradores. Com este material, escreveu dois livros sobre a cidade: Histórias de Santa Rosa de Viterbo (2000) e Pedras fundamentais de Santa Rosa de Viterbo (2006). Reconhecido pelos seus conhecimentos, é convidado com frequência a contribuir com discussões sobre a história e cultura santa-rosense, publicando, com regularidade, artigos no principal jornal de Santa Rosa, O Jornalzão. No ano de 2010, por exemplo, foi um dos idealizadores de um álbum comemorativo de figurinhas com imagens históricas da cidade vendido nas bancas locais. Devido ao seu envolvimento, além de uma entrevista, Romeu ainda colaborou com o nosso projeto cedendo fotografias do seu acervo e revisando informações sobre eventos que ele conhece e/ou presenciou.

Na mesma época, também conversamos com Cheyenne Morena Menegassi, 29 anos. Nascida em Summertown, uma comunidade do Estado americano do Tennessee com menos de quatro mil habitantes no ano 2000, Cheyenne passou os três primeiros anos de sua vida nos Estados Unidos. Posteriormente, retornou ao Brasil com sua família, primeiro se estabelecendo no Estado de Minas Gerais e depois na cidade vizinha à Santa Rosa de Viterbo, Tambaú, onde passou sua infância e adolescência. Devido à proximidade, visitava Santa Rosa em algumas ocasiões. Aos 18 anos, Cheyenne retornou aos Estados Unidos, morando por sete anos em algumas cidades desse país. Quando voltou ao Brasil, se transferiu para Santa Rosa, onde sua mãe havia aberto uma escola de inglês. A partir de então, começou a dar aulas de inglês na escola de sua mãe, em escolas de cidades vizinhas e em algumas do ensino fundamental e médio de Santa Rosa. Morando há cinco anos na cidade, Cheyenne não conhece a história local por experiência pessoal, até porque não possui familiares em Santa Rosa, mas espalhados pelo Rio de Janeiro e Rio Grande do Sul. Sua visão sobre a cidade é construída a partir das conversas com alunos, na sua grande maioria composta por adolescentes. Como também frequenta os bares e outros espaços de lazer da cidade, muitas destas conversas acabam se estendendo para fora dos espaços escolares. Portanto, por ter 
estabelecido um contato contínuo e duradouro com jovens da cidade, além de possuir informações para comparar suas opiniões com adolescentes de outras cidades ou mesmo de diferentes estratos sociais dentro de Santa Rosa, acreditamos que esta moradora seria uma pessoa capaz de discutir, além de suas impressões sobre a cidade como uma habitante relativamente recente, as percepções dos jovens em relação a esse espaço.

Em prosseguimento, verificamos que os demais entrevistados também sugeriam nomes, formando uma rede social que, a nosso ver, poderia aumentar o interesse dos mesmos pelos textos ao mesmo tempo em que incentivar a discussão dos tópicos propostos entre conhecidos. Assim sendo, além das características individuais, também passamos a considerar as relações sociais de cada possível entrevistado, pois observamos uma maior probabilidade de envolvimento dos participantes quando entre as opiniões expressadas está a de um conhecido.

Ainda nesse momento, quando procurávamos conversar com um grupo de moradores mais jovens, entrevistamos Paula ${ }^{22}, 25$ anos. Natural de Santa Rosa e de família santa-rosense, Paula só saiu da cidade quando foi cursar Farmácia em Londrina. Depois de formada, trabalhou um ano e meio na cidade de Toledo, no sul do Paraná, mas logo em seguida retornou para Santa Rosa, onde vive e trabalha como farmacêutica, seja da prefeitura como de farmácias particulares. Segundo a própria entrevistada, ela seguiu um caminho inverso dos colegas, pois decidiu voltar à cidade onde nasceu, vista por muitos como um lugar de poucas oportunidades. Em seu núcleo familiar, apenas a bisavó foi moradora da Fazenda Amália, apresentando-se como uma família com poucos laços afetivos com a zona rural. De qualquer modo, como sua avó é proprietária de uma loja na cidade, percebe que as decisões das indústrias localizadas na fazenda, como a demissão de funcionários, influenciam diretamente no comércio local.

Em alguns momentos, encontramos outros indivíduos que poderiam contribuir para o projeto e, mesmo não sendo citados pelos participantes anteriores, os entrevistamos seja pelas informações que poderiam transmitir como para diversificar os colaboradores, possibilitando outros caminhos de análise além dos apresentados pela primeira rede social. Os motivos para a escolha de cada participante foram vários, desde o interesse pela história local como conhecer várias cidades desta e outras regiões, permitindo comparar Santa Rosa com outras representações de cidade do interior. Assim, acreditamos que mesmo entrevistando um

\footnotetext{
${ }^{22}$ Nome fictício a pedido da entrevistada.
} 
pequeno grupo de pessoas, conseguimos abranger uma significativa diversidade de perfis e, principalmente, uma expressiva qualidade de indivíduos selecionados.

Para finalizar o contato com moradores de até 30 anos, que não são os responsáveis pelo setor cultural, mas se interessam pelos assuntos locais, entrevistamos Mateus de Paula Silva, 29 anos. Morador de Santa Rosa até a adolescência, saiu da cidade para frequentar o ensino médio em Ribeirão Preto. Logo em seguida, seguiu para a Índia como participante de um intercâmbio. De volta à Santa Rosa, prestou vestibular e foi estudar Interpretação no Rio de Janeiro, onde vive desde 2000. Entretanto, apesar da distância, sempre vem à cidade, passando, inclusive, longas temporadas, como em 2009, quando ficou praticamente todo o ano na casa dos pais. Em sua família, encontram-se moradores provenientes tanto da zona rural como urbana de Santa Rosa. Os bisavôs de sua mãe eram imigrantes italianos que se estabeleceram na Fazenda Amália para o trabalho na lavoura, enquanto os bisavôs paternos estavam entre os primeiros moradores da zona urbana, "nas primeiras quatro casinhas da Rua do Comércio". Como ator e ex-integrante da comissão que organizou a Semana Universitária Santa-rosense nos anos de 1999 e 2000, Mateus se mostrou interessado em discutir o que a cidade oferece de atividades culturais para os seus moradores e o que poderia ser feito para melhorá-las.

Após os encontros com estes representantes da população santa-rosense e que, em alguns casos, mantêm relações com os administradores do setor cultural, partimos para entrevistas com os responsáveis pelos projetos e atividades culturais da cidade. A seleção dos participantes nesta fase apresentou-se mais simples devido às poucas instituições locais e pessoas envolvidas com o assunto. Deste modo, procuramos a participação daqueles que tem o poder de decisão em questões culturais e que administram os lugares, atividades e ações citados pelos primeiros entrevistados.

Quando iniciamos conversas com moradores de outras faixas etárias e que estão diretamente relacionados com as decisões do setor cultural em Santa Rosa, um dos primeiros entrevistados foi Maurílio de Oliveira Júnior, 51 anos. Natural de Ribeirão Preto, mudou-se para Santa Rosa quando ainda era criança. Na adolescência, estudou violão com um músico da cidade, Emílio Queiroz, que era o responsável pela Banda Cecília. Após ser aprovado no vestibular, retornou para Ribeirão Preto, onde estudou Química Industrial e licenciatura em Química. Porém, devido ao seu interesse pela música, decidiu abandonar a carreira de químico e ingressou no curso de Música, no qual estudou violão. Nessa época, o prefeito de Santa Rosa, Nagib Moussa, convidou Maurílio para trabalhar com uma banda de música na cidade. No início, ele passava apenas uma parte da semana em Santa Rosa, mas com o 
sucesso do trabalho, acabou se mudando definitivamente. Responsável por um dos principais projetos culturais da cidade, a Banda Sinfônica, Maurílio também começou a participar de outras iniciativas municipais no setor, sendo uma figura constante nas suas decisões desde a criação da Fundação Cultural em 1985. Segundo o entrevistado, mesmo em cargos diferentes, sempre esteve envolvido nas discussões sobre atividades e espaços culturais na cidade, seja como "líder da cultura, como presidente, diretor do departamento empregado, outra hora só como maestro ou colaborador". Atualmente, Maurílio exerce a função de maestro da Banda Sinfônica e Diretor Cultural do município, e como a principal figura na realização de atividades culturais nos últimos 25 anos, especialmente pela regularidade e continuidade do seu trabalho, acreditamos que a sua contribuição apresenta um quadro deste setor na cidade.

Entre aqueles que participam da administração atual, também entrevistamos o Diretor da Educação, Válter Pereira da Silva, 40 anos. Morador de Santa Rosa, viveu na cidade até os 17 anos, quando foi cursar Técnico Agrícola na cidade vizinha de Santa Rita do Passa Quatro, onde residiu por três anos. Depois de formado, transferiu-se para São Paulo para trabalhar em uma cooperativa japonesa. Durante um curto período, também morou na cidade de Guariba. Segundo sua opinião, a construção de espaços culturais poderia modificar e ampliar as atividades que a cidade hoje oferece e até mesmo modificar a percepção da população sobre elas: "acredito que com a construção do anfiteatro, aos poucos vai se construir uma nova linguagem cultural, pois teremos acesso a peças teatrais, musicais, apresentações, etc., ampliando assim a visão de cultura".

Outra importante contribuição foi de Omar Nagib Moussa, 48 anos. Arquiteto, membro de uma família envolvida com as questões da cidade, primeiro participou da administração de seu pai, Nagib Moussa, ex-prefeito já falecido, como presidente da Fundação Cultural na década de 80 , sendo neste mandato que as políticas culturais começaram a ser instituídas com a criação da própria fundação e da Banda Sinfônica. Posteriormente, o próprio Omar elegeu-se prefeito, administrando a cidade entre 1993 a 1996. Em sua participação no setor cultural, foi um dos que propôs a reforma da cadeia desativada para a transferência da sede da Fundação Cultural. Atualmente, depois de um período afastado da política, ocupa o cargo de Diretor de Obras do município.

Acompanhando essas transformações estava Badra Farah Antunes, 69 anos. Natural de São Paulo e moradora de Ribeirão Preto até 1981, mudou-se para Santa Rosa com os filhos e marido que tinha parentes na cidade. Nesse período, seu marido abriu um restaurante, que segundo Badra, passou por dificuldades devido à dependência de Santa Rosa em relação à Fazenda Amália, pois, quando funcionários eram demitidos, o comércio local era fortemente 
prejudicado. Em 1983, assumiu o cargo de assistente social da prefeitura, mantendo-se na função até 1989, quando se elegeu vereadora e foi afastada de sua antiga função. Em 1992, quando encerrou seu mandato, foi convidada pelo prefeito da época, Omar, a reassumir o cargo, onde permaneceu por cinco meses. Em seguida, tornou-se assistente social do Fórum da cidade de São Simão, onde ficou até 1998. Envolvida com as questões políticas da época, realizava encontros com a população na creche que administrava. Durante o dia, atendia mães e crianças. À noite, promovia reuniões e assembleias com trabalhadores rurais da Fazenda Amália, discutindo seus direitos, reivindicações e greves.

Se nos preocupamos em conversar com pessoas que realizaram significativas contribuições na cidade nas décadas antecedentes, também entrevistamos aqueles que hoje são importantes formadores de opinião. Entre eles está André Nagib Moussa, 42 anos. Natural de Santa Rosa, André viveu na cidade até se mudar para estudar e trabalhar, quando permaneceu fora por seis anos. De volta à Santa Rosa, criou, em 1994, o jornal semanal $O$ Jornalzão, que se transformou no principal meio de comunicação do município. Com uma tiragem atual de 3.000 exemplares semanais, é através dele que a população se informa sobre os acontecimentos da cidade, as decisões políticas e questões sociais, inclusive do passado nas seções que contam a história local. Ainda, é nele que alguns moradores divulgam suas reclamações, agradecimentos, fotos familiares, etc., pois sabem que serão vistos/lidos pelos seus conhecidos. Portanto, ao entrevistá-lo, discutimos não somente as opiniões pessoais daquele que coordena a principal fonte de informação dos moradores, mas também quais ele acredita ser da população, pois, segundo o mesmo, a equipe recebe muitas reclamações, críticas e elogios sobre os serviços que a cidade oferece.

Por fim, nos encontramos com Maria Estela Belavenuto Esteves, 53 anos. Filha de antigos moradores da Fazenda Amália, Estela saiu da cidade aos 17 anos, quando foi trabalhar em São Paulo. Casada com um engenheiro agrônomo do Estado, também santa-rosense, os dois viveram em diferentes cidades do Estado de São Paulo, até retornarem definitivamente para Santa Rosa há 25 anos. Professora da rede estadual de ensino, uma de suas preocupações era oferecer meios para que as crianças da cidade pudessem conhecer a história local. Como não encontrou material destinado a este grupo, escreveu o livro intitulado Yara do Rio Pardo, que segundo a mesma, é de "fácil leitura", permitindo o seu uso por crianças e professores em sala de aula. De acordo com a entrevistada, seu objetivo não é exercer o papel de historiadora, mas compilar e organizar informações sobre a cidade para um público que não é considerado nas publicações tradicionais. Nesse sentido, também é uma das organizadoras da Revista local Pardo e do site PardoInform.com, que iniciaram suas publicações no ano de 2009. 
Ao todo, solicitamos a realização de entrevistas com dezessete moradores, o que se concretizou com treze. Os demais, ao longo dos primeiros contatos, desistiram de participar, pois não se sentiam confortáveis para tanto, não gostariam de publicar suas opiniões, etc. Além disso, mantemos conversas informais com outros habitantes de Santa Rosa, visitamos as instituições da cidade, como a Fundação Cultural, a biblioteca municipal e o Centro de Memória, para recolher informações que serviram como indícios para a escolha dos temas a serem discutidos posteriormente.

Em relação aos lugares dos encontros, seis foram realizados nos locais de trabalho dos participantes e sete em suas respectivas casas. Podemos perceber que as entrevistas feitas em casa possibilitaram um maior desenvolvimento dos assuntos a serem discutidos, pois os indivíduos possuíam uma maior disponibilidade de tempo e raramente eram interrompidos por outras pessoas. Já no ambiente de trabalho, era mais comum a necessidade de atender outras solicitações e delimitar o tempo disponível para a conversa. Também foi observado que, no trabalho, os participantes tendiam a assumir uma postura mais formal, e em alguns casos preferiam inserir seus posicionamentos em contextos mais gerais. Por outro lado, os que estavam mais distantes das decisões administrativas ou são moradores recentes reconheciam com mais frequência as suas limitações quando questionados sobre o que acreditavam ser a opinião dos outros habitantes ${ }^{23}$. De qualquer modo, todos os encontros realizados contribuíram para as discussões levantadas sobre a cidade e seus patrimônios culturais.

Por último, conseguimos selecionar habitantes de diversas idades, mostrando percepções e representações relativas a diferentes épocas. Dos treze participantes, um nasceu na década de 1940, três na de 1950, três na de 1960, três na de 1970 e três na de 1980.

Ainda explicamos que as entrevistas foram semiestruturas. Desse modo, tínhamos um conjunto de perguntas que serviram como roteiro para os encontros, mas inseríamos ou retirávamos questões/ tópicos de acordo com o posicionamento do entrevistado. A seguir, apresentamos este roteiro utilizado para a realização das entrevistas:

- Onde você nasceu?

- Você sempre morou aqui?

- Morou fora? Por quanto tempo? Durante qual período?

- Sua família é daqui?

\footnotetext{
${ }^{23}$ Cheyenne, por exemplo, recorreu algumas vezes ao argumento que suas opiniões eram fruto daquilo que ouvia dos seus alunos. Já Daniela afirmou que para alguns temas ela não podia emitir opinião porque sua família não é de Santa Rosa e que ela viaja com frequência para Cajuru.
} 
- Se você fosse para outra cidade e lhe perguntassem "como é Santa Rosa", o que você falaria? (do que você gosta e do que você não gosta, qualidades e defeitos, o que é bom, o que é ruim).

- Como você vê a cultura na cidade? Por quê?

- O que você pensa quando ouve a palavra "cultura"?

- O que você gostaria de ver na cidade, algo que ela tivesse em relação à cultura? Por quê?

- Como você acha que a cidade é vista pelos seus moradores? Por quê?

- Como você acha que a cidade é vista por aqueles que apenas a visitam ou ouvem falar dela, ou seja, são de fora da cidade? Por quê?

- Se você recebesse uma visita e ela lhe pedisse para você mostrar a cidade a ela, um lugar, uma festa, um evento que você acha que lembra Santa Rosa, que é "a cara" da cidade, o que você mostraria? Por quê?

- Você acha que (X) deveria ser mais valorizado na cidade? Por quê?

- Como você acha que estes lugares/ eventos/ manifestações são vistos pela população? E pelos políticos e responsáveis pela área cultural da cidade?

- Se a cidade tivesse um museu, o que deveria ser mostrado lá sobre a cidade?

- Você acha que Santa Rosa possui patrimônios culturais? Por quê?

- O que você pensa quando ouve as palavras "patrimônio cultural"? 


\section{MEMÓRIA E HISTÓRIA DOS USOS DA CIDADE E DE SEUS BENS CULTURAIS}

Nos capítulos a seguir, procuramos, por meio das entrevistas realizadas, abordar as características que identificam Santa Rosa de Viterbo para os seus moradores e os discursos que autorizam denominar determinados bens culturais como patrimônios locais. Desta forma, utilizamos como eixo ordenador de nossas reflexões a observação da vida cotidiana, que nos indicou caminhos e indícios para compreender os valores atribuídos aos bens considerados representativos para a memória social.

Como desenvolvemos uma concepção de mediação e participação, os capítulos produzidos com o auxílio das transcrições foram enviados para os colaboradores que contribuíram para a sua versão final. Lendo os textos, estes puderam refletir sobre as suas opiniões e como elas foram inseridas e analisadas pelo pesquisador, incentivando-os à crítica, principalmente entre aqueles que trabalham com o setor cultural da cidade. Em decorrência, chegamos a uma ideia de patrimônio cultural que relaciona os resultados obtidos pela pesquisa de campo com discussões teóricas e documentos oficiais.

\subsection{FAZENDA GRANDE, CIDADE PEQUENA: RELAÇÕES ENTRE ECONOMIA E CULTURA EM UM MUNICÍPIO DO INTERIOR DO ESTADO DE SÃO PAULO}

Segundo o Instituto Brasileiro de Geografia e Estatística (IBGE), em 2007, dos 645 municípios que compõem o Estado de São Paulo, 440 ou 68,2 \% possuíam menos de vinte e cinco mil habitantes (IBGE, 2007). Se preferirmos abranger para todos aqueles que são considerados pequenos pelo IBGE, ou seja, com até cem mil habitantes, podemos dizer que 575 ou $89,1 \%$ das cidades do Estado são pequenas. No entanto, apesar da quantidade, raramente essas pequenas cidades são tratadas como objeto de estudo, seja por estarem longe dos grandes centros urbanos, por não possuírem instituições de pesquisa, como universidades, por não serem atrativas economicamente, turisticamente, entre outros. 
$\mathrm{Na}$ literatura brasileira, essas cidadezinhas são retratadas como lugares nos quais não há nada para se fazer, ver ou conhecer. Um exemplo está na obra de Monteiro Lobato, publicada em 1919, sugestivamente intitulada Cidades Mortas, que busca descrever as cidades do Vale do Paraíba em declínio econômico após o auge do café. Entre os municípios fictícios de seu livro está Oblivion, que em inglês significa esquecimento. Segundo o autor, dela desviou-se a civilização, as pessoas vivem do passado, o tempo passa lentamente e nada muda no lugar no qual o silêncio é uma constante: “A cidadezinha onde moro lembra soldado que fraqueasse na marcha e, não podendo acompanhar o batalhão, à beira do caminho se deixasse ficar, exausto e só, com os olhos saudosos na nuvem de poeira erguida além" (LOBATO, 2007, p. 27).

Pior ainda é a descrição do homem que vive nestes lugares. Lobato, um defensor da modernização do Brasil, provavelmente foi quem mais ajudou a sedimentar essa ideia negativa do homem do campo, descrevendo-o como alguém preguiçoso, que atrasa o desenvolvimento do país, desconfiado, abobalhado, muitas vezes violento, de trajes pobres, que não sabe falar direito e apresentar-se ${ }^{24}$.

Este funesto parasita da terra é o CABOCLO, espécie de homem baldio, seminômade, inadaptável à civilização, mas que vive à beira dela na penumbra das zonas fronteiriças. À medida que o progresso vem chegando com a via férrea, o italiano, o arado, a valorização da propriedade, vai ele refugiando em silêncio, com o seu cachorro, o seu pilão, a picapau e o isqueiro, de modo a sempre conservar-se fronteiriço, mudo e sorna (LOBATO, 1964, p. 271).

O caboclo é uma quantidade negativa. Tala cinquenta alqueires de terra para extrair deles o com que passar fome e frio durante o ano. Calcula as sementeiras pelo máximo da sua resistência às privações. Nem mais, nem menos. "Dando para passar fome", sem virem a morrer disso, ele, a mulher e o cachorro - está tudo muito bem; assim fez o pai, o avô, assim fará a prole empanzinada que naquele momento brinca nua no terreiro (LOBATO, 1964, p. 276).

\footnotetext{
24 Para Leite (1996, p. 81), a figura do caipira construída por Monteiro Lobato é bastante verdadeira e se distancia da visão idealizada e pitoresca comum da época. O que criaria a idéia de desvalorização seria o fato do autor apenas constatar situações e não buscar explicá-las. Entretanto, embasados pela nossa leitura, consideramos que as adjetivações de Lobato para o caipira são preconceituosas, pois parte de uma cultura que não é do homem que estuda, mas que critica seu modo de vida. É sabido que Monteiro Lobato era um nacionalista e tinha o intuito de enaltecer o "típico homem brasileiro", mas considerar o caipira um preguiçoso, inerte, feio, covarde não é apenas constatar características sem uma maior discussão, mas analisar uma cultura a partir de concepções proveniente de outro meio, que neste caso, ridiculariza o caipira.
} 
Posteriormente, já em uma conjuntura modernista, como no grupo Verde-amarelo ou Anta, formado pelos autores Plínio Salgado, Menotti del Picchia, Guilherme de Almeida e Cassiano Ricardo, encontramos a estereotipização inversa do homem e cidade do interior. Agora, ao contrário de mostrar o atraso e miséria do Jeca Tatu, o caboclo é descrito de modo "lírico e sonhador", em "uma "idealização de base sentimental"” (VELLOSO, 1993, p. 7), como nos versos de Menotti del Picchia em Juca Mulato (1982).

\begin{abstract}
Uma estrela a fulgir, disse da etérea altura: / "Fui eu que iluminei a tua choça escura / no dia em que nasceste. Eras franzino e doente. / E teu pai te abraçou chorando de contente... / - Será doutor! - a mãe disse, e teu pai, sensato: / - Nosso filho será um caboclo do mato, / forte como a peroba e livre como o vento! - / Desde então foste nosso e, desde esse momento, / nós te amamos seguindo o teu incerto trilho / com carinhos de mãe que defende seu filho! (DEL PICCHIA, 1982, p. 42).
\end{abstract}

Considerando essas diferentes abordagens presentes na literatura ${ }^{25}$ que influenciam o imaginário social, além de trabalhos produzidos pela academia, como O Parceiro do Rio Bonito de Antônio Cândido (originalmente publicado em 1964) e obras contemporâneas na História, Antropologia e Sociologia ${ }^{26}$, este capítulo busca discutir as relações entre economia e cultura em Santa Rosa de Viterbo. Para tanto, produzimos uma revisão de literatura, analisamos documentos públicos, recolhemos relatos de moradores da cidade (aqui apresentados pelos seus primeiros nomes) a partir da metodologia da História Oral, além do uso de fotografias.

O objetivo é apresentar e compreender as suas especificidades e as relações com cidades vizinhas e similares, como as várias existentes no Estado de São Paulo, principalmente através dos relatos dos moradores locais.

\footnotetext{
${ }^{25}$ Ainda encontramos representações do homem rural e do interior nas Artes, como na pintura de José Ferraz de Almeida Júnior, Caipira picando fumo (1893); no cinema, com os filmes de Amácio Mazzaropi; e até mesmo na história em quadrinhos, com o personagem Chico Bento, criado pelo cartunista Maurício de Souza para a Turma da Mônica.

${ }^{26} \mathrm{Na}$ Academia, podemos citar o trabalho de Queiroz (2006), Caipiras negros no Vale do Ribeira: um estudo de antropologia econômica, que ainda será discutido neste trabalho. Já na literatura, uma referência é a obra de Valdomiro Silveira, um dos primeiros literatos a se preocupar mais em apresentar o homem rural como ser humano do que ridicularizá-lo a partir do lugar onde vive, como discutiu Yatsuda (1983) na análise da obra do autor intitulada Leréias.
} 


\subsubsection{Fazenda grande}

Para conhecermos a cidade atual, que, segundo a Fundação Sistema Estadual de Análise de Dados (SEADE), possuía uma população de vinte e três mil e oito habitantes em 2009 (SÃO PAULO, c2007), devemos antes nos dirigir a uma fazenda que, ao longo do século XX, pertenceu a algumas das principais famílias do Brasil: Dumont, Schmidt e Matarazzo.

No início do século XIX, a área que hoje ocupa Santa Rosa de Viterbo era formada por fazendas de criação de gado. Com a chegada de mineiros e, posteriormente, o café a região, a criação de animais foi substituída pela lavoura. Em 1894, quando o local já era um distrito policial, Henrique Santos Dumont, filho de Henrique Dumont e irmão de Alberto Santos Dumont, comprou no município de São Simão uma fazenda que marcaria a história de Santa Rosa, a Fazenda Amália. Em 1910, a futura cidade foi elevada a município, mas é em 1920 que ocorreu outro acontecimento que a transformaria. Os herdeiros da fazenda vendem a propriedade para uma sociedade constituída pelo Conde Francesco Matarazzo, Conde Alexandre Siciliano e o coronel Francisco Schimidt, que a denominam Sociedade Agrícola Fazenda Amália. Já em 1931, o filho do Conde, Francisco Matarazzo Júnior, desfaz a Sociedade e compra a parte dos outros sócios, ligando definitivamente a história de Santa Rosa ao império da família Matarazzo (ANTUNES, 2000, p. 53-130).

É na Fazenda Amália que a maioria dos habitantes de Santa Rosa trabalhavam e/ ou viviam. Para se ter uma ideia, em 1940, quando a cidade possuía 9.195 habitantes, 7.400 estavam na zona rural e somente 1.795 na zona urbana. Com a estrutura de uma pequena cidade, a fazenda possuía hospital, cinema, clube, escola, estádio de futebol, armazém, igreja, pensão e moradia para os trabalhadores.

Como apresenta Correia (2001, p. 83), desde o século XIX difundiu-se no Brasil a prática de construção, por empresas, de casas para a moradia de seus funcionários. Na maioria das vezes denominada "vila operária", se caracterizava por "um padrão de moradia popular oposto à favela, ao mocambo e ao cortiço, supondo ordem, higiene e decência. O termo sugeria casas salubres e dotadas de ordem espacial interna, que se distinguia (...) [das] casas dos pobres urbanos" (CORREIA, 2001, p. 84). 


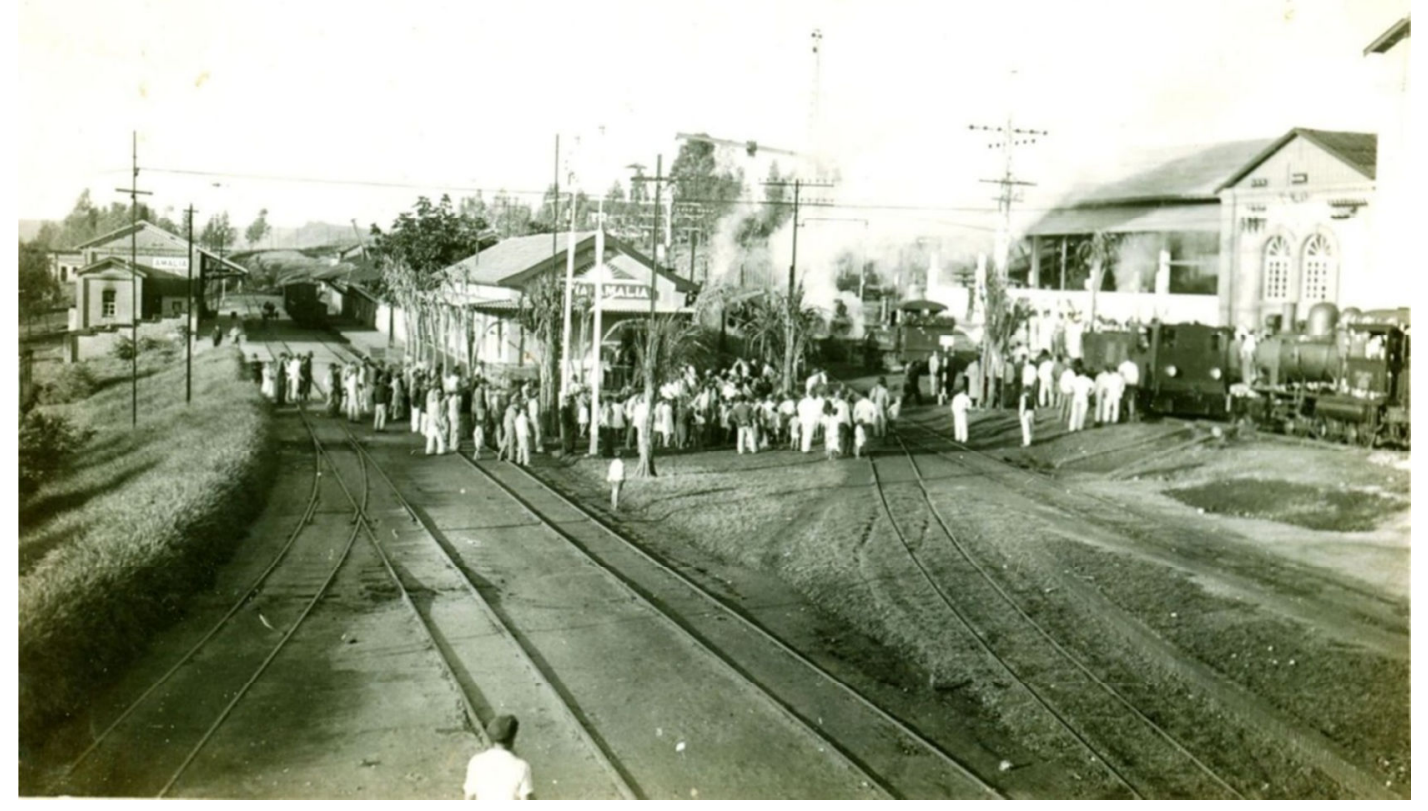

Fig. 2: Fazenda Amália na década de 1940 (I)

Devido à influência da família Matarazzo na administração de Santa Rosa e pela maior parte da população morar na fazenda, verifica-se que durante a primeira metade do século XX era a fazenda que possuía a cidade e não o contrário. Tal cenário fica evidente, por exemplo, ao observamos um relatório produzido sobre Santa Rosa em 1939 com a finalidade de descrever todos os seus aspectos, desde o clima, rios e ruas às diferentes construções. Enquanto toda cidade ocupa seis das nove páginas do documento, somente a fazenda recebe três, concentrando os elogios que não se verifica em outros trechos:

A sede da Fazenda Amália é uma verdadeira cidade possuindo cerca de 300 casas higiênicas e confortáveis com excelente água encanada, luz elétrica e todo conforto necessário.

Uma bela igreja do estilo campesino, sob a invocação de São Francisco, ergue ao céu sua cruz símbolo de paz e amor.

Conta a sede da Fazenda Amália com 6 escolas, sendo 5 estaduais e uma municipal. Acha-se em construção um prédio destinado a um Grupo Escolar.

Registra-se ainda na Fazenda Amália uma farmácia com sortimento completo de produtos químicos e farmacêuticos, assistência médica, grande armazém, loja, gabinete dentário, salão de barbeiro, padaria, um ótimo campo de futebol, quadra de tênis, oficina mecânica e dois auto-ônibus para os operários que residem em Santa Rosa de Viterbo.

O Palacete residencial está localizado em uma bela colina de onde se descortina um vasto e belíssimo panorama.

É pois com justificado orgulho, que Santa Rosa enumera entre os seus munícipes ilustres o Exmo. Sr. Conde Francisco Matarazzo Júnior (SANTA ROSA DE VITERBO, [1939?], p. 9). 
Assim como na citação anterior, é comum referir-se à fazenda como uma verdadeira cidade:

De Longe, com a casaria derramada em grupos e isoladamente, a Fazenda Amália se afigura aos olhos como uma cidade. A estrada de ferro atravessa toda a fazenda, tendo no centro a sua estação que da Fazenda tira o nome de Amália. (...) Em redor da estação Amália vê-se uma inteira cidade onde, entre os vastos armazéns de depósitos e fornecimentos de todos os gêneros domésticos, a moradia do proprietário e do administrador, os estabelecimentos industriais, surge a bela igreja de N. S. da Glória, erguendo ao céu a sua cruz (...) (CAPRI, 1913).

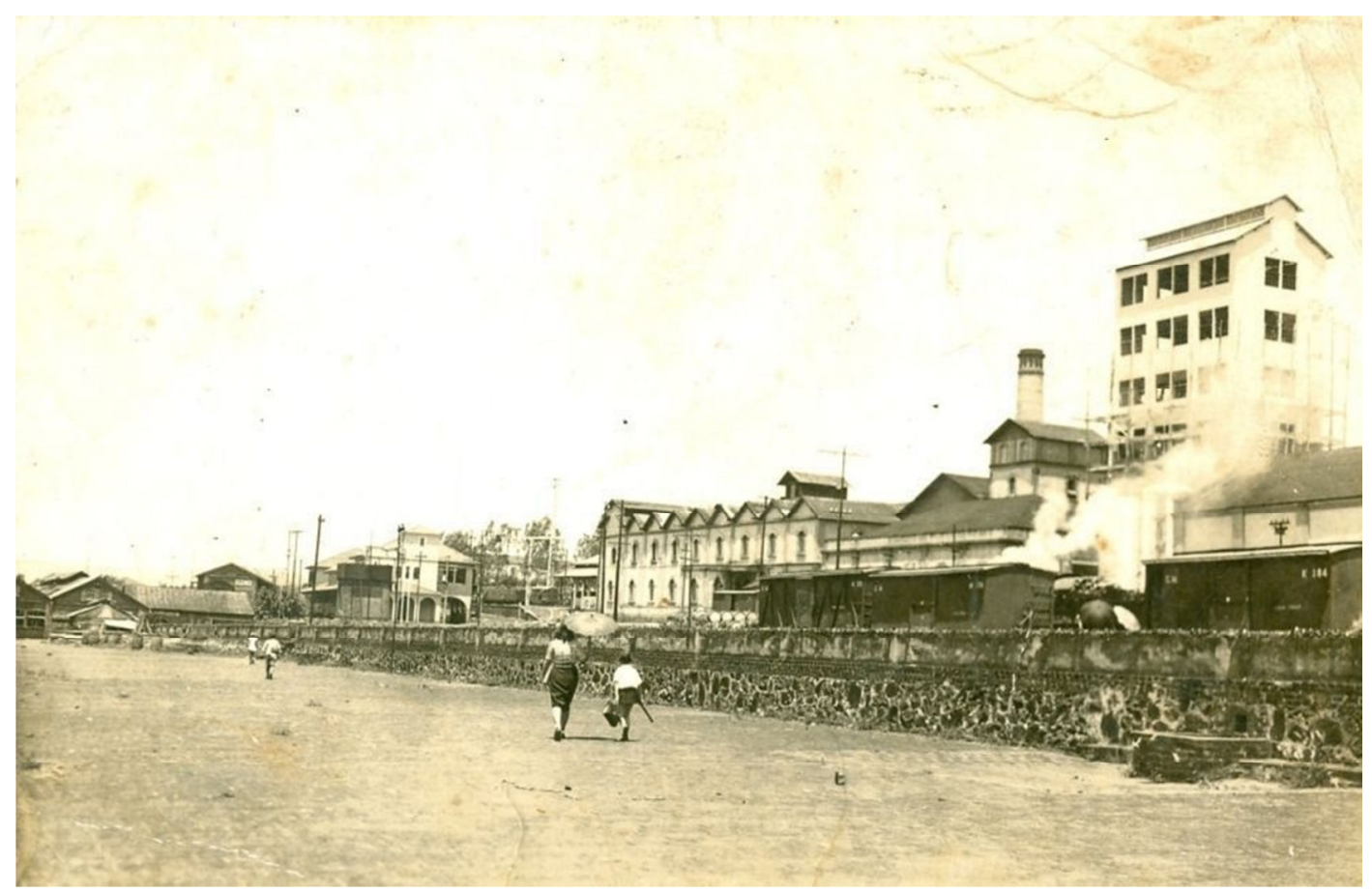

Fig. 3: Fazenda Amália na década de 1940 (II)

É verdade que os moradores da fazenda também precisavam ir à zona urbana de Santa Rosa para adquirir alguns produtos, como alimentos e roupas, mas como eram viagens esporádicas, geralmente uma vez por mês, não se configurava uma grande limitação da fazenda, mesmo com as dificuldades de transporte.

Assim como em documentos, encontramos representações positivas da fazenda entre os moradores. Um dos fatores que contribuíram para essas boas lembranças são as festas, que citamos por se configurarem como espaços de expressão, integração e sociabilidade, nas quais 
era possível se encontrar com os amigos e conhecer aqueles mais distantes, como observaram Amaral (1993) e Magnani (2007) na análise de diferentes modalidades de festas em outros contextos.

Dentro da fazenda, eram promovidas manifestações que nos ajudam a entender os costumes locais, como a Festa de Folia de Reis, Dança ou Festa de São Gonçalo, Congado, procissões e terços, encontro de violeiros e sanfoneiros. Apesar da Folia de Reis ser proibida na sede/ área central da fazenda, pois os guardas impediam a entrada dos integrantes, companhias visitavam as moradias mais distantes, denominadas colônias, para dançar e cantar a história cristã dos Três Reis Magos.

Em uma pesquisa sobre a Folia de Reis na cidade de Leme - SP, Silva (2001) encontrou pessoas que contam como a festa ocorria na Amália:

\begin{abstract}
$\mathrm{Na}$ Usina Amália era aquela carreira de casa, que a turma entrava de tarde. A coisa mais bonita é que quando batia numa colônia, outra companhia chegava e pegava de lá pra cá. Era o encontro de bandeira! Nossa Senhora, era gente igual formiga! Chegava o encontro de bandeira. Coisa linda era o encontro de bandeira!! Um embaixador canta de lá, e o outro embaixador canta daqui. Vão cantando, vão cantando, aí vai até trocar esmola. Aí, cruza as espadas, cruza as bandeiras, trocam as esmolas... E aquela segue o destino dela e a outra segue no destino dela novamente (SILVA, 2001, p. 108).
\end{abstract}

Outra manifestação era Dança ou Festa de São Gonçalo. Realizada em pagamento a promessas ao santo, a dança consistia na organização de duas fileiras de dançarinos, uma de homens e outra de mulheres, que sapateando se dirigiam ao altar, beijavam, agradeciam a São Gonçalo e voltavam para o final da fila, tudo ao som de violeiros. Também eram servidos alimentos a cada "volta" (depois que todos foram ao altar) e, ao final, os que estavam pagando uma promessa carregavam a imagem do santo.

Ainda podemos citar o Congado, manifestação afro-brasileira com elementos católicos que era realizada em homenagem a São Benedito, Nossa Senhora do Rosário e a coroação do Rei do Congo. O culto era acompanhado de música e dança, seja nas colônias da fazenda como na zona urbana, onde também era considerado uma atração.

Desta forma, pelo modo de vida e costumes apresentados, o morador da Fazenda Amália se enquadra na definição do caipira ${ }^{27}$, como estudado por Antônio Cândido:

\footnotetext{
${ }^{27}$ Segundo Santos (2006, p. 114-115), baseado nos escritos de Antônio Cândido e, principalmente, Donald Pierson, o termo caipira, já na década de 1940, tinha se modificado e passava a se referir a todo habitante de qualquer parte do país fora das cidades maiores.
} 
É preciso pensar no caipira como um homem que manteve a herança portuguesa nas suas formas antigas. Mas é preciso também pensar na transformação que ele sofreu aqui, fazendo do velho homem rural brasileiro o que ele é. "Tabareu", "matuto", "capiau", "caipira", o que mais haja, ele é produto e ao mesmo tempo agente muito ativo de um grande processo de diferenciação cultural própria. Na extensa gama dos tipos sertanejos brasileiros, poderia ser considerado "caipira" o rural tradicional do sudoeste e porções do oeste, fruto de uma adaptação da herança fortemente misturada com a indígena, às condições físicas e sociais do Novo-Mundo (CÂNDIDO, [19?]).

Luyten (1987, p. 91), por exemplo, ao apresentar as modalidades de música caipira, explica que a Dança de São Gonçalo é uma modalidade de Fandango, dança típica desta cultura. Já Queiroz (2006, p. 88-91), ao estudar os caipiras negros do Vale do Ribeira - SP, registrou uma Festa de São Gonçalo no ano de $1977^{28}$.

Ao mesmo tempo, encontramos a relação da cultura caipira com a Folia de Reis na literatura brasileira, que também conseguiu registrar o preconceito existente contra o "caboclo", como podemos observar em um trecho de Vila dos Confins, de Mário Palmério.

\begin{abstract}
O senhor já ouviu falar em festa dos Santos Reis? Então, escute. Lá um dia, caboclo resolve inventar um Santos Reis. Arranja estampa de santo, convida os compadres, cata porção de mulher e menino, e sai a manada batendo lata e cantando ladainha. De fazenda em fazenda, de rancho em rancho. Todo o mundo tem de arranjar pagode para os vagabundos, dar dia santo, parar com o custeio do gado, a capina na lavoura. E se a gente faz cara boa, a caboclada vai ficando...(PALMÉRIO, 1983, p. 152).
\end{abstract}

Posteriormente, com a instalação de indústrias na fazenda e a vinda de famílias para Santa Rosa, alguns traços desta cultura se diluiriam ou transformaram. No entanto, uma característica em Santa Rosa é que mesmo com o trabalho assalariado nas indústrias Matarazzo, as pessoas continuaram a viver na zona rural por mais alguns anos, suavizando a oposição campo X indústria, pois como observa Cândido (2003, p. 107), o modo de vida caipira não era baseado no "enquadramento do salário e do patrão, como eles lhe foram apresentados, em moldes traçados para o trabalho servil”.

\footnotetext{
${ }^{28}$ A obra de Queiroz (2006) é uma importante contribuição para os estudos desta cultura ao reafirmar que, apesar do caipira mais citado e conhecido ser o mestiço de indígena com português, o caipira não se refere a uma raça, mas a um modo de vida, como identificado na comunidade negra que norteou sua pesquisa.
} 
De fato, a circunstância que melhor explicita a oposição caipira X citadino é a do incremento da industrialização, que traz à tona a chamada ideologia da modernização. Nesse momento, para os defensores da incipiente industrialização, o caipira, enquanto representante do campo, torna-se símbolo do atraso. Mais do que isso, ele é mesmo tido como o elemento que impede o desenvolvimento da nação, agora centrado na zona urbana. Enfim, o caboclo é o entrave para que um país subdesenvolvido torne-se desenvolvido, como ingenuamente acreditavam alguns (YATSUDA, 1987, p. 104).

A relação e interdependência entre a fazenda e a zona urbana tornam-se mais clara quando observamos outra prática cultural, o futebol. Praticado seja no campo como na cidade, ele revela a rivalidade entre a Amália e a parte urbana de Santa Rosa, ao mesmo tempo em que expõe sua ligação, quando cada lado tem como parâmetro de qualidade e desenvolvimento a comparação com o outro. O futebol, como prática de lazer e sociabilidade, além de mostrar a expressividade da fazenda em relação ao centro urbano, também reforça as constantes trocas entre esses dois núcleos.

Romeu: Lá, naquele tempo, o que se desenvolvia muito era o futebol. O esporte faz parte da cultura de uma comunidade, então era o futebol que se desenvolveu. A Amália era uma coisa mais glamurosa, como se fosse uma cidade, mas as colônias eram pequenos detalhes na Fazenda Amália, e havia campeonatos internos. Aí se selecionava esse pessoal das colônias para fazer o grande time de Amália que disputava os campeonatos. Só que a Amália chegou a se desenvolver de tal maneira, a estrutura futebolística, que no começo dos anos 60 eles disputaram a terceira divisão do Campeonato Paulista, ou seja, uma coisa, hoje a série A3, A4, mas era uma coisa muito expressiva pra época, que Santa Rosa, a cidade, nunca conseguiu chegar nisso, sempre amador, nunca se profissionalizou. Lá chegou ao nível profissional a ponto de se contratar um técnico, que era o Aníbal, era uma referência, era o goleiro do Palmeiras, um grande goleiro do Palmeiras, do time do Palmeiras principal, e esse cara veio ser o técnico da Amália nesse campeonato. E se não me engano, a Amália foi campeã dessa série, aí não tinha estrutura pra passar pra segunda divisão, porque teria que fazer estádio, e o Matarazzo já tinha problema demais lá com essa coisa de muita gente morando na fazenda. $\mathrm{O}$ mundo mudou, se um monte de colônias acaba se tornando independente, ele perde as terras. Então, nesse torvelinho as coisas foram desmontadas.

Boniperti: (...) o centro de Santa Rosa tinha uma rivalidade muito grande com a Amália. Tinha o time daqui de Santa Rosa, “ - Oh, Santa Rosa ganhou da Amália”, isso era um vexame para Amália, e a mesma coisa o contrário, e assim vai. E há uma rivalidade, por quê? Quem morava em Amália? Os trabalhadores. A elite é mais tradicionalista que a Amália. Os trabalhadores da Amália vinham de todos os lados, muitos italianos, espanhóis, enfim, japoneses, vinha de todo lado, gente que vinha do Rio, gente que vinha de Minas, de todo lado. Agora Santa Rosa não, esse é o santa-rosense, é o Garcia Duarte, é o Fonseca inteiro, são esses os santa-rosenses. 


\subsubsection{Cidade pequena}

Com o aumento dos diretos do trabalhador rural na década de 1960, como promulgado pelo Estatuto do Trabalhador Rural de $1963^{29}$ (BRASIL, 1963), os empregados da Fazenda Amália, insatisfeitos, começaram a exigir melhores condições de trabalho, culminando em greve no ano de 1966. Aproveitando-se da situação, o grupo Matarazzo decidiu destruir grande parte das moradias distribuídas por toda a fazenda, forçando os seus moradores a mudança para a cidade. Esse êxodo rural é o que explica a prevalência de habitantes na zona urbana a partir da década de 1970 (ANTUNES, 2000, p. 218).

A mudança de famílias para Santa Rosa até o começo da década de 1980 fez com que a cidade ganhasse novos bairros, como as Cohabs, e grupos que viviam juntos nas colônias se dispersaram. Entretanto, como a maior parte da população continuou a trabalhar nas indústrias da fazenda, os laços sociais e com o lugar não se romperam definitivamente. Além do mais, pela cidade continuar pequena e com pessoas provenientes de uma mesma região possibilitou que a vida da fazenda continuasse presente na área urbana.

Boniperti: Se você chegou mais tarde, se chega com outra pessoa, enfim, se você tropeçou, usou uma roupa extravagante, as pessoas vão comentar. Isso é o preço que se paga por morar em um lugar onde todo mundo se conhece.

Suzana: (As pessoas dizem que é) uma cidade mais pacata, não tem tantos roubos e, quando tem, sempre aparecem nos jornais, então é o maior comentário.

Paula: Tem um ponto que é positivo e negativo ao mesmo tempo: as pessoas se conhecerem. É positivo porque fica um ambiente mais familiar, você sai na rua e conhece as pessoas, mas é ruim também porque uma notícia pequena se espalha rapidamente, todo mundo sabe da vida de todo mundo.

Provavelmente, a maior mudança foi no cotidiano daqueles que, como Romeu Antunes, já eram da cidade e viram o espaço urbano mais que dobrar em número de pessoas e moradias rapidamente:

\footnotetext{
${ }^{29}$ O Estatuto do Trabalhador Rural de 1963 foi promulgado durante o governo de João Goulart. Entre outras coisas, o Estatuto institui a obrigatoriedade de Carteira Profissional de Trabalhador Rural para o exercício da profissão, estipula o salário mínimo regional como pagamento, concede férias remuneradas, estabelece as normas para contrato de trabalho, etc. Na década seguinte, o Estatuto foi revogado pela Lei no 5.889, de 8/6/1973.
} 
Romeu: (A cidade) era um núcleo original, envolvia aqui o centro antigo até a Estação, mais ou menos, e não tinha da praça Pedro Cunalli pra Avenida Presidente Vargas, as Cohabs e o (bairro) Nosso Teto. De repente, com esse êxodo rural, acabou intensificando o desenvolvimento urbanístico nessas áreas e esse pessoal veio meio de repente morar aí, vieram as Cohabs, veio o Nosso Teto, ou seja, são três núcleos praticamente formados, e a cidade perdeu, em minha opinião, a identidade.

Com o êxodo, tradições populares existentes na fazenda se somaram às praticadas na cidade. Em um plano de desenvolvimento turístico para o município, elaborado pelos profissionais da Universidade Paulista (UNIP) em 2002, conclui-se que Santa Rosa ainda possui, nos dias atuais, uma Festa do Divino ${ }^{30}$, Quermesse de Santo Antônio, Terço de Santo Antônio $^{31}$, Folia de Reis, entre outros.

A Folia de Reis é um exemplo deste processo simultâneo de transformação e permanência. Depois de quase acabar na década de 1980, a prefeitura oficializou o evento em 1985, inserindo-o na agenda cultural do município, o que garantiu sua continuidade. Atualmente realizada no Bosque Municipal, a festa de Folia de Reis conseguiu reunir cerca de dez mil pessoas nos três dias de festas de 2007, garantindo o seu sucesso segundo o relatório de atividades da Fundação Cultural (SANTA ROSA DE VITERBO, 2008). Contudo, a relevância para a vida da comunidade ficou menor. Segundo Boniperti,

Todo mundo que você conversa, que viveu essa época (da Folia de Reis na Amália), lembra com muita saudade. Esse encontro que se faz não chega aos pés. É muito maior agora em quantidade de pessoas envolvidas, mas não chega a comover como era, essa história de ir para um sítio, tal, não tem nem comparação.

Uma crítica possível à institucionalização ou retomada de práticas culturais na cidade é a de que se pretende reinventar tradições, manifestações que já não apresentam a mesma significação do passado, mas que pela repetição e divulgação conseguiriam forjar uma identidade local (HOBSBAWN; RANGER, 2008). Para nós, a resposta está nos próprios relatos dos entrevistados, que reconhecem as diferenças entre os eventos realizados anteriormente e agora, mas que ao mesmo tempo não negam sua importância para a cidade

\footnotetext{
${ }^{30}$ Igual à Folia dos Reis, mas sem o uso de acordeon. Realizada no Clube dos Santos Reis desde 1995.

${ }^{31}$ A Quermesse e o Terço de Santo Antônio são eventos realizados pela Igreja Santo Antônio em Santa Rosa, sob a administração do padre local.
} 
atual. Como diz Gonçalves (2007, p. 29), se patrimônios podem ser inventados, eles também nos "inventam", participam de nossa imagem de cidade e da constituição da subjetividade.

Com o crescimento da cidade a partir da década de 1960, construções do núcleo antigo foram reformadas e/ ou reutilizadas e eventos foram criados para atender os novos anseios da população. A Avenida Presidente Vargas foi asfaltada e se consolidou como a principal entrada de Santa Rosa, sendo ainda hoje local de encontros, ponto comercial e de eventos oficiais e não-oficiais. Em 1966, a nova sede do Grêmio Recreativo foi inaugurada. Em 1970, estudantes da cidade criaram a SUSA - Semana Universitária Santa-rosense - com festas e competições para o mês de julho, período de férias dos estudantes, apesar da cidade não contar com nenhuma universidade. Em 1980, foi inaugurado o clube de campo, Primavera Country Clube. Em 1981, outra manifestação cultural é iniciada, a Caça ao tesouro do Momo, que consiste em encontrar uma peça de madeira enterrada em algum lugar da cidade para receber em troca uma quantia em dinheiro. Segundo os criadores do evento, Renato Alberto Antunes e Ivan Alvim de Freitas, a ideia se baseou no conto O Escaravelho de Ouro, de Edgar Allan $\mathrm{Poe}^{32}$. No ano de 2009, o evento local ofereceu R\$1.500 para quem encontrasse o "tesouro".

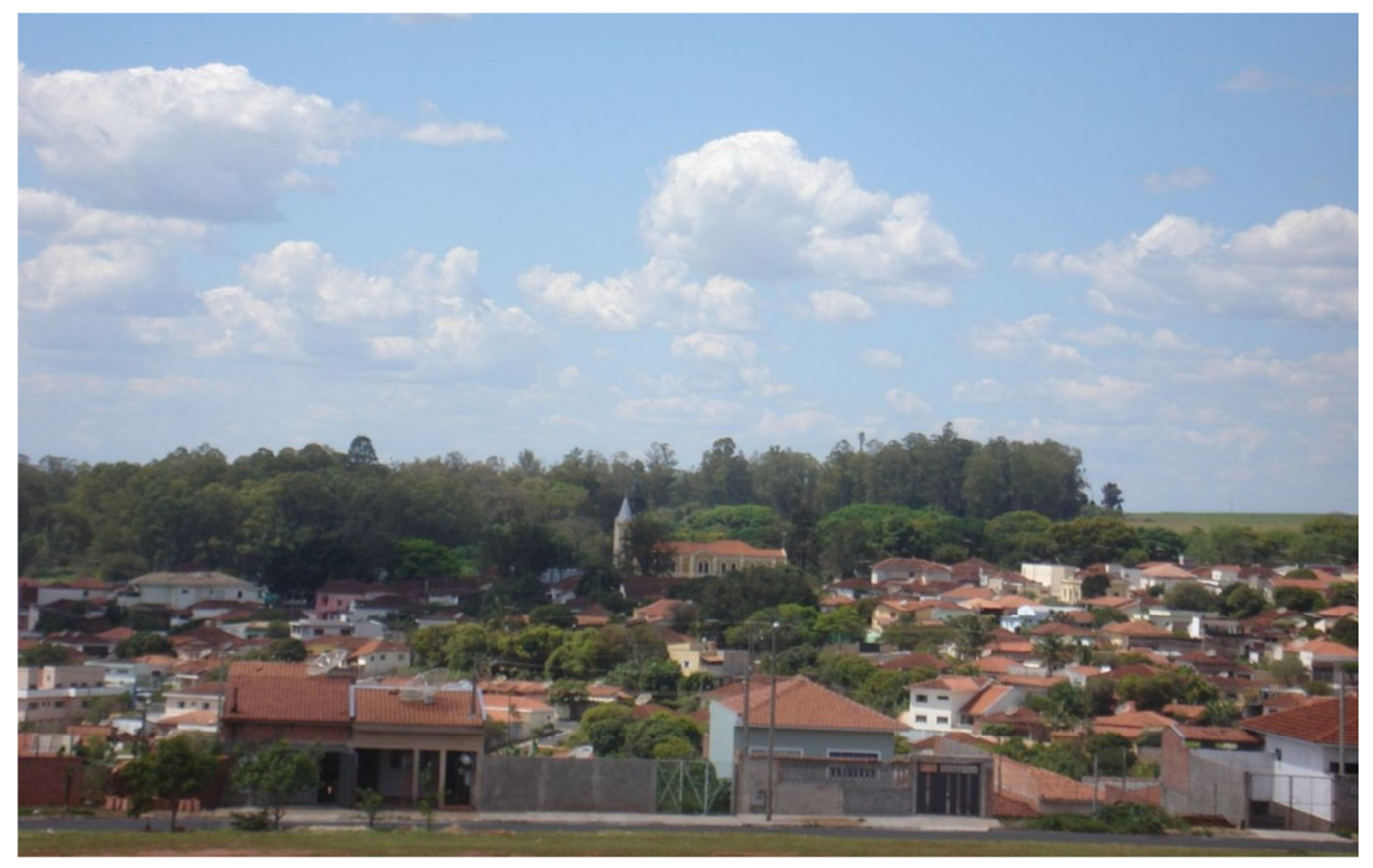

Fig. 4: Panorama parcial da cidade com a Igreja Matriz ao centro

\footnotetext{
${ }^{32} \mathrm{O}$ conto apresenta a história de William Legrand, um cavalheiro que, após perder sua fortuna, passa a residir, junto com um antigo escravo, Júpiter, na ilha de Sullivan, na Carolina do Sul. Após encontrar um escaravelho e um pergaminho com um enigma, William começa a decifrá-lo até encontrar uma grande caixa de madeira enterrada na ilha contendo um tesouro de pirata. Deste modo, o herói volta a ser rico e recupera a confiança de seus amigos, que não acreditavam na veracidade de suas suposições (POE, 1978).
} 
Neste período, o que mais se desenvolveu na cidade foi uma banda de música, presente na Fazenda Amália desde os primeiros anos do século XX, quando Guido Maestrello dirigia um conjunto chamado "Dumont". Em 1985, com a restauração da antiga estação de trem da Cia. Mogiana na cidade, criou-se a Estação da Cultura, com espaço físico e instrumentos necessários para o desenvolvimento do projeto (FUNDAÇÃO CULTURAL DE SANTA ROSA DE VITERBO, c2008).

Boniperti: Todos que eu conheci que ficaram lá, participando intensamente das atividades da banda, todos eles, independentemente da origem sócio-econômica, foram para universidades públicas, fizeram cursos que gostariam de fazer e hoje estão relativamente bem estabelecidos. Daria para citar duas dezenas de pessoas com as quais aconteceu isso. (...) Eu acho que eu nunca conheci uma cidade que tivesse uma relação tão grande com a música, tirando Tatuí, porque São Paulo, obviamente, o melhor está lá. (...) são mais de quinhentas crianças e jovens, adultos, enfim, que estudam música gratuitamente, seja na Estação da Cultura, seja no projeto Guri, tem diversos grupos musicais.

Suzana: A Banda Sinfônica agora vai ter um crescimento exponencial, questão de território mesmo nacional, porque vão gravar um DVD com o Guilherme Arantes, e o projeto é grandioso, tem previsão de vir outros artistas de renome para fazerem também essa gravação com a banda. E temos a fanfarra, que com o maestro Pedro também é maravilhosa...

Daniela: (É) muito falado da Fundação da Cultura, que tem a banda, que é super famosa, muito reconhecida, o maestro. Todos que participam falam muito bem dali.

Romeu: (...) a música é o charme da cidade. (...) a banda é o orgulho, uma banda de nível excelente, feita por estudantes amadores e que toca muito bem. (...) tem quatrocentas pessoas estudando lá, bota mais duas pessoas por família, você tem mil pessoas aí envolvida. No mínimo a família vai ver a banda e isso é muito bom, multiplica. A música hoje já é tratada com muito respeito aqui em Santa Rosa, isso tudo de famílias pobres. Isso é interessante, é didático demais, a existência dessa escola de música gratuita aí...

A banda alcançou o reconhecimento e atualmente está presente no programa de divulgação da cidade. Seja no cartaz na entrada de Santa Rosa, como em outros folhetos, encontramos a figura de um maestro regendo as águas do Rio Pardo com a frase: Santa Rosa de Viterbo: sinfonia do Rio Pardo. 


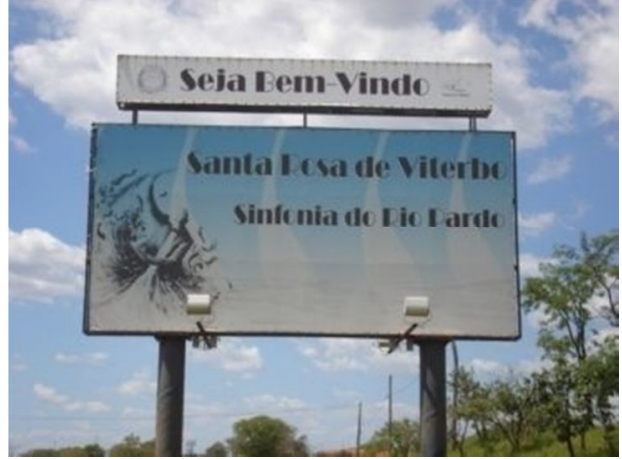

Fig. 5: Cartaz na entrada da cidade

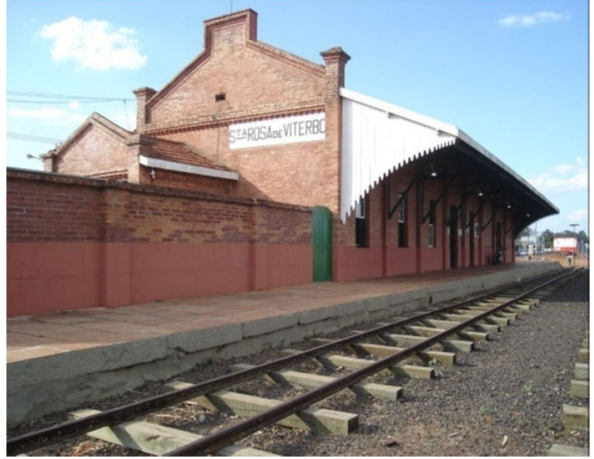

Fig. 6: Estação da Cultura

$\mathrm{Na}$ área econômica, enquanto as indústrias Matarazzo passavam por dificuldades, o comércio se desenvolveu. Segundo a Fundação SEADE, no ano de 2006, o setor de serviços já correspondia a 32\% do Produto Interno Bruto (PIB) da cidade (SÃO PAULO, 2009). Além disso, a abertura de supermercados no ano das entrevistas chamou a atenção dos participantes da pesquisa:

Romeu: (...) a concorrência no comércio é terrível. Você vê, nesse momento, abriram dois supermercados "super super". Como é que sobrevive isso?, (...) pujança, massa salarial. (...) o comércio aqui se desenvolveu justamente por causa desse polo industrial que existe até hoje. O Matarazzo foi embora, praticamente, mas outros grupos vieram e aperfeiçoaram. Isso gera uma massa salarial que permite o desenvolvimento do comércio, desenvolvimento urbano de toda espécie.

Suzana: Minha mãe já teve um comércio e eu lembro das conversas que eu tinha com os vendedores. Eles gostavam muito de Santa Rosa, porque tem muito comércio, por mais que seja uma cidade pequena.

Daniela: Você vê quantos mercados já abriram? Uma coisa que toda mulher precisa hoje. (...) o comércio já ficou muito famoso, principalmente nas cidades da região. Vem muita gente aqui fazer compras.

No entanto, a necessidade de formação e qualificação profissional faz com que todos os dias vários ônibus viajem para Ribeirão Preto levando estudantes e empregados. Ao contrário do período em que os habitantes se inseriam nas oportunidades oferecidas pela fazenda, agora se observa a busca por melhores salários e cargos, muita deles não existentes em Santa Rosa e na maioria das cidades pequenas. De certa forma, mas em proporção menor, o que acontece na cidade é semelhante ao êxodo rural iniciado na década de 1960. Não encontrando faculdades e empregos, parte dos jovens começou a procurá-los na região, e 
quando se estabelecem, muitos deles preferem não voltar mais. A falta de trabalho e suas consequências parecem ter se tornado a principal reclamação dos moradores em relação à cidade. Deste modo, ao mesmo tempo em que percebem o comércio como uma das principais fontes de renda e importante para a cidade, parte deles, principalmente os jovens, anseiam uma melhor qualificação profissional e retorno financeiro. Portanto, ao elogiar e criticar Santa Rosa simultaneamente, os relatos dos habitantes não se configuram como uma contradição, mas reafirmam seu crescimento e transformação econômica, que, contudo, também pode ser um problema, se os analisarmos em relação às aspirações de parte da população.

Daniela: Eu sempre falo que a gente tem a intenção de mudar daqui o ano que vem e
ir pra Ribeirão. Só que às vezes eu fico pensando assim: “- - Nossa, Santa Rosa é tão
gostoso, uma cidade tão legal”. (...) Como toda cidade pequena tem esse problema
(de emprego), questão de ser escasso. Em minha opinião, se eu vejo uma cidade
maior, maior oportunidade de arrumar emprego. Porque aqui, às vezes, tem aquela
questão de ter, vamos supor, duas vagas, então já preencheu aqui, e pra você arrumar
uma vaga, só quando a pessoa aposentar ou quando ela sair pra algum lugar... Então
eu vejo só esse probleminha, que eu acho que é tão mínimo que hoje você pode
tanto trabalhar em Ribeirão e morar em Santa Rosa.

Boniperti: Há uma limitação de ganho em Santa Rosa, isso é evidente. Decidiu ficar em Santa Rosa, então seu poder aquisitivo vai ser limitado. Não é como São Paulo que o céu é o limite, se você abrir uma firma de persianas pode virar milionário. Em Santa Rosa, se você abrir uma firma de persianas, você vai atender, quando muito, cinquenta, cem clientes. É muito diferente. As pessoas que olham desse ponto de vista obviamente querem sair de Santa Rosa.

Paula: Ultimamente tem muita gente que reclama que a cidade, economicamente, não está se desenvolvendo. Fechou a (fábrica de) Sabonete, que muita gente perdeu o emprego. (Tem outras) que também dispensaram um monte de funcionários. A minha avó tem uma loja, então ela fala que nessa parte de comércio está muito fraco, porque o pessoal não tem mais dinheiro pra consumir. Nesses últimos anos tem baixado muito, muita gente vai embora da cidade. Muita gente que se forma não fica aqui, vai embora, vai trabalhar em outro lugar. A maioria das pessoas, os meus amigos, por exemplo, que se formaram, tem eu e mais alguns, mas a maioria mora, mesmo que não muito longe daqui, mora em cidade ao redor, que oferece uma maior oportunidade de emprego.

Assim, cada vez mais, a cidade então isolada em torno da fazenda precisa se relacionar com as localidades vizinhas. Desta forma, o aspecto econômico também tem influenciado no interesse cultural, pois enquanto os mais velhos veem a cidade como um lugar calmo e aconchegante para se viver, jovens preferem Ribeirão Preto, o centro mais próximo, com mais e melhores oportunidades de lazer, emprego, compras, entre outros. 
Cheyenne: Eu só vejo criticarem mesmo. Eu vejo os meus alunos, todo mundo fala, “ - Ah, não tem muita coisa pra fazer, não tem muito lugar pra ir”. Eu estou falando da idade adolescente, jovens. Eles estão entediados daqui, é a impressão que eu tenho, que não tem muito lugar pra ir, que são sempre as mesmas coisas, as mesmas pessoas.

Boniperti: Santa Rosa é muito limitada (...). (...) Por exemplo, (existe) um grupo muito grande que gosta de ir a Ribeirão Preto, que é o centro mais próximo. Esse pessoal vai a Ribeirão pra quê? Para shopping, pra loja, para bares e restaurantes movimentados, baladas, é isso que o pessoal gosta de lá, e esse é o grupo mais jovem. Aí tem um grupo intermediário, um pouco mais velho que já busca emprego, boas colocações.

Daniela: Santa Rosa é uma cidade ótima pra morar, eu só vou mudar daqui mesmo pela questão do emprego. Eu fico imaginando: “ - Ribeirão tem mais oportunidades".

Suzana: (...) as pessoas gostam de Santa Rosa, os mais jovens não seriam tanto, pela questão que não tem uma faculdade estruturada, porque tem a distância, algumas particulares, mas tem poucos cursos, de repente são os mais procurados, tipo administração e tal, mas poderia talvez ter uma faculdade maior, mesmo que seja particular. (...) Defeito aqui eu acredito que seja o emprego ainda, tem muitas pessoas desempregadas. Lá no meu trabalho eu vejo muitas pessoas que vão procurar fazer currículo, cadastro em sites pra procura de emprego.

O que se destaca é a relação economia e cultura, porque, em busca de emprego e estudo, este novo grupo começou a desfrutar o que uma cidade de médio porte oferece e não está presente em uma pequena cidade do interior: shoppings, boates, teatros, entre outros; uma situação diferente do período anterior, pois enquanto a população apresentava outro modo de vida, a fazenda atendia as suas necessidades. Isolada do contato com outros centros urbanos além de Santa Rosa, os habitantes se adequavam ao modelo de vida vigente, e mesmo com pouco estudo encontravam emprego nas indústrias Matarazzo. Como vimos, a fazenda era considerada uma verdadeira cidade.

Com a expulsão dos moradores das colônias, os santa-rosenses precisaram encontrar novas formas de sustento e uma melhor educação tornou-se um diferencial. Com mais pessoas estudando, o desejo de encontrar um emprego melhor e mais rentável mostrou que a cidade era limitada na qualidade e diversidade de vagas, apesar de uma boa parte ter obtido sucesso na área de serviços. Nesta nova conjuntura, a cidade ficou pequena.

Isto também não significa que a vida na fazenda era melhor. Na cidade, os moradores encontraram novas oportunidades de crescimento pessoal e profissional, e exatamente pela gama de alternativas, de escolhas que a cidade oferece, a vida se tornou mais complexa. As tradições também não acabaram, mas diante de uma nova realidade estão se transformando. Como afirma Sahlins (1997a, p 58), ao estudar a cultura em povos isolados e interligados, 
“integração e diferenciação são co-evolucionárias”. O que se observa é uma possibilidade de interculturalidade, como proposto por García Canclini (2007, p. 17), ou seja, o entrelaçamento, a confrontação e negociação em uma cultura que apresenta elementos híbridos, no caso, caipiras e urbanos simultaneamente.

Além do mais, conhecer o que Ribeirão e outras cidades oferecem ao mesmo tempo em que estão mais distantes dos costumes antigos também pode permitir uma maior reflexão destas práticas em Santa Rosa, produzindo uma geração mais consciente de sua cultura.

\footnotetext{
Os costumes tornam-se conscientes, quando mais não seja, por causa da própria possibilidade de sua violação - inclusive aquela ocasionada pelo exemplo de costumes contrastantes vigentes em povos vizinhos -, o que notadamente exige que eles sejam inculcados nos jovens, juntamente com os sentimentos morais e emocionais apropriados. Obrigada assim a encontrar explicações racionais para práticas cujas razões são desconhecidas, a consciência da cultura não é uma mera racionalização, mas uma quase tradição consistente com os saberes, narrativas e interesses da sociedade (SAHLINS, 1997b, p. 135).
}

Desta forma, abandonamos a ideia de perda, "extinção", como diz Sahlins, para compreendermos o surgimento e/ ou transformação de práticas culturais no espaço urbano.

Por meio deste relato, observamos que, assim como nas grandes metrópoles, algumas pequenas cidades do interior também passaram por significativas transformações econômicas e sociais nos últimos anos, mesmo quando não estavam vivendo uma explosão demográfica. Deste modo, superamos a visão estigmatizada de cidadezinhas estacionadas no tempo, com pessoas sem estudo e mal qualificadas, e muito menos contribuímos para uma visão romântica, como muitas vezes sugeriu a literatura.

Ainda neste caso específico, verificamos que o êxodo rural ocorrido entre as décadas de 60 a 80 do século XX transformou definitivamente a cidade, obrigando a diversificação dos postos de trabalho e permitindo o surgimento, desaparecimento e hibridização de práticas culturais.

Eventos com a Folia de Reis e lugares como a Fazenda Amália nos permitem mapear parte do patrimônio cultural material e imaterial da cidade, referências para a memória e identidade da população atual. Através destes bens, somos incentivados a refletir sobre os valores que os moradores atribuíram a estas manifestações e lembranças, como se adaptaram ao novo ambiente da cidade e suas perspectivas futuras. 
Em outro ponto de vista, a necessidade de circulação espacial devido, principalmente, às condições econômicas permitirá a constituição de novas relações entre grupos e lugares, exigindo novas reflexões sobre a economia e a cultura no passado, presente e futuro de Santa Rosa de Viterbo, igual e ao mesmo tempo tão diferente de diversas outras cidadezinhas espalhadas pelo Brasil.

No entanto, a maior contribuição da análise deste quadro parece ser a possibilidade de questionar uma ideia evolutiva de cidade. No caso de Santa Rosa, poder-se-ia pensar, a princípio, que a fazenda precisou se transferir para uma pequena cidade e agora Santa Rosa deveria tornar-se maior para atender uma nova situação, garantindo maiores oportunidades e satisfação por parte dos seus moradores. O que na realidade observamos é que o crescimento da cidade também exige um novo modo de vida, que reclama por outras necessidades. A vida das pessoas na cidade não é necessariamente melhor apenas pelo oferecimento de mais serviços, diversidade de empregos, moradias, etc., pois as condições desta vida também modificam, como a exigência de uma melhor qualificação profissional.

Além do mais, este panorama reforça a dificuldade para definir o que é uma cidade. A fazenda possuía indústrias, comércio, agricultura e mais moradias e moradores que a zona urbana, o que, no senso comum, seriam características que definem uma cidade, apesar da fazenda ser uma propriedade particular, sem apresentar condições políticas e administrativas para ser classificada desta maneira. Como aponta Weber (1999, p. 415), características que geralmente atribuímos apenas às cidades também se encontram em aldeias, como bens de raiz próprios e economia de receita e despesas. O que a diferencia de cidade, neste caso, é a sua condição política. Os moradores antes de serem cidadãos eram empregados. É claro que enquanto viviam na fazenda estes moradores também eram santa-rosenses, detinham o direito a voto e as garantias constitucionais da época. Entretanto, como vimos, o poder de influência da fazenda na cidade era muito grande, e como funcionários e dependentes da moradia e emprego, os interesses dos patrões muitas vezes se sobrepunham a execução destes direitos.

Por fim, caracterizar as circunstâncias socioeconômicas de uma cidade do porte de Santa Rosa de Viterbo possibilita estabelecer relações com cidades semelhantes, produzindo novos diálogos sobre o interior, principalmente paulista ${ }^{33}$. Deste modo, enquanto

\footnotetext{
33 Um exemplo que podemos citar é o trabalho de Magnani (2007) em Santana do Parnaíba, uma cidade aparentemente muito diferente de Santa Rosa por se localizar na região metropolitana da cidade de São Paulo e possuir mais de quatrocentos anos, sendo uma cidade histórica. Realizado no ano de 1984, quando a cidade tinha 15.995 habitantes, o autor observou a divisão do espaço urbano em dois núcleos, um bairro central constituído por antigos moradores e um novo formado por aqueles que tinham chegado à cidade há pouco tempo, como em Santa Rosa na construção de casas na Fazenda Amália e na zona urbana. Também é sublinhada a importância de festas como espaços de sociabilidade, e os moradores valorizavam a cidade, entre outros motivos, pelo seu
} 
contribuímos para a história de cidades que muitas vezes sequer possuem um arquivo público, como Santa Rosa, inserimos mais uma peça no mosaico que justifica a história local e regional ao ressaltar as diferenças e similaridades entre lugares específicos.

aspecto tranquilo, como indicamos na cidade objeto deste estudo. Assim como em Santa Rosa, verificou-se na época que os jovens também reclamavam das opções de lazer, trabalho e consumo na cidade, procurando nas próximas Osasco e São Paulo o que desejavam, entre outros paralelos que permitem aproximações entre as duas localidades. 


\subsection{A CIDADE E SEUS SÍMBOLOS: A FORMAÇÃO DE PATRIMÔNIOS CULTURAIS EM SANTA ROSA DE VITERBO}

Como vimos no Capítulo 2, a criação do Centro Nacional de Referência Cultural (CNRC) em 1975 e a presidência do IPHAN por Aloísio Magalhães entre 1979 e 1982 foi fundamental para reformular e ampliar a noção de patrimônio no Brasil. Enquanto no período anterior o patrimônio era reconhecido majoritariamente pelos seus valores históricos e artísticos, o que privilegiou a preservação de determinados bens, a partir desse momento acrescentou-se o valor cultural, mais abrangente que as adjetivações anteriores, permitindo também a valorização de diversas práticas populares, como o artesanato, danças e pratos típicos regionais.

De modo geral, esta transformação reflete os diferentes usos da ideia de cultura pelas instituições do setor. Antes da criação do CNRC e a presidência de Aloísio Magalhães, as obras tombadas se referiam principalmente à cultura erudita e dominante, a atividades artísticas e intelectuais tradicionais praticadas por apenas uma parcela da população. Com as discussões das décadas de 1970-80, a noção de cultura assumiu uma perspectiva mais antropológica, de "modo de vida global", e ao contrário de tentar identificar uma cultura nacional, os trabalhos se dirigiram para a valorização da nossa diversidade e heterogeneidade.

Como observa Chartier (2009, p. 34), esta dualidade do conceito de cultura pode ser esquematicamente dividida em duas linhas de significado:

a que designa as obras e os gestos que, em uma sociedade dada, se subtraem às urgências do cotidiano e se submetem a um juízo estético ou intelectual e a que aponta as práticas comuns através das quais uma sociedade ou um indivíduo vivem e refletem sobre sua relação com o mundo, com os outros ou com eles mesmos.

O risco, para DaMatta, é que a visão de cultura como um conjunto de atividades artísticas e intelectuais permite que ela seja usada como sinônimo de "sofisticação, de sabedoria, de educação no sentido restrito do termo" (DAMATTA, 1981, p.1), alimentando a perspectiva de que algumas pessoas têm cultura e outras não, de que algumas sociedades são avançadas e outras atrasadas. Neste sentido, a palavra cultura é utilizada para classificar e 
hierarquizar pessoas, grupos sociais e nações, tornando-se um instrumento de discriminação e exclusão.

Recorrendo aos referenciais teóricos da Antropologia e Sociologia, o autor defende a concepção inclusiva, na qual todos os homens, sociedades e países possuem cultura, e que, apesar de singulares, não se encontram em diferentes estágios de desenvolvimento. De forma sucinta, cultura seria "um código através do qual as pessoas de um dado grupo pensam, classificam, estudam e modificam o mundo e a si mesmas" (DAMATTA, 1981, p.2).

Já para García Canclini (2007, p.41), a clássica definição antropológica de cultura como a "totalidade da vida social" apenas separa a cultura da natureza e não da sociedade, tornando-a um conceito muito amplo, que engloba quase tudo. Assim, o autor sugere uma definição mais operacional e restrita, de cultura como os "processos sociais de produção, circulação e consumo da significação na vida social" (GARCÍA CANCLINI, 2007, p. 45). Neste aspecto, sua visão se aproxima do conceito de Geertz (2008), que pensa a cultura a partir de uma interpretação semiótica. Para este último, a cultura pode ser definida como

um sistema de concepções herdadas expressas em formas simbólicas por meio das quais os homens comunicam, perpetuam e desenvolvem seu conhecimento e suas atividades em relação à vida (GEERTZ, 2008, p. 66).

De qualquer modo, Williams (2007, p. 121) reconhece que a noção mais difundida de cultura é a de "música, literatura, pintura, escultura, teatro e cinema", sendo inclusive a perspectiva adotada pelos Ministérios da Cultura. No entanto, ao contrário de uma posição pessimista, o autor acredita que todo o movimento de vê-la como um sistema de significações gerais também ampliou a noção de "atividades artísticas e intelectuais", diminuindo a oposição entre as duas concepções aqui tratadas. Ela não seria apenas as

artes e formas de produção intelectual tradicionais, mas também todas as 'práticas significativas' - desde a linguagem, passando pela arte e filosofia, até o jornalismo, moda e publicidade - que agora constituem esse campo complexo e necessariamente extenso (WILLIAMS, 2008, p 13) ${ }^{34}$.

\footnotetext{
${ }^{34}$ Williams (2007, p.121) ainda analisa mais duas concepções de cultura, no qual o segundo significado pode ser considerado um dos resultados do contato com atividades artísticas e intelectuais: 1) Cultura como cultivo da terra, processo físico, permitindo, posteriormente, a idéia de cultivo da mente, tornando-se culto e 2) Cultura como desenvolvimento intelectual, espiritual e estético.
} 
Porém, se a sociedade não vê a cultura como uma "maneira de viver total", como diz DaMatta, mas como um conjunto determinado de atividades, ao contrário do que defende García Canclini, o que é entendido por patrimônio quando adjetivado de cultural? Como a noção de cultura influencia na leitura e valorização de patrimônios?

Não pretendemos produzir uma discussão que enalteça uma definição de cultura, mas mostrar algumas consequências dos seus diferentes usos, como sugere Gonçalves (2007, p. 244). Ao considerarmos que os patrimônios são discursivamente constituídos, entre os nossos objetivos está o de analisar esses discursos para compreender a classificação, pelos moradores, de determinados bens como patrimônios culturais (GONÇALVES, 2007, p. 142), que no escopo deste capítulo são a Banda Sinfônica de Santa Rosa de Viterbo, a Semana Universitária Santa-rosense, a Fazenda Amália e a Folia de Reis.

Em nossas entrevistas, encontramos diferentes concepções de cultura. Em alguns casos, aproximam-se da ideia de cultura como modo de vida, pois consideram as diversas formas de expressão do social, suas manifestações:

Romeu: (Cultura) é a soma dos conhecimentos das comunidades, dos povos. Eu penso que são todas as manifestações, verbalizações, gestuais e orais. Está na música, está no teatro, está na dança. E a cultura é coisa que se conta também; a tradição oral, a mentira, a fofoca, o folclore. Eu penso nisso tudo e um pouco mais.

Cheyenne: Eu penso em aprendizado de coisas diferentes, em pessoas de tradições diferentes, em costumes diferentes, eu penso nisso, conhecimento sobre outras maneiras de viver, ver uma situação.

Entretanto, a visão dominante é a de "atividades artísticas e intelectuais" e seus produtos, que além de conhecimento/ tornar-se culto, permitiria a inclusão social e, consequentemente, uma melhor qualidade de vida:

Paula: (Cultura são) Livros, teatros, oficinas de aprendizado. Tem aquelas oficinas que eles fazem com os jovens para inserir. Esse tipo de coisa.

Daniela: É uma coisa que eu acho que é essencial: tem que ter cultura hoje. Às vezes a gente ouve falar: "uma pessoa que tem cultura". O que seria uma pessoa sem cultura? A pessoa que não teve uma oportunidade, vamos supor, de estudar, de frequentar um bom lugar, um teatro. Às vezes não sabem nem o que é um teatro, uma peça de teatro, um sarau... Então eu acho que é uma coisa que todo mundo deveria ter, que, infelizmente, muitos não tem, um diferencial na vida. 
Mateus: Acho que a cultura é um polimento e depende de cada um. Você pode ser muito rico e não ter cultura nenhuma. Você pode ser uma pessoa extremamente pobre e ser uma pessoa que tenha uma cultura, embora limitada, mas você pode ser um grande artista, num dado foco. A cultura é de cada um, mas ela precisa de muito mais incentivo. Então eu acho que cultura está muito aquém, falta muito, a gente está longe de ser pessoas realmente muito cultas e ser um país que incentiva a cultura, que produz cultura. A gente praticamente não produz cultura.

\subsubsection{A Banda Sinfônica}

Nesta perspectiva, a Banda Sinfônica de Santa Rosa de Viterbo incorpora o que a maior parte dos moradores entende por cultura, tornando-se um símbolo reconhecido e valorizado na cidade. A música sempre esteve presente na vida dos santa-rosenses, quando, no começo do século XX, alguns habitantes criaram a Banda Dumont e, posteriormente, a Banda Giuseppe Verdi, ambas já extintas. Dando continuidade a esta suposta tradição, em 1985, inaugurou-se a Estação da Cultura, originalmente a estação do ramal ferroviário desativado do município, com o objetivo principal de formar uma nova banda sinfônica sob a direção do maestro Maurílio de Oliveira Júnior. Neste caso, com apoio político, a banda se institucionalizou e, atualmente, é a Sinfônica de Santa Rosa de Viterbo.

Suzana: Uma pessoa sem cultura é, nos seus vários sentidos, uma pessoa que praticamente não vive. A cultura faz parte do nosso dia-a-dia, é através dela que a gente se reconhece, é através dela que a gente vive, então é essencial! A pessoa que difunde sua cultura, que reconhece e que sabe valorizar, é mais fácil de ser reconhecida perante o global. E para Santa Rosa, está em crescimento e para melhor, porque quando fala Santa Rosa de Viterbo, todo mundo diz " - Ah, é a cidade que tem a Banda Sinfônica”, porque ela é reconhecida em toda a região. É um exemplo assim forte, porque é mais atuante, mas poderia ser reconhecida pelo teatro também, basta o incentivo. 


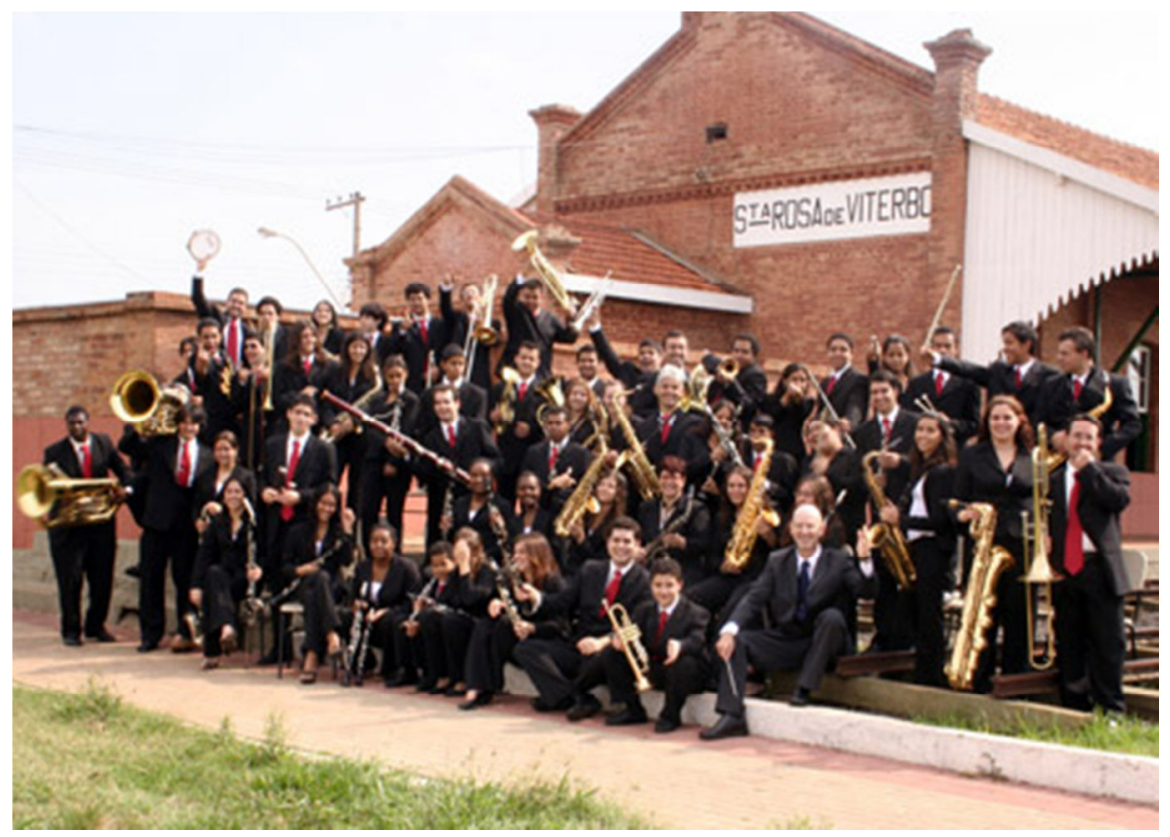

Fig. 7: Banda Sinfônica de Santa Rosa de Viterbo

Por materializar a noção de cultura, ela dificilmente surge como ponto de conflito ou é questionada em sua importância. Primeiro, porque, na conjuntura de Santa Rosa, sem teatro, museu e demais instituições culturais, uma banda sinfônica é o que mais se aproxima de uma ideia de "alta" cultura, favorecendo a opinião de que ela deve ser apreciada como demonstração de bom gosto e distinção. Até mesmo uma pessoa que nunca ouviu a banda e não conhece seus projetos é capaz de referenciá-la como uma iniciativa positiva a partir da concepção de que uma banda sinfônica, assim como uma exposição de obras de arte ou a leitura de um livro, permite "adquirir" cultura. Segundo, porque ao caracterizá-la como a "sinfonia do Rio Pardo", em referência ao rio que atravessa o município, conforme divulgado pela administração local em veículos publicitários (pôsteres, outdoors), ela não é apresentada apenas como uma banda de música, mas como um símbolo santa-rosense, única pela sua localização. Deste modo, uma crítica à banda é também à cidade, que nesta definição tornamse indissociáveis.

Valter: Não posso deixar de ressaltar que temos em nossa cidade a Banda Sinfônica, que atualmente é destaque e realiza apresentações em várias cidades da região. Isso me deixa extremamente orgulhoso.

André: Nós temos uma banda fantástica que é uma referência nacional. A banda de Santa Rosa é uma das três melhores do Brasil. Gravou um DVD agora. (...) A banda não tem preço. Santa Rosa hoje tem uma escola de música que vem de vinte anos. Todos os prefeitos merecem parabéns. Não só quem criou, mas os que mantiveram funcionando no mesmo nível. Santa Rosa tem seiscentos alunos de música. Tem três 
bandas: a banda filarmônica, a juvenil e a iniciante. E tem mais uma garotada que está aprendendo música, que vai se renovando. Da primeira turma, da qual eu também fiz parte, tem pessoas que vivem da música. Tem o Rubinho Antunes, o Douglas, baterista, e mais um monte de gente, fruto de um trabalho de vinte anos atrás.

Ao vincular a banda ao Rio Pardo, reforça-se a concepção de que a música é uma aptidão natural dos santa-rosenses, observável desde a fundação da cidade. Como bandas já existiam no período em que os imigrantes trabalhavam na Fazenda Amália, no caso as Bandas Dumont e Giuseppe Verdi, a Sinfônica de Santa Rosa adquiriu o status de tradição, que pela repetição e continuidade em relação ao passado (HOBSBAWN, RANGER, 2008, p.9), tornase "historicamente coerente" (GONÇALVES, 2002, p. 116).

Maurílio: Em cidade pequena, as opções de cultura, de aprendizado de arte, são muito poucas. Na grande maioria das cidades do interior, a única opção de aprendizado de música acaba sendo a escolinha da banda; não existe outra opção. Aqui em Santa Rosa, nós instituímos isso, criou-se um espaço, uma metodologia, as bandas de acesso, então aí abriu espaço para as pessoas. O fato de ser gratuito também possibilita em um país em que as pessoas lutam pra sobreviver. Às vezes, não sobra recurso pra investir em cultura, no aprendizado extracurricular e aí, aproveitando esse vazio, e a tradição que existe também de bandas no país, que, no caso de Santa Rosa, até antes da cidade existir, quando Santa Rosa era ainda um povoado, já tinha banda. Com trezentas, quatrocentas pessoas que moravam aqui no povoado, já existia um coreto de madeira ao lado da igrejinha; tem documentos que provam isso. A gente dá sequência a uma tradição e não deixou ela extinguir. As pessoas sentem necessidade de aprender música. Faz parte da vida das pessoas, não tem como separar. (...) (Se a cidade tivesse um museu, teria) que fazer um resgate da história da cidade, como a cidade se desenvolveu para que ela conheça o seu passado e a partir daí planeje o futuro dentro da sua linha de vida, porque uma cidade que tem tradição de bandas como a nossa, não pode querer mudar para uma área que não existe, que nunca teve experiência. Pode até começar com outros projetos, mas tem que apoiar o que é natural da cidade.

Estela: A nossa colonização foi italiana, espanhola, então é realmente muito rica. Nós temos uma inclinação musical muito forte, tanto que em 1910 já havia registros de banda municipal. Antes já tinham bandas, cinema chegou à capital, aqui também chegou, então essa cultura europeia é muito forte. 


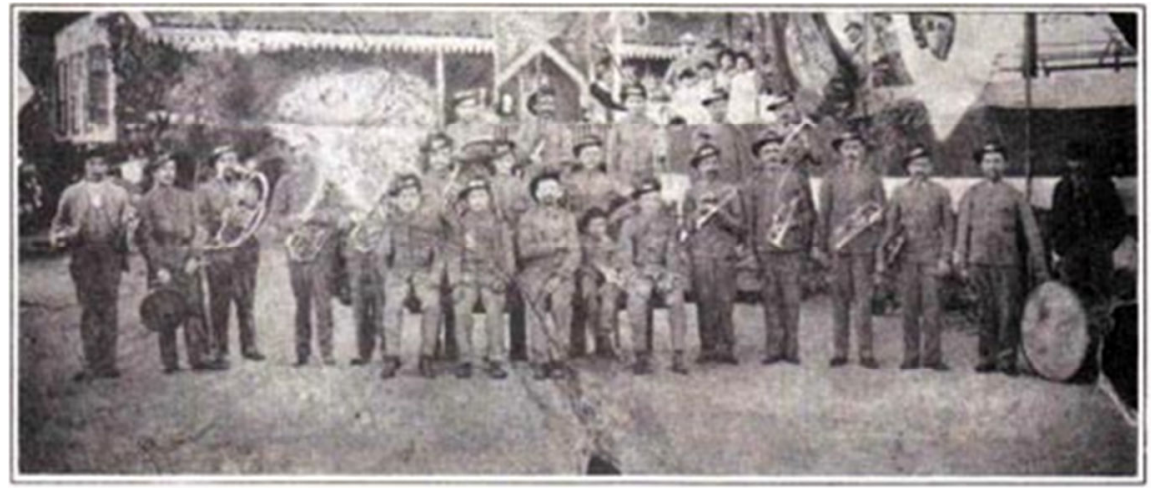

Fig. 8: Banda Dumont em 1901

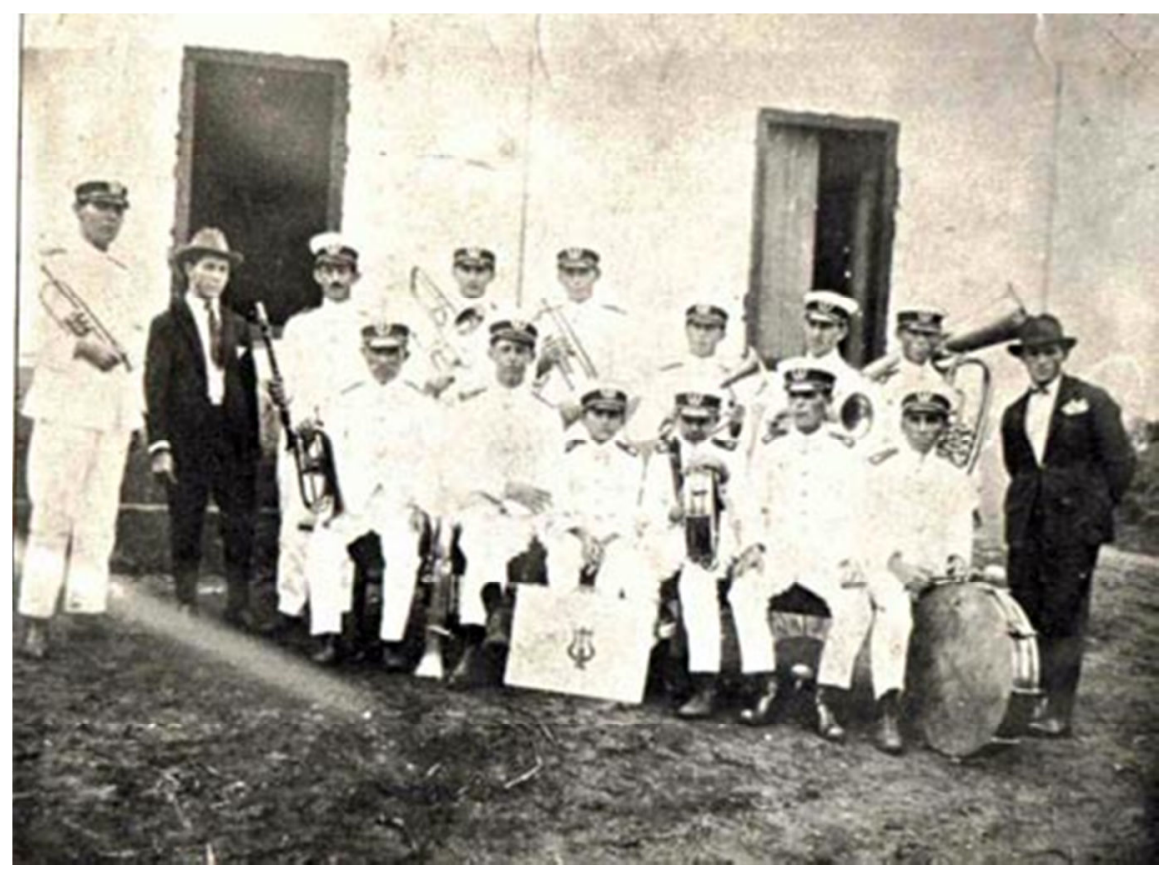

Fig. 9: Banda Giuseppe Verdi em 1926

Nesta condição, quando a antiga estação ferroviária local da Cia. Mogiana se transformou na Estação da Cultura para atender as necessidades da Banda Sinfônica, os discursos sobre a música em Santa Rosa, decididamente, se legitimaram. Com apoio da prefeitura, reconhecimento público e espaço próprio, foi possível desenvolver uma política administrativa e programas sociais independentemente das mudanças de prefeitos e diretores culturais. A banda assumiu o papel de principal bem cultural local, o parâmetro para o desenvolvimento de outras iniciativas, o que fica claro ao verificarmos o papel exercido pelo maestro Maurílio de Oliveira Júnior, que além de dirigir a banda, é um dos principais 
responsáveis por praticamente todos os eventos que a cidade produz, desde o Carnaval de rua ao Encontro de Folia de Reis.

Badra: Eu acho que (a cidade) é ainda pobre em matéria de programas culturais. O
que salva muito é a nossa Estação da Cultura, que foi montada na época do seu
Nagib (ex-prefeito). Essas coisas que foram montadas com base, com muito apoio
político e conseguiu um estágio, um avanço no programa, ficaram depois que o seu
Nagib deixou a prefeitura. (...) Isso é o resultado de um trabalho bem feito que os
prefeitos que vieram não puderam destruir, porque ele tinha uma base muito sólida,
que foi a formação dos alunos, uma banda já bem montada. Quem que ia por a mão?
Você vê que em outros municípios, apesar do empenho do maestro que foi para
tentar montar a banda, não pegou.

Maurílio: A Estação era para ser inicialmente o polo administrador da cultura. Como eu percebi que havia a necessidade de ter um espaço só para a banda, eu fiz um projeto na época junto com o Omar, que era o prefeito, para reformar a cadeia antiga, que estava abandonada, e transferir a sede para lá.

A estabilidade da banda não se restringe somente ao apoio político e valorização social, mas à possibilidade de receber financiamentos privados e governamentais para a sua manutenção. Pela Lei Rouanet e pelos recursos de empresas da região já foram comprados instrumentos musicais, a Estação da Cultura foi reformada e um CD da banda foi gravado (SANTA ROSA DE VITERBO, c2009). Neste momento, a construção de uma imagem que a vincula à cidade e região favorece os investimentos de empresas locais, e o seu projeto social, de oferecer aulas de música para mais de trezentas crianças e jovens, formar professores e fazer apresentações gratuitamente, justifica sua relevância também para o poder público.

Questionada sobre o sucesso da banda em relação a outros projetos na cidade, Suzana aponta os investimentos realizados como uma das explicações:

\footnotetext{
Ela recebe muito patrocínio de empresas privadas. Então, tendo dinheiro, que é uma base importante, acaba sendo mais reconhecida. (...) se (você) vê todo mundo uniformizado, bonito, todos os instrumentos novos, um maestro competente, músicos com vontade de tocar e tal, (ela) acaba sendo reconhecida. Imagina se não tivesse incentivo; acho que não seria tão reconhecida.
}

Possuir um espaço para receber alunos, se preparar e fazer apresentações é um dos aspectos em que a banda mais se sobressai em relação às outras atividades na cidade. Segundo os participantes da pesquisa, uma das principais deficiências de Santa Rosa é não ter espaços 
para o desenvolvimento de atividades culturais, sendo a Estação da Cultura o contraponto, o referencial. Observam, inclusive, atividades emergentes, como a dança, mas reconhecem que elas não se desenvolvem porque não têm condições de se organizarem. Por esses motivos, o próprio maestro da banda, que também está à frente da Fundação Cultural, tem buscado recursos financeiros para a construção de diversos espaços culturais, permitindo apresentações teatrais, musicais, entre outros.

Esta atenção é, provavelmente, o maior benefício de um bem/lugar/construção ser definido, nos discursos e ações oficiais, como uma expressão cultural local, pois mesmo alguns lugares, como a Fazenda Amália, e atividades, como a dança, sendo reconhecidos e estimados pela população, não despertam igual interesse dos governantes e setor privado pela sua preservação e manutenção, devido a não atribuição de valores, no âmbito institucional, que permitem identificá-los como símbolos da cidade, no caso da dança por ser uma iniciativa recente e, da Fazenda Amália, pelo suposto conflito de ser uma propriedade privada.

Omar: Nós precisamos de mais espaços: um teatro, um parque temático, algumas áreas que possam ser usadas para a produção desses bens culturais. Eu acho que estão faltando alguns espaços.

Maurílio: Existem, por exemplo, áreas como a dança, pintura, artesanato, teatro, uma série de atividades culturais que não se desenvolvem porque não tem espaço físico. Nós temos aqui na cidade uma série de pessoas que gostam de dança, mas vai dançar onde? Onde vai implantar esse curso? Não tem lugar. (...) Como vai desenvolver o teatro se não tem o espaço para as pessoas se apresentarem ou mesmo praticarem? Como vai desenvolver a dança se não tem a sala apropriada? Às vezes é necessário o galpão de uma escola, o fundo de uma garagem. O poder público não pode trabalhar assim; ele tem que trabalhar instituído. $\mathrm{O}$ fato de a banda ter um relativo sucesso, um relativo respeito da população é porque eu consegui criar o espaço dela.

Valter: Em relação à dança, posso dizer que temos vários lideres, pessoas que se forem incentivadas e se proporcionarmos condições vão trazer desenvolvimento nessa área. (...) Não adianta falar: “- Ah, tendo uma árvore, debaixo dela eu consigo fazer tudo". Isso é uma filosofia bonita, mas que não é fato.

André: Há 20 anos tinha concurso de blocos carnavalescos, tinha cinco blocos tradicionais com duzentas pessoas cada, tinha Congada, Encontro de Reis, Feira Agrícola, a banda foi criada naquela época. Ganhamos na década de 90 um cinema/ teatro, era o Cine Teatro Paradiso. Posteriormente, sem nenhuma justificativa, foi desativado. Hoje Santa Rosa não tem um espaço para cinema e teatro. Tem que se sujeitar ao Grêmio (Recreativo), por improviso.

Em situação oposta, verifica-se que a banda adquiriu predicados que permitem e explicam sua citação constante e valorização pela população, poder público e setor privado 
santa-rosense. Independentemente do fato de ser ou não uma tradição inventada, do seu sucesso ter sido traçado como natural ou uma aptidão local nata, muitas das representações positivas da cidade fazem referência à banda como símbolo de cultura, entendida como um conjunto de atividades artísticas e intelectuais. Um ponto positivo é que, desta forma, ela consegue manter suas atividades e projetos sociais, garantindo que crianças e jovens recebam uma formação musical, mesmo em períodos de mudanças políticas.

Sustentada pelas ideias de tradição e cultura, a banda tornou-se praticamente um consenso, e questioná-la exigiria revisar o que é considerado a identidade local, manifestação típica: a música. Como aborda Fonseca (2005, p.21), essas políticas patrimoniais, mesmo quando não assumem esse nome, atingem um grau de eficiência simbólica tão alto que raramente ocorrem contestações pela população quanto ao valor de um bem. Deste modo, a partir do momento em que essas representações existem, elas produzem efeitos que não podem ser ignorados somente porque seguiu um percurso imaginado. Aquilo que pode ser chamado de invenção foi o que, na realidade, permitiu que a banda adquirisse todo o reconhecimento hoje existente.

A Banda, assim como qualquer outro patrimônio, é um meio, ideológico e político, pelo qual se dá forma e conteúdo a abstrações como "identidade", "memória" e "nação" (ARANTES, 1984, 8). Portanto, além de referências a períodos e fatos históricos para legitimar um bem como patrimônio cultural, é necessário compreender os valores atribuídos pela sociedade através dos seus usos. Segundo Durham (1984, p. 30-31), "devemos tentar definir o patrimônio em função do significado que possui para a população, reconhecendo que o elemento básico na percepção do significado de um bem cultural reside no uso que dele é feito pela sociedade".

Assim sendo, compreende-se o porquê da banda ser considerada um dos principais patrimônios santa-rosense, pois além de sua já reconhecida relevância para a história e cultura da cidade, também se instituiu como discurso e narrativa, uma alegoria da identidade local e daquilo que a população entende por cultura. Ainda, ter como sede uma estação ferroviária desativada, vista como lugar histórico, fortalece a relação da banda com o próprio desenvolvimento do município, como se seus trilhos ligassem o passado, o presente e o futuro. 


\subsubsection{A Semana Universitária}

Contudo, a Banda Sinfônica poderia ser ainda mais valorizada se seus integrantes e o público também a vissem como uma atividade de lazer ${ }^{35}$, uma ocasião para ouvir música e preencher o tempo livre, e não somente uma oportunidade para "adquirir" e "mostrar" cultura, mesmo que sejam estas as características que autorizam sua visualização como patrimônio cultural. Segundo podemos observar, principalmente entre os jovens, possuir lugares para sair, se divertir e entreter é um dos principais desejos dos santa-rosenses ${ }^{36}$. É comum a reclamação de que a cidade não oferece praticamente nenhuma atividade para preencher o tempo livre e que são obrigados a frequentar sempre os mesmos lugares por falta de opções:

Paula: Não tem muita opção de lazer. A maioria das pessoas jovens acha ruim. (As pessoas falam) que não tem nada para se fazer, que são sempre os mesmos lugares pra sair. É que os únicos lugares que tem pra sair são o (bar) Chiqueirinho, a praça e o Grêmio (Recreativo).

Daniela: (...) Às vezes, o pessoal não tem um lugar pra sair (e diz:) “ - Ah, se tivesse um cinema, seria legal" (...)

Badra: (...) O jovem está sem atividade, por isso que tem muita droga. Reúnem-se nas praças só bebendo, sem rumo, sem objetivo.

Mateus: É muito bom aqui, mas não tem quase nada. Tudo funciona direitinho, mas tem muito pouco. Se você quiser ter um grupinho de pessoas que toque música, fale sobre música, vai ser muito difícil; aqui é tudo muito restrito. Para o básico é ótimo, mas acho que falta muito mais. Para uma cidade de vinte e três mil habitantes é bom, mas poderia ser muito melhor se tivessem pessoas com mais ideias, se as pessoas fossem pra fora e vissem as coisas boas que acontecem e fizessem isso em menor escala aqui, pra muita menos gente, para ganhar muito menos dinheiro, mas fazer, trazer.

Nesta situação, a Semana Universitária Santa-rosense (SUSA) aparece como a capacidade do município em oferecer lazer para os seus habitantes e, como a Banda Sinfônica, um modelo a ser seguido pelas próximas gerações. Desta forma, enquanto a banda,

\footnotetext{
${ }^{35}$ É provável que muitos dos seus integrantes considerem a banda uma atividade de lazer, mas, de modo geral, esta concepção não surgiu entre os participantes desta pesquisa.

${ }^{36}$ Para Dumazedier (2001, p. 34), o lazer "é um conjunto de ocupações às quais o indivíduo pode entregar-se de livre vontade, seja para repousar, seja para divertir-se, recrear-se e entreter-se ou, ainda para desenvolver sua informação ou formação desinteressada, sua participação social voluntária ou sua livre capacidade criadora após livrar-se ou desembaraçar-se das obrigações profissionais, familiares e sociais".
} 
de modo geral e dominante, simboliza cultura, a SUSA, junto com o Grêmio Recreativo, se sobressai como um modelo de lazer ${ }^{37}$.

Ao ser criada em 1970 por um grupo de estudantes universitários santa-rosenses que passavam as férias do mês de julho na cidade, o seu objetivo era oferecer uma semana com diferentes atividades culturais, esportivas e de lazer principalmente para a população jovem. Sob a responsabilidade de uma comissão de universitários, programavam-se, a cada ano, apresentações musicais, gincanas, palestras, oficinas e desfiles de beleza.

Considerando que a cidade, formada majoritariamente por famílias descendentes de imigrantes e trabalhadores rurais de baixa renda, não possuía instituições de ensino superior e que cursar uma universidade era algo restrito a apenas uma pequena parcela da população, a SUSA, nos seus primeiros anos, não oferecia o mesmo apelo popular que viria a adquirir posteriormente. Segundo Boniperti, um dos entrevistados, quando ela surgiu, "era altamente elitista"; com efeito, seus pais nunca sequer tinham ouvido falar da semana, até que ele, depois de formado, começou a frequentá-la. Por outro lado, neste ambiente ainda fundador, foram possíveis discussões sobre a situação política dos anos 70, o movimento estudantil e o futuro do país.

Com as transformações sociais, a SUSA também foi se modificando e perdeu o papel mobilizador dos anos iniciais. Atualmente, ela continua sendo realizada todo ano e o seu sucesso e importância para os jovens da cidade ainda é lembrado, mas agora porque acreditam que ela é uma opção de lazer, em uma perspectiva dissociada da ideia de cultura com a qual estava fortemente relacionada há quarenta anos. Enfraquecida, observa-se um sentimento de nostalgia por algo que corre o risco de desaparecer, o que, como mostrou Gonçalves (2002) em relação aos discursos patrimoniais no Brasil, é uma das principais justificativas para nomear um bem como patrimônio cultural e desenvolver políticas para a sua "permanência" e "preservação".

Boniperti: Por mais difícil que seja organizar jovens, mobilizar, enfim, você formar grupos de interesse para a ação concreta, (a SUSA) não morre, tem, existe. Pode estar capengando, pode ter dificuldades, mas a Semana Universitária vai acontecer; grupos de jovens organizando uma semana com shows, com debates, com mostras,

\footnotetext{
${ }^{37}$ Segundo Aquino e Martins (2007), "ócio" é uma palavra mais abrangente que "lazer", pois enquanto o segundo pressuporia apenas atividades de descanso, diversão e desenvolvimento que são realizadas entre os períodos de trabalho, o primeiro incluiria tudo o que é realizado nas horas vagas relacionado ao "prazer da experiência", sem outro fim que não seja o enriquecimento da natureza humana. No entanto, preferimos utilizar o termo "lazer" em uma acepção ampla, pois foi com esta expressão que os participantes da pesquisa demonstraram sua preocupação inclusive com aquilo que os autores denominaram "ócio". Portanto, em muitos trechos, o leitor deve considerar "lazer" e "ócio" como sinônimos.
} 
enfim. (...) O pessoal não gostou muito desse ano. $\mathrm{O}$ que tem acontecido é que a juventude de Santa Rosa deu uma mudada tão grande, tão grande quanto aconteceu com a juventude em geral no Brasil. Música é sertaneja, carnaval é axé, zoeira tem funk, e isso está em todo lugar, não seria diferente aqui. A SUSA sempre teve uma tradição mais de MPB ou rock, então ficou meio vazio. A SUSA vai ter de se reencontrar.

Badra: A SUSA está perdendo a origem dela. Quando eu vim para cá com as crianças, quando ela começou, tinha um grupo de músicos que saíam na rua dançando; era tudo muito simples. Aí tinha gincana, a população participava mesmo. As crianças maiores participavam de gincana, teatro, competições. Agora está diferente. Tem uma programação, muitas vezes trazem um pessoal bom, por exemplo, artistas, e muitas vezes eles não têm um retorno nem para pagar o artista. O pessoal anuncia que vem uma banda ou um grupo de sertanejo, aí lota, precisa ser na praça, mas se traz um outro nível, você vê que o pessoal vai fazer o show lá no (bar) Curral.

Segundo Gonçalves (2002), é a ameaça de desaparecimento de um bem que mais mobilizou os defensores do patrimônio nacional pelo seu resgate, preservação e valorização. "Nessa perspectiva, o presente, assim como tudo o que é espacialmente próximo, aparecerá corroído por um processo de perda oposto àquela situação original - distante no tempo ou no espaço - definida por coerência, integridade e continuidade" (GONÇALVES, 2002, p. 24).

Para parte da população, a Semana Universitária é uma das poucas possibilidades de organização juvenil para instituir formas de entretenimento, diversão e desenvolvimento para esse mesmo grupo. Deste modo, sua extinção não acabaria apenas com uma atividade isolada, mas atingiria a juventude santa-rosense. Concomitantemente, devemos considerar que a sua existência há mais de quatro décadas permitiu que diferentes gerações a frequentassem, e, ao falarem da relevância da semana para os mais jovens, muitos utilizam como parâmetro não o perfil e gostos dos adolescentes atuais, mas suas próprias experiências em anos ou décadas anteriores, quando ela possuía outras características.

Mateus: (A SUSA existe) porque sempre existirão pessoas que vão sair, porque tem pessoas que querem tocar, mas não que seja um lugar valorizado ou acreditado pelas pessoas.

Daniela: Uma coisa que eu acho muito interessante, que eu não sei se em outras cidades tem, é a SUSA, a semana para os jovens se integrarem, ter aquela amizade, uma semana universitária.

Paula: A SUSA, Semana Universitária Santa-rosense, já foi uma boa opção de evento para apresentar a alguém que não mora aqui. No passado, principalmente na época de sua criação, esta semana estava intimamente relacionada à apresentação de cultura na cidade. Hoje, embora a SUSA tenha se distanciado de sua essência, ainda é um evento a ser apresentado para outras pessoas, pois ainda é uma semana peculiar na cidade. 
Hoje em dia, grande parte dos moradores acredita que a SUSA não mais congrega os predicados que possibilitou sua classificação, na década de 1970, como movimento ou atividade cultural. Entre as justificativas dos entrevistados para essa mudança de percepção estão os estilos de música agora adotados para as apresentações e mesmo o ambiente político, que teria deixado os jovens menos engajados com as questões socioculturais.

Apesar de a Semana Universitária ter começado a se enfraquecer apenas entre as décadas de 1990 a 2000, o argumento de que o clima político foi essencial para o seu sucesso é plausível. Como é sabido, foi na década de 1970, após o golpe militar de 1964, que o movimento estudantil se reorganizou no Brasil, estimulando jovens universitários a buscarem espaços de discussão e reflexão sobre os mais variados temas nacionais. Em contrapartida, desde os anos seguintes ao fim da ditadura militar, sua visibilidade e poder mobilizador têm diminuído. Especificamente em Santa Rosa, aquele pequeno grupo de estudantes universitários foi substituído por centenas de pessoas que têm a opção de estudar a noite em Ribeirão Preto e trabalhar durante o dia em Santa Rosa, mas que agora, não demonstram o mesmo interesse e disponibilidade de tempo que moveu o grupo inicial. O que auxilia na sua continuidade, nos últimos anos, é a contribuição financeira que a Fundação Cultural oferece para que os gastos com o evento sejam pagos.

\begin{abstract}
Mateus: Acho que a gente tinha que estar mais organizado, (a SUSA) tinha que ter mais apoio da prefeitura, dos comerciantes, devia ser uma coisa mais garantida, devia já ser maior. Porque eu peguei a SUSA dos anos 90, e o pessoal que pegou em 80 dizia que era melhor; os que pegaram nos 70 , melhor ainda, então é também a memória emotiva de quando você é muito jovem, com 14, 15 anos. Tudo é uma maravilha, a primeira vez que você sai de casa, a primeira vez que você vai à SUSA, que você vai ficar uma semana inteira saindo, indo à boate. Eu acho que pra molecada nova, os novinhos que estão começando a sair agora, com 15, 16 anos, deva ser uma maravilha, mas eu acho que é bem inferior (atualmente). Antes era mais cultural, porque tinha repressão, ditadura, várias coisas assim. Pra passar um filme era difícil. Passar um filme, durante a SUSA, era um máximo, ia todo mundo assistir. Hoje não, tudo é muito liberado, você tem tudo, então não tem mais tanta graça.
\end{abstract}

Deste modo, diferente do exemplo da Banda Sinfônica, uma ideia mais restrita de cultura fez com que a Semana Universitária perdesse prestígio entre a população. A sua defesa pelos entrevistados é feita principalmente pela sua história e continuidade e não pelo o 
que produz nos dias atuais. Assim sendo, torna-se ainda mais difícil a SUSA conseguir atenção da sociedade e recursos financeiros, pois não é considerada a partir do seu presente.

Entretanto, a existência de uma memória social que a considera um bem comum da população, reforçando sentimentos de pertencimento (POLLAK, 1989), permite que a SUSA seja vista como um patrimônio santa-rosense. Relembrar os acontecimentos da cidade nas últimas décadas desde 1970 passa pelo papel e transformações da Semana Universitária, pois refletiria as próprias mudanças na juventude local. Desta forma, a SUSA se insere na memória de acontecimentos que permanecem como pontos de demarcação na história de cada geração (BOSI, 1994).

Ao mesmo tempo em que a SUSA perde espaço entre os eventos da cidade, os entrevistados desejam que ela retorne aos moldes das décadas antecedentes acreditando na sua revitalização. Porém, devido às mudanças de interesse dos jovens relatadas pelos próprios entrevistados, repetir uma fórmula anterior não é garantia de sucesso. Ao invés de recuperar um modelo, poderia ser mais frutífero pensar a cultura da/ na cidade a partir do que hoje interessa aos mais jovens, dos estilos musicais aos lugares de encontro. Para isto, é necessário considerar que o que atualmente se realiza na Semana Universitária faz parte da cultura juvenil e mais importante do que o tipo de atividade realizada é a abordagem e a capacidade de reflexão que ela possibilita. Se em um determinado ano verifica-se uma grande influência da música sertaneja na cidade, como observam moradores, concomitantemente às apresentações musicais poderiam ser incluídas discussões sobre a história deste estilo e a relação com a própria região onde Santa Rosa se localiza. Nesse sentido, a Semana Universitária continuaria a oferecer aquilo que atrai o público, mas utilizaria esse sucesso para levantar questionamentos, permitindo, como alguns dos entrevistados anseiam, um caráter mobilizador e mesmo, em alguns casos, político.

Verificamos, ao discutir tanto a Banda Sinfônica como a Semana Universitária com membros da população, que as pessoas desejam atividades e espaços culturais devido à ideia positiva de cultura, mas não os consideram uma opção de lazer, deixando de usufruí-los em toda a sua potencialidade. Por outro lado, desejam opções de lazer, mas não as consideram atividades culturais. Portanto, se houvesse uma relação entre cultura e lazer, a cidade ganharia nestes dois aspectos e lugares e atividades seriam mais valorizados.

Segundo Aquino e Martins (2007, p. 482-483), a literatura sobre o lazer inclusive sugere que a sociedade seja estimulada a reconhecer os espaços de lazer e usufruí-los. O mesmo pode ser dito em relação aos espaços culturais, pois ao mesmo tempo em que determinadas concepções de lazer e cultura permitem que atividades e lugares sejam bem 
vistos pela população, elas também podem impedir que outras manifestações sejam reconhecidas, incentivadas e financiadas, mesmo quando são consideradas importantes em algum aspecto.

\begin{abstract}
Mateus: (A SUSA) não tem, realmente, uma atenção, um reconhecimento. Eu, por exemplo, nunca me interessei em dirigir uma SUSA, e quer saber?, a SUSA é um evento cultural, eu deveria ser um dos maiores interessados, mas você sabe que não vai ter a possibilidade de realmente fazer um negócio cultural. Você tem que fazer aquilo ali, colocar um $\mathrm{CD}$, chamar uns grupinhos que irão tocar o tipo de música que vai agradar, principalmente a molecada, porque quem frequenta é a molecada, e você não tem incentivo. Um momento desse, como a SUSA, não era para ser como um sábado à noite. Um momento desse é realmente pra resgatar valores, mostrar coisas que a molecada não tem contato e revalorizar.
\end{abstract}

Boniperti: Antes da SUSA, eu falava assim pra turma: “- Olha, clube universitário é maior que a Semana Universitária, não pode ser só (a semana)...” Então, como eu estava na Associação de Leitura do Brasil, chamei o presidente, o secretário, que são professores lá da Unicamp, para vir dar palestras para os professores de português. $\mathrm{Na}$ época, conversei com a delegada regional de educação e ela topou, juntou todos os professores da região e eles vieram dar palestras, uma de manhã e outra de tarde; eu achei super legal isso aí. Depois, durante a SUSA, amigas minhas que trabalhavam com educação especial vieram e conversaram, fizeram uma oficina com a turma da APAE. As da educação infantil vieram trabalhar com professores de educação infantil. Um amigo meu que é fotógrafo veio, deu um curso de fotografia. O bibliotecário da educação, que também era professor de dança de salão, veio e deu um curso de dança de salão. Todos os finais de tarde, no salão da SUSA, tinha dança de salão. Lotava, lotava... Foi muito legal trazer essa turma toda. (...) Na comissão, tinha gente da Ufscar, Unesp, Unesp de Rio Claro, Unesp de Franca (...) A comissão desse ano, praticamente, é todinha de estudantes universitários que moram em Santa Rosa e estudam a noite em Ribeirão. Me diga, como é que dá para conhecer alguma coisa cultural fazendo essa vida? Não dá. O ambiente universitário é imprescindível, e na verdade o pessoal chega, trabalha o dia inteiro, pega ônibus seis horas da tarde, desce na porta da escola sete horas, tem que entrar... (Assim) Não tem oportunidade, não tem contatos. Não é culpa deles, a SUSA foi a possível, é sempre a SUSA possível, então é legal, mantêm-se sempre. Talvez logo se ache.

Através dos exemplos da Banda Sinfônica e da Semana Universitária, observa-se que a identificação de patrimônios culturais, daquilo que é memorável para a população passa pelas suas representações sociais e a invenção e produção do novo (GONDAR; DODEBEI, 2005). No nosso caso, a ideia de cultura desenvolvida pelos entrevistados permitiu que um bem fosse ainda mais reconhecido e respeitado pela população, enquanto outro luta pela sua continuidade, porque, segundo os mesmos, vem perdendo o seu caráter "cultural".

Reconhecemos que qualquer bem possui mais de um significado cultural e, assim sendo, poderíamos ter discutido outros valores atribuídos tanto a banda como a SUSA. No entanto, neste capítulo, mais relevante do que apresentar todas as qualificações atribuídas aos 
bens vistos como os patrimônios culturais de Santa Rosa é demonstrar como determinadas representações influenciam diretamente no papel que estes bens exercem na cidade. Se na Academia, o conceito de cultura como um conjunto restrito de atividades artísticas e intelectuais é apresentado, de modo geral, como um mecanismo de discriminação, podemos verificar que os usos deste conceito pela sociedade produzem efeitos diversos, sendo em alguns aspectos até positivo. Neste sentido, concordamos com o historiador Marc Bloch (2001, p. 143) quando defendeu que "uma palavra vale menos por sua etimologia do que pelo uso que dela é feito".

O que salientamos, assim como fez Clifford Geertz (2008) em sua obra, é o risco de generalizações, de buscar uma teoria social total, universal, ao contrário de, através de casos específicos, entrar em contato com uma variedade de significações que demonstram as exceções e limitações de concepções dominantes.

Seria ingênuo acreditar que o valor histórico é suficiente para legitimar um patrimônio cultural perante a sociedade, apesar da existência desta possibilidade, pois, como observou Bloch (2001), o conhecimento e as representações que produzimos sobre o passado estão em constante movimento. No nosso exemplo, a Semana Universitária Santa-rosense, apesar do seu valor memorial, vem perdendo o seu prestígio perante a população, mesmo sendo reconhecido o papel que ela exerce na cidade há mais de quarenta anos.

Assim, o que entendemos por "mundo real" nada mais é do que o fruto dos nossos sentidos, sentimentos e capacidade de imaginar (PESAVENTO, 2007, p. 11-12), o que contribui para apontarmos os diferentes usos de determinadas noções, como de cultura, na construção do nosso passado, até porque "ao inventar o passado, contando a história de suas origens e de seu percurso no tempo para explicar seu presente, a cidade constrói seu futuro" (PESAVENTO, 2007, p. 17).

\subsubsection{A Fazenda Amália}

Entre os lugares e eventos da cidade, no entanto, nada se destaca mais que a Fazenda Amália, onde a maioria dos habitantes morava até a década de 1960. Exatamente pela sua representatividade, a fazenda não é lembrada em apenas um aspecto, mas é valorizada em toda a sua aparente contradição: de conglomerado agroindustrial que explorava seus funcionários a origem e motor do crescimento de Santa Rosa. Para os entrevistados, a fazenda em si, pela sua historicidade, poderia, inclusive, ser considerada um museu que expõe o começo e desenvolvimento do município. 
Cheyenne: Eu mostraria a Amália, porque é onde nasceu Santa Rosa, a cidade se fez daquela fazenda (...). A Amália podia já ter um guia de turismo, que levasse as pessoas e explicasse a história de Santa Rosa, porque é super interessante como é que surgiu essa cidade a partir daquele local, daquela fazenda.

Daniela: (...) (Na Amália,) eles podiam colocar uma placa para ter visitas, porque o acesso lá não é permitido, é mais restrito. Você não pode chegar lá (e dizer:) “ Vamos fazer uma excursão, vamos visitar a Amália, ver como que era a indústria, a usina”. Não tem como (...).

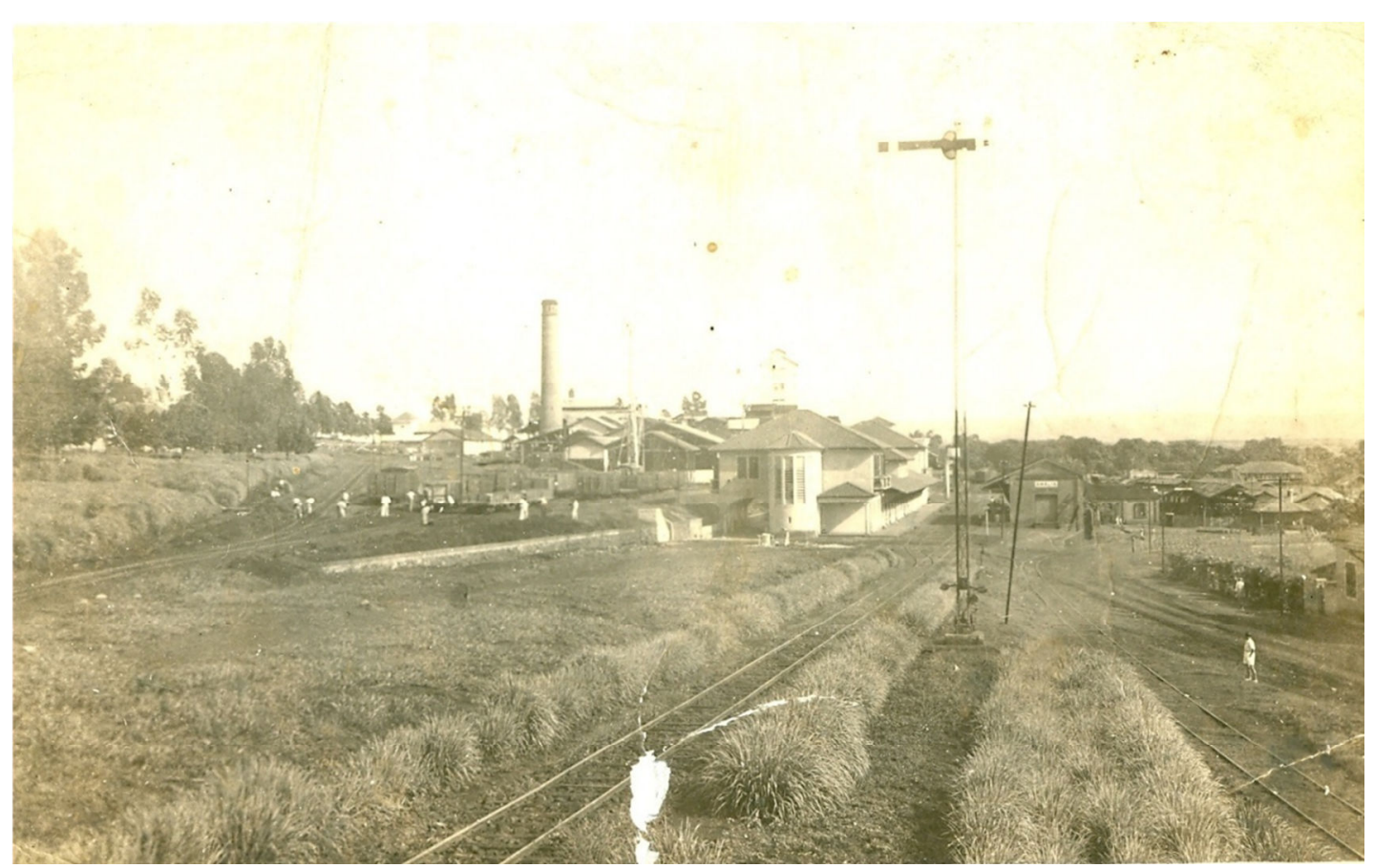

Fig. 10: Fazenda Amália no início do século XX

É em relação ao poder econômico da fazenda que encontramos a maior diversidade de opiniões. Enquanto alguns enfatizam seu caráter monopolizador, que deixava Santa Rosa dependente, outros sublinham o papel desempenhado pela Amália na industrialização do município. Percebe-se que mesmo após várias décadas, as dificuldades sofridas pela população devido a essa subordinação ainda estão em destaque na memória social, demonstrando certo ressentimento pela posição destinada ao trabalhador comum, às classes mais baixas. Por outro lado, após um distanciamento de vários anos, outros preferem uma análise mais global e histórica, acreditando que apesar desses problemas ter existido, uma 
leitura do presente mostraria que eles são menores em comparação a contribuição da fazenda para a industrialização e crescimento da cidade.

Badra: A população toda dependia da Amália e era fazer tudo o que seu mestre mandava. Então, o próprio comércio, a vida econômica e social da cidade ficou na dependência dela. Houve uma época que de quatro em quatro anos a Amália mandava embora os funcionários, afundava economicamente a vida da cidade como um todo. A população sentia isso e nós, do comércio, sentíamos muito mais. (...) Em contrapartida, com tudo que a população fez, trabalhou, que ela (a Amália) sugou de Santa Rosa, ela não devolveu nada, simplesmente mandou embora.

Omar: Se você comparar a nossa cidade com cidades do mesmo porte da região, você vê que nós temos uma oferta de emprego muito maior. Isso se deu pela instalação do polo industrial na Fazenda Amália. Desde a década de 20, Santa Rosa é uma cidade industrial. Uma cidade que dispõe de mão de obra na área industrial.

Romeu: Do ponto de vista econômico, é uma cidade privilegiada, porque tem um parque industrial formidável e atípico para um município desse tamanho. Cidade com pouco mais de vinte mil habitantes, tem um parque industrial fantástico que é fruto do empreendedorismo do Henrique Santos Dumont completado pelos Matarazzo. Então, do ponto de vista econômico, Santa Rosa é destaque.

Diferentemente da Banda Sinfônica e da Semana Universitária, que são reconhecidas pelas instituições culturais locais, não nominalmente, mas discursivamente como patrimônios, a Fazenda Amália não desperta o mesmo interesse público pela sua preservação. Apesar de não negarem sua relevância, a fazenda não participa de projetos municipais relacionados à cultura ou ao patrimônio, e a falta de interesse dos seus proprietários tem permitido que as construções históricas da fazenda e todo o seu entorno fiquem abandonados e em deterioração. Além disso, por estar a seis quilômetros da cidade, fez com que a maior parte da população deixasse de frequentá-la quando se mudou para a cidade.

Boniperti: Eu morei lá (na fazenda) até os seis anos. Eu fiquei muito triste (com a destruição das construções). Eu estudei a primeira série na escola de Amália, no grupo de lá. Só ficou a parede da frente e, segundo consta, informações confiáveis, não tinha uma goteira no prédio todo. (O prédio) estava perfeito e destruíram, foi ao chão. Eu tenho muitas lembranças daquela primeira série lá, tenho muita lembrança, e está no chão. É chato. A casa em que eu morei está lá ainda, uma das poucas coisas. Eu morava em frente ao mercado de Amália.

Para muitos, a Fazenda Amália é a origem da cidade, e a história do município só se construiria a partir dela. Os habitantes não dividem a cidade e a fazenda em dois núcleos 
distintos, mas como complementos que se explicam. Apesar de a cidade ter crescido e a sua população e economia diversificada, grande parte da população ainda depende dos empregos da fazenda, além da maioria ter parentes ou mesmo já ter morado no local. Quando questionados sobre o que mostrariam para um visitante de Santa Rosa, a referência à fazenda é constante, até porque consideram o lugar mais conhecido para os não moradores. É frequente, inclusive, relacionar a história da fazenda, da família Matarazzo, principal proprietária das terras durante a maior parte do tempo, com a história do país. Assim, a fazenda deveria ser lembrada não apenas pela sua importância para o município, mas por fazer parte da história econômica nacional, com destaque para o Estado de São Paulo. Reforça ainda mais essa concepção a existência de um palacete da família Matarazzo nas dependências da fazenda, onde seus membros passavam férias e eram admirados pelos empregados como uma das famílias mais ricas e conhecidas do Brasil. Desse modo, construindo uma relação entre o local e o global, Santa Rosa e a nação, os moradores recorrem à Amália como um mecanismo identitário, um ponto de ligação e diferença entre nós e os outros.

Entrevistador: Você acha que a Fazenda Amália é valorizada pela população? Omar: Eu acho que sim, porque se você pegar o pessoal que mora aqui na cidade há mais de uma geração, vamos pôr vinte, trinta anos, praticamente $80 \%$ da população tinha ou alguém da família ou alguém que trabalhou na Fazenda Amália.

Entrevistador: Você acha que a Fazenda Amália é valorizada na cidade?

Daniela: Na minha opinião, eu acho que deveria ser mais, porque tem um pouco a ver com a formação (da cidade), foi a partir dali que começou a se formar. Vieram famílias trabalhar aqui. Até meus vizinhos que são mais antigos; eles todos moravam na Amália. Então já formou aquela amizade, uma coisa de família. Eu acho que deveria ser mais valorizada. Agora se perdeu um pouco pela questão da divisão da herança, essas coisas. Isso deveria até se tornar um patrimônio da cidade. Eu não sei se é, mas deveria se tornar um patrimônio.

Entrevistador: Se você recebesse uma visita e ela lhe pedisse para você mostrar a cidade a ela, um lugar, uma festa, um evento que você acha que lembra Santa Rosa, que é "a cara" da cidade, o que você mostraria?

Daniela: (...) A Amália, porque é uma coisa que eu tenho como referência da cidade. (Quando) falam “- Onde que é Santa Rosa?”, (eu respondo): “ - Ah, você nunca ouviu falar da fazenda Amália? Do Conde? Então, é lá que ele morou; “ - Ah, nossa, é lá, eu já ouvi sim falar, mas nunca tive oportunidade de ir, mas tenho curiosidade de ver". Então é um lugar que eu colocaria como referência.

Cheyenne: A Amália... foi o motivo da gente ter a cidade aqui, do seu desenvolvimento. 
A fazenda ainda é mencionada pelo seu aspecto antigo, que no senso comum também é sinônimo de histórico. Alois Riegl (1990), no início do século XX, já observava como o valor de antiguidade é um dos mais facilmente percebidos por todas as classes sociais, pois ao primeiro contato, a partir do contraste, determinam o que é e não é moderno, novo. Para ele, as paredes danificadas, corroídas, a alteração de forma e cor despertam em quem olha "a sensação do tempo transcorrido" (CUNHA, 2006, p. 10), acentuando a preocupação com sua conservação.

André: A Fazenda Amália é um lugar histórico. Você vai lá, têm uma locomotiva antiga, prédios antigos.

Segundo Augé (2004, p. 36-41), as ruínas encantam porque possibilitam uma experiência do tempo. Através de sua funcionalidade perdida, se dirigem a múltiplos passados sempre de forma incompleta, adquirindo pela sua beleza enigmática o status de arte. Um exemplo desta percepção é quando os entrevistados, ao comparar a fazenda a um museu ao ar livre, acreditam que visitá-la permite visualizar parte da origem e desenvolvimento do município.

Somente as ruínas, enquanto forma de uma recordação, permitem de escapar dessa desilusão: elas não são a recordação de ninguém, mas se apresentam a quem as percorrem como um passado que ele havia perdido de vista, esquecido, e que, todavia, lhe diria ainda alguma coisa. Um passado no qual ele sobrevive (AUGÉ, 2004, p. 74, tradução nossa).

Pelo significado que tem para a população como origem da cidade, lugar de trabalho e moradia, museu, modelo econômico, entre outros, a fazenda é claramente um lugar de memória e identidade para os moradores de Santa Rosa, que só reconhecem a cidade e sua história a partir da Amália. Mesmo com dúvidas sobre o papel que ela deva ocupar em uma política pública, não deixam de descrevê-la como um patrimônio cultural.

Ao questionarmos o que um museu deveria exibir sobre a cidade, a principal resposta foi a fazenda, pois acreditam que a "Amália é tão conhecida quanto a cidade, pelo fato de ter esse polo industrial dos Matarazzo, que hoje nem é mais da família Matarazzo" (Omar). Devido ao tempo e a quantidade de pessoas que viveram neste local, qualquer produto/ objeto/ 
construção da fazenda é facilmente reconhecido pelos santa-rosenses, que os inserem em uma rede de significados e lembranças. Deste modo, "a memória topográfica articula as recordações (aquelas que vêm do coração) a espaços vividos, carregando-os de sentido simbólico: torna os lugares testemunhas de histórias" (FREIRE, 1997, p. 133).

Assim sendo, a Fazenda é discursivamente construída como uma síntese da história local, um microcosmo que justificaria a existência de Santa Rosa e explicaria suas características. Desta forma, mesmo fora do perímetro urbano, fechada em uma propriedade privada e distante dos seus antigos moradores e prováveis visitantes, ela é sempre referenciada em seus mais diferentes atributos, sejam eles positivos ou negativos.

\subsubsection{A Folia de Reis}

Nesta relação entre a área urbana e a fazenda, as festas são o que melhor evidenciam a influência do espaço vivido na continuidade de expressões culturais. Como já discutimos, na Fazenda Amália aconteciam manifestações como Folia de Reis, Festa de São Gonçalo, Congado, encontro de violeiros, sanfoneiros e bailes que se configuravam como momentos de sociabilidade e lazer. Tais eventos não eram exclusivos da Fazenda, também ocorrendo na zona urbana e outras cidades. Nem podem ser considerados típicos da região, ao contrário dos discursos sobre a SUSA. Contudo, a composição da fazenda, com pessoas provenientes da mesma classe social e sem grandes possibilidades de mobilidade permitiram um estado de coesão social para o compartilhamento e florescimento destas práticas com grande dispersão no mundo rural e cultura caipira.

Sem opções de lazer como as quais se encontram nas cidades, esses eventos se destacam como o contraponto ao tempo do trabalho, que não oferecia oportunidades de crescimento profissional e salarial. Desta forma, eles são lembrados pelos antigos moradores locais como exemplos positivos de confraternização, diversão e expressão de sua cultura em um ambiente de dominação oligárquica, ajudando a explicar o porquê de a fazenda ser elogiada por vários santa-rosenses ao mesmo tempo em que é sabido que nela ocorriam greves, trabalhadores tinham seus direitos negados e centenas foram expulsos do local.

$\mathrm{Na}$ área urbana, com a fragmentação desses antigos núcleos de moradores rurais, a imigração de pessoas de outras partes do país, a emigração de alguns santa-rosenses expulsos da fazenda, o oferecimento de novos serviços e o surgimento de uma nova geração diminuíram o prestígio e destaque que essas festas possuíam entre os habitantes. A partir deste período, ao invés de serem eventos de toda a comunidade, se restringiram a uma 
determinada localidade ou simplesmente se extinguiram, como nos casos da Festa de São Gonçalo e do Congado.

Um bom exemplo a ser discutido é a Festa ou Folia de Reis. Na antiga divisão entre espaço urbano e rural, ocorriam apresentações em ambos os lugares. Depois da década de 1970, quando a cidade passou por diversas transformações aqui citadas, ela começou a se enfraquecer. Restrita somente aos grupos mais antigos, acreditava-se que ela chegaria ao seu fim em Santa Rosa. No entanto, no momento da institucionalização dos espaços e eventos culturais no município a partir de 1985, ano de surgimento da Fundação Cultural, a Folia de Reis foi inserida no calendário municipal e passou a ser organizada pelos administradores locais.

Boniperti: Na verdade, em 85 , foi tomada uma providência, porque ela já estava acabando, estava diminuindo o número de grupos.

Novamente, a ideia de tradição foi retomada para justificar o investimento da prefeitura. Assim, o fato da Folia estar presente na cidade há várias décadas, sem a precisão de uma data, sustenta o argumento de que ela deve ser assegurada, mesmo que os mais novos não demonstrem interesse pela sua manutenção. Como defende Maurílio de Oliveira Júnior, "tem Folia de Reis desde que a cidade é cidade. E por quê? [Porque] faz parte da vida da cidade estas manifestações. Então tem que apoiar”.

Ao preferir enfatizar as continuidades às rupturas, a princípio a Fundação apenas colaboraria com a sobrevivência da festa, mas ao observamos que agora ela é também um evento oficial, sem a espontaneidade e disseminação das décadas anteriores, realizada em uma data pré-definida e em um local centralizador, que desde então é o Bosque Municipal, concluímos que a sua essência, ou seja, uma oportunidade de expressão da cultura popular, não é mais a mesma.

André: [De cultura na cidade], tem o Encontro de Reis, que é um resgate. A juventude de hoje não conhece muito bem o que é e [mesmo assim] isso é mantido aqui em Santa Rosa.

Romeu: [De] tradição, tem essa Folia de Reis, que eles preservam aí... 
Ao contrário da Fazenda, que desestimulava a Folia de Reis e, em alguns casos, impedia sua realização em sua área central, após 1985, no bosque municipal, ela passou a ser celebrada como parte da identidade santa-rosense, algo que merecesse ser transmitido para as futuras gerações. Separada do cotidiano, sua realização neste lugar não mais se resume a atender os hábitos e anseios de seus praticantes e público, mas também legitimar perante os mais jovens e desinteressados a sua condição de representante de uma cultura. Neste sentido, torna-se possível alguém não gostar do estilo de música executada, o público que a frequenta, o lugar no qual ela se realiza, mas ainda assim defini-la como relevante culturalmente, porque, nesta condição, ela se apresenta como uma tradição.

Apesar de não estar explícito no relato a seguir de Boniperti, que pela sua história pessoal ainda exalta o papel subversivo da Folia na Fazenda Amália, esta transformação é uma das razões que explica porque mesmo não sendo frequentada por parte dos moradores, estes a identificam como um patrimônio santa-rosense:

Boniperti: Eu detestava quando era jovem, e depois, por ter que trabalhar com isso, eu passei a adorar, que é a Folia de Reis, o encontro de Folia de Reis. Passei a respeitar e achar muito bonito porque - não pelo viés religioso, que eu acho que até se afastou bastante -, [mas] porque é o dia de estrela dos oprimidos, dos lavradores. Os trabalhadores rurais viram estrelas da música, vão cantar, se apresentar, serem aplaudidos, e isso é bonito pra caramba. [...] Nós temos muitos valores a serem preservados dessa cultura popular, valores que hoje estão de certa forma esquecidos. [...] as roupas de Folia de Reis, por exemplo, são todas roupas de retalhos; isso vale. [...] Eu acho que nela a gente vai encontrar alguns valores. [...] A gente vê valores como amizade, lealdade, fidelidade, desprendimento, que nós não encontramos hoje na sociedade.

Reinventada por uma decisão política, ela também se tornou um evento turístico anual, com financiamento da Fundação Cultural e a participação de companhias e visitantes de diversas cidades da região. Por outro lado, enquanto o Encontro de Folia de Reis acontece no bosque do município, verificamos que outros eventos extrapolam a ordem institucional. No período de Santos Reis, de 24 de dezembro a 6 de janeiro, companhias de foliões, sem uma organização centralizada, percorrem a cidade visitando casas em troca de alimentos e dinheiro. Não existe um convite formal para uma visita. Os grupos passam pelas ruas tocando, cantando e dançando, e são recebidos em casa por aqueles que abrem suas portas ou aparecem no portão. Se uma casa está fechada é sinal que não deseja receber a companhia, não sendo incomodados seus moradores. Alguns a recebe por gostar da música, da beleza das fantasias, outros porque acreditam que uma recusa aos foliões, mesmo que simbolicamente no ato de 
fechar suas casas, é uma ofensa aos Santos da Igreja Católica, portanto um pecado. Durante uma visita, a companhia permanece alguns minutos dentro da casa, geralmente na sala, toca algumas músicas e, ao final, recebe sua oferenda.

Durante todo o ano, homens com bandeiras de Santos Reis, que se configuram por suas cores extravagantes de tecidos, fitas e flores, a imagem dos três santos e diversas fotografias de pessoas que receberam ou pediram milagres, também esmolam pelas casas em troca de alimentos e dinheiro. Nestes casos, eles solicitam a presença de um morador da casa mesmo quando este não demonstra nenhuma atitude em favor do seu recebimento. Entretanto, raramente eles entram nas residências, mas aqueles que aceitam a visita, pegam a bandeira, percorrem os cômodos da casa com ela em punho para evocar proteção divina e, depois, a devolvem ao dono com uma contribuição.

No centro da cidade, na casa de um morador, há apresentações de um conjunto com as mesmas características dos da Folia de Reis, a Companhia dos Mensageiros do Oriente, contudo realizada por iniciativa popular e sem relação com a Fundação Cultural. Na Cohab II, no Clube dos Santos Reis, há dezesseis anos, realiza-se a Folia do Divino, semelhante à Folia de Reis, mas sem acordeon, entre 12 de outubro e 13 de dezembro e dedicada às crianças. Desta forma, apesar de renovada para permitir uma estrutura administrativa em parceria com a prefeitura, a Folia de Reis e suas variantes não se limitaram às apresentações realizadas no Bosque Municipal, mas coexistem diferentes leituras religiosas promovidas por diversos grupos locais.

A iniciativa da Fundação Cultural, em 1985, de promover uma expressão religiosa e cultural que na zona urbana não alcançava todos os moradores foi importante para que os antigos foliões não se dispersassem e perdessem a convivência que permitia sua existência. A Festa de São Gonçalo, por exemplo, presente nas colônias da fazenda, não recebendo a mesma atenção, se extinguiu com os anos e seus realizadores já não conhecidos. Já a Folia, com o surgimento e manutenção de outros grupos, diferentes entre si, garantiu que algumas das características que a vinculam à fazenda fossem preservadas: a procissão pelas ruas, a visita das casas, o recebimento da bandeira, as oferendas, etc.

A dúvida é que se, com os anos, as novas gerações conseguirão ou se interessarão em preservar, primeiro, as rupturas que permitiram a Folia de Reis ser vista pela população como uma tradição e patrimônio cultural e, depois, as continuidades que a mantém vinculada à Fazenda Amália. Na opinião de Boniperti: 
A gente não vê muita criança na Folia de Reis, mas, ao mesmo tempo, muitos grupos vão se renovando e vêm se mantendo. Eu acho que vai diminuir, mas eu acredito que não vai acabar, até porque é uma forma de extravaso, de extravasamento do homem do campo.

De qualquer forma, independentemente se irão sobreviver às preferências das novas gerações, urbanas e em trânsito por cidades próximas, principalmente Ribeirão Preto, exemplos como a SUSA, a Banda Sinfônica, a Fazenda Amália e as Festas, com destaque para a Folia de Reis, permitem-nos reconstruir e compreender os processos pelos quais determinados bens são valorizados e classificados como patrimônios culturais pelos moradores e os discursos que os caracterizam como símbolos de identidade e memória social. Assim sendo, mesmo sem um reconhecimento oficial de seu caráter patrimonial, os habitantes, influenciados pelas ações promovidas por instituições públicas e com poder de legitimação, incluem essas expressões, simbolicamente, nesta categoria, solicitando e justificando sua preservação, valorização e divulgação.

5.2.5 A Banda, a Semana, a Fazenda e a Folia: a junção de valores e sentidos na formação de patrimônios

Observa-se que, com exceção da Banda Sinfônica, os bens que apresentamos como patrimônios culturais são também criticados por parte dos moradores devido às suas transformações nas últimas décadas, como nos exemplos da Semana Universitária e da Folia de Reis, ou porque uma relação de subordinação e exploração foi desenvolvida, como na Fazenda Amália. Ao lado de diversos elogios que explicam a relevância dessas expressões e lugares para a cidade, encontramos depoimentos que destacam o seu abandono e dificuldades de continuidade. Portanto, não é uma unanimidade entre os entrevistados dizer que todos são patrimônios locais. Nesta situação, na conjuntura desta pesquisa, o que sustenta a afirmação de que estes quatros bens são patrimônios culturais santa-rosenses? Algumas características devem ser analisadas.

Primeiro, não há contradição entre serem vistos como símbolos identitários e mnemônicos por alguns e irrelevantes e sem importância por outros. A partir do momento em que consideramos que um estado de estabilidade e unanimidade, como discutido por Halbwachs (2004), só é possível em comunidades muito pequenas e isoladas ou em situações raras, qualquer outra análise do social deve considerar a convivência de pontos de vista conflitantes. Depois, a existência de valores negativos também pode ter contribuído para o 
papel de destaque que esses bens adquiriram no imaginário popular. A Fazenda Amália, por exemplo, envolvida em críticas e processos judiciais de ex-funcionários, não se desvincula do dia-a-dia nem daqueles que gostariam de esquecê-la, oferecendo para aqueles que a julgam positivamente um espaço para discussão e declaração dos seus sentimentos. Deste modo, não restrita a apenas uma característica, ela é, a todo o instante, vinculada aos santa-rosenses, que a identificam como uma influência determinante em suas antigas e atuais condições sociais, econômicas e culturais.

Outro suposto problema é que esses bens não são definidos, oficialmente, como patrimônios culturais, o que impediria esta qualificação. A cidade não possui uma instância em funcionamento que os identifiquem e estabeleçam os mesmos processos de preservação, classificação e divulgação como realizados por instituições como o IPHAN ou o Conselho de Defesa do Patrimônio Histórico, Arqueológico, Artístico e Turístico do Estado de São Paulo (CONDEPHAAT). Em contrapartida, a inserção de alguns desses eventos em um calendário municipal de atividades culturais permite que eles sejam legitimados institucionalmente, recebam recursos públicos e adquiram condições de alcançar grupos além dos seus promotores.

Em nossa abordagem, que privilegia o discursivo e o simbólico, estas medidas são suficientes para considerá-los patrimônios culturais, porque se os administradores não os citam desta maneira, justificam as ações tomadas a partir da evocação de conceitos como "tradição", "identidade", "memória" e "cultura". Neste aspecto, destaca-se o papel que a Fundação Cultural exerce na construção dos sentidos atribuídos a determinadas expressões. Contudo, como tal relação não é explícita, não é possível aos entrevistados afirmar que alguns bens são patrimônios simplesmente porque foi assim definido, mas são necessárias argumentações que sustentem esse ponto de vista.

Foi exatamente este deslocamento que despertou nosso interesse por Santa Rosa. Mesmo com algumas políticas culturais, os entrevistados não possuíam uma lista pré-definida para dizer quais eram os patrimônios de Santa Rosa, exigindo, por parte destes, uma mediação entre suas impressões e sentimentos com as decisões já tomadas pela Fundação Cultural. Assim sendo, ao mesmo tempo em que reproduzem expressões do senso comum como "é bom porque é cultura", recorrem às suas experiências pessoais para o estabelecimento de uma narrativa própria, baseada nos usos destes lugares e eventos.

Neste conflito, entre o que um acredita ser significativo e o outro irrelevante, entre as minhas percepções e a ordem estabelecida pelos governantes, consegue-se desnaturalizar o patrimônio cultural. Ele torna-se contextual, circunstancial, temporal e localizável, 
diferentemente dos bens forjados como tais na formação dos Estados Nacionais. Isto não significa que as narrativas nacionais eram marcadas pela ingenuidade; pelo contrário, utilizar esta perspectiva foi essencial para transmitir as ideias de unidade e nação que se buscava no período. No entanto, nos dias atuais, em um mundo, ao mesmo tempo, fragmentado e globalizado, se desejamos analisar os patrimônios pela ótica social, não há como negar a existência da diferença e contradição.

Este processo de significação pode ser mais bem ilustrado pelos conceitos de “codificação" e "decodificação" de Stuart Hall (2009). Contrapondo-se ao modelo unidirecional de transmissão da mensagem do emissor para o receptor, o autor defende a abordagem de que não há transparência e linearidade neste percurso e que, na maioria das vezes, o que é produzido pelo emissor é diferente daquilo que é apropriado pelo receptor.

Aplicado à construção discursiva de patrimônios, podemos entender que, ao promover um bem cultural como símbolo local, a Fundação Cultural utiliza sentidos já existentes na sociedade para "codificá-los" em um conjunto de significados que ela espera ser o dominante. Através de conceitos como de "cultura" e "tradição", por exemplo, já compartilhados pela população, propõe-se que a Semana Universitária seja vista como um modelo de "cultura e lazer" e a Folia de Reis de "tradição popular". Entretanto, no momento de "decodificar" essas mensagens, os grupos sociais não se limitam a reproduzir os "significados preferenciais", como denomina Hall, mas, a partir de suas experiências e dos contextos nos quais estão inseridos, os ressignificam.

Para o autor, existem três posições de decodificação: a hegemônica-dominante, a de oposição e a negociada. No primeiro caso, o indivíduo se apropria de sentidos iguais ou muito semelhantes àqueles elaborados pela "codificação", reproduzindo o significado preferencial. De maneira aproximada, é o que verificamos com a Banda Sinfônica, pois mesmo aqueles que não frequentam suas apresentações ou não possui uma ligação direta com a Estação da Cultura a valorizam como uma oportunidade para se "adquirir" cultura. A de oposição ocorre quando, no ato de decodificação, é realizada uma leitura contestatória do sentido codificado, permitindo um embate entre os significados atribuídos. Já a negociada, que para segundo Hall é a de maior incidência, representa uma simultaneidade e diálogo entre as definições hegemônicas e as de questionamento.

Em nossa pesquisa, foi esta última posição a que mais observamos. Mesmo reconhecendo as leituras institucionais da Semana Universitária, da Fazenda Amália e da Folia de Reis, as representações dos moradores extrapolam essas significações. A Folia de Reis não se limita aos eventos no Bosque Municipal, existindo apresentações nas ruas e em 
casas espalhadas pela cidade. A SUSA, ao mesmo tempo em que é apoiada como uma atividade de lazer, recebe críticas pelas suas alterações ao longo dos anos, e a Fazenda Amália, frequentemente citada pelo seu poder econômico e político, também é lembrada pelas manifestações culturais de seus habitantes, seja em sua área central como nas antigas colônias dentro da Fazenda.

Desta forma, discutimos o patrimônio cultural não a partir de uma ideia de consenso, mas por meio da produção de significados que garantem seu lugar de destaque entre os diversos bens locais. Ao contrário de defender uma perspectiva de unanimidade, acreditamos na coexistência de comunidades interpretativas ou imaginadas, como define Anderson (2008), que compartilham "decodificações" possivelmente opostas às de outros grupos. Assim, privilegiamos as mediações que autorizam determinados bens serem considerados patrimônios culturais, mas que não impedem interpretações contestatórias que produzem conflitos e contradições.

O próprio prédio da Fundação Cultural é um reflexo desta coexistência de diferentes leituras. De 1914 a 1976, a sua atual sede foi o posto policial da cidade, no qual eram enviados os criminosos e as investigações policiais eram realizadas. Em 1976, com a inauguração de uma nova cadeia, maior e com melhor estrutura para atender a demanda do município que crescia, o edifício ficou abandonada por mais de vinte anos, quando, em 1997, foi restaurado para ser a sede da Fundação Cultural, que funcionava na Estação da Cultura. Inaugurada em 1998 e em funcionamento desde 2000, a Fundação não mudou mais de prédio, mas até hoje é comum a população denominar a construção não como o polo da administração cultural, mas como a "cadeia velha".

Em sua reforma, a fachada do posto policial foi mantida, inclusive com a inscrição "posto policial", mas seu interior foi readaptado para receber as salas dos administrados culturais e seu entorno foi transformado em uma praça, com bancos de madeira e plantas ornamentais. Entretanto, a sua função e imagem social permaneceram a mesma, a de "cadeia", não sendo substituída pela construção de uma nova, a chamada "cadeia nova". Por conseguinte, sua praça não se configura como um lugar de encontro e lazer, como nas outras da cidade, mas apenas um lugar de passagem. 


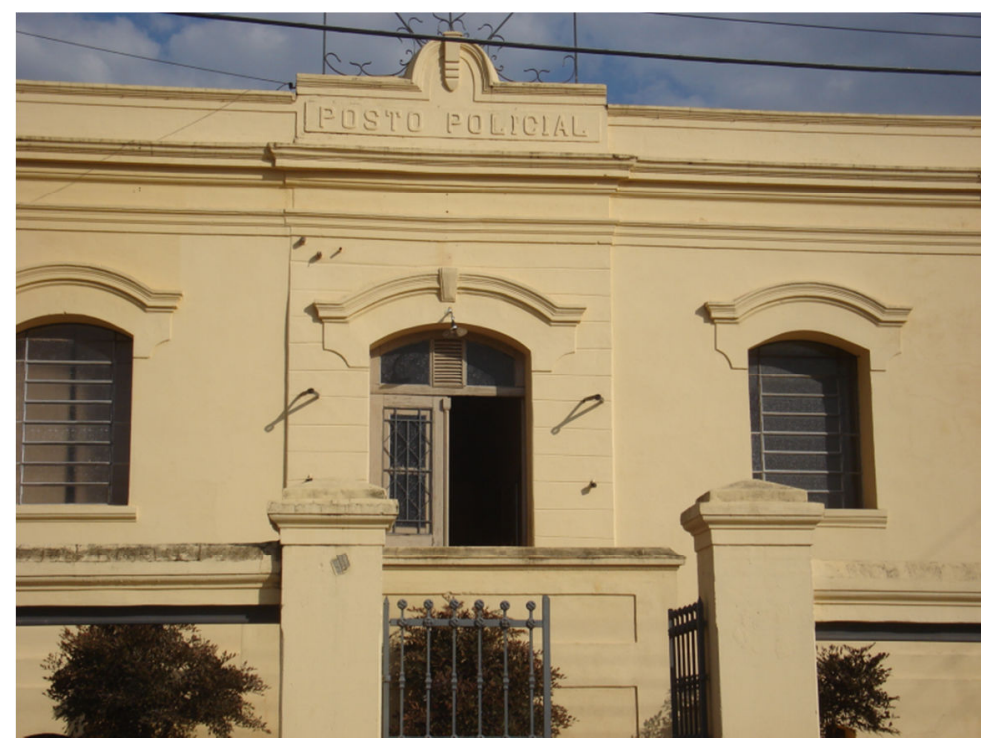

Fig. 11: Sede da Fundação Cultural com a inscrição "Posto Policial” na fachada

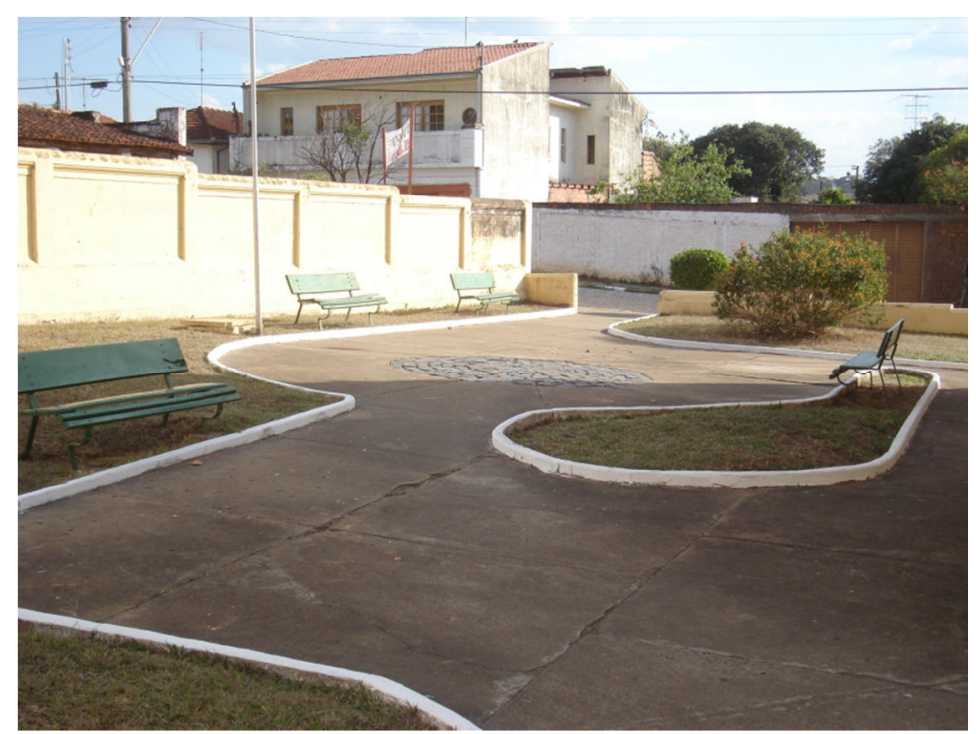

Fig. 12: Área externa da sede da Fundação Cultural

Verificamos, assim, os usos e contra-usos da cidade, como analisados por Leite (2007) em Recife. O autor utiliza esses conceitos para discutir o processo de gentrification, ou seja, de enobrecimento urbano, do Bairro do Recife, localizado na cidade com mesmo nome. $\mathrm{O}$ objetivo dos responsáveis por estas políticas em Recife era retirar os moradores e passantes "indesejáveis" do local, transformando o bairro em um lugar turístico, com serviços e produtos destinados aos visitantes das classes médias e altas. No entanto, a ordem espacial e os sentidos preferenciais produzidos sobre o bairro não foram apropriados em toda a sua totalidade, como sempre acontece segundo Hall (2009), e contra-usos, que são os usos 
inesperados e transgressores, foram realizados por moradores locais, principalmente moradores de ruas, prostitutas e usuários de drogas.

Em Santa Rosa, os quatro bens citados em nossa pesquisa não se reduziram apenas ao significado dominante, mas, por meio de diversos usos e práticas sociais, se transformaram em condensadores, agregadores de sentidos, destacando-se entre os outros bens locais exatamente por reunirem uma ampla variedade de valores produzidos e compartilhados, sejam de forma complementar ou contestatória, por diferentes grupos sociais. Desta forma, enfatizamos o processo que permite denominar uma obra como patrimônio cultural mesmo quando não existe consenso em relação à sua imagem, desconstruindo a aparência de estabilidade e unanimidade presentes em alguns discursos nacionais sobre o patrimônio.

Não negamos a influência dos sentidos preferenciais, como aqueles produzidos pela Fundação Cultural, para a manutenção, valorização e divulgação desses bens, principalmente no caso da Banda Sinfônica, mas, ao mesmo tempo, mostramos como os indivíduos desenvolvem, dentro das leituras possíveis, seus próprios percursos interpretativos. Como argumenta Certeau (2004) em relação ao espaço:

(...) se é verdade que existe uma ordem espacial que organiza um conjunto de possibilidades (por exemplo, por um local por onde é permitido circular) e proibições (por exemplo, por um muro que impede de prosseguir), o caminhante atualiza algumas delas. Deste modo, ele tanto as faz ser como aparecer. Mas também as desloca e inventa outras, pois as idas e vindas, as variações ou as improvisações da caminhada privilegiam, mudam ou deixam de lado elementos espaciais (CERTEAU, 2004, p. 177-178)

Assim, o patrimônio se apresenta nas interseções entre a história e a memória, vivência e representação, permitindo decodificá-lo a partir da observação de um conjunto de práticas e mediações que o classifica como um símbolo identitário e cultural. 


\section{O PATRIMÔNIO CULTURAL COMO PROCESSO: POR UMA IDÉIA QUE SUPERA A OPOSIÇÃO MATERIAL-IMATERIAL}

Após a exposição de quatro exemplos que se configuram como patrimônios nas representações dos moradores, algumas características devem ser analisadas. Observa-se que os entrevistados não separam o aspecto intangível do tangível de cada bem cultural, relacionando a sua materialidade com os significados que eles adquiriram. Enquanto a Banda Sinfônica é valorizada pelo seu caráter "cultural”, reconhece-se que tal relação só é possível porque em uma apresentação o que se vê é "todo mundo uniformizado, bonito, todos os instrumentos novos, um maestro competente" (Suzana). Verificamos que a Semana Universitária torna-se um exemplo recorrente de opção de lazer, reforçando esta representação, exatamente porque os entrevistados reclamam da falta de espaços físicos destinados para esse tipo de atividade; a Fazenda Amália se constitui como o principal símbolo da cidade, pois parte dos seus moradores viveu nas casas construídas para os empregados, trabalhou nas indústrias Matarazzo e atualmente acompanha a destruição do que sobrou e, por fim, a Folia de Reis é vinculada aos lugares nos quais ela ocorre e às suas vestimentas. Discursivamente, não separam os sentimentos que possuem e o aspecto material de cada bem.

Ao lembrar-se do tempo em que estudou na fazenda, Boniperti constrói uma narrativa como se sua própria memória estivesse sendo destruída junto com a escola que frequentou, mostrando a inter-relação entre ambas: "Eu estudei a primeira série na escola de Amália, no grupo de lá. Só ficou a parede da frente e, segundo consta, informações confiáveis, não tinha uma goteira no prédio todo. (O prédio) estava perfeito e destruíram, foi ao chão. Eu tenho muitas lembranças daquela primeira série lá, tenho muita lembrança, e está no chão". Portanto, empiricamente, não se sustenta a rigidez da separação entre patrimônios culturais tangíveis e intangíveis, mas como tal divisão se estabeleceu historicamente nas políticas culturais, favorecendo a materialidade do bem, a concepção ainda dominante de patrimônio é aquela que o considera um conjunto restrito de coisas (arquitetura, obras de arte, sítios arqueológicos), como se seus valores fossem intrínsecos e evidentes.

Partindo dessa observação, acreditamos que o desenvolvimento da ideia de patrimônio imaterial permitiu não apenas uma ampliação dos bens passíveis de serem preservados pelas 
instituições e Estados nacionais, mas reformulou a própria noção de patrimônio cultural, possibilitando, entre outras coisas, uma maior participação da população nas decisões sobre o que deve ser valorizado e de qual maneira.

\subsection{A ideia de patrimônio}

Reconhecendo tal amplitude e os riscos de se utilizar um sentido restrito de patrimônio, as próprias resoluções recentes da UNESCO e Estados nacionais tem reafirmado a inter-relação entre materialidade e imaterialidade. Castelos, igrejas, obras de arte são classificados como patrimônios e vistos como diferentes das demais construções a partir dos significados que adquiriram socialmente, ou seja, seu caráter intangível. Ao mesmo tempo, o patrimônio intangível está imerso em um universo material, que é utilizado como suporte e símbolo para a sua perpetuação. Uma festa típica, por exemplo, só se realiza a partir de uma indumentária, de uma localização específica, de objetos ditos especiais ou sagrados.

Como sublinha Oliven (2003, p. 79), não há diferenças químicas entre a água benta e a água comum, um pedaço de tecido e uma bandeira, mas eles são tratados diferentemente pela carga simbólica adquirida na sociedade. Portanto, nesses casos, não é o suporte que justifica um bem ser visto como patrimônio cultural, mas os valores atribuídos a ele, apesar dos objetos merecerem ser preservados por constituírem um elemento do ato considerado intangível.

Para Smith (2008, p. 3), o ideal seria abandonarmos essa oposição e considerar todo patrimônio como intangível. Não que a autora negue o aspecto material de um bem, mas entende que ele não é autoexplicativo/ evidente e só se destaca dos demais materiais iguais ou semelhantes a partir dos sentidos que lhes são atribuídos nos seus usos sociais. Sua concepção, da qual compartilhamos, define o patrimônio como um processo social e cultural, um ato de comunicação e de atribuição de significados no e para o presente (SMITH, 2008, p. $1)$.

Deste modo, para reconhecê-lo e justificar seu status, devemos estudar os processos de rememoração e as representações sociais que o constrói discursivamente. Assim, considerando-o a partir do presente, o patrimônio desnaturaliza-se, torna-se resultado de seu tempo, passível de ser transformado conforme a instabilidade da memória e interesses políticos.

Para garantir que não apenas a memória dos grupos dominantes seja legítima, refuta-se a ideia de consenso nacional ou memória coletiva do discurso patrimonial autorizado em 
favor da noção de diversidade e entrelaçamento. Nesse sentido, acompanhamos Assmann (2007, p. 147) quando, utilizando principalmente as críticas de Pierre Nora a Maurice Halbwachs, defende que não existe uma memória de grupo como uma "alma coletiva" ou "espírito objetivo", mas através de um sistema de signos e símbolos, os indivíduos participam de uma memória no grupo, aberta à contestação e a negociação.

Em um mesmo espaço podem existir patrimônios que se contrapõem, que buscam escrever a história por meio de pressupostos que se anulam, mas que não deixam de ser legítimos, pois referem-se ao ponto de vista, sempre em construção, de determinada comunidade. O mesmo é válido para a questão da escala. Em nossa pesquisa, trabalhamos com o significado de obras para moradores de uma pequena cidade do interior do Estado de São Paulo. Aquilo que apresentamos como um símbolo local pode ser desconhecido pela maioria dos habitantes da região, entretanto, não o diminui em importância, pois não partimos de uma noção de consenso e unidade interpretativa. Entendemos que quanto mais próximo daqueles que sustentam os valores de um bem, mais se percebe que não há unanimidade e estabilidade, o que, na maioria das vezes, não é considerado na construção dos patrimônios nacionais.

Uma crítica aos que utilizam essa perspectiva é que, ao considerarmos a mudança e a representação social na identificação de patrimônios culturais, eles sempre serão circunstanciais e efêmeros, não justificando todos os instrumentos para sua proteção e promoção. Contudo, ao se transformarem e perderem os valores iniciais atribuídos por um grupo, esses bens não deixam de ser representativos em relação à história e a arte. É o que tem defendido o Brasil ao manter o registro e toda a documentação de uma obra mesmo quando ela não mais possui o título de patrimônio cultural nacional, porque é uma referência para compreender aqueles que a valorizava e seu tempo.

Desde 1992, com o programa Patrimônio Cultural Intangível, a UNESCO tem buscado não instituir políticas que "cristalize" e "engesse" esses bens, impedindo sua transmissão e adequação de acordo com os critérios de seus praticantes (AIKAWA, 2004, p. 139). Desta forma, admite-se que o foco nos processos de significação e não na materialidade de uma obra obriga abrir mão de um discurso tecnicista e unilateral em privilégio de um diálogo com a sociedade, no intuito de compreender suas expressões culturais.

$\mathrm{Na}$ mesma linha, Dicks (2000) apresenta o patrimônio como uma prática comunicativa. Através de um estudo de caso sobre o Rhondda Heritage Park, um parque/ museu ao ar livre em South Wales, Inglaterra, construído para divulgar a história do vale local de mineração de carvão, a autora reconstrói toda a polêmica envolvendo imprensa, 
autoridades e população em torno da mensagem que o lugar estava produzindo sobre a região, que para alguns tendia para o Disney-style. Com a aplicação de entrevistas em grupos de visitantes, a pesquisa buscou decifrar como estes imaginavam os moradores locais a partir da exposição no intuito de verificar se confirmavam os receios apresentados. O resultado, muito diferente da passividade prevista pelos críticos, foi que os visitantes reconheciam os esforços dos mineradores na luta por melhores condições de trabalho e vida, ao mesmo tempo em que alguns questionavam a neutralidade do museu em expor os fatos e as memórias desses trabalhadores. Assim sendo, sustenta-se que o patrimônio não deve ser explicado sem considerar as interpretações sociais, inclusive em suas contradições, através de um circuito comunicacional de codificação-decodificação.

Se há um sentido de negociação, também não podemos deixar de analisar o patrimônio como um processo pelo poder. Segundo Smith (2008), também observado por Canclini (1998, p. 205), é em um embate de forças que construímos aquilo que chamamos de a identidade coletiva, o que permitiu que mulheres, indígenas, operários, entre outras classes subalternas fossem excluídas das políticas culturais e do mercado dos bens simbólicos. Deste modo, um dos objetivos de uma revisão política e conceitual no campo patrimonial foi abranger o escopo daquilo que pode ser valorizado e estabelecer mecanismos que não beneficiassem apenas uma parcela da população. Na Convenção sobre a Proteção e Promoção da Diversidade das Expressões Culturais ${ }^{38}$, de 2005, por exemplo, um dos princípios diretores é que

a proteção e a promoção da diversidade das expressões culturais pressupõem o reconhecimento da igual dignidade e o respeito por todas as culturas, incluindo as das pessoas pertencentes a minorias e as dos povos indígenas (UNESCO, 2005, p. $3)$.

No entanto, mais que a elaboração de um conceito inclusivo, as discussões contemporâneas tem questionado a própria validade do entendimento do patrimônio como coisa, já que ao reduzi-lo a algo manejável, localizável, imutável, objetivo, exclui-se toda a dinâmica cultural, social e histórica que o produziu (SMITH, 2008, p. 31). Como algo neutro e asséptico, pronto a ser avaliado por técnicos em seus gabinetes, o bem deixa de exercer a

\footnotetext{
${ }^{38}$ Segundo Alves (2009, p. 178), a Convenção sobre a Proteção e Promoção da Diversidade das Expressões Culturais tomou com base e documento preparatório a Declaração Universal sobre a Diversidade Cultural. Nesse sentido, o autor considera a Declaração e a Convenção como resultado de um mesmo processo de quatro anos de duração.
} 
função de rememoração, identificação e ação social, como previsto pela nossa própria Constituição Federal de 1988.

A dificuldade para superar a concepção dominante, principalmente no senso comum, evidencia-se ao verificarmos que os discursos patrimoniais estão inseridos em um contexto de objetificação cultural, que consiste em uma tendência da cultura ocidental em imaginar fenômenos não materiais, como tempo, nação e tradição, como se fossem objetos físicos, desconsiderando que estes não existem a priori e nem são naturais, mas inventados pelas relações humanas (HANDLER, 1984, p. 55).

No Brasil, Gonçalves (2002) mostra essa ação nos discursos de Rodrigo Mello Franco de Andrade e Aloísio Magalhães, ex-presidentes do atual Instituto do Patrimônio Histórico e Artístico Nacional, que constroem e divulgam o patrimônio nacional como algo espontâneo e pré-existente, não resultado de interesses políticos e pessoais. Nesta perspectiva, "a nação, em ambas construções discursivas, é apresentada como um entidade dotada de coerência e continuidade", mas, para Gonçalves, antes de um "dado ontológico", essa coerência é apenas uma estratégia narrativa (ABREU, 2005, p. 39).

Uma das consequências da objetificação é que atribuímos a objetos a capacidade de representar relações sociais, ignorando os discursos que os produziram. Neste sentido, construções, fotografias, objetos validam o real, criando a ilusão de que a matéria é autoexplicativa (GONÇALVES, 2002, p. 29). Outra é que esses objetos são descontextualizados e reinterpretados, mas continuam, discursivamente, sendo considerados como uma ligação com o "passado autêntico" (HANDLER, 1984, p. 62).

Quando perguntamos aos entrevistados o que eles entendiam por patrimônio cultural ou se Santa Rosa possuía bens que se enquadravam em suas definições, observamos que alguns reproduzem o conjunto de objetos geralmente apresentado por essas políticas de reificação:

Entrevistador: O que você pensa quando ouve as palavras "patrimônio cultural"? Romeu: São prédios mesmo, fotografias, as composições musicais guardadas aí... Suzana: Um local que abriga uma história importante (...)

Entrevistador: Você acha que Santa Rosa possui patrimônios culturais? André: Sim, cultural e histórico. A cadeia velha, a Estação da Cultura, esse prédio aqui onde já foi escola são patrimônios. Omar: Sim, os prédios antigos, alguns pontos geográficos...

Maurílio: Construção muito pouca coisa, só mesmo isso que a Fundação apoia. 
Contudo, quando questionados sobre a sua relação com a cidade, seus símbolos e o que merece ser lembrado pelo setor cultural e pelos demais moradores, não são obras da arquitetura que se destacam, nem o valor histórico de uma construção. O que enfatizam é o processo que permitiu determinados bens serem vistos como representantes de uma cultura local. Utilizam a história para legitimá-los, mas defendem sua valorização pelo papel que exercem ou poderiam exercer na atualidade, mostrando que uma promoção só se justifica a partir do presente, como na ideia de reformular a SUSA ou transformar a Fazenda Amália em um museu.

Reafirmam o discurso patrimonial autorizado quando se expressam em âmbito abstrato e conceitual, mas o refutam ao identificar o que é memorável e identitário. Por exemplo, visitariam a fazenda Amália com um visitante não devido à sua arquitetura, mas porque foi ali que "nasceu" a cidade (Cheyenne), por ser um polo industrial construído pela família Matarazzo (Omar) e por representar o modo de vida do trabalhador rural (Boniperti). Os vestígios materiais são utilizados para validar seus discursos, mas os interpretam a partir de experiências individuais, permitindo que a fazenda ou qualquer outra construção seja vista por diferentes perspectivas.

Já quando analisamos o "discurso patrimonial autorizado" no Ocidente, verifica-se a defesa de uma ideia de estabilidade, a possibilidade de atingir um consenso, não considerando a dissonância e os conflitos em torno de um bem. Ao dizer que um patrimônio cultural é nacional ou mesmo mundial, transmite-se a mensagem que ele é a representação da nação ou, ironicamente, do mundo, ao invés de apenas localizá-lo espacialmente e defender que sua salvaguarda deva ser realizada em determinado nível. Um exemplo de dissonância é o Santuário do Órix em Omã, Península Arábica. Inscrito como patrimônio mundial em 1994 por ser uma região biogeográfica com plantas endêmicas e de rara fauna, foi retirado da lista em 2007 quando o governo nacional, contrariando as recomendações de preservação da UNESCO, decidiu diminuir a área protegida em 90\%. No mesmo sentido, poderíamos questionar o consenso em torno da classificação, em 2002, do minarete de Djam, no Afeganistão, como patrimônio mundial, mesmo pelo seu reconhecido valor histórico (construído no século XII), quando países discutem a proibição de construções desse tipo na Europa $^{39}$.

\footnotetext{
${ }^{39}$ Desde 2009 , por decisão popular (57\% da população em um referendo), está proibida a construção de minaretes em toda a Suíça. Política similar também tem sido defendida por representantes da direita na França, Bélgica e Alemanha.
} 
Considerando essas contradições, o patrimônio cultural, seja no senso comum como nas políticas oficiais, revela-se uma construção simbólica que garante que determinadas obras sejam preservadas, reconhecidas e divulgadas, podendo ser uma ação positiva para a sociedade se não impedir a coexistência de diferentes pontos de vista e se as políticas adotadas auxiliarem na continuidade de um bem a partir dos interesses dos seus responsáveis, sem enfraquecer as demais.

Em alguns casos, quando uma comunidade não solicita ou considera desnecessário um auxílio externo para promover sua cultura, a única atividade realizada por essas instituições patrimoniais deve ser o acompanhamento e registro de suas práticas, pois é de interesse somente daqueles "de fora" conhecer sua dinâmica e funcionamento.

Quando ao valor histórico e artístico é acrescentado o cultural, entende-se que a identificação de um bem passou pelo reconhecimento dos seus usos locais. Como dizer que ele é um patrimônio cultural se não é assim visto na cultura onde foi elaborado/ construído? Não que os grupos sociais que o mantêm devam antes classificá-lo nominalmente como patrimônio cultural e submetê-lo aos mesmos processos realizados por esses especialistas/ instituições, como isolamento, exposição, divulgação, mas que tenham atribuído um valor simbólico que o diferencie das demais obras, permitindo sua transmissão para as próximas gerações.

Como afirma Gonçalves (2003, p. 22-23), a definição de patrimônio geralmente utilizada, tão delineada e exata, constitui-se apenas no final do século XVIII, com a Revolução Francesa e a formação dos Estados Nacionais. No entanto, desde as sociedades tribais podemos encontrá-lo como uma categoria de pensamento, quando sociedades humanas já retinham e colecionavam bens para demarcar um domínio subjetivo. Estes podiam inclusive permanecer com funções práticas, mas também adquiriam finalidades religiosas, mágicas e sociais que permitiam a manutenção de relações consistentes mesmo quando esses objetos eram distribuídos ou destruídos, como nas sociedades Kula trobriandês e potlatch nos Estados Unidos.

Antes de atermos a uma definição restrita de patrimônio, devemos lembrar que a palavra patrimônio deriva dos vocábulos latinos pater e monium, formando patrimonium. Pater significa pai, não apenas no sentido de paternidade física, mas também social e religiosa, como algo que é transmitido e herdado dos antepassados. Já monium indica condição, estado, função. Deste modo, patrimônio se refere aos bens que são passados de geração em geração, sejam as riquezas herdadas como os saberes e costumes adquiridos. Apesar de estar relacionado com a ideia de propriedade, o patrimônio não se resume apenas 
ao que é material, mas a tudo aquilo que permaneceu ao longo do tempo entre os grupos e gerações.

Se não desejarmos apenas repetir o que foi instituído pelos Estados nacionais para a sustentação de determinadas representações, é necessário não considerar as sociedades humanas e suas culturas apenas como objetos a serem descritos e analisados, mas instituir mecanismos de diálogo, mediação para que quando um bem for nomeado patrimônio cultural pelas instituições responsáveis, beneficie, ou, no mínimo, não prejudique os propósitos dos sujeitos que o produziram. Identificado pela lógica dos seus realizadores, ele pode inclusive ser submetido aos instrumentos privilegiados por essas diferentes legislações e recomendações oficiais enquanto benéficos e complementares aos interesses locais.

Segundo Abreu (2003, p. 41), essa reformulação realizou-se devido a duas mudanças significativas que se sedimentaram no campo patrimonial, em nossa opinião, a partir do último quarto do século $\mathrm{XX}$ : a organização da sociedade civil e a afirmação do conceito antropológico de cultura. Com uma maior divulgação e possibilidade de acesso às informações referentes às políticas culturais, inclusive pela Internet, cada vez mais, a sociedade civil tem acompanhado e participação das decisões sobre o registro de um bem como patrimônio cultural. Ao mesmo tempo, a utilização do conceito antropológico de cultura, que privilegia os processos sociais pelos quais os homens significam e interpretam o mundo e a si mesmos, obriga que a análise de um bem considere os sentidos atribuídos e sustentados pelo grupo social, já que nesta perspectiva não é mais possível um discurso universalista. Por conseguinte, seja por pressões externas como pelo referencial teórico utilizado, a população tem conseguido participar de forma mais ativa das decisões oficiais, na medida em que essas concepções foram adotadas, a partir da década de 1970, nos planos políticos e jurídicos da UNESCO (ALVES, 2009, p. 177).

Em 2009, por exemplo, o processo para o registro do Toque dos Sinos em Minas Gerais como patrimônio cultural imaterial brasileiro iniciou-se com o pedido, por meio de um abaixo assinado, dos moradores de São João Del-Rei, em uma conferência com o Secretário de Cultura de Minas Gerais da época e membro do IPHAN. Durante o processo, apoios e anuências de várias instituições civis e públicas, como associações de amigos, foram incluídas ao processo e utilizadas para o parecer final, o que garantiu, mesmo com a toda a pesquisa sendo dirigida por especialistas, como antropólogos e historiadores, considerar os valores e sentidos atribuídos pela população (BRASIL, 2009). 
Essas noções simples favorecem o entendimento de que a preservação de um aglomerado de bens (tangíveis ou intangíveis) não constitui por si só um patrimônio. É preciso que tanto o remetente quanto o destinatário dessa prática social reconheçam e agreguem valores a esse mesmo aglomerado de bens, que poderá ser transmitido de uma geração para outra (perspectiva diacrônica), como também poderá ser partilhado numa mesma geração (perspectiva sincrônica) (CHAGAS, 2003, p. 97).

Neste sentido, buscamos nos exemplos citados no capítulo anterior, que são a Banda Sinfônica de Santa Rosa de Viterbo, a Semana Universitária Santa-rosense, a Fazenda Amália e a Folia de Reis, assinalar a construção de bens culturais representativos a partir das relações simbólicas existentes entre seus agentes, o que envolve a materialidade de cada bem, facilitando ações discursivas e comunicativas, mas que não se resume a ela. Mesmo, em alguns casos, os entrevistados não denominando tais bens como patrimônios culturais, atribuem a estes uma carga identitária e mnemônica, um sentido de expressão da cultura local, que os vinculam a esse conceito quando consideramos sua etimologia e algumas discussões contemporâneas. Portanto, se ainda não são referenciados como patrimônios culturais por uma perspectiva oficial, os são como uma categoria de pensamento.

Se compreendermos que os objetos pertencentes ao patrimônio também são documentos, pois desde Paul Otlet (1996) a Ciência da Informação considera, de uma maneira geral, documento qualquer objeto informativo, a perspectiva que adotamos permite-nos inclusive revisar a postura da CI perante esses objetos, pois a área faz uma separação entre estes e os processos que os possibilitaram.

Segundo Ortega e Lara (2010), a função da Ciência da Informação é produzir documentos (registros) a partir desses documentos primários (a obra em si), realizando uma mediação entre "objetos potencialmente informativos e pessoas potencialmente usuárias da informação". Reconhecendo que determinadas obras são informativas para a sociedade, caberia à Ciência da Informação documentá-las, divulgando e permitindo o acesso ao material produzido por meio de práticas documentárias.

Visão similar é a de Buckland (1991) ao analisar a informação "como coisa". Ao contrário da crítica que desenvolvemos ao longo do texto, o autor não sugere que os objetos podem ser informativos por uma característica inata, própria, mas defende que qualquer um pode ser um documento se receber esse atributo pela sociedade, concordando com sua condição potencial e circunstancial. A sua argumentação é que a Ciência da Informação lida apenas com objetos, como representações físicas de eventos e fenômenos, pois é a única forma passível de ser tratada pelos sistemas informacionais. 
Uma característica chave da "informação-como-conhecimento" é que ela é intangível: não se pode tocá-la ou medi-la de forma direta. Conhecimento, crença e opinião são pessoais, subjetivos e conceituais. Portanto, para comunicá-los, eles devem ser expressos, descritos ou representados em algum meio físico, como um sinal, texto ou comunicação. Qualquer forma de expressão, descrição ou representação seria “informação-como-coisa” (BUCKLAND, 1991, p. 351, tradução nossa).

Assim sendo, um problema surge quando analisamos essas práticas sobre o patrimônio cultural, pois se o consideramos um processo que também produz objetos materiais representativos simbolicamente, caberia à CI documentá-los e divulgá-los enquanto documentos. Entretanto, como discutimos e o próprio conceito de documento adotado pela CI sugere, a informatividade de uma obra é elaborada por práticas e discursos, de forma circunstancial e temporal, o que sempre a relativiza. Desta forma, como seria possível produzir documentos secundários a partir de obras consideradas patrimoniais sem considerar os significados que as permitiram serem vistas como tais ${ }^{40}$ ?

A Ciência da Informação reconhece que todo objeto está imerso em uma rede de sentidos, mas reproduz a divisão material-imaterial ao privilegiar a "informação-como-coisa". É como se fosse possível extrair e isolar um objeto das relações sociais que o produziram, alcançando um estado de objetividade que permitisse descrevê-lo, classifica-lo e divulga-lo. Em contrapartida, defendemos, nesta dissertação, a impossibilidade de divisão do objeto documental enquanto materialidade de um lado e construção social imaterial do outro, e ao invés da dicotomia "informação-como-conhecimento" e "informação-como-coisa", acreditamos que toda informação/objeto é, indissociavelmente, "conhecimento-e-coisa".

Por exemplo: um cientista da informação que trabalha em um museu sobre a cultura africana recebe um vaso que precisa ser descrito, classificado e exposto para o público. Se fossem restringir os processos documentários a apenas sua tangibilidade, as únicas informações disponíveis seriam que este vaso é de argila, tem um formato oval e foi decorado com duas cores. Deste modo, ele não diferiria de milhões de outros vasos com as mesmas características. O que o cientista da informação necessita identificar é o conhecimento que este objeto produz, ou seja, a sua intangibilidade, inserindo-o no contexto da cultura africana

\footnotetext{
${ }^{40}$ Segundo Dodebei (2000), não há objetos que são a priori informativos e outros não, mas todos os são potencialmente, a partir do momento em que reconhecemos que esta é uma atribuição construída através dos usos e contextos nos quais cada objeto está inserido. Nesse sentido, um prédio, um vaso, uma bandeira podem ser vistos como documentos pela área se, em uma perspectiva social, forem entendidos como construções que informam sobre algo, como, por exemplo, sobre um período, um grupo de pessoas, uma região, justificando sua valorização e preservação ao longo do tempo.
} 
da qual ele é proveniente, estabelecendo relações com os outros objetos da coleção e produzindo codificações para o público alvo do museu. Por conseguinte, este profissional, além de tratar o vaso como matéria, também o considera um emissor de significados passível de múltiplas decodificações pelo observador, em uma situação na qual ele não detém o controle interpretativo. $\mathrm{O}$ exposto não será apenas o objeto, mas informações de uma cultura que extrapolam os limites de sua materialidade.

Segundo Le Coadic (2004, p. 12), as disciplinas que atuaram no campo da informação, que para ele são a Biblioteconomia, a Museologia, a Documentação e o Jornalismo, priorizaram o suporte da informação e não a informação em si, dando pouca ou nenhuma ênfase para as relações de interpretação e uso que ocorrem dentro e fora das instituições informacionais. Diferentemente, a função da CI seria o estudo "das propriedades gerais da informação (natureza, gênese, efeitos) e a análise de seus processos de construção, comunicação e uso" (LE COADIC, 2004, p. 25). Contudo, como tais transformações não são automáticas e existe um intervalo entre o que é defendido na literatura e realizado na prática, discussões e ações a partir do caráter circunstancial, temporal e comunicacional dos bens culturais têm se limitado a outras disciplinas, como a Antropologia e Sociologia.

$\mathrm{Na}$ Ciência da Informação, o maior avanço foi o movimento conhecido como Nova Museologia. Em 1972, a partir de uma mesa-redonda realizada em Santiago, Chile, pesquisadores e museólogos apresentaram as bases para uma revisão do fazer museológico e o estabelecimento de uma nova relação entre o museu e a sociedade. De acordo com Santos (2008, p. 83),

\begin{abstract}
Em Santiago, é dado o pontapé inicial para uma ação museológica que considera o sistema linguístico empregado pelas comunidades, reconhece que o ser humano se move em um mundo essencialmente simbólico e compreende que o cotidiano não é apenas um resíduo. A vida cotidiana passa a ser considerada entre as múltiplas realidades, como "a realidade por excelência", que não se esgota na presença imediata, mas abarca fenômenos que não estão presentes "aqui e agora", o que significa que a experimentamos em diferentes graus de aproximação e distância, espacial e temporal.
\end{abstract}

Pela Nova Museologia, adota-se um novo conceito de patrimônio, definido como "patrimônio global" ou "patrimônio integral" em oposição à visão tradicional que não o considera em sua totalidade, ou seja, na relação entre o material e o imaterial, entre as práticas documentárias e os usos sociais nas suas mais variadas dimensões espaço-temporais. "Nesse sentido, as ações museológicas não serão processadas somente a partir de objetos, das 
coleções, mas tendo como referencial o patrimônio global" (SANTOS, 2008, p. 94). Assim, compreendendo o patrimônio como um processo comunicativo, os patrimônios são construídos e constantemente reformulados na interação e diálogo entre a experiência social e os critérios estabelecidos por instituições autorizadas, como os museus, em um movimento contínuo.

Como aponta Meneses (1994, p. 12), ao discutir a exposição museológica em museus históricos, "os artefatos [...] são não apenas produtos, mas vetores de relações sociais", o que exige não somente "identificar quadros materiais de vida, listando de objetos móveis, passando por estruturas, espaços e configurações naturais, até obras de arte", mas "entender o fenômeno complexo da apropriação social de segmentos da natureza física”.

Deste modo, não faz sentido uma separação entre patrimônio tangível e intangível ou objeto e processo, pois ele só se explica nesta relação, o que obriga qualquer ato documentário ir além da descrição dos produtos ou documentos originais de uma manifestação cultural e considerar os processos que garantiram sua produção. Caso contrário, a CI corre o risco de fetichizar os documentos ao invés de problematizá-los, o que nos faz concordar com a resposta de Meneses (1994, p. 27) quando pergunta como desfetichizar o objeto na exposição: "simplesmente trilhando o caminho inverso da fetichização, isto é, partindo do objeto para a sociedade".

No entanto, infelizmente, esta perspectiva, na CI, tem se restringido a alguns estudos museológicos, não atingindo outras práticas e ações da área. Ainda, considerando que grande parte dos princípios da Ciência da Informação são originários ou estão fortemente relacionados à Biblioteconomia, que historicamente esteve mais preocupada com os suportes informacionais do que com a própria informação (LE COADIC, 2004), o universo simbólico do patrimônio cultural e as experiências sociais que garantem a sua construção e preservação tem alcançado apenas um papel secundário nos processos documentários realizados pelas instituições informacionais.

Por isso, acreditamos que, apesar de não ser o objetivo final da CI, que seria produzir novos documentos, o estudo dos chamados documentos iniciais é essencial para que os processos documentários não naturalizem, no sentido de objetificação, os patrimônios culturais, ou pior, como acontece na maioria das vezes, validem a ideia de que os patrimônios são os próprios objetos ou suportes que eles produzem e necessitam para a sua realização e continuidade.

Em um momento em que a noção de patrimônio é revisada a partir da constatação dos limites das definições ainda dominantes, a contribuição da Ciência da Informação, que 
participa das ações institucionais que legitima um bem cultural principalmente pela sua documentação, pode ser a de desconstruir, em diálogo com outras disciplinas, as práticas que classifica uma obra como informativa de uma cultura, através da análise de suas instituições, dos meios pelos quais essa obra é "socialmente disciplinada", da sua contingência histórica e dos seus discursos/ enunciados ${ }^{41}$ (FROHMANN, 2004, 2008).

\footnotetext{
${ }^{41}$ A contribuição de Frohmann é o desenvolvimento de uma discussão sobre a materialidade da informação, não no sentido de fisicalidade como utilizamos no texto e está presente nos documentos patrimoniais, mas na concepção foucaultiana de enunciados. Desta forma, seu objetivo é compreender o seu surgimento, regras e relações, ou seja, sua existência (FROHMANN, 2008, p. 22).
} 


\section{CONSIDERAÇÕES FINAIS: UM OLHAR SOBRE AS ESCALAS}

Em tempos de globalização, a abordagem pós-moderna argumenta que vivemos um processo de homogeneização social e econômica. Por velozes meios de comunicação e transportes, compartilhamos produtos, serviços, emoções, expectativas com pessoas de todos os cantos do planeta, resultando na dissolução do local no global e o abandono do espaço para o "território em rede" (BOURDIN, 2001, p. 60).

Nesta perspectiva, "a relação proximidade/ distância perde todo significado e, dessa forma, a proximidade não tem mais sentido" (BOURDIN, 2001, p. 14). Um indivíduo pode não conhecer sua vizinhança e pertencer a uma rede social na Internet; não frequentar um bairro de sua cidade, mas viajar anualmente ao exterior. A identidade e a cultura vinculada a uma localidade espacial é apresentada somente como um mecanismo de resistência ou fuga, incapaz de sobreviver a um mundo interconectado.

Evidentemente que com as transformações espaços-temporais é praticamente impossível descrevermos um lugar fechado em si próprio, não influenciado por fatores externos, mas nos propusemos a mostrar ao longo desta dissertação que o espaço ainda pode exercer um papel vital na vida dos moradores de uma cidade. Mais importante do que apontar uma oposição entre as ideias de local e global foi discutir que ambos podem coexistir e se complementarem, sendo considerados em uma análise que transita do cotidiano às estruturas mais gerais de uma sociedade.

Segundo Cunha (2000, p. 44), a Geografia, ao longo de sua história como disciplina, se dividiu em dois paradigmas que mostram à dificuldade de conciliação de ambas as escalas. A vertente positivista, dominante ainda no início do século $\mathrm{XX}$, valorizava a indução à dedução, reduzindo a escala ao regional pela crença que nele tudo poderia ser medido e visto. Já a vertente materialista, baseada em um quadro teórico-metodológico de dedução,

privilegiou a busca pela totalidade, produzindo explicações universais que desconsideravam as particularidades e diferenças. A consequência foi que ambas se mostraram ineficazes, seja por não conseguirem produzir uma explicação "lógico-dedutiva consistente" ou ignorar o que não se reduzia a regra geral.

Outra oposição se encontra na construção do conceito de lugar. Na Geografia clássica, o lugar se resumia a delimitação física do espaço, como algo que pode ser objetivamente 
medido e quantificado. A partir dos anos 80 do século passado, a influência do homem sobre o espaço ganhou importância, acrescentando à delimitação do lugar a subjetividade da cultura. Deste modo, sedimentou-se a divisão do espaço como distância entre dois pontos e o lugar como a junção do espaço mais a intervenção humana (HOLZER, 1999).

Para esta dissertação, escolhemos não eliminar nenhuma das escalas ou opor o território às experiências subjetivas, mas a partir das percepções sociais de um grupo de habitantes da cidade de Santa Rosa de Viterbo, refletimos sobre relações que sustentam os diferentes sentidos da categoria patrimônio. Observando a existência de leis, documentos oficiais e instituições que produzem e legitimam determinados conceitos de patrimônio cultural, procuramos discutir possibilidades interpretativas que não se restringem a profissionais e técnicos autorizados. Assim sendo, nos dirigimos a um grupo de pessoas não inseridas nesse quadro normativo para analisar a produção de sentidos sobre o que seja patrimônio a partir de práticas sociais.

Pela necessidade de delimitar um grupo de pessoas para participar e colaborar com a pesquisa, selecionamos um conjunto de moradores desta cidade por dois motivos. Primeiro, porque o pesquisador, como seu habitante, já possuía conhecimentos e meios prévios para contatar pessoas e acessar documentos que poderiam não ser disponibilizados em outras localidades, tornando a pesquisa viável. Segundo, porque como Santa Rosa não tinha um histórico de discussões sobre o seu patrimônio local, seja institucionalmente como pelos seus moradores, possíveis colaboradores não possuíam um quadro discursivo pré-formulado para falar sobre a cidade e seus bens culturais. Portanto, aumentavam as possibilidades de questionamentos que não se limitavam aos dizeres oficiais e que pudessem contribuir para uma revisão da ideia de patrimônio.

É verdade que os resultados obtidos neste contexto não podem ser, automaticamente, generalizados, pois partem de premissas diferentes. Enquanto um estudo empírico se baseia em uma realidade historicamente datada e espacialmente delimitada, a generalização é um procedimento de abstração e representação, reduzindo as particularidades e detalhes em favor de uma perspectiva global (LEPETIT, 2006, p. 87). No entanto, como ambas se relacionam, a partir de uma situação concreta podemos obter indícios que permitem pensar sobre diferentes noções, principalmente quando temos como parâmetro os seus usos.

Nesse sentido, buscamos pensar a realidade sobre a qual debruçamos também tendo como referência discussões anteriores realizadas em outras localidades e pelas instituições que regem essas políticas. Simultaneamente, propomos revisões sobre os conceitos teóricos a partir da observação de relações que diferem ou reformulam as abordagens geralmente 
privilegiadas. Como defende Levi (2009, 13), procuramos "chegar às generalizações sem descartas os indivíduos, as situações" e "descrever situações, pessoas [...] sem renunciar à compreensão dos problemas gerais".

Os estudos existentes sobre o patrimônio cultural foram produzidos, de maneira geral, a partir de uma perspectiva nacional, desfavorecendo a valorização de sentidos pertencentes a grupos excluídos e restritos a determinadas regiões. Revezando a escala de análise, torna-se possível o conhecimento de visões periféricas que não são consideradas quando as verificamos em um contexto muito amplo. Desta forma, a partir de ângulos que são entendidos como secundários, encontramos leituras sociais que podem questionar a compreensão dominante.

Um ponto importante da nossa pesquisa é que, além de desenvolver uma discussão em uma perspectiva geral, conseguimos mapear e analisar um contexto específico, contribuindo diretamente para as questões patrimoniais em Santa Rosa. Ao utilizarmos os relatos de moradores, relacionamos o que a literatura construiu como relevante com aquilo que eles percebem e gostariam que acontecesse, verificando a validade das discussões teóricas para as atuais e possíveis ações culturais no município.

Isto não significa que quando os conceitos teóricos não se adéquam a realidade estudada estão equivocados ou são incompletos. Como sugerimos, a abordagem teórica e a prática, o macro e o micro possuem pressupostos, objetivos e resultados distintos. A decisão por um ou por outro depende do objeto e da finalidade de cada perspectiva e não da constatação de que um é, a princípio, mais apropriado do que o outro. Em nossa opinião, a utilização de diferentes escalas, técnicas e da interdisciplinaridade contribuiu para suavizar os limites de cada abordagem, mostrando que podemos encontrar complementaridade nas diferenças.

Como observou Elmir (2004, p. 196-197) a partir dos escritos de Ronaldo Vanifas, um dos riscos da microanálise é se fechar em um empiricismo que não consegue construir relações e analogias com outros contextos, diminuindo-a em relevância. Ao mesmo tempo, entendemos que a microanálise pode atingir um nível de abstração tão grande que a distancia de qualquer realidade, tornando-a inlocalizável no tempo e no espaço.

Assim sendo, tivemos como intuito relacionar os resultados da nossa observação local com as preocupações mais amplas sobre o patrimônio cultural, sem, contudo, fazer apenas uma transmutação de escalas. Preferimos utilizar características que se contrapunham como sinais para refletir e questionar as estruturas existentes, permitindo o desenvolvimento de uma 
ideia de patrimônio a partir de uma localidade específica tratada como possibilidade para novas abordagens.

Ao utilizarmos esses pressupostos, conseguimos mostrar o papel de um conjunto de indivíduos na construção de uma política cultural, mesmo que não formalizada, no município. Apresentando as realizações de pessoas como Maurílio de Oliveira e Omar Nagib, apontamos que ações individuais podem modificar ou transformar quadros estabelecidos por condições externas ao mesmo tempo em que elas não são totalmente independentes.

\begin{abstract}
A escolha de escala da microanálise é exatamente em função dos objetos analíticos propostos, isto é, as relações interpessoais: isso vale para os grupos sociais e para as comunidades. A opção pela segunda, que constitui o nexo de correspondência entre o agregado social e o espaço, é feita em função de uma mais completa reconstrução das estruturas de dependência internas, ainda que reconheça que se mantém em pé para este fim também a relevância crucial dos papéis de mediação com a sociedade externa. A fidelidade ao contexto tem um significado heurístico preciso: antes de tudo possibilita a reconstrução em termos dinâmicos da estrutura social que postula um sistema de papéis, e papéis inovadores, permitindo assim estudar concretamente a mudança social (GRENDI, 2009, p. 45).
\end{abstract}

Ao realizarmos um trabalho com referenciais da Ciência da Informação, Ciências Sociais, História à Antropologia Social, conseguimos desenvolver uma abordagem que se caracteriza mais pela construção de uma perspectiva interdisciplinar do que pela aplicação de pressupostos pré-definidos. Concomitantemente, as discussões produzidas sobre a escala da pesquisa contribuíram para refletirmos sobre o lugar que escolhemos para a sua realização.

Primeiro, definimos uma micro-recorte espacial, a cidade de Santa Rosa de Viterbo, para em seguida estabelecer um micro-recorte temático, o patrimônio cultural local, o que para Neves $(2008$, p. 33) correspondem às características dos objetos de estudo da história local e regional no primeiro caso e da micro-história no segundo. Contudo, ainda utilizamos técnicas da história oral para a realização das entrevistas e a ideia de representação social, amplamente criticada pelos estudos de micro-história por supostamente homogeneizar a sociedade ao contrário de sublinhar as diferenças entre os indivíduos.

Pela história oral, aplicamos entrevistas para compreender aquilo que pelos documentos disponíveis não era possível; a percepção dos moradores sobre o setor cultural municipal. Como citamos, Santa Rosa não possui um arquivo público e sua documentação é esparsa. Pelo o que conseguimos consultar e pela legislação, como a Lei no 3054 de 2006 que criou o Conselho Municipal de Preservação do Patrimônio, poderíamos supor que, a 
princípio, a cidade já tinha realizado algumas ações referentes ao seu patrimônio local, mas, no contato direto com alguns moradores e dirigentes, descobrimos que tais iniciativas eram ainda incipientes, sem resultados práticos. Desta forma, mais importante do que reconstruir as políticas oficiais, foi mapear as percepções, representações e desejos que circulam entre os habitantes desta cidade no que se refere aos seus bens culturais.

Quando falamos em representação, aparentemente, nos distanciamos daquilo que é conhecido como microanálise ou, mais especificamente, micro-história. Tal crítica existe, pois, na concepção durkheimiana, a representação social é um elemento de coesão, estabilidade e conservação das forças e estruturas da sociedade. Por conseguinte, qual a importância da escala se o indivíduo faz parte de um todo estável e indissociável? (DUVEEN, 2009, p. 14-15). No entanto, nossa concepção partiu do entendimento contemporâneo, como o desenvolvido por Serge Moscovici, que a define como um "sistema de valores, ideias e práticas" que ordena e classifica o mundo para a comunicação entre diferentes grupos, sem, contudo, negar a heterogeneidade e diversidade das representações e a possibilidade de resignificações em um movimento contínuo (DUVEEN, 2009, 15-21).

Assim, enquanto abordamos as características individuais de cada entrevistado, enfatizamos que suas opiniões participam de uma rede de compartilhamentos e relações, que ela é influenciada pelo contexto no qual está inserida e pela memória social. Essa necessidade foi reforçada pela importância que atribuímos ao lugar em nossa pesquisa. Ao conferirmos atributos em comum entre os entrevistados a partir da relação com o espaço onde vivem, entendemos que estes estavam interligados e que poderiam contribuir para a compreensão do cotidiano de moradores com histórico parecido.

Partimos do pressuposto de um espaço simbolizado e não absoluto (CARDOSO, 1998). Além de uma delimitação geográfica, analisamos Santa Rosa como um lugar onde se desenvolvem um conjunto de práticas e trocas simbólicas influenciadas por características espaciais. Desta maneira, situamos o modo de vida dos trabalhadores da Fazenda Amália como um dos princípios da configuração atual da zona urbana, pois laços estabelecidos anteriormente foram mantidos. Mesmo com a diversificação da população e um maior trânsito por outras regiões, transformando esses vínculos, eles não simplesmente desapareceram, mas o passado continuou a ser um parâmetro para o presente.

Como bem apresentou Anderson (2008) na formação das comunidades imaginadas, o território exerce um papel relevante na formação das identidades sociais. Ser brasileiro, paulista ou santa-rosense é um fator de reconhecimento, identificação e sociabilidade 
(principalmente quando se está fora do território), mesmo que as características individuais sejam díspares. Nesse sentido, uma abordagem local

[...] constitui-se [...] numa proposta de investigação das atividades cotidianas de comunidades conectadas historicamente num território, conscientes do pertencimento a ele, integradas [...] em afinidades territoriais, consanguíneas, políticas, culturais e econômicas, com a identificação das suas interações internas e articulações exteriores, na perspectiva da totalidade histórica, como meio de se alcançar o conhecimento de viveres e saberes em dimensões inatingíveis por outras abordagens sistemáticas ou de abrangências espaciais mais amplas (NEVES, 2008, p. 31).

Ao analisar os relatos dos moradores, mapeamos as diferentes relações e grupos aos quais pertenciam, não os isolando em apenas uma característica ou território. Um integrante da Banda Sinfônica também pode ser um ex-morador da Fazenda Amália ou um jovem desempregado (relações internas). Concomitantemente, pode cursar uma faculdade em Ribeirão Preto e visitar seus parentes na cidade vizinha de Cajuru (relações externas). O território se apresentou em suas sobreposições (SILVA, 2000), permitindo que em torno de um vínculo central, o patrimônio local, nós compreendêssemos uma diversidade de categorias interligadas.

Se a princípio Santa Rosa é apenas um recorte político-administrativo e geográfico, as relações estabelecidas neste espaço permitem que ela adquira um significado de unidade identitária para a população. Ao usarem, nas entrevistas, expressões como "não sou daqui” ou "fico pouco tempo aqui" para contextualizar suas opiniões, observou-se o papel que o território tem sobre suas percepções.

Se há uma organização espacial que destaca determinados bens e estabelece suas funções, privilegiamos seus usos e "contra-usos" (LEITE, 2007) para conhecer os valores atribuídos às construções e praticas culturais existentes em Santa Rosa. Assim sendo, discutimos o que é considerado um patrimônio cultural para os moradores locais, ou seja, quais os bens que, em suas opiniões, sintetizam uma concepção de identidade e memória social.

Por meio das experiências sócio-espaciais dos entrevistados e pelas reflexões teóricas produzidas sobre o patrimônio cultural, construímos uma ideia de patrimônio que não se restringe a oposição material-imaterial. Entendemos que a classificação de algo como patrimônio é resultado de um conjunto de significações elaboradas em sociedade, expressando 
seu caráter intangível. Ao mesmo tempo, todo bem apresenta um aspecto material, pois, mesmo em performances, existem objetos como indumentárias, esculturas e alimentos que garantem sua tangibilidade.

Desta forma, questionando o que chamamos de "discurso patrimonial autorizado", procuramos estimular os participantes da pesquisa a pensar sobre os elementos culturais que supostamente identificam Santa Rosa, exercendo, portanto, um papel crítico em relação às suas percepções e representações. Também analisamos os discursos e ações que produziram as ideias dominantes de patrimônio cultural, demonstrando que as discussões atuais têm aproximado as instituições e profissionais especializados dos usos sociais de um bem no intuito de assegurar sua legitimidade e continuidade.

Por último, ao mostrar que um mesmo bem cultural tem diferentes sentidos para diferentes pessoas, em diferentes situações e escalas, reforçamos a concepção de que é insuficiente considerar, para as políticas culturais, apenas os valores inicialmente a ele atribuídos pelos profissionais autorizados, pois a sociedade não apenas assimila esses valores, em uma transmissão unidirecional, mas, apropriando-os em sua vida cotidiana, os transformam de acordo com os seus sentimentos, memória e expectativa de futuro. 


\section{FIGURAS}

Fig 1: ABREU, Raphael Lorenzeto de. [Santa Rosa de Viterbo no Estado de São Paulo]. 2006. 1 mapa, color. Escala indeterminável. Disponível em:

$<$ http://pt.wikipedia.org/wiki/Ficheiro:SaoPaulo_Municip_SantaRosadeViterbo.svg $>$. Acesso em 03 nov. 2010.

Fig. 2: [Fazenda Amália na década de 1940 (I)]. [194?]. 1 fotografia, p\&b. Coleção particular Romeu Antunes.

Fig. 3: [Fazenda Amália na década de 1940 (II)]. [194?]. 1 fotografia, p\&b. Coleção particular Romeu Antunes.

Fig. 4: SOUZA, Willian E. R. de. Panorama parcial da cidade com a Igreja Matriz ao centro. 2009. 1 fotografia, color. Coleção particular.

Fig. 5: SOUZA, Willian E. R. de. Cartaz na entrada da cidade. 2009. 1 fotografia, color. Coleção particular.

Fig. 6: SOUZA, Willian E. R. de. Estação da Cultura. 2009. 1 fotografia, color. Coleção particular.

Fig. 7: [BANDA SINFÔNICA DE SANTA ROSA DE VITERBO]. [200?]. 1 fotografia, color. Disponível em: $<$ http://www.bandasinfonicasrv.com/index.php $>$. Acesso em: 20 jan. 2010 .

Fig. 8: BANDA DUMONT 1901. 1901. 1 fotografia, p\&b. Disponível em:

$<$ http://www.bandasinfonicasrv.com/nossas bandas.php $>$. Acesso em: 20 jan. 2010.

Fig. 9: BANDA GIUSEPPE VERDI 1926. 1926. 1 fotografia, p\&b. Disponível em: $<$ http://www.bandasinfonicasrv.com/nossas bandas.php $>$. Acesso em 20 jan. 2010.

Fig. 10: [FAZENDA AMÁLIA NO INÍCIO DO SÉCULO XX]. [19?]. 1 fotografia, p\&b. Coleção particular Romeu Antunes.

Fig. 11: SOUZA, Willian E. R. de. Sede da Fundação Cultural com a inscrição "Posto Policial" na fachada. 2010. 1 fotografia, color. Coleção particular.

Fig. 12: SOUZA, Willian E. R. de. Área externa da sede da Fundação Cultural. 2010. 1 fotografia, color. Coleção particular. 


\section{REFERÊNCIAS}

ABREU, Regina. "Tesouros humanos vivos" ou quando as pessoas transformam-se em patrimônio cultural - notas sobre a experiência francesa de distinção do "Mestre da Arte". In: ABREU, Regina; CHAGAS, Mário (Orgs.). Memória e patrimônio: ensaios contemporâneos. Rio de Janeiro: DP\&A, 2003a. p. 81-94.

A emergência do patrimônio genético e a nova configuração do campo do patrimônio. In: ABREU, Regina; CHAGAS, Mário (Orgs.). Memória e patrimônio: ensaios contemporâneos. Rio de Janeiro: DP\&A, 2003b. p. 30-45.

Quando o campo é o patrimônio: notas sobre a participação de antropólogos nas questões do patrimônio. Sociedade e Cultura, Goiânia, v. 8, n. 2, p. 37-52, 2005. Disponível em: < http://www.revistas.ufg.br/index.php/fchf/article/view/1010/1204>. Acesso em: 13 set. 2010 .

AIKAWA, Noriko. An historical overview of the preparation of the UNESCO International Convention for the Safeguard of the Intangible Cultural Heritage. Museum International: Intangible Heritage, Paris (UNESCO), v. 56, n. 1-2, p. 137-149, 2004. Disponível em: < http://unesdoc.unesco.org/images/0013/001358/135852e.pdf\#135853>. Acesso em: 13 set. 2010.

ALMEIDA JÚNIOR, Oswaldo Francisco de. Mediação da informação e múltiplas linguagens. In: ENCONTRO NACIONAL DE PESQUISA EM CIÊNCIA DA INFORMAÇÃO, 9., 2008, São Paulo. Anais eletrônicos... São Paulo: ENANCIB, 2008. Disponível em: < http://extralibris.org/2008/09/textos-integrais-dos-trabalhos-aprovados-no-ix-enancib/ >. Acesso em: 12 jun. 2009. Não Paginado.

ALMEIDA, Marco Antônio de. Mediação cultural e da informação: considerações socioculturais e políticas em torno de um conceito. In: ENCONTRO NACIONAL DE PESQUISA EM CIÊNCIA DA INFORMAÇÃO, 8., 2007, Salvador. Anais eletrônicos... Salvador: ENANCIB, 2007. Disponível em: $<$ http://www.enancib.ppgci.ufba.br/artigos/GT3-212.pdf >. Acesso em: 03 ago. 2008. Não Paginado.

AMARAL, Rita. O tempo de festa é sempre. NAU - Núcleo de Antropologia Urbana da USP, São Paulo, 1993. Disponível em: < http://www.n-a-u.org/Amaral-povodefesta.html>. Acesso em: 26 set. 2009.

ALVES, Elder Patrick Maia. O advento de uma nova formação discursiva: o repertório discursivo UNESCO. In: . A economia simbólica da cultura popular sertanejonordestina. 2009. 385 f. Tese (Doutorado em Sociologia)-Departamento de Sociologia, Instituto de Ciências Sociais, Universidade de Brasília, 2009. 
ANDERSON, Benedict. Comunidades imaginadas: reflexões sobre a origem e a difusão do nacionalismo. São Paulo: Companhia das Letras, 2008.

ANTUNES, Romeu J. Histórias de Santa Rosa de Viterbo. Santa Rosa de Viterbo: Ed. O Santa Rosa, 2000.

AQUINO, Cássio Adriano Braz; MARTINS, José Clerton de Oliveira. Ócio, lazer e tempo livre na sociedade do consumo e do trabalho. Revista Mal-estar e Subjetividade, Fortaleza, v. 7, n. 2, p. 479-500, set. 2007. Disponível em: < http://www.unifor.br/notitia/file/1851.pdf >. Acesso em 12 jan. 2010.

ARANTES, Antônio Augusto (Org.). Produzindo o passado: estratégias de construção do patrimônio cultural. São Paulo: Brasiliense, 1984.

ARGAN, Giulo Carlo. C. História da arte como história da cidade. 5. ed. São Paulo: Martins Fontes, 2005.

ARENDT, Hannah. Entre o passado e o futuro. 6. ed. São Paulo: Perspectiva, 2007.

ARFUCH, Leonor. O espaço biográfico na (re)configuração da subjetividade contemporânea. In: GALLE, Helmut et. al. (Orgs.). Em primeira pessoa: abordagens de uma teoria da autobiografia. São Paulo: Annablume; FAPESP; FFLCH, USP, 2009. p. 113-121.

ASSMANN, Aleida. Ricordare: forme e mutamenti della memoria culturale. Bologna: Il Mulino, 2007.

AUGÉ, Marc. Rovine e macerie: il senso del tempo. Torino: Bollati Boringhieri, 2004.

BACZKO, Bronislaw. Imaginário social. In: Enciclopédia Einaudi: Anthropos-Homem. Lisboa: Imprensa Nacional - Casa da Moeda, 1985. p. 296-332. (v. 5).

BARBERO, Jesus Martín. Memoria narrativa e industria culturale. La Ricerca Folklorica: cultura popolare e cultura di massa, San Zeno Naviglio, n. 7, p. 9-17, abr. 1983. Disponível em: $<$ http://www.jstor.org/pss/1479711 >. Acesso em: 24 mar. 2010.

BAUMAN, Zygmunt. Identidade: entrevista a Benedetto Vecchi. Rio de Janeiro: Jorge Zahar Ed., 2005.

BEDJAOUI, Mahammed. The Convention for the Safeguarding of the Intangible Cultural Heritage: the legal framework and universally recognized principles. Museum International: Intangible Heritage, Paris (UNESCO), v. 56, n. 1-2, p. 150-155, 2004. Disponível em: < http://unesdoc.unesco.org/images/0013/001358/135852e.pdf\#135853 >. Acesso em: 13 set. 2010 .

BENJAMIN, Walter. Magia e técnica, arte e política: ensaios sobre literatura e história da cultura. 7. ed. São Paulo: Brasiliense, 2008. (Obras escolhidas; v. 1) 
BLOCH, Marc. Apologia da história ou O ofício do historiador. Rio de Janeiro: Jorge Zahar Ed., 2001.

BOSI, Alfredo. História concisa da literatura brasileira. 44. ed. São Paulo: Cultrix, 2007.

BOSI, Ecléa. Memória e sociedade: lembrança de velhos. São Paulo: Companhia das Letras, 1994. 2003.

O tempo vivo da memória: ensaios de psicologia social. São Paulo: Ateliê Editorial,

BOURDIEU, Pierre; DARBEL, Alain. O amor pela arte: os museus de arte na Europa e seu público. São Paulo: Editora da Universidade de São Paulo: Zouk, 2003.

BOURDIN, Alain. A questão local. Rio de Janeiro: DP\&A, 2001.

BRANDÃO, Carlos Rodrigues. A participação da pesquisa no trabalho popular. In:

(Org.). Repensando a pesquisa participante. 3. ed. São Paulo: Brasiliense, 2001. p. 223 252.

BRASIL. Constituição (1988). Disponível em: <

http://www.planalto.gov.br/ccivil_03/constituicao/constitui\%C3\%A7ao.htm>. Acesso em: 28 ago. 2008.

Decreto $\mathrm{n}^{\mathrm{o}} 3.551$, de 4 de agosto de 2000. Institui o Registro de Bens Culturais de Natureza Imaterial que constituem patrimônio cultural brasileiro, cria o Programa Nacional do Patrimônio Imaterial e dá outras providências. Disponível em: < http://www.cultura.gov.br/legislacao/direitos_autorais/legislacao/index.php? $\mathrm{p}=1082 \&$ more $=1$ $\& \mathrm{c}=1 \& \mathrm{pb}=1>$. Acesso em: $17 \mathrm{de}$ dez. 2008.

. Decreto-lei $\mathrm{n}^{\mathrm{o}} 25$, de 30 de novembro de 1937. Organiza a proteção do patrimônio histórico a artístico nacional. Disponível em: $<$ http://www.planalto.gov.br/CCIVIL/DecretoLei/Del0025.htm>. Acesso em: 28 de ago. 2008.

. Lei $\mathrm{n}^{\mathrm{o}} 4.214$, de 2 de março de 1963. Dispõe sobre o Estatuto do Trabalhador Rural. Disponível em: < http://www6.senado.gov.br/legislacao/ListaPublicacoes.action?id=183976> . Acesso em: 13 set. 2009.

. Ministério da Cultura. Instituto do Patrimônio Histórico e Artístico Nacional. Parecer $\mathrm{n}^{\circ}$ 27/GR/DPI/Iphan, de 30 de setembro de 2009. Processo referente ao Registro d'O Toque dos Sinos em Minas Gerais, tendo como referência São João del-Rei e as cidades de Ouro Preto, Mariana, Catas Altas, Congonhas do Campo, Diamantina, Sabará, Serro e Tiradentes. Brasília, 2009. Disponível em: < http://portal.iphan.gov.br/portal/baixaFcdAnexo.do?id=1390>. Acesso em: 14 set. 2010.

BRIOSCHI, Lucila Reis. Caminhos do ouro. In: BACELLAR, Carlos de Almeida Prado; BRIOSCHI, Lucila Reis (Orgs.). Na estrada do Anhanguera: uma visão regional da história paulista. São Paulo: Humanitas: FFLCH/USP, 1999a. p. 35-54. 
Fazendas de criar. In: BACELLAR, Carlos de Almeida Prado; BRIOSCHI, Lucila Reis (Orgs.). Na estrada do Anhanguera: uma visão regional da história paulista. São Paulo: Humanitas: FFLCH/USP, 1999b. p. 55-89.

BUCKLAND, Michael K. Information as thing. Journal of the American Society for Information Science, v. 42, n.5, p.351-360, 1991. Disponível em: < http://people.ischool.berkeley.edu/ buckland/thing.html>. Acesso em: 17 ago. 2007.

CÂNDIDO, Antônio. A cultura caipira. [19?]. Disponível em: < http://www.widesoft.com.br/users/pcastro2/cultura.htm>. Acesso em: 9 mar. 2009.

Literatura e sociedade: estudos de teoria e história literária. 10. ed. Rio de Janeiro: Ouro sobre Azul, 2008.

Os parceiros do Rio Bonito: estudo sobre o caipira paulista e a transformação dos seus meios de vida. 10 ed. São Paulo: Duas Cidades; Ed. 34, 2003.

CAPRI, Roberto. O Estado de São Paulo e seus Municípios. São Paulo, TYP, Pocai \& Weiss, 1913. (v.3).

CARDOSO, Ciro Flamarion Santana. Repensando a construção do espaço. Revista de História Regional, Ponta Grossa, v. 3, n. 1, p. 7-23, 1998. Disponível em: $<$ http://www.revistas.uepg.br/index.php?journal=rhr\&page=article\&op=view\&path[] $=76>$. Acesso em: 15 dez. 2010.

CERTEAU, Michel de. A escrita da história. 2. ed. Rio de Janeiro: Forense Universitária, 2008 .

. A invenção do cotidiano: 1. artes de fazer. 10. ed. Rio de Janeiro: Vozes, 2004.

CHAGAS, Mário. O pai de Macunaíma e o patrimônio espiritual. In: ABREU, Regina; CHAGAS, Mário (Orgs.). Memória e patrimônio: ensaios contemporâneos. Rio de Janeiro: DP\&A, 2003. p. 95-108.

CHARTIER, Roger. A história ou a leitura do tempo. Belo Horizonte: Autêntica Editora, 2009.

CHAUÍ, Marilena. Política cultural, cultura política e patrimônio histórico. In: São Paulo (cidade). Secretaria Municipal de Cultura. O direito à memória: patrimônio histórico e cidadania. São Paulo: Departamento do Patrimônio Histórico, 1992. p. 37-46.

CHOAY, Françoise. A alegoria do patrimônio. 3. ed. São Paulo: Estação Liberdade; UNESP, 2006.

COELHO NETTO, José Teixeira. Dicionário crítico de política cultural. São Paulo: Iluminuras, 1997.

Usos da cultura: políticas de ação cultural. Rio de Janeiro: Paz e Terra, 1986. 
CORREIA, Telma de Barros. De vila-operária a cidade-companhia: as aglomerações criadas por empresas no vocabulário especializado e vernacular. Revista Brasileira de Estudos Urbanos e Regionais, Recife, ano 3, n. 4, p. 81-96, maio 2001. Disponível em:

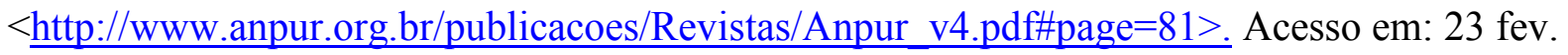
2009.

COUTO, Ronaldo Costa. Matarazzo: a travessia. São Paulo: Editora Planeta do Brasil, 2004a.

Matarazzo: colosso brasileiro. São Paulo: Editora Planeta do Brasil, 2004b.

CRUIKSHANK, Julie. Tradição oral e história oral: revendo algumas questões. In: FERREIRA, Marieta de Moraes; AMADO, Janaína (Orgs.). Usos \& abusos da história oral. 2. ed. Rio de Janeiro: Fundação Getúlio Vargas, 1998. p. 149-164.

CUNHA, Claudia dos Reis e. Alois Riegl e "O culto moderno dos monumentos". Revista CPC, São Paulo, v. 1, n. 2, p. 6-16, maio/ out. 2006. Disponível em: < http://www.usp.br/cpc/v1/imagem/conteudo_revista_arti_arquivo_pdf/claudia_reis.pdf $>$. Acesso em: 25 dez. 2009.

CUNHA, Luiz Alexandre Gonçalves. Sobre o conceito de região. Revista de História Regional, Ponta Grossa, v. 5, n. 2, p. 39-56, 2000. Disponível em: $<$ http://www.revistas.uepg.br/index.php?journal=rhr\&page=article\&op=view\&path[] $=157>$. Acesso em: 15 dez. 2010.

DAMATTA, Roberto. Você tem cultura? Jornal da Embratel, Rio de Janeiro, 1981.

Disponível em: $<$ http://www.furb.br/2005/arquivos/788660-

650601/voce\%20tem\%20cultura.pdf>. Acesso em: 08 jan. 2010.

DAVALLON, Jean. A mediação: a comunicação em processo? Prisma.com: revista de Ciências da Informação e da Comunicação, Porto, n. 4, jun. 2007. Disponível em: < http://prisma.cetac.up.pt/A_mediacao_a_comunicacao_em_processo.pdf $>$. Acesso em: 20 jun. 2009.

DEL PICCHIA, Paulo Menotti. Juca Mulato. Belo Horizonte: Editora Itatiaia, 1982.

DEMO, Pedro. Elementos metodológicos da pesquisa participante. In: BRANDÃO, Carlos Rodrigues (Org.). Repensando a pesquisa participante. 3. ed. São Paulo: Brasiliense, 2001. p. 104-130.

DICKS, Bella. Encoding and decoding the people: circuits of communication at a local heritage museum. European Journal of Communication, v. 15, n. 1, p. 61-78, 2000. Disponível em: < http://ejc.sagepub.com/content/15/1/61>. Acesso em: 12 ago. 2010.

DODEBEI, Vera. Construindo o conceito de documento. In: LEMOS, Teresa; MORAES, Nilson (Orgs.). Memória e construções de identidades. Rio de Janeiro: 7 Letras, 2000. p.59-66. 
DOIN, José Evaldo de Mello et al. A Belle Époque caipira: problematizações e oportunidades interpretativas da modernidade e urbanização no Mundo do Café (1852-1930) - a proposta do Cemunc. Revista Brasileira de História, São Paulo, v.27, n.53, p.91-122, 2007. Disponível em: $<$ http://www.scielo.br/scielo.php?script=sci_arttext\&pid=S0102-

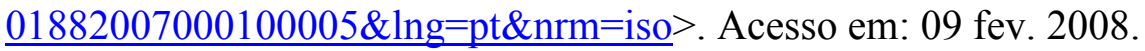

DUMAZEDIER, Joffre. Lazer e cultura popular. 3. ed. São Paulo: Perspectiva, 2001.

DURHAM, Eunice Ribeiro. Cultura, patrimônio e preservação (Texto II). In: ARANTES, Antônio Augusto (Org.). Produzindo o passado: estratégias de construção do patrimônio cultural. São Paulo: Brasiliense, 1984. p. 23-58.

DUVEEN, Gerard. Introdução: o poder das idéias. In: MOSCOVICI, Serge. Representações sociais: investigações em psicologia social. 6. ed. Petrópolis, RJ: Vozes, 2009. p. 7-28.

ELMIR, Cláudio Pereira. O que a micro-história tem a nos dizer sobre o regional e o local? (Comentários a Núncia Constantino, Regina Weber e Sandra Pesavento). História Unisinos, São Leopoldo, v. 8, n. 10, p. 191-205, jul./dez. 2004. Disponível em: < http://www.unisinos.br/publicacoes_cientificas/images/stories/sumario historia/vol10n8/19hi storian10vol8 artigo13.pdf $>$. Acesso em: 12 dez. 2010.

FARIA, Rodrigo Santos de. Ribeirão Preto, uma modernidade Entre Rios: higiene, beleza e progresso no discurso da metrópole do interior paulista (1902-1930). Revista Risco, v.4, n.2, p.36-50, 2006. Disponível em: < $<$ http://www.risco.eesc.usp.br/Risco4 pdf/art 5 risco4.pdf $>$. Acesso em: 29 dez. 2007.

FOLLIS, Fransérgio. Modernização urbana na Belle Époque paulista. São Paulo: Editora Unesp, 2004.

FONSECA, Maria Cecília Londres. O patrimônio em processo: trajetória da política federal de preservação no Brasil. 2. ed. rev. e ampl. Rio de Janeiro: Editora UFRJ; MinC - IPHAN, 2005.

Para além da pedra e cal: para uma concepção ampla de patrimônio cultural. In:

ABREU, Regina; CHAGAS, Mário (Orgs.). Memória e patrimônio: ensaios contemporâneos. Rio de Janeiro: DP\&A, 2003. p. 56-76.

. The registry of intangible heritage: the Brazilian experience. Museum

International: Intangible Heritage, Paris (UNESCO), v. 56, n. 1-2, p. 166-172, 2004.

Disponível em: < http://unesdoc.unesco.org/images/0013/001358/135852e.pdf\#135853>. Acesso em: 13 set. 2010.

FREIRE, Cristina. Além dos mapas: os monumentos no imaginário urbano contemporâneo. São Paulo: SESC; Annablume, 1997.

FROHMANN, Bernd. Documentation redux: prolegomenon to (another) philosophy of information. Library Trends, v. 52, n. 3, p. 387-407, 2004. Disponível em: < 
https://www.ideals.illinois.edu/bitstream/handle/2142/1683/Frohmann387407.pdf?sequence= $\underline{2}>$. Acesso em: 21 set. 2010.

O caráter social, material e público da informação. In: FUJITA, Mariângela Spotti Lopes; MARTELETO, Regina Maria; LARA, Marilda Lopes Ginez de (Orgs.). A dimensão epistemológica da Ciência da Informação e suas interfaces técnicas, políticas e institucionais nos processos de produção, acesso e disseminação da informação. Marília: Cultura Acadêmica; FUNDEPE, 2008. p. 19-34.

FUNDAÇÃO CULTURAL DE SANTA ROSA DE VITERBO. Histórico da Fundação Cultural de Santa Rosa de Viterbo. c2008. Disponível em: < http://www.bandasinfonicasrv.com/fundacao/historico.php >. Acesso em: 26 fev. 2009.

GABARRÓN, Luis R.; LANDA, Libertad Hernandez. O que é pesquisa participante. In: BRANDÃO, Carlos Rodrigues; STRECK, Danilo Romeu (Orgs.). Pesquisa participante: o saber da partilha. Aparecida: Idéias \& Letras, 2006. p. 93-121.

GARCÍA CANCLINI, Néstor. Culturas híbridas: estratégias para entrar e sair da modernidade. São Paulo: EDUSP, 1998.

Diferentes, desiguais e desconectados: mapas de interculturalidade. 2. ed. Rio de Janeiro: Editora UFRJ, 2007.

GEERTZ, Clifford. A interpretação das culturas. Rio de Janeiro: LTC, 2008.

GINZBURG, Carlo. Mitos, emblemas, sinais: morfologia e história. 2. ed. São Paulo: Companhia das Letras, 2002b.

O queijo e os vermes: o cotidiano e as idéias de um moleiro perseguido pela Inquisição. São Paulo: Companhia das Letras, 2009. 2002a.

Relações de força: história, retórica, prova. São Paulo: Companhia das Letras,

GONÇALVES, Cristiane Souza. Restauração arquitetônica: a experiência do SPHAN em São Paulo, 1937-1975. São Paulo: Annablume; FAPESP, 2007.

GONÇALVES, José Reginaldo S. Antropologia dos objetos: coleções, museus e patrimônios. Rio de Janeiro: IPHAN, 2007.

A retórica da perda: os discursos do patrimônio cultural no Brasil. 2. ed. Rio de Janeiro: Editora UFRJ; IPHAN, 2002.

O patrimônio como categoria de pensamento. In: ABREU, Regina; CHAGAS, Mário (Orgs.). Memória e patrimônio: ensaios contemporâneos. Rio de Janeiro: DP\&A, 2003. p. 21-29. 
GONDAR, Jô. Lembrar e esquecer: desejo de memória. In: COSTA, Icléia Thiesen M.; GONDAR, Jô (Orgs.). Memória e espaço. Rio de Janeiro: 7 Letras, 2000. p. 35-43.

GONDAR, Jô; DODEBEI, Vera (Orgs.). O que é memória social? Rio de Janeiro: Contra Capa, 2005.

GRENDI, Edoardo. Paradoxos da história contemporânea. In: OLIVEIRA, Mônica Ribeiro de. Exercícios de micro-história. Rio de Janeiro: Editora FGV, 2009. p. 39-49.

HALBWACHS, Maurice. A memória coletiva. São Paulo. Centauro, 2004.

HALL, Stuart. Reflexões sobre o modelo codificação/decodificação: uma entrevista com Stuart Hall. In: __ Da diáspora: identidades e mediações culturais. Belo Horizonte: Editora UFMG, 2009. p. 333-364.

. Codificação/decodificação. In: Da diáspora: identidades e mediações culturais. Belo Horizonte: Editora UFMG, 2009. p. 365-381.

HANDLER, Richard. On sociocultural discontinuity: nationalism and cultural objetification in Quebec. Current Anthropology, v. 25, n. 1, p. 55-71, fev. 1984. Disponível em: < http://www.jstor.org/pss/2742940>. Acesso em: 29 maio 2010.

HARTOG, François. Tempo e patrimônio. Varia história, Belo Horizonte, v. 22, n. 36, p. 261-273, jul./dez. 2006. Disponível em: < http://www.scielo.br/pdf/vh/v22n36/v22n36a02.pdf >. Acesso em: 14 fev. 2010.

HOBSBAWN, Eric; RANGER, Terence (Orgs.). A invenção das tradições. 5. ed. São Paulo: Paz e Terra, 2008.

HOLZER, Werther. O lugar na geografia humanista. Revista Território, Rio de Janeiro, ano 4, n. 7, p. 67-78, jul./dez. 1999. Disponível em:

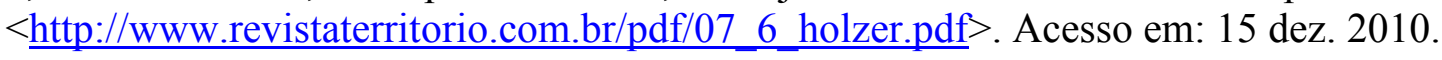

IBGE. Censo demográfico e contagem da população 2007. Rio de Janeiro, 2007.

Disponível em:

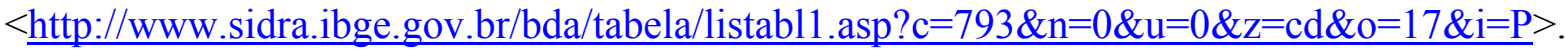
Acesso em: 12 set. 2009.

ICOMOS (CONSELHO INTERNACIONAL DE MONUMENTOS E SÍTIOS). Carta de Veneza, de maio de 1964. Veneza, 1964. Disponível em: < http://portal.iphan.gov.br/portal/baixaFcdAnexo.do?id=236>. Acesso em: 08 set. 2010.

INSTITUTO DO PATRIMÔNIO HISTÓRICO E ARTÍSTICO NACIONAL (IPHAN). Carta de Fortaleza. Fortaleza, 14 nov. 1997. Disponível em: < http://portal.iphan.gov.br/portal/baixaFcdAnexo.do?id=268>. Acesso em: 17 dez. 2008.

KIRSHENBLATT-GIMBLETT, Barbara. Intangible heritage as metacultural production. Museum International: Intangible Heritage, Paris (UNESCO), v. 56, n. 1-2, p. 52-64, 2004. 
Disponível em: < http://unesdoc.unesco.org/images/0013/001358/135852e.pdf\#135853>. Acesso em: 13 set. 2010.

KURIN, Richard. Safeguarding intangible cultural heritage in the 2003 UNESCO Convention: a critical appraisal. Museum International: Intangible Heritage, Paris (UNESCO), v. 56, n. 1-2, p. 66-76, 2004. Disponível em: < http://unesdoc.unesco.org/images/0013/001358/135852e.pdf\#135853 >. Acesso em: 13 set. 2010.

LAFETÁ, João Luiz. 1930: a crítica e o modernismo. 2. ed. São Paulo: Duas Cidades; Editora $34,2000$.

LANDSBERG, Alison. Prosthetic memory: the transformation of American remembrance in the age of mass culture. New York: Columbia University Press, 2004.

LATOUR, Bruno. Redes que a razão desconhece: laboratórios, bibliotecas, coleções. In:

BARATIN, Marc; JACOB, Christian (Orgs.). O poder das bibliotecas: a memória dos livros no Ocidente. Rio de Janeiro: Editora UFRJ, 2000. p. 21-44.

LE COADIC, Yves-François. A ciência da informação. 2. ed. rev. e atual. Brasília: Briquet de Lemos, 2004.

LE GOFF, Jacques. História e memória. 5. ed. Campinas: Editora da Unicamp, 2003.

LEITE, Rogério Proença. Contra-usos da cidade: lugares e espaço público na experiência contemporânea. 2. ed. rev. e ampl. Campinas: Editora da UNICAMP; Aracaju: Editora UFS, 2007.

LEITE, Sylvia Helena T. de A. Chapéus de palha, panamás, plumas, cartolas: a caricatura na literatura paulista (1900-1920). São Paulo: Editora UNESP, 1996.

LEPETIT, Bernard. Il concetto di scala in storia. In: REVEL, Jacques (Org.). Giochi di scala: la microstoria alla prova dell'esperienza. Roma: Viella, 2006. p. 85-112.

LEVI, Giovanni. Prefácio. In: OLIVEIRA, Mônica Ribeiro de. Exercícios de micro-história. Rio de Janeiro: Editora FGV, 2009. p. 11-16.

LEVY, Pierre. Cibercultura. São Paulo: Editora 34, 1999.

LIMA, Henrique Espada. Narrar, pensar o detalhe: à margem de um projeto de Carlo Ginzburg. ArtCultura: Revista de História, Uberlândia, v. 9, n. 15, p. 100-111, jul./dez. 2007. Disponível em:

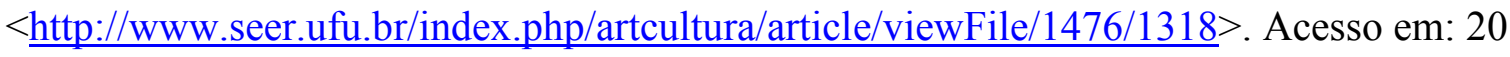
mar. 2010.

LOBATO, Monteiro. Cidades mortas. São Paulo: Globo, 2007.

Idéias de Jeca tatu. São Paulo: Globo, 2008. 
Urupês. 13 ed. São Paulo: Editora Brasiliense, 1964.

LOSNAK, Célio José. Polifonia urbana: imagens e representações: Bauru 1950-1980. Bauru: Edusc, 2004.

LUYTEN, Joseph M. Desafio e repentismo do caipira de São Paulo. In: BOSI, Alfredo (Org.). Cultura brasileira: temas e situações. São Paulo: Editora Ática, 1987. p.75-102.

MAGNANI, José G. C. Santana do Parnaíba: memória e cotidiano. NAU - Núcleo de Antropologia Urbana da USP, São Paulo, 2007. Disponível em: $<$ http://www.n-au.org/magnanisantanadoparnaibav2.html >. Acesso em: 26 set. 2009.

MARKOWITSCH, Hans J. Pré-requisitos emocionais e cognitivos da memória autobiográfica. In: GALLE, Helmut et. al. (Orgs.). Em primeira pessoa: abordagens de uma teoria da autobiografia. São Paulo: Annablume; FAPESP; FFLCH, USP, 2009. p. 63-78.

MARTÍN-BARBERO, Jesús. Dos meios às mediações: comunicação, cultura e hegemonia. Rio de Janeiro: Editora UFRJ, 1997.

MEIHY, José Carlos Sebe B.; HOLANDA, Fabíola. História oral: como fazer, como pensar. São Paulo: Contexto, 2007.

MEINERZ, Andréia. Concepção de experiência em Walter Benjamin. 2008. 81 f.

Dissertação (Mestrado em Filosofia)-Instituto de Filosofia e Ciências Humanas, Universidade Federal do Rio Grande do Sul, Porto Alegre, 2008.

MISZTAL, Barbara. Memory experience: the forms and functions of memory. In: WATSON, Sheila (Org.). Museums and their communities. London; New York: Routledge, 2007. p. 379-396.

MENESES, Ulpiano T. Bezerra de. A crise da memória, história e documento: reflexões para um tempo de transformações. In: SILVA, Zélia Lopes da (Org.). Arquivos, patrimônio e memória: trajetórias e perspectivas. São Paulo: Editora Unesp; FAPESP, 1999. p. 11-29.

Do teatro da memória ao laboratório da história: a exposição museológica e o conhecimento histórico. Anais do Museu Paulista: história e cultura material, São Paulo, v.2, p.9-42, jan./dez. 1994.

MONNET, Jérome. O álibi do patrimônio: crise da cidade, gestão urbana e nostalgia do passado. Revista do Patrimônio Histórico e Artístico Nacional: Cidadania, Rio de Janeiro, n. 24, p.220-228, 1996.

NEEDELL, Jeffrey D. Belle Époque tropical: sociedade e cultura de elite no Rio de Janeiro na virada do século. São Paulo: Companhia das Letras, 1993.

NEVES, Erivaldo Fagundes. História e região: tópicos de história regional e local. Ponta de Lança: revista eletrônica de história, memória e cultura, São Cristóvão, v. 1, n. 2, abr./out., p. 
25-36,

2008.

Disponível

em:

http://www.posgrap.ufs.br/periodicos/ponta de lanca/revistas/Ponta de lanca v01 n02 com pleta.pdf $>$. Acesso em: 14 dez. 2010.

NOGUEIRA, Antônio Gilberto Ramos. Por um inventário dos sentidos: Mário de Andrade e a concepção de patrimônio e inventário. São Paulo: Hucitec; FAPESP, 2005. (Estudos brasileiros; 39).

OLIVEN, Ruben George, Patrimônio intangível: considerações iniciais. In: ABREU, Regina; CHAGAS, Mário (Orgs.). Memória e patrimônio: ensaios contemporâneos. Rio de Janeiro: DP\&A, 2003. p. 77-80.

ORTEGA, Cristina Dotta; LARA, Marilda Lopes Ginez de. A noção de documento: de Otlet aos dias de hoje. DataGramaZero: Revista de Ciência da Informação, v. 11, n. 2, abr. 2010. Não paginado. Disponível em: < http://dgz.org.br/abr10/F_I art.htm>. Acesso em: 20 set. 2010 .

OTLET, Paul. El tratado de documentación: el libro sobre el libro: teoria y prática. Murcia: Universidad de Murcia, 1996.

PALMÉRIO, Mário. Vila dos Confins. São Paulo: Abril Cultural, 1983.

PERROTTI, Edmir; PIERUCCINI, Ivete. Infoeducação: saberes e fazeres da contemporaneidade. In: LARA, Marilda Lopes G. de; FUJINO, Asa; NORONHA, Daisy Pires (Orgs.). Informação e contemporaneidade: perspectivas. Recife: NÉCTAR, 2007. p. 47-96.

PESAVENTO, Sandra Jatahy. Cidades visíveis, cidades sensíveis, cidades imaginárias.

Revista Brasileira de História, São Paulo, v. 27, n. 53, p. 11-23, 2007. Disponível em: < http://www.scielo.br/pdf/rbh/v27n53/a02v5327.pdf $>$. Acesso em 14 jan. 2010.

PIERUCCINI, Ivete. Ordem informacional dialógica: mediação como apropriação da informação. In: ENCONTRO NACIONAL DE PESQUISA EM CIÊNCIA DA INFORMAÇÃO, 8., 2007, Salvador. Anais eletrônicos... Salvador: ENANCIB, 2007. Disponível em: < http://www.enancib.ppgci.ufba.br/artigos/GT3--159.pdf $>$. Acesso em: 03 ago. 2008. Não Paginado.

POE, Edgar Allan. O escaravelho de ouro. In: Histórias extraordinárias. São Paulo: Abril Cultural. 1978. p. 333-377.

POLLAK, Michael. Memória, esquecimento, silêncio. Estudos Históricos, Rio de Janeiro, v. 2, n. 3, p. 3-15, 1989. Disponível em: < http://www2.uel.br/cch/cdph/arqtxt/Memoria_esquecimento_silencio.pdf $>$. Acesso em 30 dez. 2009.

PORTELLI, Alessandro (Coord.). República dos sciuscià: a Roma do pós-guerra na memória dos meninos de Dom Bosco. São Paulo: Editora Salesiana, 2004. 
PORTELLI, Alessandro. A Filosofia e os fatos: narração, interpretação e significado nas memórias e nas fontes orais. Tempo, Rio de Janeiro, v. 1, n. 2, p. 59-72, 1996. Disponível em: < http://www.historia.uff.br/tempo/artigos_dossie/artg2-3.pdf $>$. Acesso em: 1 jul. 2009.

O massacre de Civitella Val di Chiana (Toscana, 29 de junho de 1944): mito e política, luto e senso comum. In: FERREIRA, Marieta de Moraes; AMADO, Janaína (Orgs.). Usos \& abusos da história oral. 2. ed. Rio de Janeiro: Fundação Getúlio Vargas, 1998. p. 103-130.

PROUST, Marcel. No caminho de Swann. 3. ed. rev. São Paulo: Globo, 2007. (Em busca do tempo perdido; v. 1).

QUEIROZ, Renato da Silva. Caipiras negros no Vale do Ribeira: um estudo de antropologia econômica. 2. ed. São Paulo: Editora da Universidade de São Paulo, 2006.

RIBEIRÃO PRETO. Lei Ordinária n ${ }^{\circ}$ 2508, de 21 de setembro de 1971. Cria o Conselho de Defesa do Patrimônio Histórico e Cultural do Município. Ribeirão Preto, c2004. Disponível em: $\leq$ http://www.ribeiraopreto.sp.gov.br/principal.asp?pagina=/leis/pesquisa/pesquisa.php $>$. Acesso em: 29 dez. 2007.

RICOEUR, Paul. A memória, a história, o esquecimento. Campinas: Editora da Unicamp, 2010.

RIEGL, Alois. Il culto moderno dei monumenti: il suo carattere e i suoi inizi. 3. ed. Bologna: Nuova Alfa Editoriale, 1990.

ROSENZWEIG, Roy; THELEN, David. The presence of the past: popular uses of history in american life. New York: Columbia University Press, 1998.

ROSSINI, Rosa Ester; OLIVEIRA, Raimunda Maria de. Sociedade e natureza. In: BACELLAR, Carlos de Almeida Prado; BRIOSCHI, Lucila Reis (Orgs.). Na estrada do Anhanguera: uma visão regional da história paulista. São Paulo: Humanitas: FFLCH/USP, 1999. p. 23-33.

ROUVEROL, Alicia J. Collaborative oral history in a correctional setting: promisse and pitfalls. The Oral History Review, Berkeley, v. 30, n. 1, p. 61-85, 2003. Disponível em: $<$ http://www.jstor.org/stable/3675352>. Acesso em: 14 mar. 2010.

SAHLINS, Marshall. O "pessimismo sentimental" e a experiência etnográfica: por que a cultura não é um "objeto" em via de extinção (parte II). Mana, Rio de Janeiro, v. 3, n. 2, out. 1997a. Disponível em

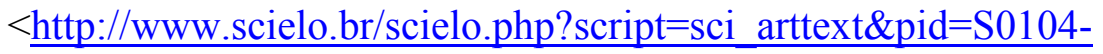
93131997000200004\&lng=pt\&nrm=iso $>$. Acesso em: 12 set. 2009.

O "pessimismo sentimental" e a experiência etnográfica: por que a cultura não é um "objeto" em via de extinção (parte I). Mana, Rio de Janeiro, v. 3, n. 1, abr. 1997b. Disponível em 
$<$ http://www.scielo.br/scielo.php?script=sci_arttext\&pid=S0104-

93131997000100002\&lng=pt\&nrm=iso $>$. Acesso em: 12 set. 2009.

SANT'ANNA, Márcia. A face imaterial do patrimônio cultural: os novos instrumentos de reconhecimento e valorização. In: ABREU, Regina; CHAGAS, Mário (Orgs.). Memória e patrimônio: ensaios contemporâneos. Rio de Janeiro: DP\&A, 2003. p. 46-55.

SANTA ROSA DE VITERBO. Banda Sinfônica. Um grande salto via Lei Roaunet. c2009.

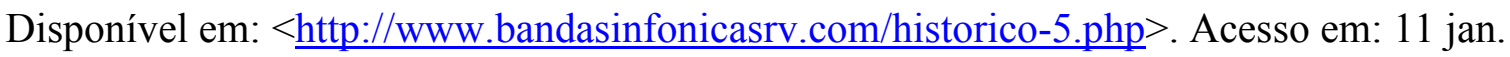
2010 .

Fundação cultural. Relatório de atividades culturais [ano base 2007]. Santa Rosa de Viterbo, 2008. p.1-5.

. Lei $n^{\circ} 3054$, de 9 novembro de 2006. Dispõe sobre a criação do Conselho Municipal de Preservação do Patrimônio Histórico, Artístico, Paisagístico e Cultural de Santa Rosa de Viterbo, e dá outras providências. Disponível em: < http://www.bandasinfonicasrv.com/leidecriacao.php>. Acesso em: 28 ago. 2008.

Município de Santa Rosa. Santa Rosa de Viterbo, [1939?].

SANTOS, Carlos José F. dos. Identidade urbana e globalização: a formação dos múltiplos territórios em Grarulhos/SP. São Paulo: Annablume; Guarulhos: Sindicato dos Professores de Guaruhos, 2006.

SANTOS, Fábio Alexandre dos. Rio Claro: uma cidade em transformação, 1850 - 1906. 2000. 202f. Dissertação (Mestrado em História Econômica)-Instituto de Economia, Universidade de Campinas, Campinas, 2000.

SANTOS, Maria Célia Teixeira Moura. Reflexões sobre a Nova Museologia. In: Encontros museológicos: reflexões sobre a museologia, a educação e o museu. Rio de Janeiro: Minc/IPHAN/DEMU, 2008. p. 69-98.

SANTOS, Myrian Sepúlveda dos. Memória coletiva \& teoria social. São Paulo: Annablume, 2009.

O pesadelo da amnésia coletiva: um estudo sobre os conceitos de memória, tradição e traços do passado. Cadernos de Sociomuseologia: museus e políticas de memória, n. 19, p. 121-150, 2002. Disponível em: < http://revistas.ulusofona.pt/index.php/cadernosociomuseologia/article/viewFile/370/279 >. Acesso em: 1 jul. 2009.

SÃO PAULO (Estado). Fundação SEADE. Informações dos municípios paulistas - IMP. São Paulo, c2007. Disponível em:

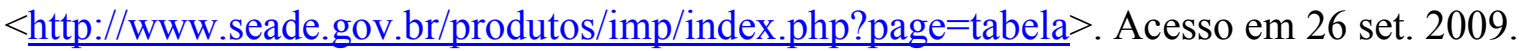


. Fundação SEADE. Produto Interno Bruto - PIB Municipal (2006). São Paulo, 2009. Disponível em: < http://www.seade.gov.br/produtos/pibmun/index.php $>$. Acesso em: 12 set. 2009.

SEVCENKO, Nicolau. Literatura como missão: tensões sociais e criação cultural na Primeira República. 2. ed. rev. e ampl. São Paulo: Companhia das Letras, 2003.

SILVA, Amando. Imaginários urbanos. São Paulo: Perspectiva; Bogotá: Convenio Andres Bello, 2001.

SILVA, André Eduardo Ribeiro da. A territorialização da agroindústria sucroalcooleira: o processo de reestruturação produtiva no campo e os trabalhadores canavieiros da fazenda Amália/ SP. 2007. 200f. Dissertação (Mestrado em Geografia Humana)-Faculdade de Filosofia, Letras e Ciências Humanas, Universidade de São Paulo, São Paulo, 2007. Disponível em: < http://www.teses.usp.br/teses/disponiveis/8/8136/tde-16102007-114458/ptbr.php >. Acesso em: 2 nov. 2010.

SILVA, Joseli Maria. Cultura e territorialidades urbanas: uma abordagem da pequena cidade. Revista de História Regional, Ponta Grossa, v. 5, n. 2, p. 9-37, 2000. Disponível em: $<\underline{\text { http://www.revistas.uepg.br/index.php?journal=rhr\&page }=\text { article\&op=view\&path[] }=156>}$. Acesso em: 14 dez. 2010.

SILVA, Maria Aparecida de Moraes. A cultura na esteira do tempo. São Paulo em Perspectiva, São Paulo, v.15, n.3, p. 102-112, jul. 2001. Disponível em:

$<\underline{\text { http://www.scielo.br/scielo.php?script }=\text { sci_arttext\&pid }=\text { S0102- }}$

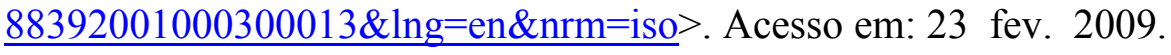

SILVERSTONE, Roger. Por que estudar a mídia? São Paulo: Edições Loyola, 2002.

SMITH, Laurajane. Uses of heritage. London; New York: Routledge, 2008.

SOMMER, Robert; AMICK, Terrence. Pesquisa-ação: ligando pesquisa à mudança organizacional. In: GÜNTHER, Hartmut (Org.). Planejamento de pesquisa para as Ciências Sociais. Brasília, DF: UnB; Laboratório de Psicologia Ambiental, 2003. p. 1-18, n.

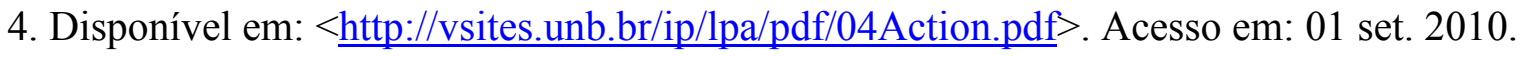

STRAUB, Jürgen. Memória autobiográfica e identidade pessoal. Considerações históricoculturais, comparativas e sistemáticas sob a ótica da psicologia narrativa. In: GALLE, Helmut et. al. (Orgs.). Em primeira pessoa: abordagens de uma teoria da autobiografia. São Paulo: Annablume; FAPESP; FFLCH, USP, 2009. p. 79-98.

THIOLLENT, Michel. Notas para o debate sobre pesquisa-ação. In: BRANDÃO, Carlos Rodrigues (Org.). Repensando a pesquisa participante. 3. ed. São Paulo: Brasiliense, 2001. p. 82-103.

THOMPSON, Paul. A voz do passado: história oral. 3. ed. São Paulo: Paz e Terra, 2002. 
TOURTIER-BONAZZI, Chantal de. Arquivos: propostas metodológicas. In: FERREIRA, Marieta de Moraes; AMADO, Janaína (Orgs.). Usos \& abusos da história oral. 2. ed. Rio de Janeiro: Fundação Getúlio Vargas, 1998. p. 233-245.

TRIPP, David. Pesquisa-ação: uma introdução metodológica. Educação e Pesquisa, São Paulo, v. 31, n. 3, p. 443-466, set./dez. 2005. Disponível em: <

http://www.scielo.br/pdf/ep/v31n3/a09v31n3.pdf > . Acesso em 01 set. 2010.

UNESCO. Convenção sobre a Proteção e Promoção da Diversidade das Expressões Culturais, de 20 de outubro de 2005. Paris, 2005. Disponível em: <

http://unesdoc.unesco.org/images/0015/001502/150224por.pdf > . Acesso em: 12 set. 2010.

Recomendação de Paris - Convenção para a Salvaguarda do Patrimônio Cultural

Imaterial, de 17 de outubro de 2003. Paris, 2003. Disponível em: <

http://portal.iphan.gov.br/portal/baixaFcdAnexo.do?id=271>. Acesso em: 08 set. 2010.

Recomendação de Paris - Proteção do Patrimônio Mundial, Cultural e Natural, de 16 de novembro de 1972. Paris, 1972. Disponível em: <

http://portal.iphan.gov.br/portal/baixaFcdAnexo.do?id=244>. Acesso em: 08 set. 2010.

. Recomendação de Paris - Recomendação sobre a Salvaguarda da Cultura Popular e

Tradicional, de 15 de novembro de 1989. Paris, 1989. Disponível em: <

http://portal.iphan.gov.br/portal/baixaFcdAnexo.do?id=261>. Acesso em: 08 set. 2010.

UNIVERSIDADE PAULISTA. Plano de desenvolvimento turístico do município de Santa Rosa de Viterbo. Ribeirão Preto, 2002.

VELHO, Gilberto. Patrimônio, negociação e conflito. Mana, Rio de Janeiro, v. 12, n. 1, abr. 2006. Disponível em: $\quad<$ http://www.scielo.br/scielo.php?script=sci arttext\&pid=S010493132006000100009\&lng=pt\&nrm=iso $>$. Acesso em: 17 dez. 2008.

VELLOSO, Mônica P. A brasilidade verde-amarela: nacionalismo e regionalismo paulista.

Estudos Históricos, Rio de Janeiro, v. 6. n. 11. p. 89-112, 1993. Disponível em: < http://www.casaruibarbosa.gov.br/dados/DOC/artigos/o-

z/FCRB_MonicaVeloso_Brasilidade_verde_amarela.pdf>. Acesso em: 23 fev. 2009.

VEYNE, Paul. Como se escreve a história e Foucault revoluciona a história. 4. ed. rev. Brasília: Editora Universidade de Brasília, 2008.

WEBER, Max. A dominação não legítima (tipologia das cidades). In: Economia e sociedade: fundamentos da sociologia compreensiva. Brasília: Editora da UnB, 1999. p. 408517. (v. 2).

WHYTE, William Foote. Advancing scientific knowledge through participatory research. Sociological Forum, v. 4, n. 3, p. 367-385, Sept. 1989. Disponível em: < http://www.jstor.org/stable/684609>. Acesso em: 21 Aug. 2010.

WILLIAMS, Raymond. Cultura. 3. ed. São Paulo: Paz e Terra, 2008. 
Palavras-chave: um vocabulário de cultura e sociedade. São Paulo: Boitempo Editorial, 2007.

YATSUDA, Enid. A ficção movediça: uma leitura de Leréias, de Valdomiro Silveira. 1983. 172 f. Dissertação (Mestrado em Teoria Literária)-Instituto de Estudos da Linguagem, Universidade Estadual de Campinas, Campinas, 1983.

O caipira e os outros. In: BOSI, Alfredo (Org.). Cultura brasileira: temas e situações. São Paulo: Editora Ática, 1987. p.103-113. 